\title{
Site Synthesis Report of DSDP Sites 417 and 418
}

\author{
by
}

\author{
S.A. Swift, S.T. Bolmer, and R.A. Stephen \\ Woods Hole Oceanographic Institution \\ Woods Hole, Massachusetts 02543
}

June 1989

\section{Technical Report}

Funding was provided by the Johns Hopkins University, Applied Physics Laboratory under contract Number 602809-0.

Reproduction in whole or in part is permitted for any purpose of the

United States Government. This report should be cited as:

Woods Hole Oceanog. Inst. Tech. Rept., WHOI-89-20.

Approved for publication; distribution unlimited.

Approved for Distribution:

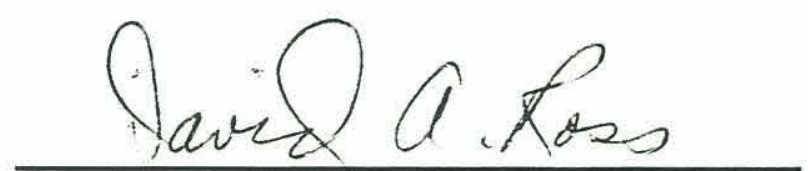

David A. Ross, Chairman

Department of Geology \& Geophysics 
3 


\section{SITE SYNTHESIS REPORT OF DSDP SITES 417 and 418}

S.A. Swift, S.T. Bolmer, and R.A. Stephen 
ᄃ 


\section{TABLE OF CONTENTS}

Introduction

$\underline{\text { Page }}$

General Information

Location

Age

Crustal Structure

Sedimentary Development

Geophysical Studies

Magnetics

Gravity

Heat Flow

Reflection Seismics

Refraction Seismics

Borehole Sediment Studies

Lithostratigraphy

Mineralogy and Chemistry

Micropaleontology

Physical Properties

Borehole Basement Studies $\quad 39$

Lithostratigraphy $\quad 39$

Mineralogy 46

Geochemistry $\quad 49$

Alteration $\quad 52$

Paleomagnetism and Rock Magnetism $\quad 60$

Physical Properties 66

$\begin{array}{ll}\text { Logging Studies } & 73\end{array}$

Hole 417D - DSDP Leg 51

Hole 418A - ODP Leg 102

Borehole Seismics Experiments 94

Data Stored in National Geophysical Data Center 103

Underway Geophysics $\quad 103$

$\begin{array}{ll}\text { Cores } & 129\end{array}$ 

$\underline{\text { Page }}$

Engineering Report

131

Cone Specifications

131

Operations Resumes

133

$\begin{array}{ll}\text { Seafloor Obstacles } & 138\end{array}$

DSDP Cones

138

Transponders

138

Drilling Gear

141

$\begin{array}{ll}\text { Physical Oceanography } & 145\end{array}$

Acknowledgements 146

References 149 


\section{INTRODUCTION}

This document was sponsored by the LFASE program, a borehole seismometer study of Deep Sea Drilling Program (DSDP) Site 418. This compilation was completed prior to LFASE sponsored cruises to Site 418 to assist scientists, engineers, and administrators in final planning of the experiment. We had four objectives: (1) describe basement rock, sediments, seafloor and ocean environment at Site 418, (2) provide a bibliography of published data on Site 418, (3) present previously unpublished scientific results from the borehole seismometer experiments conducted on DSDP leg 52 and Ocean Drilling Program (ODP) Leg 102, and (4) summarize knowledge on the condition of the reentry cone, bottom hole assembly, and hole.

The history of investigation at Site $417 / 418$ is short despite the concerted drilling effort during DSDP. JOIDES planned DSDP Leg 51 to drill ocean floor south of Bermuda near $30^{\circ} \mathrm{N}$. Delays in the D/V CHALLENGER schedule early in 1976 postponed Leg 51 departure to November. The JOIDES planning committee moved the site south by $500 \mathrm{nmi}$ to avoid poor weather. The first survey cruise, other than sporadic ship transits (charted in Rabinowitz et al., 1980), was made in September, 1976, by the USNS LYNCH (Hoskins and Groman, 1976). Underway geophysics data obtained on this cruise were used for site selection on DSDP Legs 51, 52, and 53 between November 1976, and April 1977 (Table 1; Donnelly et al., 1980). In May 1977, the R/V ROBERT D. CONRAD returned to Site 417 to do a bottom hydrophone survey (Bryan, 1980). The R/V ATLANTIS II visited Sites 417 and 418 in February, 1978, to conduct a more extensive bottom hydrophone survey (Purdy et al., 1980) and to measure heat flow (Galson and Von Herzen, 1981). Hole 418A was re-entered in March 1985 on ODP Leg 102 to make borehole geophysical measurements (Salisbury et al., 1986). Leg 102 did not attempt to drill in Hole 418A.

In drilling Sites $417 / 418$, JOIDES sought to establish a reentry hole which could be extended, by multiple drilling ship legs if necessary, through seismic layer 2 into layer 3 . The objective was to sample crust formed during the Cretaceous along a tectonic flow line 


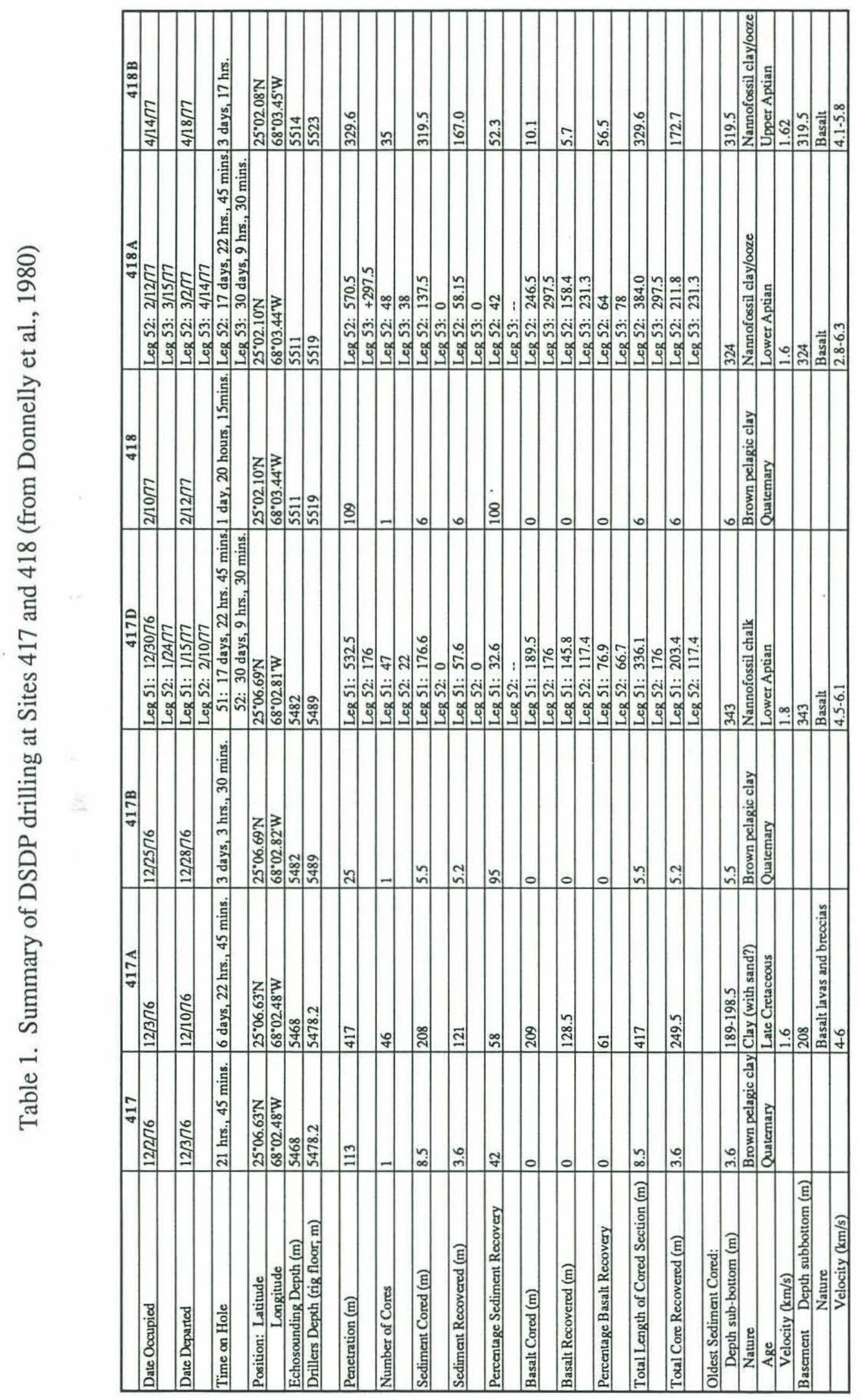


through boreholes already established on the mid-Atlantic Ridge. JOIDES targeted magnetic anomaly $\mathrm{M} 0$, the youngest anomaly bounding the Cretaceous magnetic quiet zone, in order to date the anomaly and to provide firm tectonic control (Figure 1). GENERAL INFORMATION

Location

Sites 417 and 418 are located in about $5500 \mathrm{~m}$ of water on the extreme southwestward edge of the Bermuda Rise just north of the Vema Gap connecting the Hatteras and Nares abyssal plains (Figure 2). Regionally, bathymetry varies up to $\pm 200 \mathrm{~m}$ due largely to changes in basement relief (Hoskins and Groman, 1976; Rabinowitz et al., 1980). Near the drill sites, the seafloor slopes gently westward (Senske and Stephen, 1988; Figure 3). Tectonically, Site 417 lies in the middle of the M0 magnetic block, whereas Site 418 lies on the eastern edge of the M0 block (Figure 1; 417 Site Report, Figure 4, and 418 Site Report, Figure 3, in Donnelly et al., 1980; Rabinowitz et al., 1980). $\underline{\text { Age }}$

Recent revisions to the geologic time scale have made the age of the crust at Sites 417 and 418 problematic. Clearly, the sites are located on magnetic anomaly M0 and the oldest sediments at both sites is Lower Aptian (Donnelly et al., 1980). Based on these data, the Larson and Hilde (1975) time scale gives an age of 108-110 Ma, whereas more recent time scales of Harland et al. (1982) and Kent and Gradstein (1985) increase the age by $\sim 10 \mathrm{Ma}$ to $118-120 \mathrm{Ma}$. This latter estimate conflicts with the best isotopic age estimates on basalt samples from 417 and 418 . Storzer and Selo (1980) used fission track dating on 17 basalt glass samples from Holes 417D and 418A to obtain an age of 108.3 \pm 1.3 Ma. Richardson et al. (1980) used Rb-Sr dating of vein-filling alteration minerals to obtain ages of $108 \pm 3 \mathrm{Ma}$ for Hole 417 A and $108 \pm 17 \mathrm{Ma}$ for Hole 418D. Two less well constrained dating methods gave a ${ }^{40} \mathrm{Ar}-{ }^{39} \mathrm{Ar}$ age of about $120 \mathrm{Ma}$ on one basalt sample from 417D (Ozima et al, 1980) and an age of $120 \pm 5 \mathrm{Ma}$ for 417A and 418A vein calcites 
Figure 1. Location of Sites 417 and 418 with respect to tectonic features of the western North Atlantic. Anomaly and fracture zone positions from Klitgord and Schouten (1986).

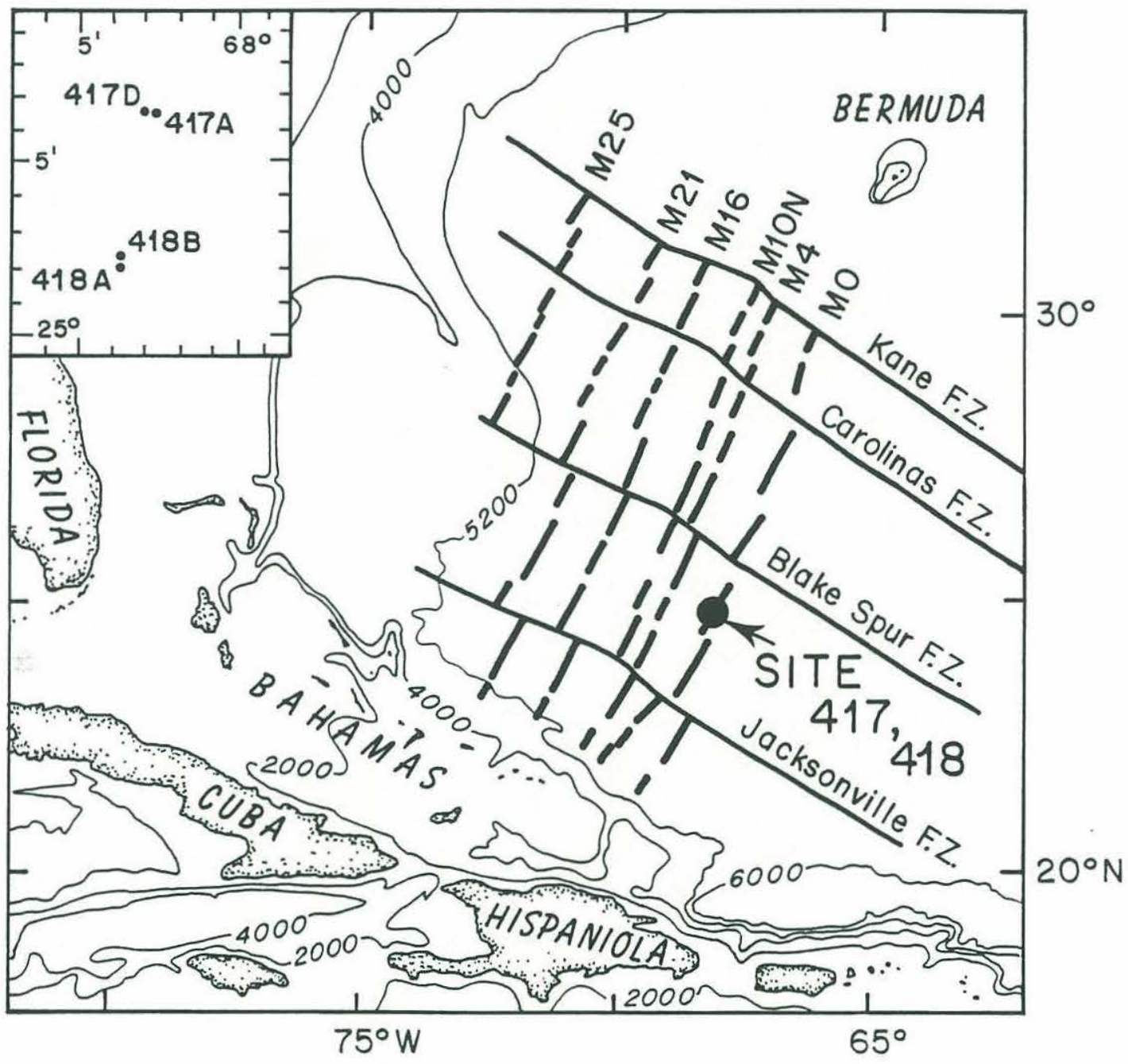


Figure 2. Location of Sites 417 and 418 with respect to physiographic provinces of Emery and Uchupi (1984). From Senske and Stephen (1988).

\section{PHYSIOGRAPHY}

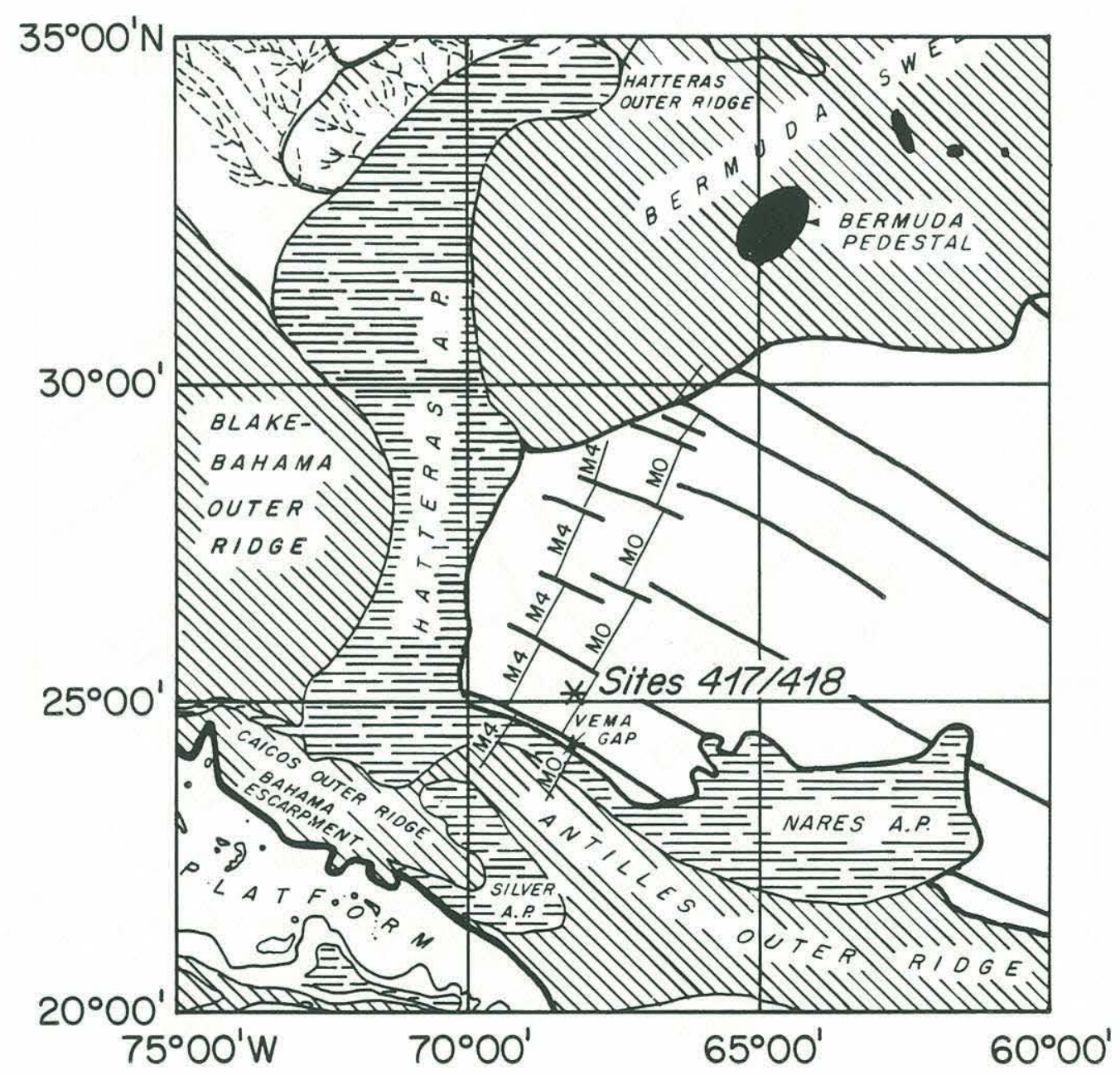


Figure 3. Bathymetry of Sites 417 and 418 compiled from well-navigated echo-sounding data:

Bathymetry of DSDP Sites 417 and 418

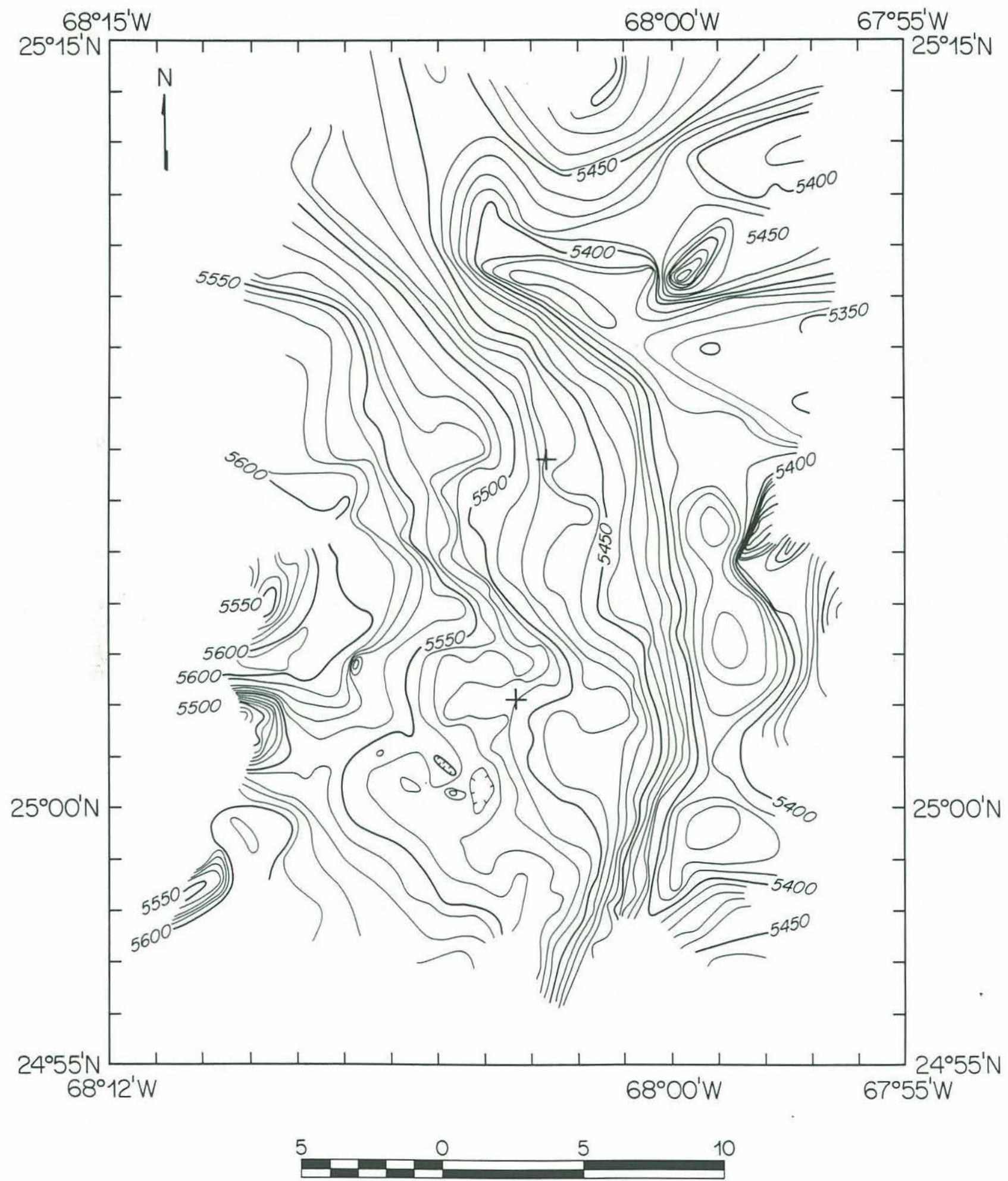


based on their ${ }^{87} \mathrm{Sr} /{ }^{66} \mathrm{Sr}$ ratio and variation in seawater strontium ratio with time (Richardson et al. 1980).

The paleo-spreading rate is less controversial because Kent and Gradstein (1985) applied a uniform timeshift to the early Mesozoic magnetic anomalies. Based on the LYNCH survey, M. Carle (in Hoskins and Groman, 1976) estimated the M0-M1 half-rate as $1.80 \pm 0.05 \mathrm{~cm} / \mathrm{yr}$ and the M0-M4 half-rate as $1.27 \pm 0.01 \mathrm{~cm} / \mathrm{yr}$. Magnetic anomalies strike $\sim \mathrm{N} 25^{\circ} \mathrm{E}$.

\section{Crustal Structure}

Most direct and indirect evidence indicates that sites 417 and 418 were drilled in ocean crust that is typical of Mesozoic crust in the North Atlantic (Flower and Robinson, 1981b). Galson and Von Herzen (1981) show that the range of basement depths near these sites brackets the depth-age curve derived by exponential approximation to the plate cooling model of Parsons and Sclater (1977). Figure 4 shows that upper crustal compressional wave velocities at Sites 417 and 418 do not differ significantly from a well-constrained refraction velocity profile obtained by Purdy (1983) on 140 Ma old crust in the western North Atlantic. Basaltic pillow lavas, massive flow units, and dikes sampled by drilling at Sites 417 and 418 are similar to rock sequences sampled by other deep drilling holes (Robinson et al., 1980; Flower and Robinson, 1981b; Bryan and Frey, 1986). A well constrained velocity profile (Figure 5) from expanding-spread profile (ESP) 5 shot on anomaly M0 (Figure 6) during the North Atlantic transect (NAT) indicates that crustal thickness $(7.8 \mathrm{~km})$ is similar to crustal thicknesses between fracture zones elsewhere along the NAT line and to $140 \mathrm{Ma}$ old crust in the western North Atlantic (NAT Study Group, 1985; Mutter et al., 1985; Mithal, 1986). This profile, however, indicates an $2.9 \mathrm{~km}$ thick low velocity zone at the base of layer 3 not observed in ESP data elsewhere along the NAT line or in more conventional refraction data (Figure 5; Purdy, 1983; White, 1984; Purdy and Ewing, 1986). At this time, it is uncertain whether the lower crust at ESP 5 is unusual 


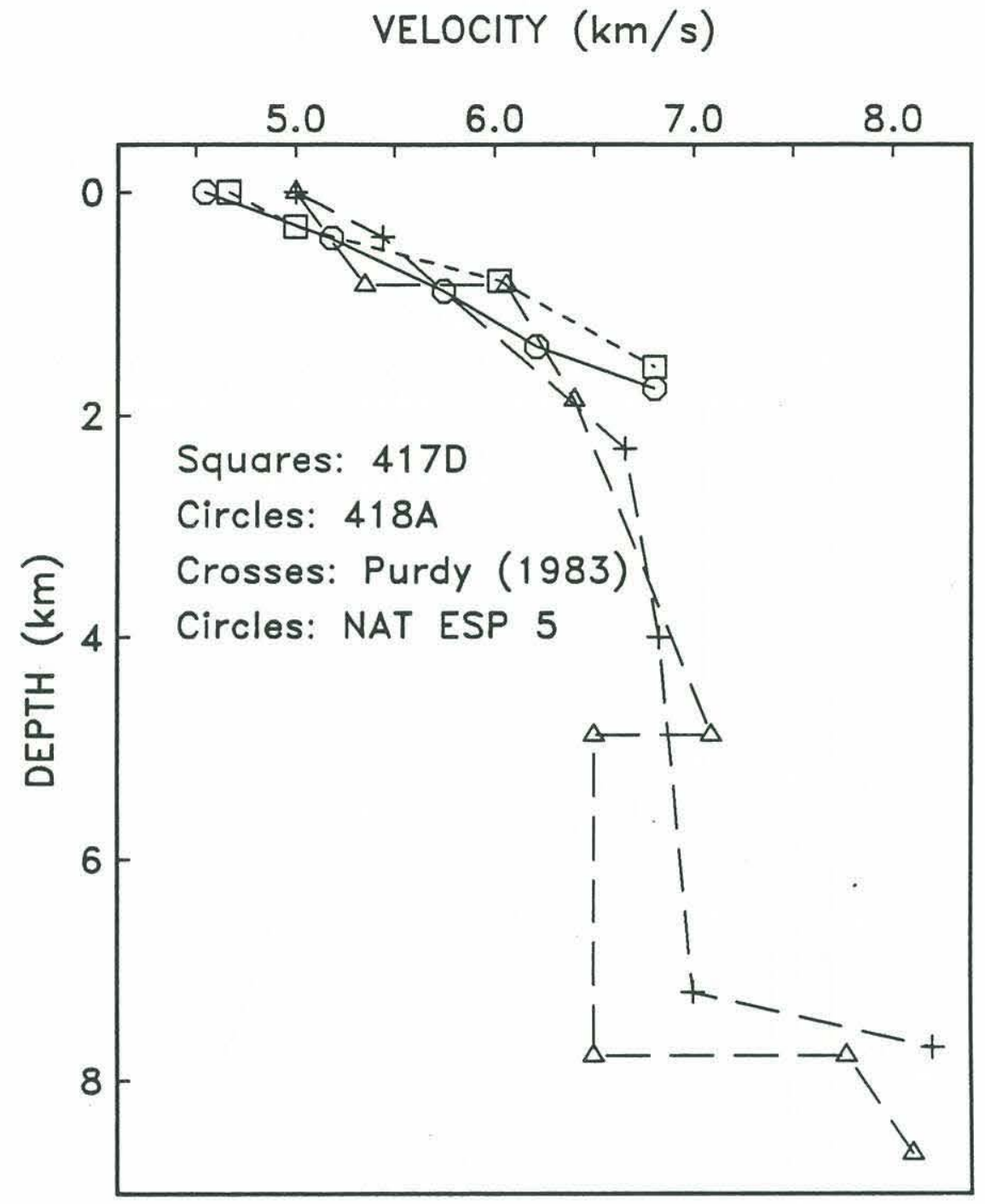

Figure 4. Compressional velocities form tau-zeta in version of oblique seismic experiment travel times for Holes 417D (Stephen and Harding, 1983) and 418A (Swift and Stephen, in press). Also shown are full crustal velocity profiles from ESP 5 of the NAT (Mithal, 1986) and from Purdy's (1983) study of 140 Ma crust. 


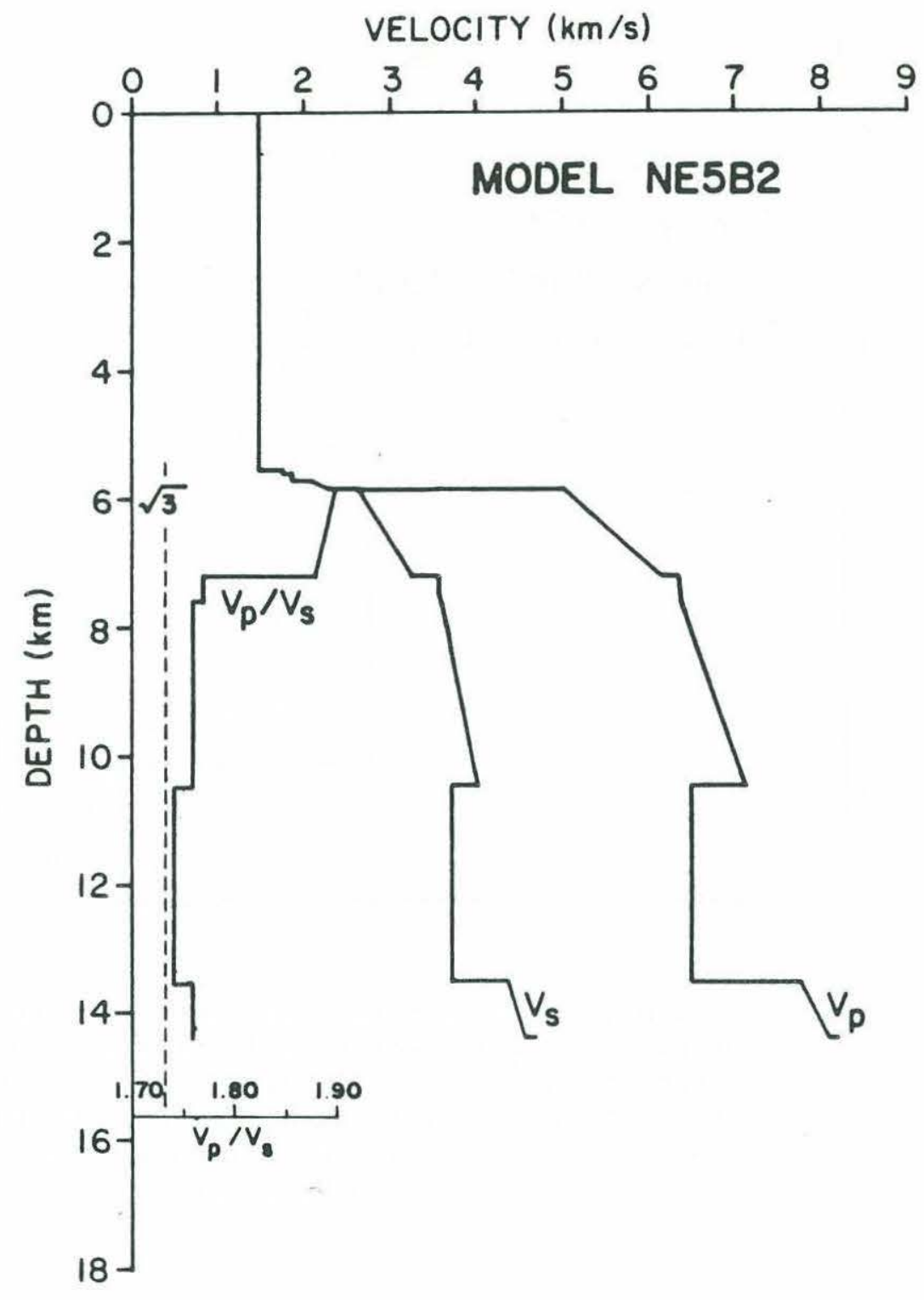

Figure 5. Compressional and shear velocity profiles and computed Poisson's ratio from analysis of ESP 5 collected on the NAT. Data from Mithal (1986). 
Figure 6. Trackline chart showing 1ocation of NAT and ESP 5

with respect to Sites $417 / 418$. Note also the location of the zero-offset fracture zone labeled "East". Chart from Mutter et al. (1985). Fracture zone locations from Schouten and K1itgord (1977).

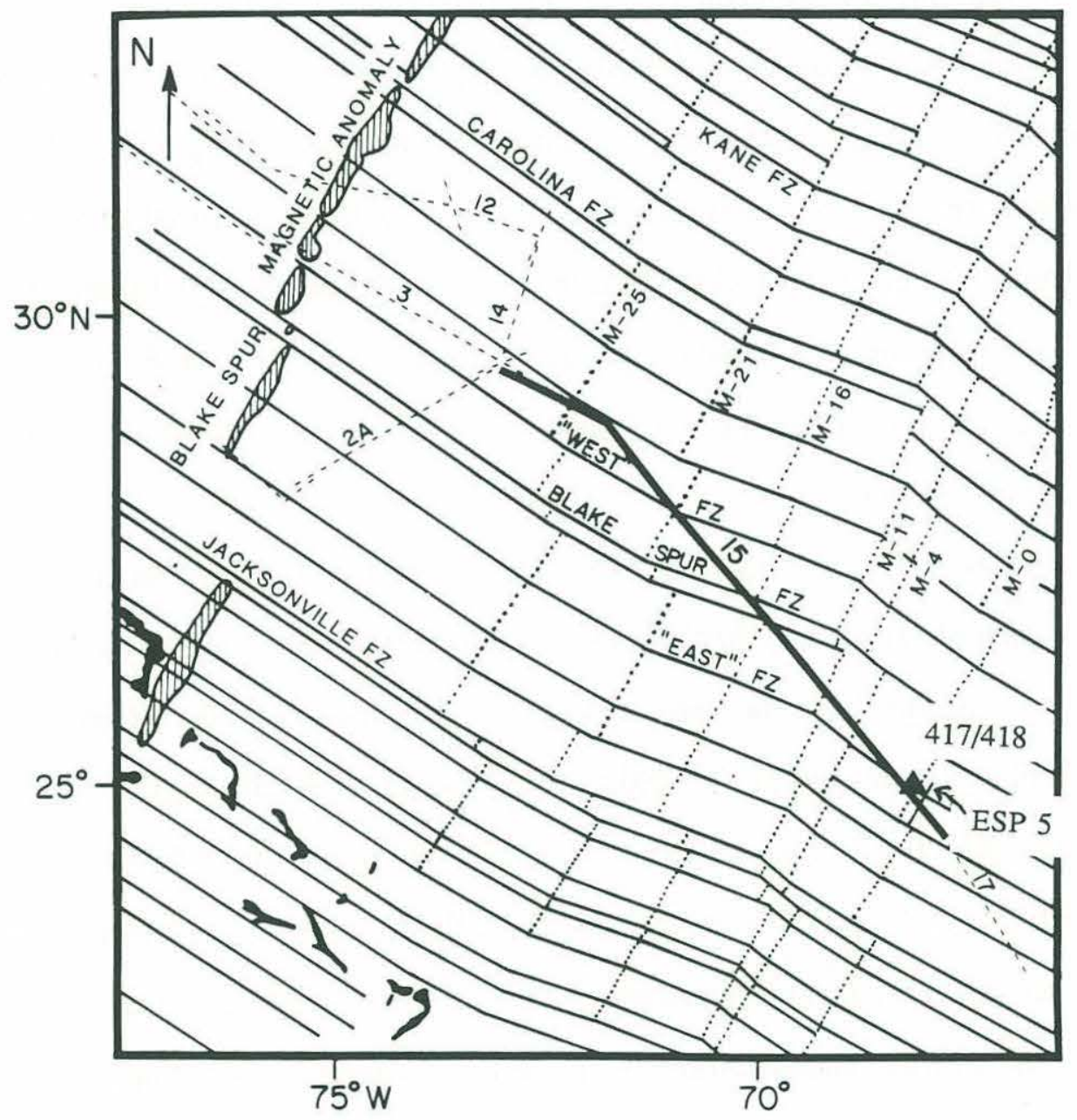


or whether the quality of refraction data elsewhere has simply been insufficient to resolve low-velocity zones within layer 3.

The nearest fracture zones, mapped on the basis of magnetic anomaly offsets, are located $37 \mathrm{~km}$ to the north-northeast of Site 418 and $60 \mathrm{~km}$ to the south-southwest (Figure 7; Hoskins and Groman, 1976; Rabinowitz et al., 1980). The length of crust between these two fracture zones is twice the length observed in regions of Mesozoic crust mapped with closely spaced aeromagnetic lines (Schouten and Klitgord, 1982). The possibility arises that a zero-offset fracture zone with anomalous crustal structure (Schouten and White, 1980) exists 10-13 km south of Site 418. Schouten and Klitgord (1977) mapped such a feature and labeled it the "East" Fracture Zone (Figure 6). Based on limited depth-to-basement data, Senske and Stephen (1988) proposed a fracture zone lying 12.5 km north-northeast of Site 418.

Basement occurs at $\sim 5800 \mathrm{~m}$ depth with variations up to $\pm 300 \mathrm{~m}$ in troughs and ridges (Figure 8; Senske and Stephen, 1988). Larger basement features tend to be aligned parallel or perpendicular to the trend of magnetic anomalies, $\mathrm{N} 25^{\circ} \mathrm{E}$. Basement maps are not available for larger geographic scales. It is clear from the reflection profiles in Rabinowitz et al. (1980) that relief exceeds $\pm 500 \mathrm{~m}$ within $50 \mathrm{~km}$ of Site 418 .

Both sites 417 and 418 are located on the flanks of modest basement highs (Figure 8). The difference in depth to basement of $146 \mathrm{~m}$ between Holes 417A and 417D located $\sim 450 \mathrm{~m}$ apart (Table 1) demonstrates the presence of steep basement slopes. This high spatial frequency relief cannot be resolved by available seismic reflection data and, thus, is not apparent in Figure 8.

The P-wave velocity profile at $418 \mathrm{~A}$ does not differ significantly at the $95 \%$ confidence level from that at 417D located $\sim 7.5 \mathrm{~km}$ away (Swift and Stephen, in press; see section below on borehole seismic experiments). Seismic velocities do vary laterally at shorter length scales. A travel time anomaly indicates that seismic velocity in the upper 0.5 


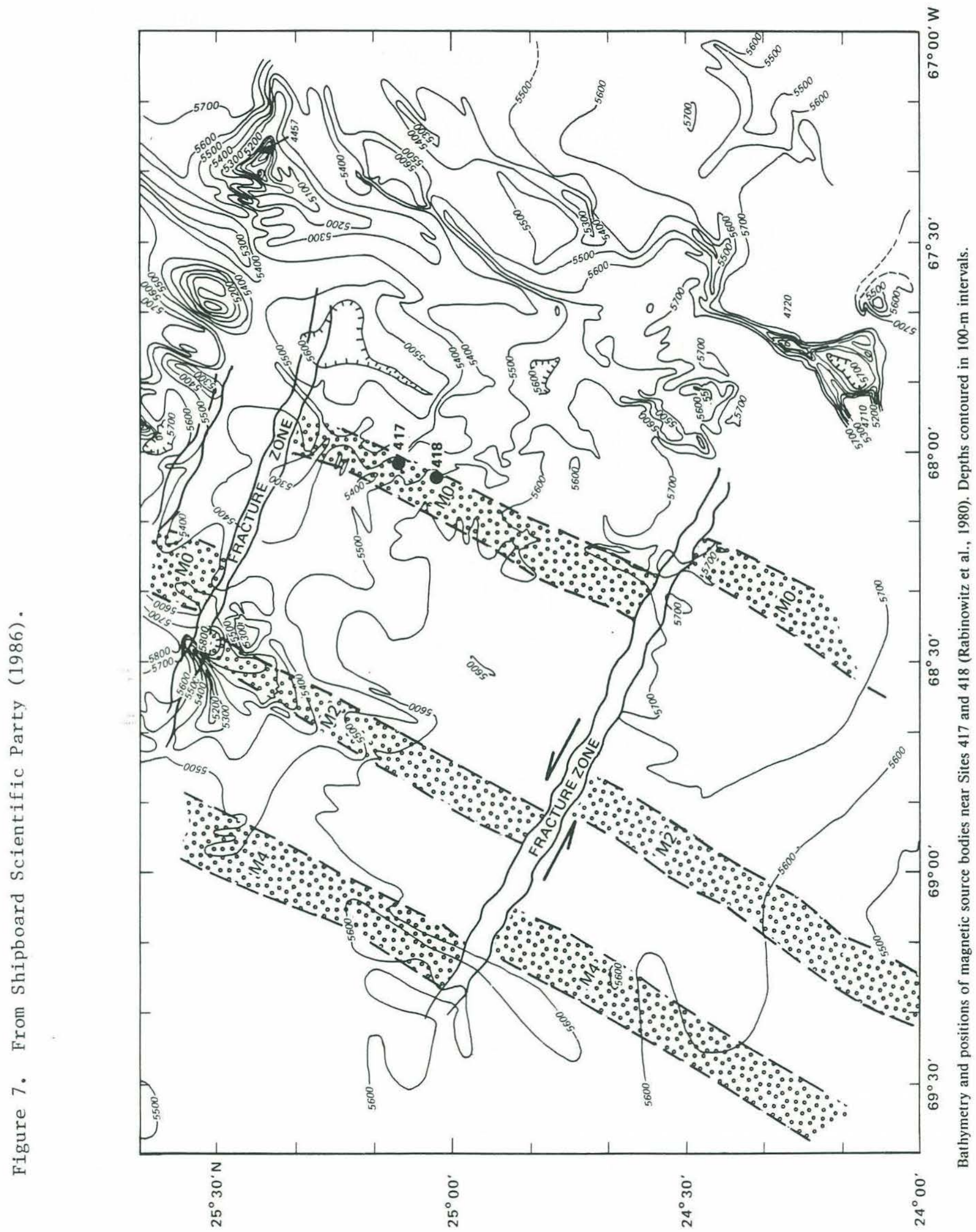


Figure 8. Depth to basement (meters) from Senske and Stephen (1988). $68^{\circ} 00^{\prime} \mathrm{W}$

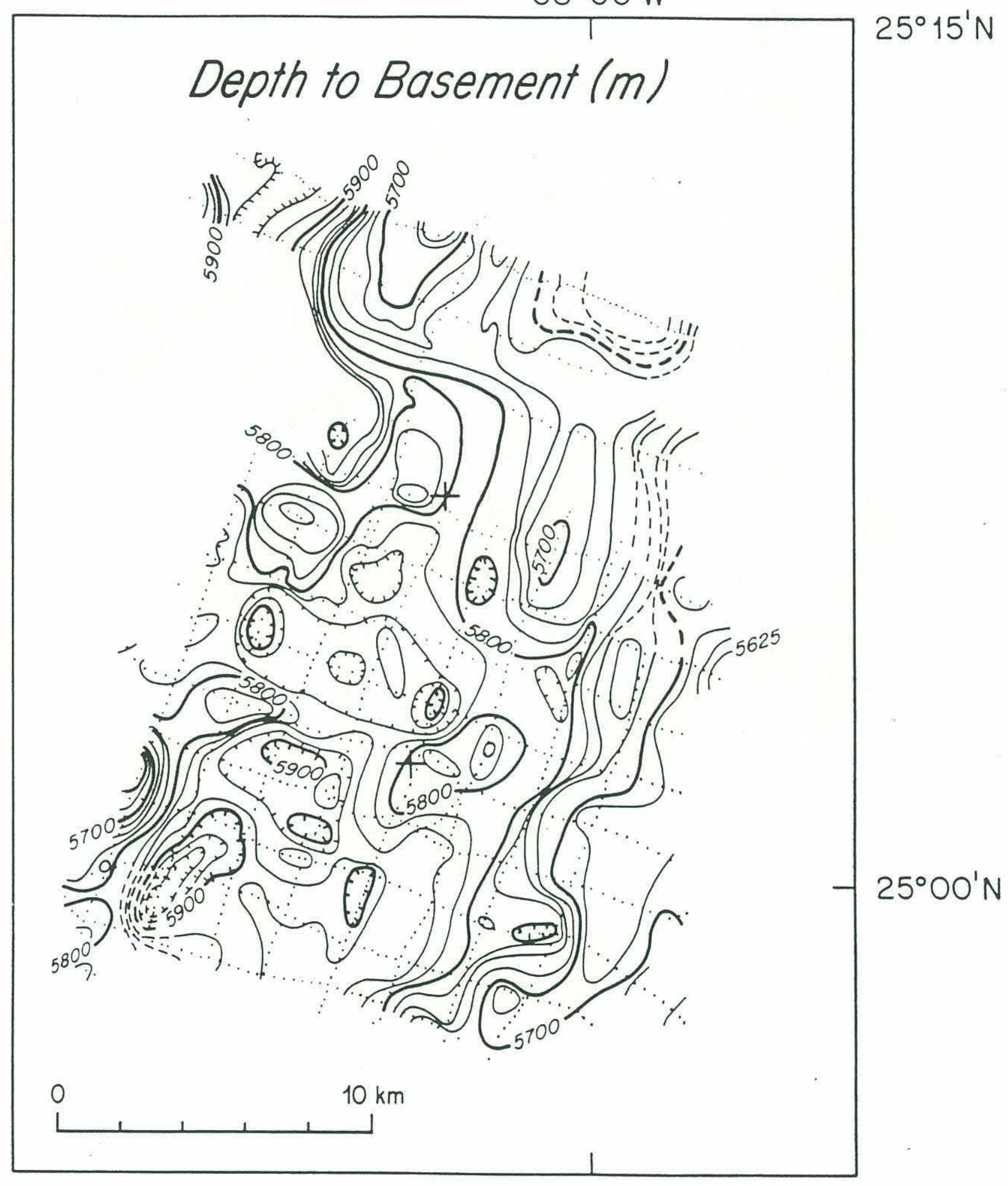


$\mathrm{km}$ of basement increases laterally northward out to $5 \mathrm{~km}$ shooting range. We discuss these results in greater detail in the section on borehole seismometer studies.

Sedimentary Development

Sediment thickness near the drill sites averages $\sim 300 \mathrm{~m}$ but ranges from less than $100 \mathrm{~m}$ on basement ridges to $\sim 500 \mathrm{~m}$ in basement lows (Figure 9; Senske and Stephen 1988). Sediment lithologies recovered at the four holes drilled to basement (Figure 10) may be divided into four facies: (1) a basal carbonate-rich facies of early Aptian age; (2) a black shale facies of Aptian-Albian age; (3) clay facies which lasted from Late Cretaceous to present and was briefly interrupted in the middle Eocene by deposition of (4) siliceous rich clay. From just prior to the Aptian to late Aptian-Albian, when Sites 417 and 418 were still near the ridge crest, the carbonate compensation depth rose from below $5000 \mathrm{~m}$ to about $3000 \mathrm{~m}$ (Arthur and Dean, 1986). Only the clay and siliceous clay facies were recovered on the basement high drilled at 417A. Currents probably swept early pelagic carbonate sediments off basement highs into lows (Tucholke and Vogt, 1979). The basal sedimentary sections within basement lows (Figure 8 ) are likely to be predominantly carbonates.

\section{GEOPHYSICAL STUDIES}

\section{Magnetics}

Hoskins and Groman (1976) collected the only systematically surveyed magnetic data in the area of Sites 417/418. Rabinowitz et al. (1980) supplemented these lines with magnetic data collected on publically available transits of the region and published the magnetic source block interpretation in Figure 7. On larger scales, the most recent published compilations of marine magnetic anomalies are those in Schouten and Klitgord (1977) and Klitgord and Schouten (1986). 
Figure 9. Total sediment thickness chart from Senske and Stephen (1988).

\section{Total Sediment Thickness}

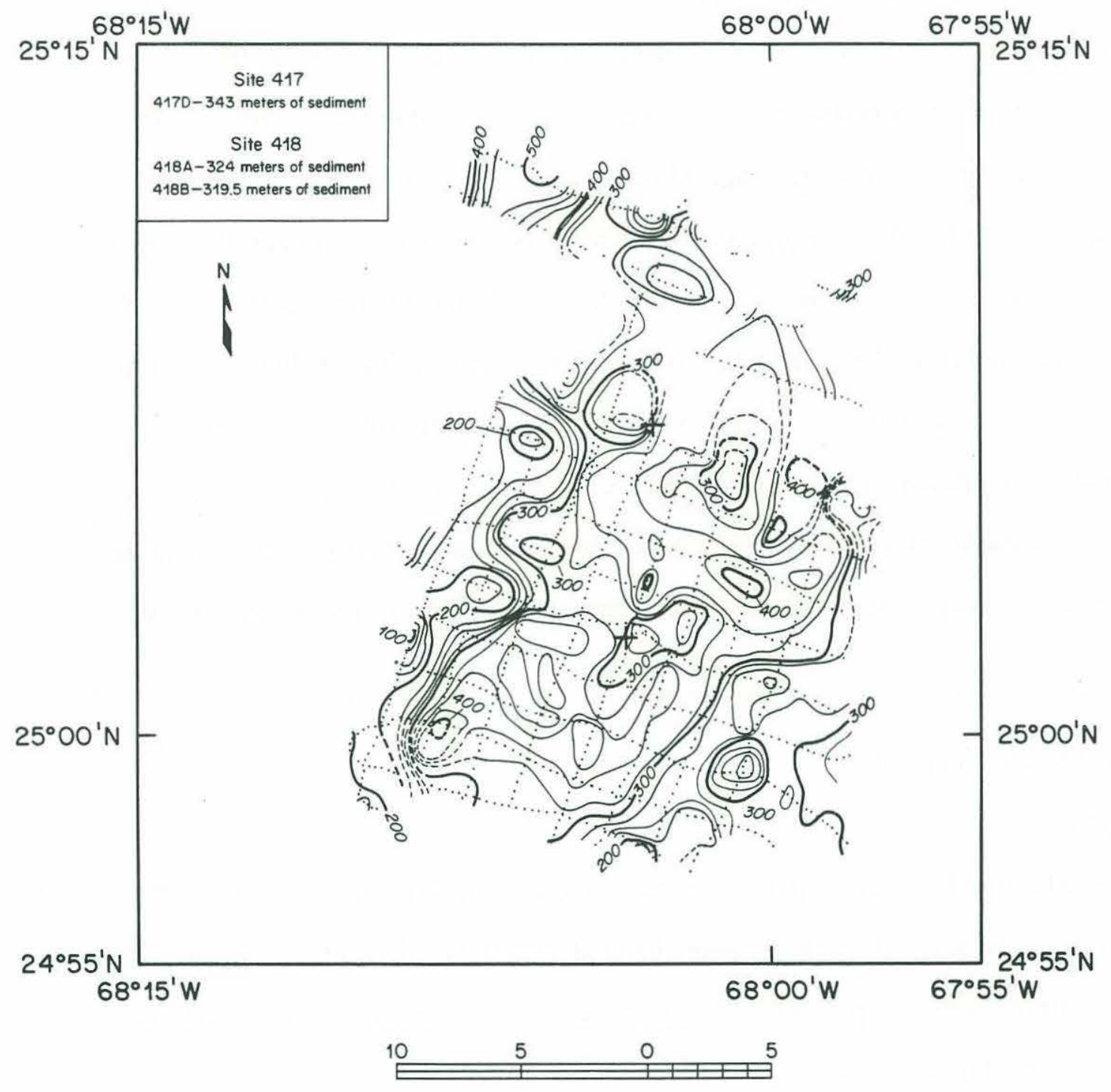

$1: 136,300$

Contours in Meters

Contour Interval $=25$ meters

Sediment Velocity $=1600 \mathrm{~m} / \mathrm{s}$ 
Figure 10. Sediment lithology sections at holes which penetrated to basement during DSDP Legs 51,52 , and 53 .

Compiled from Donnelly et al. (1980).

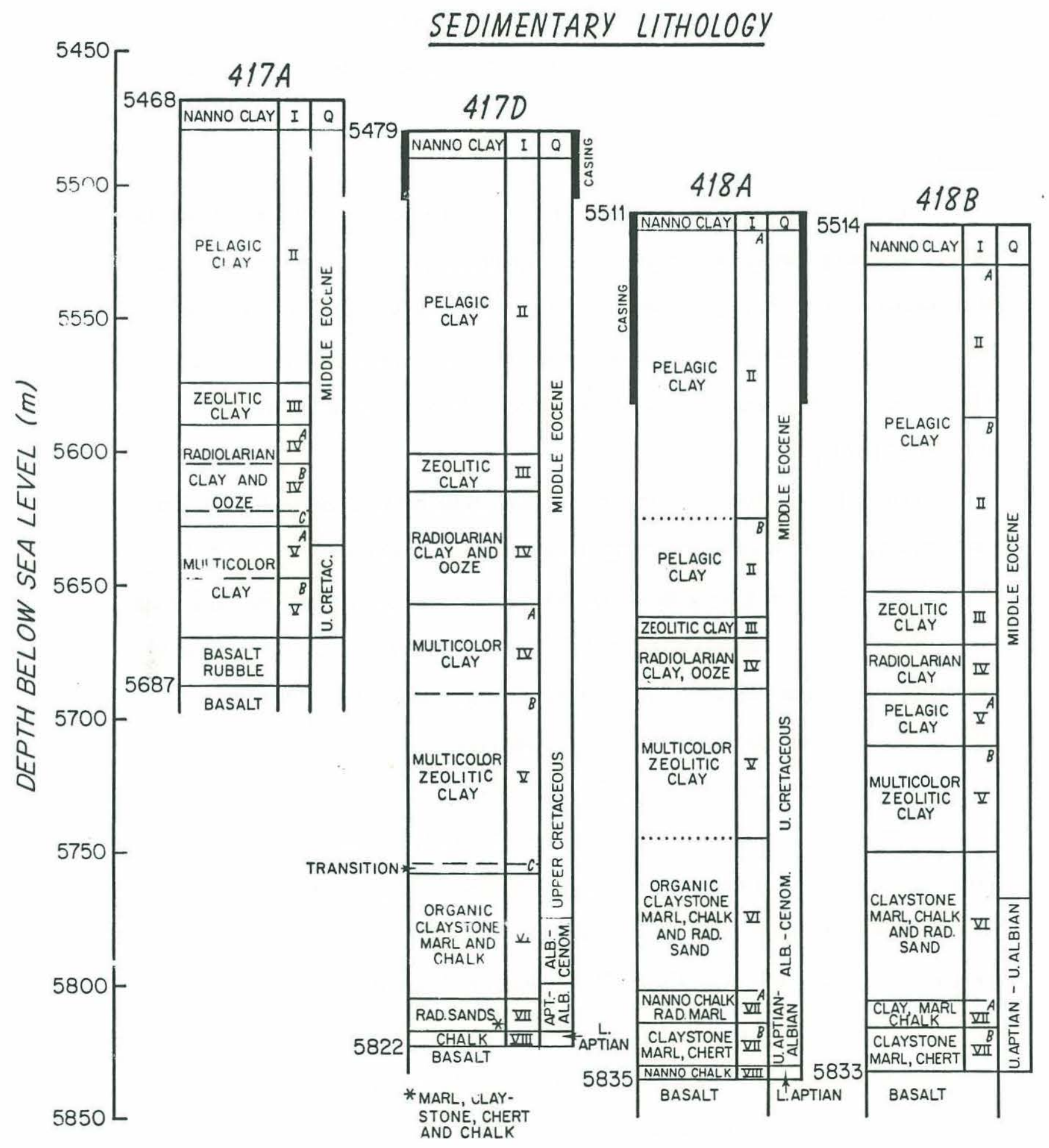




\section{Gravity}

No gravity data were collected during detailed surveys of Sites 417/418. Basinwide compilations of gravity data indicate that the free-air gravity anomaly at Sites 417 and 418 is -20 to -30 mgals and has no steep gradients (Bowin et al., 1982; Rabinowitz and Jung, 1986).

Heat Flow

In 1978, Galson and Von Herzen (1981) made a detailed heat flow survey of Sites 417 and 418 using a multi-penetration "pogo" technique. The mean and standard deviation of all values are $1.13 \mathrm{HFU}\left(\mu \mathrm{cal} / \mathrm{cm}^{2} \mathrm{~s}\right)\left(47.3 \mathrm{~m} \mathrm{~W} / \mathrm{m}^{2}\right)$ and $0.05 \mathrm{HFU}\left(2.1 \mathrm{~m} \mathrm{~W} / \mathrm{m}^{2}\right)$, respectively. Using heat flow modeling, Galson and Von Herzen (1981) show that refractive effects of basement topography can account for some of the variability. Reflection Seismics

Table 2 lists the National Geophysical Data Center (NGDC) accounting of ships which collected vertical incidence seismic reflection data within the area $24^{\circ}-26^{\circ} \mathrm{N}, 67^{\circ}$ $69^{\circ} \mathrm{W}$. Rabinowitz et al. (1980) show most profiles collected prior to and during drilling. In 1981, a two-ship common depth profile was shot over Sites 417/418 as part of the North Atlantic Transect (NAT) (NAT Study Group, 1985; Mutter et al. 1985). Figure 6 shows the profile location. Figure 11 from Mutter et al. (1985) reproduces the portion of the processed profile nearest Sites 417/418.

During ODP Leg 102 operations at Hole 418A, the R/V FRED MOORE collected profiles with both five-channel and one-channel streamers in a grid with $2 \mathrm{~km}$ line spacing. The FRED MOORE used an $80 \mathrm{in}^{3}$ water gun as a source. The ship tracklines and profiles are presented in Auroux and Stephen (1986). Senske and Stephen (1988) correlated the profiles to borehole stratigraphy (Figure 12) and mapped depth to seafloor (Figure 3), prominent reflectors (Figure 13), and top of basement (Figure 8).

Vertical-incidence profiles using a near-bottom, towed receiver were collected close to the drillsites on two occasions. In 1977, Bryan (1980) showed the feasibility of the 
$\circlearrowright_{Z}^{\bigcup} x \times x \times \quad x \times x \times x \times x \times x \times x \times x \times x \times x \times x \times \quad x \times x \times x \times \quad x$

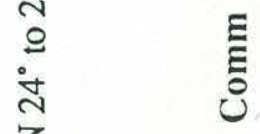

வ்

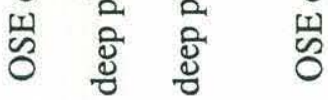

(1)

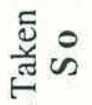

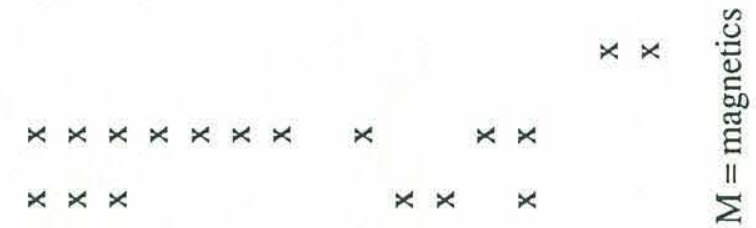

T)

元

芩

芯 $\Sigma \times x \times x \times x \times$

స్ऽ $\times \times$

¿ी

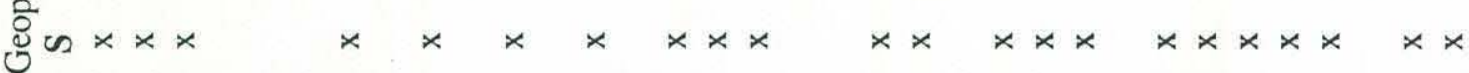

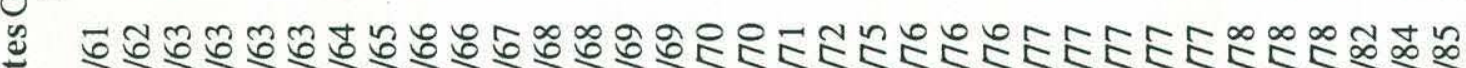

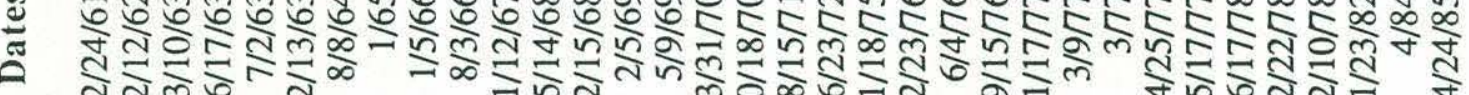

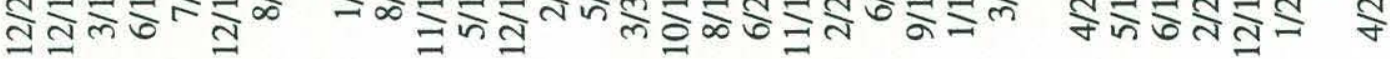

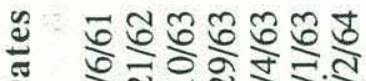

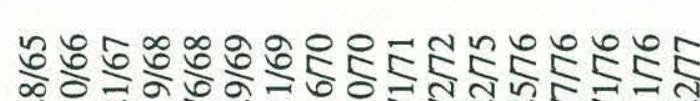

₹К

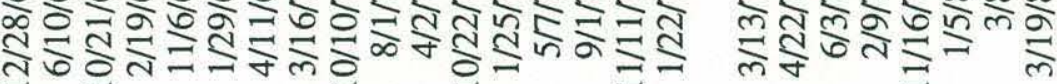

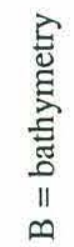

$N$

幽

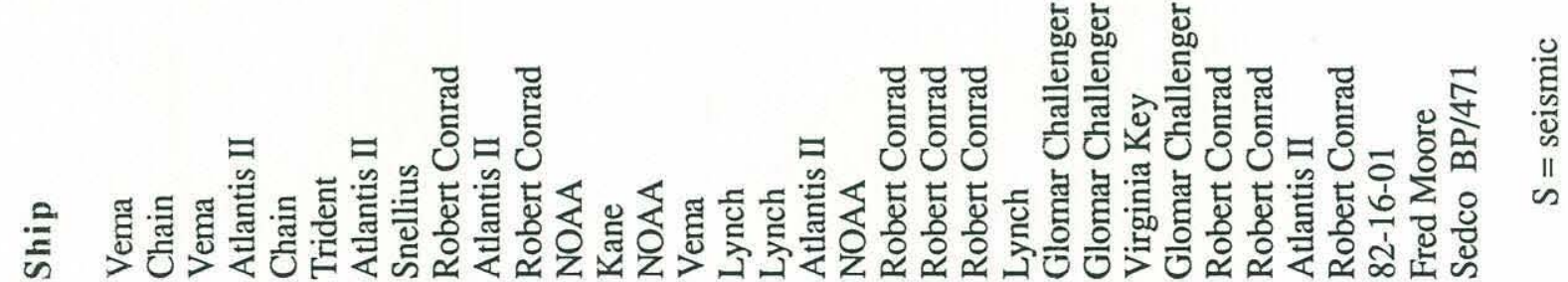



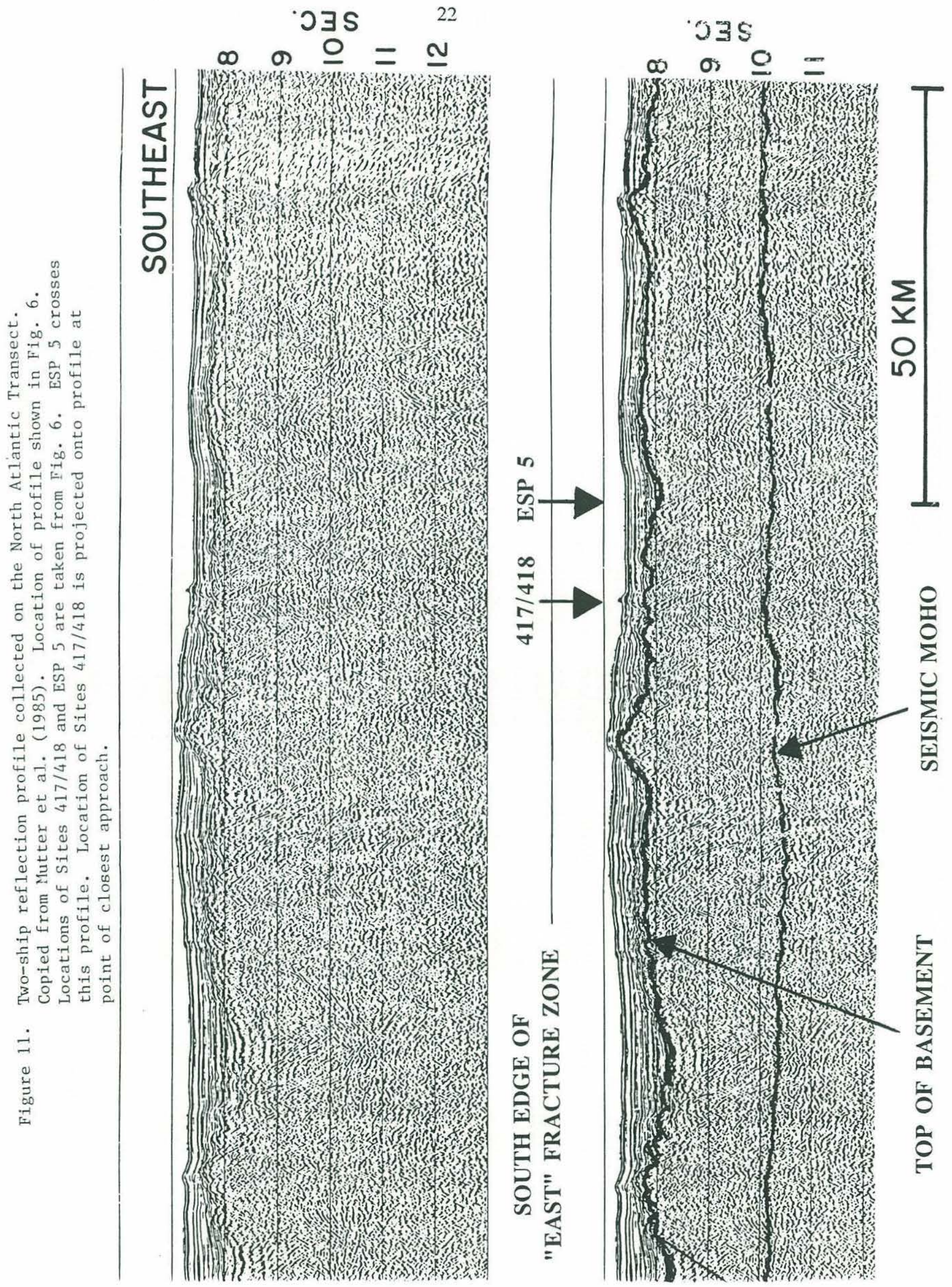
Figure 12. Correlation between reflectors and lithology at Holes 417D and 418A. From Senske and Stephen (1988).

\section{SITE 417D-LINE M}

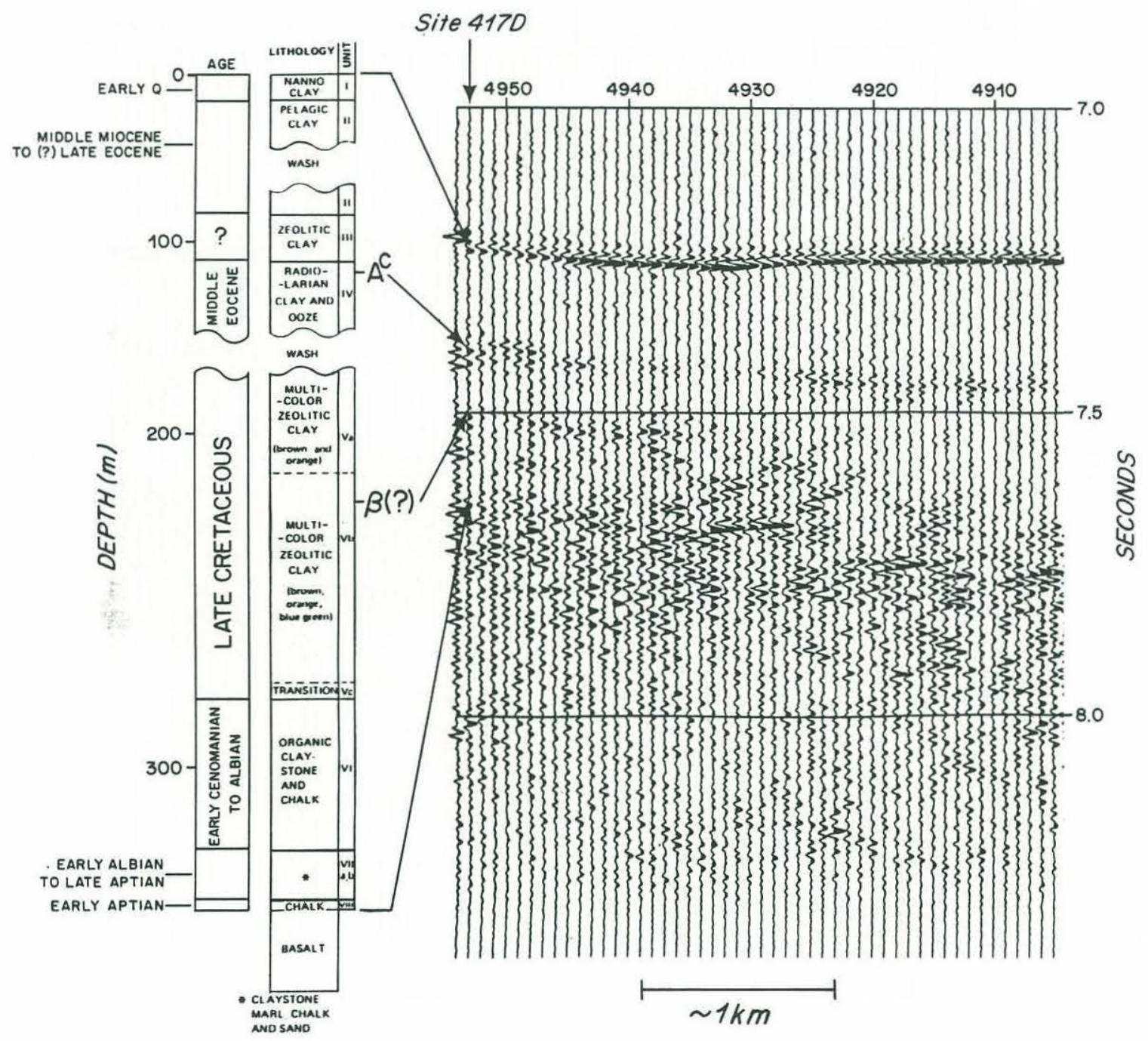


Figure 12 continued.

SITE 418B - LINE N

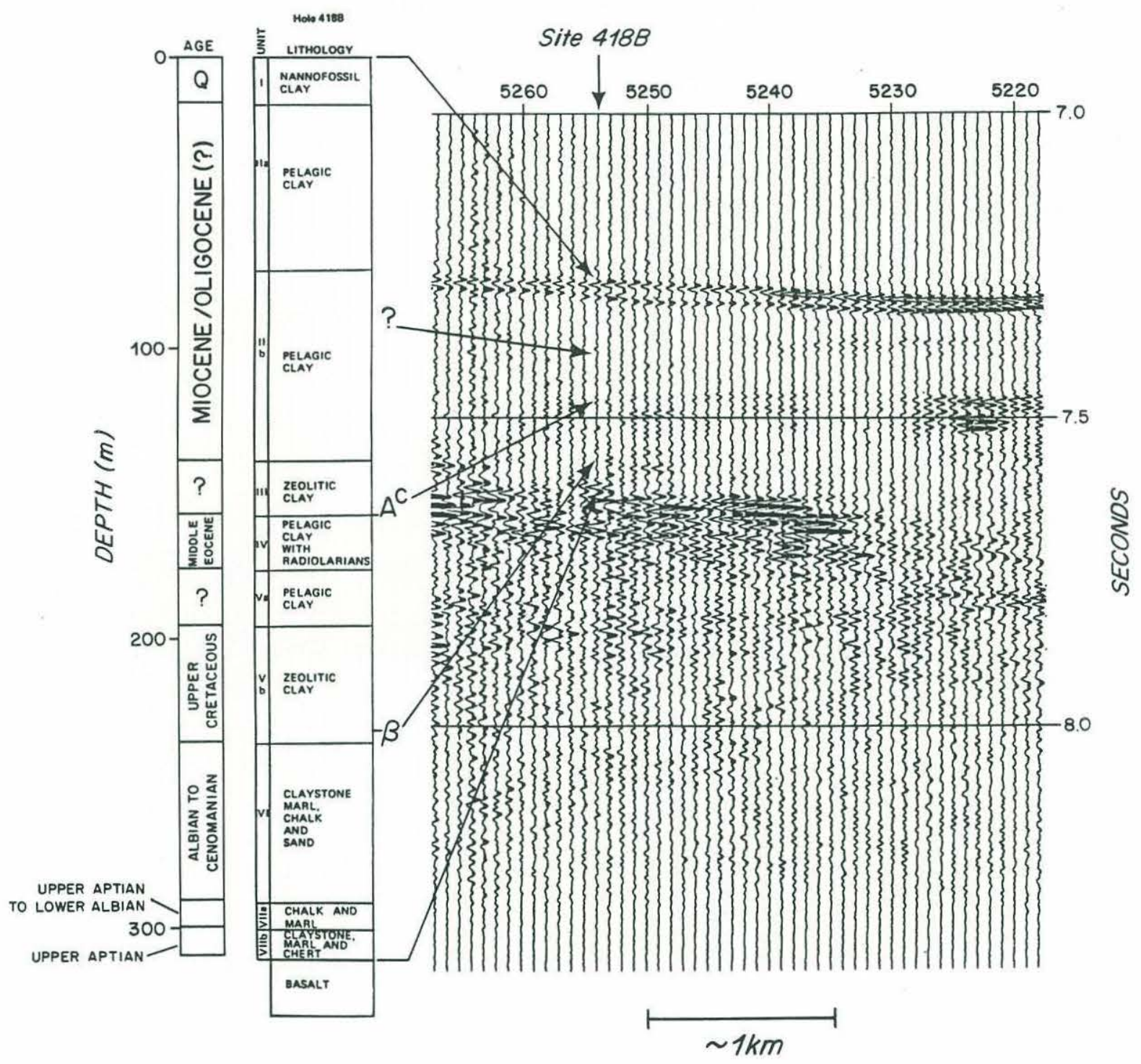


Figure 12 continued.

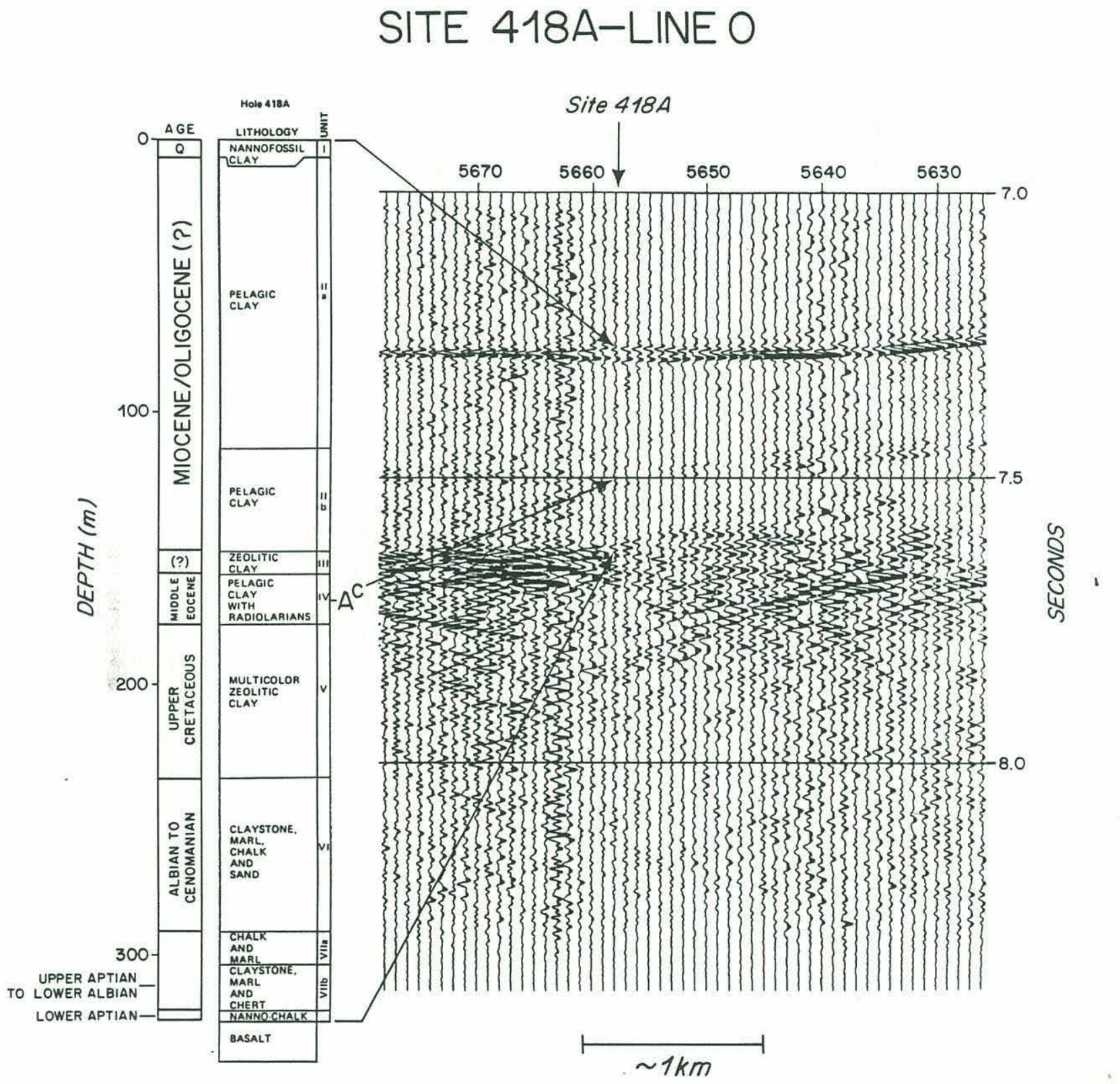


Figure 13a. Depth to Miocene/Oligocene reflector. From Senske and Stephen (1988)

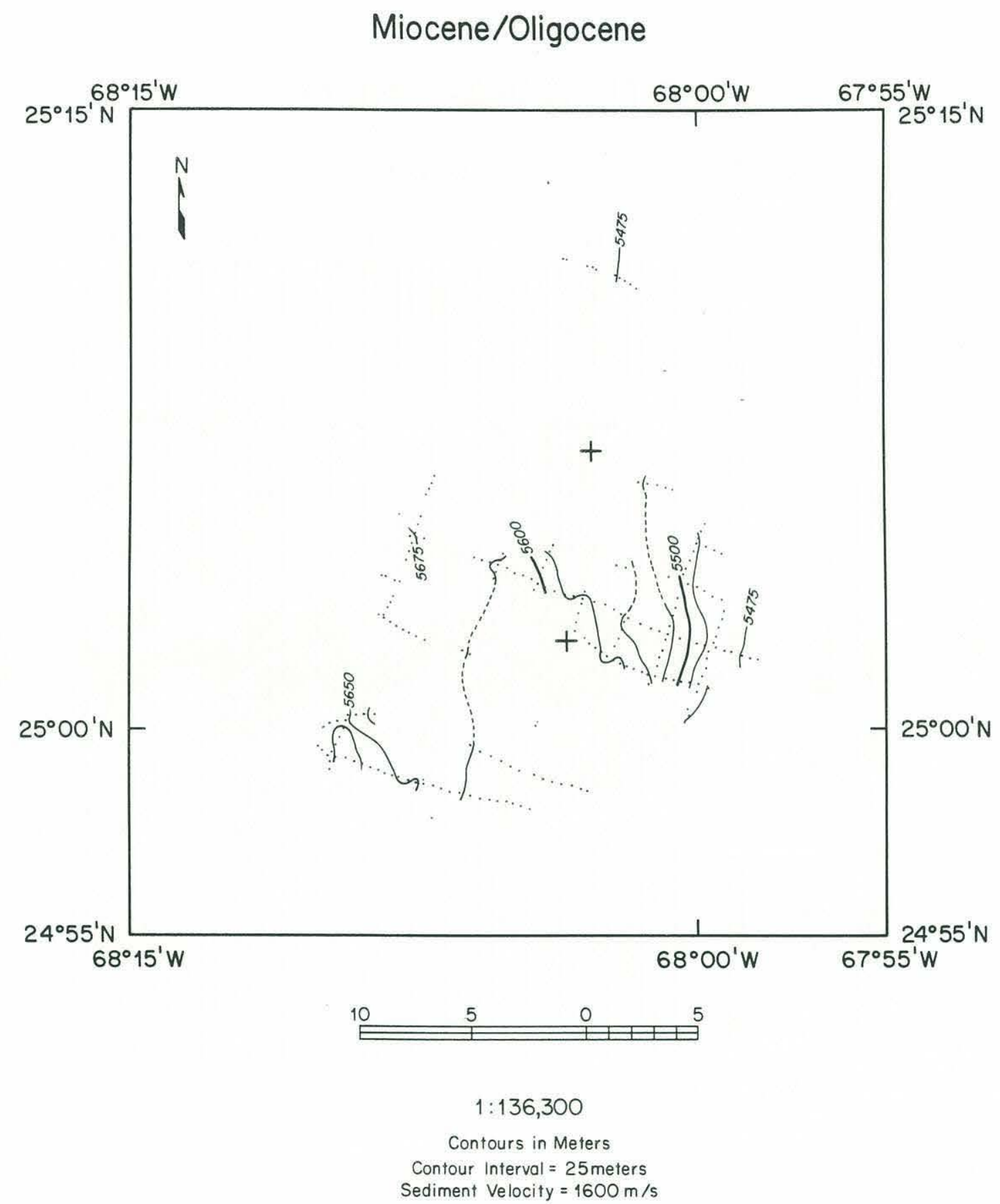


Figure 13b. Depth to Middle Eocene. From Senske and Stephen (1988).

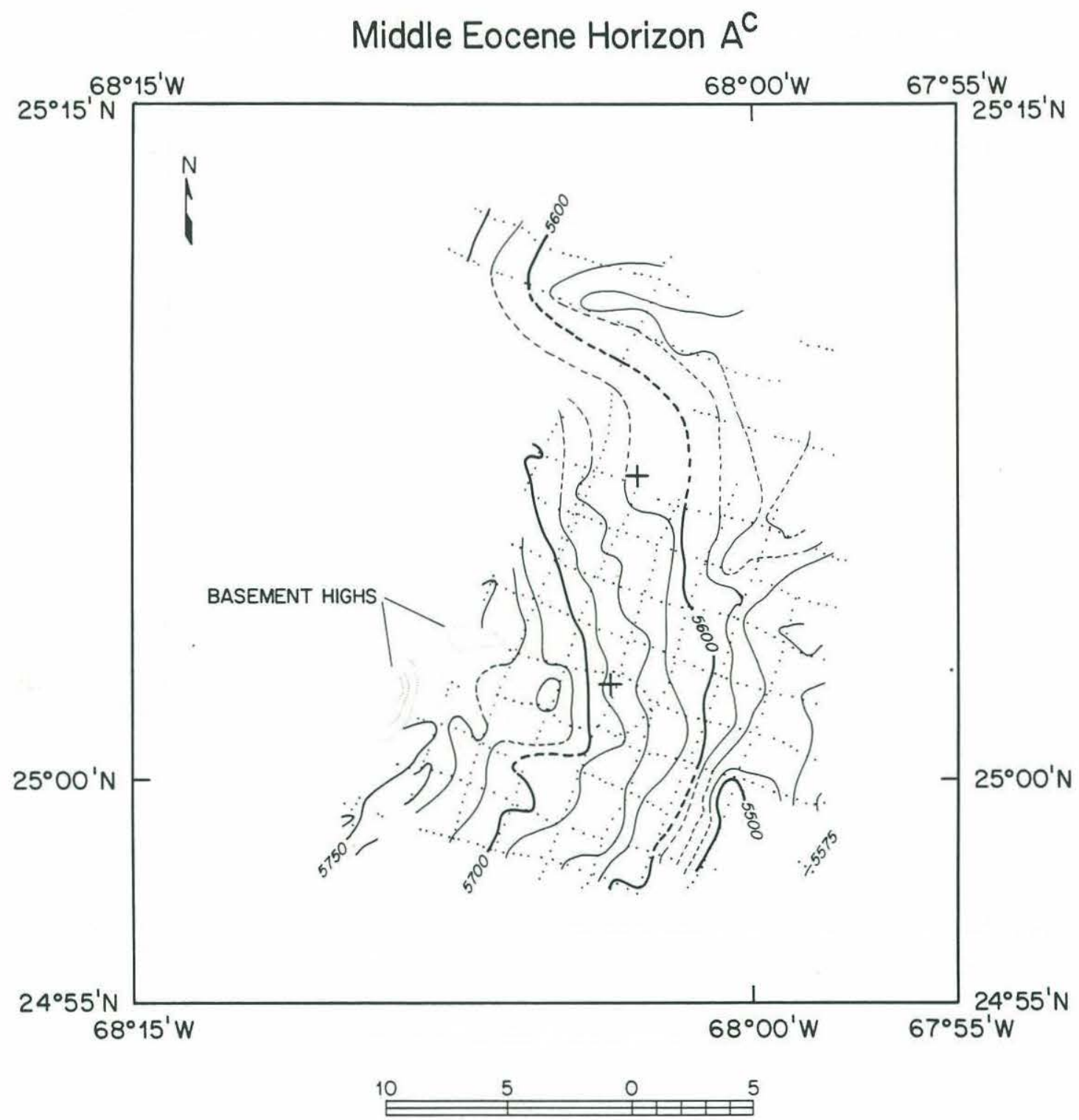

$1: 136,300$

Contours in Meters

Contour Interval $=25$ meters

Sediment Velocity $=1600 \mathrm{~m} / \mathrm{s}$ 
Figure 13c. Depth to Albian/Cenomanian reflector. From Senske and Stephen (1988)

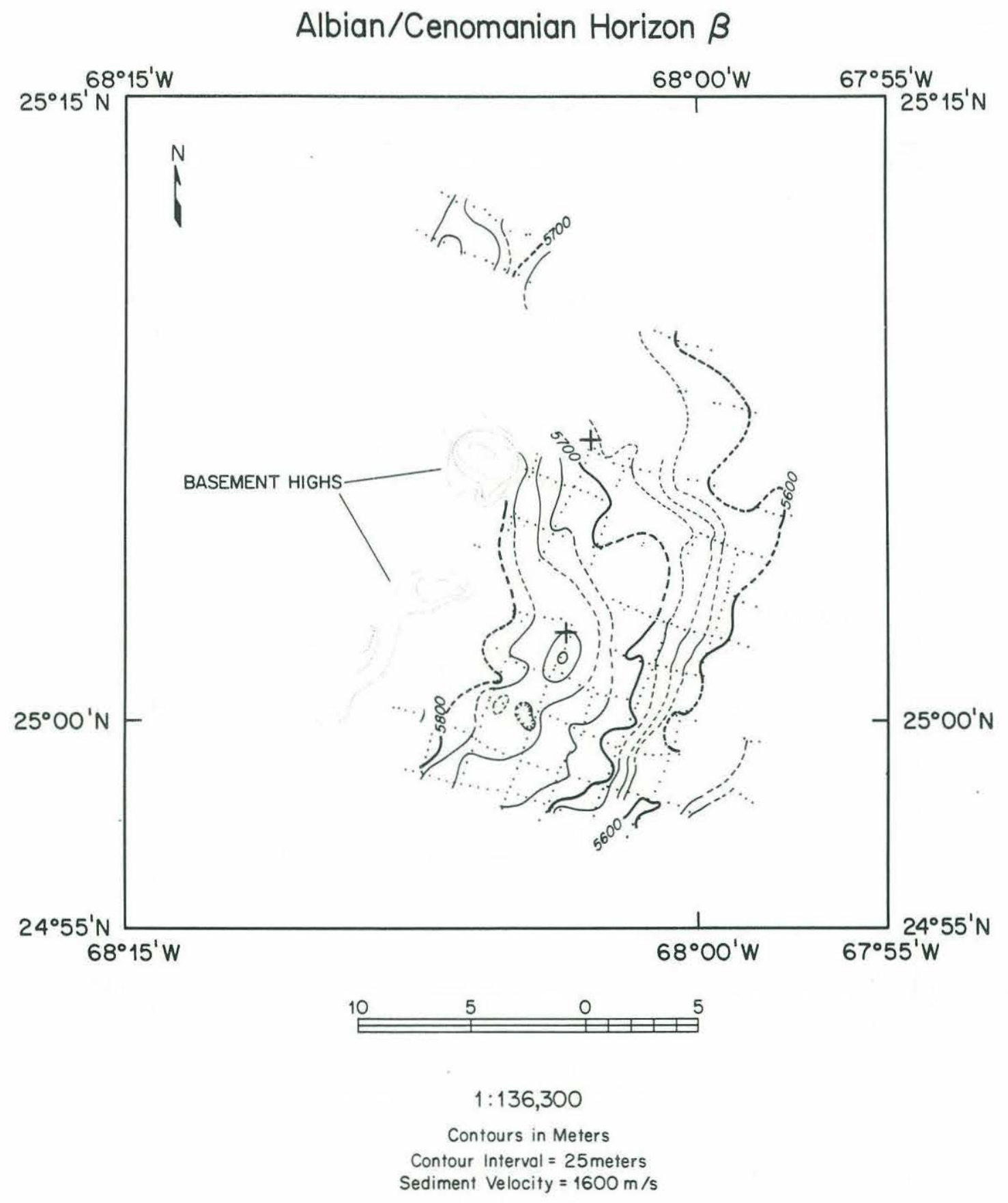


method by collecting a $4.5 \mathrm{~km}$ analog profile located about $3 \mathrm{~km}$ west of Site 417 . In 1978, Purdy et al. (1980) collected several profiles in the region, but only a $7.5 \mathrm{~km}$ long east-west profile across Site 417 was of sufficient quality to publish.

Three groups have published correlations between seismic stratigraphy and borehole sedimentary section. Donnelly et al. (1980) presented correlations as part of their site descriptions. Senske and Stephen (1988) correlated stratigraphy at Hole 418A to single-channel digital profiles (Figure 12). Carlson et al. (1988b) used the gamma ray log collected on ODP Leg 102 to make detailed correlations between Hole 418A stratigraphy and an analog profile. The seismic stratigraphy of the region has been discussed from a basin-wide perspective by Tucholke (1979), Tucholke and Mountain (1979), and Mountain et al. (1985).

\section{$\underline{\text { Refraction seismics }}$}

Refraction data have been collected at Sites 417/418 using sonobuoy receivers, borehole seismometers, and expanding-spread two-ship geometry. Sonobuoy refraction solutions from Lamont-Doherty Geological Observatory are cited by Donnelly et al. (1980; Part 1, p. 28), but the solutions have not been published. A sonobuoy was deployed from the SEDCO/BP 471 during ODP Leg 102 shooting, but the buoy drifted too fast to yield reliable velocity estimates.

Borehole seismic experiments were run on DSDP Leg 52 in Hole 417D (Stephen et al. 1980a,b) and on ODP Leg 102 in Hole 418 A (Swift et al., 1988; Swift and Stephen, in press). These results are discussed later in the section on borehole seismic experiments.

During the NAT, ESP 5 was shot on magnetic anomaly M0 near DSDP Sites 417/418 (Figure 6, NAT Study Group, 1985; Mithal, 1986). The velocity solution (Figure 5; Table 3) shows a crustal thickness similar to that between fracture zones. At the base of the crust, Mithal found an unusual, well-determined low-velocity zone. This layer has a uniform velocity of $6.5 \mathrm{~km} / \mathrm{s}$ and a thickness of $2.9 \mathrm{~km}$. This layer is capped by velocity of $7.1 \mathrm{~km} / \mathrm{s}$ and is underlain by the Moho velocity gradient to upper mantle velocities. 
Table 3. $P$ and $S$ velocities determined for NAT ESP 5 by Mithal (1986)

MODEL NE5B2

\begin{tabular}{lllllll} 
LAYER & \multicolumn{1}{l}{$\begin{array}{l}\text { DS } \\
(\mathrm{KM})\end{array}$} & $\begin{array}{l}\text { VPM } \\
(\mathrm{KM})\end{array}$ & $\begin{array}{l}\text { VPTOP } \\
(\mathrm{KM} / \mathrm{S})\end{array}$ & $\begin{array}{l}\text { VPBOT } \\
(\mathrm{KM} / \mathrm{S})\end{array}$ & $\begin{array}{c}\text { VSTOP } \\
(\mathrm{KM} / \mathrm{S})\end{array}$ & $\begin{array}{c}\text { VSBOT } \\
(\mathrm{KM} / \mathrm{S})\end{array}$ \\
\hline 1 & & & & & & \\
2 & 5.587 & 5.587 & 1.510 & 1.510 & & \\
3 & .068 & 5.655 & 1.800 & 1.800 & & \\
4 & .090 & 5.745 & 1.900 & 1.900 & & \\
5 & .132 & 5.877 & 2.100 & 2.300 & & \\
6 & 1.346 & 7.223 & 5.050 & 6.160 & 2.661 & 3.282 \\
7 & .415 & 7.638 & 6.360 & 6.400 & 3.590 & 3.613 \\
8 & 2.868 & 10.506 & 6.400 & 7.140 & 3.637 & 4.050 \\
9 & 3.055 & 13.561 & 6.500 & 6.500 & 3.742 & 3.742 \\
10 & .889 & 14.450 & 7.770 & 8.100 & 4.421 & 4.605
\end{tabular}




\section{BOREHOLE SEDIMENT STUDIES}

\section{Lithostratigraphy}

Detailed descriptions of sediment lithology and shipboard chemical analyses are published in the DSDP site reports (Donnelly et al., 1980, Part 1). Sediment recovery was generally poor (33-58\%, Table 1 ). Figure 10 shows sediment sections in the four holes drilled to basement. Tables 4 and 5 summarize the lithologic units assigned by shipboard scientists.

\section{Mineralogy and Chemistry}

Sediments at the two sites are 65-90\% clay minerals except in the Aptian chert and carbonate interbeds overlying basement (Mann and Muller, 1980; Rusinov and Kelts, 1980). The balance is $5-15 \%$ quartz with trace amounts of feldspar, pyroxene, and authigenic minerals. Smectite is the most common clay mineral, with illite being more common at the top and bottom of the sections. Chemical analyses of sediments reveal a late Cenozoic rhyolitic ash bed at $\sim 40 \mathrm{~m}$ depth in Hole $417 \mathrm{~A}$, similar in composition to Eocene age ash beds in Holes 417D and 418A (Donnelly, 1980). The basal sediments are enriched in iron, magnesium, and potassium. Organic matter in the Early Cretaceous black clays and claystones has both a marine and continental origin (Deroo et al., 1980). Organic carbon contents of these basal sediments range from 1-10\%. Borella and Adelsek (1980) suggest that manganese-enriched rhodochrosite minerals and $\mathrm{Mn}$-oxide grains formed in situ from mobile Mn. Gieskes and Reese (1980) attribute differences between Sites 417 and 418 in the vertical gradient of calcium in interstitial water to diffusion from basement and to differences in basement porosity related to different basalt type.

\section{Micropaleontology}

Donnelly et al. (1980) report the results of shipboard micropaleontology studies. At both sites, foraminifera are common in the uppermost sediment core and lowermost carbonate-rich beds overlying basement but are absent in most of the remaining section (Miles and Orr, 1980). Radiolarians and other siliceous microfossils are common, 
Table 4. From Donnelly et al. (1980)

Sedimentary Lithologic Units From Site 417

\begin{tabular}{|c|c|c|c|c|c|c|c|c|}
\hline \multirow[b]{2}{*}{ Unit } & \multirow[b]{2}{*}{ Lithology/Comments } & \multirow{2}{*}{$\begin{array}{l}\text { Chronostratigraphic } \\
\text { Unit }\end{array}$} & \multicolumn{3}{|c|}{ Holes 417 and $417 \mathrm{~A}$} & \multicolumn{3}{|c|}{ Holes $417 \mathrm{~B}$ and +171 ) } \\
\hline & & & Depth $(m)$ & Thickness (m) & Core/Section/Interval & Depth $(\mathrm{m})$ & Thickness (m) & Core/Section/Interval \\
\hline 1 & $\begin{array}{l}\text { Brown pelagic clay with } \\
\text { Nannofossil ooze horizons }\end{array}$ & Eurly Quaternary & $0-8.5$ & 8.5 & $417-1.417 \mathrm{~A}-1.417 \mathrm{~B}-1$ & 0.9 .5 & 9.5 & $417 \mathrm{~B}-1.417 \mathrm{D}-1$ \\
\hline II & $\begin{array}{l}\text { Yellow brown to pale brown } \\
\text { pelagic clay. Includes some } \\
\text { biue ash }\end{array}$ & $\begin{array}{l}\text { Middle Miocene to } \\
\text { (?) late Eocene }\end{array}$ & $8.5 \cdot 105.7$ & 97.2 & $\begin{array}{l}417 \mathrm{~A}-2 \text { to } 417 \mathrm{~A}-12-2 \\
70 \mathrm{~cm}\end{array}$ & - & - & (washed $7.5 \cdot 125 \mathrm{~m}$ ) \\
\hline III & Dark brown zeolitic clay & $?$ & $105.7 \cdot 122.5$ & 16.8 & $\begin{array}{l}417 \mathrm{~A}-12-2,70 \mathrm{~cm} \text { to } \\
417 \mathrm{~A}-13-3\end{array}$ & $\begin{array}{l}? 122.0- \\
136.0\end{array}$ & 14 & $417 D-3$ \\
\hline IV & $\begin{array}{l}\text { Dark brown radiolarian } \\
\text { ooze to clay } \\
\text { IVa Zeolitic } \\
\text { IVb Non-zeolitic } \\
\text { IVc Zeolitic }\end{array}$ & Middle Eocene & $\begin{array}{l}122.5-160.5 \\
122.5-136.5 \\
136.5-151.0 \\
151.0-160.5\end{array}$ & 38 & $\begin{array}{l}417 A-13-4 \text { to } 417 A-18-7 \\
417 A-13-4 \text { to } 417 A-15-3 \\
417 A-15-4 \text { to } 417 A-16 . C C \\
417 A-17\end{array}$ & $\begin{array}{l}? 136.0- \\
178.0\end{array}$ & 42 & $\begin{array}{l}417 \mathrm{D}-4 \text { (washed } 144.5 \\
\text { to } 192.0 \mathrm{~m} \text { ) }\end{array}$ \\
\hline V & $\begin{array}{l}\text { Multicolored zeolite clay } \\
\text { Va Pale and dark yellow- } \\
\text { brown, slightly zeolitic } \\
\text { Vb Yellow-browns and } \\
\text { pale green zeolite-rich } \\
\text { Vc Transition }\end{array}$ & Late Cretaceous & $\begin{array}{l}160.5-149.5 \\
160.5-179.5 \\
179.5-199.5^{a} \\
\text { Basalt Rubbleb }\end{array}$ & $\begin{array}{l}39 \\
19 \\
20\end{array}$ & $\begin{array}{l}417 \text { A-18-1 to } 417 \text { A-21. } \\
\text { CC } \\
417 \text { A-18-1 to } 417 \text { A-19, } \\
\text { CC } \\
417 \text { A-20-1 to } 417 \text { A-22-1, } \\
100 \mathrm{~cm}\end{array}$ & $\begin{array}{l}178.0- \\
279.5 \\
178.0 \\
212.0 \\
212-275.0 \\
275.0- \\
279.5\end{array}$ & $\begin{array}{l}101.5 \\
34 \\
63 \\
4.5\end{array}$ & $\begin{array}{l}417 \mathrm{D}-6-1 \text { to } 417 \mathrm{D}-15-2 . \\
60 \mathrm{~cm} \\
417 \mathrm{D}-6-1 \text { to } 417 \mathrm{D}-8, \mathrm{CC} \\
417 \mathrm{D}-8 . \mathrm{CC} \text { to } 417 \mathrm{D}- \\
14-4 \\
417 \mathrm{D}-14-5 \text { to } 417 \mathrm{D}-15-2 . \\
60 \mathrm{~cm}\end{array}$ \\
\hline VI & $\begin{array}{l}\text { Green to black organic } \\
\text { claystone marl and nanno- } \\
\text { fossil chalk including } \\
\text { radiolarian sands, pyrite, } \\
\text { chert, dolomite, and } \\
\text { phosphate }\end{array}$ & $\begin{array}{l}\text { Early Cenomanian } \\
\text { to Albian }\end{array}$ & & & & $\begin{array}{l}279.5- \\
325.8\end{array}$ & 46.3 & $\begin{array}{l}417 \mathrm{D}-15-2,60 \mathrm{~cm} \text { to } \\
417 \mathrm{D}-19 . \mathrm{CC}\end{array}$ \\
\hline VII & $\begin{array}{l}\text { Cyclic radiolarian sand to } \\
\text { marl to claystone } \\
\text { VIla Pale to dark brown } \\
\text { and pale green } \\
\text { VIlb Green and black with } \\
\text { nannofossil chalk and chert }\end{array}$ & $\begin{array}{l}\text { Early Albian to } \\
\text { late aptian }\end{array}$ & & & & $\begin{array}{l}325.0 \\
338.6\end{array}$ & $\begin{array}{r}13.6 \\
11.3 \\
2.3\end{array}$ & $\begin{array}{l}417 \mathrm{D}-20-1 \text { to } 417 \mathrm{D}-21-3 . \\
140 \mathrm{~cm} \\
417 \mathrm{D}-20-1 \text { to } 417 \mathrm{D}-21-2, \\
60 \mathrm{~cm} \\
417 \mathrm{D} \cdot 21-2.60 \mathrm{~cm} \text { to } \\
417 \mathrm{D}-21-3.140 \mathrm{~cm}\end{array}$ \\
\hline VIII & $\begin{array}{l}\text { Olive-gray, clayey nanno- } \\
\text { fossil chalk }\end{array}$ & Early Aptian & & & & $\begin{array}{l}338.6 \\
339.5 \mathrm{a} \\
\left(343^{\mathrm{b}}\right)\end{array}$ & 0.9 & $\begin{array}{l}417 \mathrm{D}-21-3,140 \mathrm{~cm} \text { to } \\
417 \mathrm{D}-21-4,60 \mathrm{~cm}\end{array}$ \\
\hline IX & $\begin{array}{l}\text { Glassy basalt with } \\
\text { interpillow limestone }\end{array}$ & & & & & $\begin{array}{l}\text { Below } \\
343^{c}\end{array}$ & & \\
\hline
\end{tabular}

a Basement according to position in core of the first basalt encountered.

Drilling in Hole 417A encountered altered pillow basalt basement. Driller's records indicate a basement contact at 208 meters sub-bottom. The top of basalt Cores $417 \mathrm{~A}-23$

and 24 contains, respectively, $40 \mathrm{~cm}$ and $20 \mathrm{~cm}$ of a drill breccia with basalt rubble, sand, and overlying clay.

Coring indicated basalt at 339.3 meters sub-bottom and driller's records at 343 meters. Checking with the logging tools, however, showed the sediment basalt interface located at 340 meters sub-bottom. 
Table 5. From Donnelly et al. (1980)

Sedimentary Lithologic Units - Site 418

\begin{tabular}{|c|c|c|c|c|c|c|c|c|}
\hline \multirow{2}{*}{$\begin{array}{l}\text { Unit/ } \\
\text { Sub- } \\
\text { Unit }\end{array}$} & \multirow[b]{2}{*}{ Lithology } & \multirow[b]{2}{*}{ Chronostra tigraphy } & \multicolumn{3}{|c|}{ Holes 418 and $418 \mathrm{~A}$} & \multicolumn{3}{|c|}{ Hole $418 \mathrm{~B}$} \\
\hline & & & $\begin{array}{l}\text { Depth } \\
\text { (m) }\end{array}$ & $\begin{array}{l}\text { Thickness } \\
\text { (m) }\end{array}$ & Core-Section, Interval & $\begin{array}{l}\text { Depth } \\
(\mathrm{m})\end{array}$ & $\begin{array}{l}\text { Thickness } \\
\text { (m) }\end{array}$ & Core-Section, Interval \\
\hline 1. & $\begin{array}{l}\text { Brown pelagic clay with } \\
\text { nannofossil horizons } \\
\text { (10YR 4/2) }\end{array}$ & Quaternary & $0.0-6.0^{\mathrm{a}}$ & 6.0 & $418-1$ & $0-16.3$ & $\sim 16.3$ & $\begin{array}{l}418 \mathrm{~B}-1 \\
418 \mathrm{~B}-2\end{array}$ \\
\hline 11 & $\begin{array}{l}\text { Pelagic clay } \\
\text { Yellow brown to paie } \\
\text { yellow gray, grayish } \\
\text { orange (10YR } 7 / 4) \text { to light } \\
\text { olive brown }(2.5 \text { Y } 5 / 4)\end{array}$ & $\begin{array}{l}\text { Miocene/Oligocene } \\
\text { (?) }\end{array}$ & $\begin{array}{l}111.0-151.2^{b} \\
\text { or } \\
6.0-151.2\end{array}$ & $\begin{array}{l}\quad 40.2(?) \\
\quad \text { or } \\
145.2 \text { to base } \\
\text { of Core } 1\end{array}$ & $418 \mathrm{~A}-1$ to $418 \mathrm{~A}-2$ & $16.3-139.1$ & 122.8 & $418 \mathrm{~B}-3-1$ to $418 \mathrm{~B}-15, \mathrm{CC}$ \\
\hline $\begin{array}{l}\mathrm{IIa} \\
\mathrm{IIb}\end{array}$ & $\begin{array}{l}\text { Yellow brown } \\
\text { Pale orange }\end{array}$ & & & & & $\begin{array}{l}16.3-73.3 \\
73.3-139.1\end{array}$ & $\begin{array}{l}57 \\
65.8\end{array}$ & $\begin{array}{l}418 \mathrm{~B}-3-1 \text { to } 418 \mathrm{~B}-8, \mathrm{CC} \\
418 \mathrm{~B}-9-1 \text { to } 418 \mathrm{~B}-15, \mathrm{CC}\end{array}$ \\
\hline III & $\begin{array}{l}\text { Dark gray brown pelagic clay } \\
\text { Some pale zeolitic interbeds }\end{array}$ & $?$ & $151.2-159.3$ & $\sim 8.1$ & $\begin{array}{l}418 A-5-2 \text { to } \\
418 A-6-1\end{array}$ & $139.1-158$ & 18.9 & $418 \mathrm{~B}-16-1$ to $418 \mathrm{~B}-17, \mathrm{CC}$ \\
\hline IV & $\begin{array}{l}\text { Dark gray brown to red brown } \\
\text { pelagic clay with radiolarians } \\
\left(2.4 Y^{4 / 2}\right)\end{array}$ & Middie Eocene & $159.3-177.5$ & $\sim 18.2$ & $\begin{array}{l}418 A-6-1 \text { to } \\
418 A-7, C C\end{array}$ & $158.0-177.2$ & 19.2 & $418 \mathrm{~B}-18-1$ to $418 \mathrm{~B}-19, \mathrm{CC}$ \\
\hline $\mathrm{Va}_{\mathrm{a}}$ & $\begin{array}{l}\text { Dark gray brown to red brown } \\
\text { pelagic clay }(5 \text { YR } 25 / 2)\end{array}$ & $?$ & $177.5-206 \mathrm{c}$ & -29.0 & $\begin{array}{l}418 \mathrm{~A}-7, \mathrm{CC} \text { to } \\
418 \mathrm{~A}-8, \mathrm{CC}\end{array}$ & $177.2-196.3$ & 19.1 & $\begin{array}{l}418 \mathrm{~B}-19, \mathrm{CC} \text { to } \\
418 \mathrm{~B}-21 . \mathrm{CC}\end{array}$ \\
\hline $\mathrm{Vb}$ & $\begin{array}{l}\text { Multicolored zeolite clay } \\
\text { Pale orange, brown to } \\
\text { pale green }\end{array}$ & Upper Cretacous & $-c$ & & & $196.3-236$ & 39.7 & $\begin{array}{l}418 \mathrm{~B}-22-1 \text { to } 418 \mathrm{~B}-26-1 \\
90 \mathrm{~cm}\end{array}$ \\
\hline vi & $\begin{array}{l}\text { Green, black, light to olive } \\
\text { gray, blue green claystones, } \\
\text { maris, nannofossil chalks and } \\
\text { radiolarian sands including } \\
\text { pyrite, chert and organics } \\
\text { (black-clay facies) }\end{array}$ & $\begin{array}{l}\text { Albian to } \\
\text { Cenomanian }\end{array}$ & $234.5-291.0^{d}$ & $\sim 56.4$ & $\begin{array}{l}418 A-9 \text { to } 418 A-11 \\
C C\end{array}$ & $236-291.6$ & 55.6 & $\begin{array}{l}418 \mathrm{~B}-26, \mathrm{CC} \text { to } \\
418 \mathrm{~B}-32-1,20 \mathrm{~cm}\end{array}$ \\
\hline VII & $\begin{array}{l}\text { Pale to dark red brown, pink } \\
\text { and pale green } \\
\text { Radiolarian claystones, clays, } \\
\text { marls and nannofossil chalks } \\
\text { and black to green clay } \\
\text { including chert }\end{array}$ & $\begin{array}{l}\text { Upper Aptian to } \\
\text { Albian }\end{array}$ & $291.5-324.0^{\mathrm{e}}$ & $\sim 32.5$ & $\begin{array}{l}418 A-12-1 \text { to } \\
418 A-15-1\end{array}$ & $291.6-319.5^{e}$ & 28.1 & $\begin{array}{l}418 \mathrm{~B}-32-1,30 \mathrm{~cm} \text { to } \\
418 \mathrm{~B}-34-1,60 \mathrm{~cm}\end{array}$ \\
\hline VIla & $\begin{array}{l}\text { Pale to dark red brown } \\
\text { nannofossil chalks to } \\
\text { radiolarian marls }\end{array}$ & $\begin{array}{l}\text { Upper Aptian to } \\
\text { lower Albian }\end{array}$ & $291.5-303.3$ & 11.8 & $\begin{array}{l}418 \mathrm{~A}-12-1 \text { to } \\
418 \mathrm{~A}-13-2,80 \mathrm{~cm}\end{array}$ & $291.6-301.6$ & 10 & $\begin{array}{l}418 \mathrm{~B}-32-1,30 \mathrm{~cm} \text { to } \\
418 \mathrm{~B}-33-1,60 \mathrm{~cm}\end{array}$ \\
\hline VIIb & $\begin{array}{l}\text { Black and green claystones, } \\
\text { maris and chert }\end{array}$ & & $303.3-320.0$ & 16.7 & $\begin{array}{l}418 \mathrm{~A}-13-2,80 \mathrm{~cm} \text { to } \\
418 \mathrm{~A}-14, \mathrm{CC}\end{array}$ & $\begin{array}{c}301.6-319.5^{e} \\
\quad(311.1)\end{array}$ & $\begin{array}{l}18.1 \\
(9.5)\end{array}$ & $\begin{array}{l}418 \mathrm{~B}-33-1,60 \mathrm{~cm} \text { to } \\
418 \mathrm{~B}-34-1,60 \mathrm{~cm}\end{array}$ \\
\hline VIII & Gray nannofossil chalk & Lower Aptian & $\begin{array}{c}323.8-324.0^{e} \\
\text { or } \\
(320.0-320.2)\end{array}$ & $\begin{array}{l}20 \mathrm{~cm} \text { recovered } \\
\text { above basalt }\end{array}$ & $418 \mathrm{~A}-15-1,0-20 \mathrm{~cm}$ & & $\begin{array}{l}\text { Not } \\
\text { recovered }\end{array}$ & \\
\hline IX & $\begin{array}{l}\text { Basalt with interpillow } \\
\text { limestone }\end{array}$ & & & & & & & \\
\hline
\end{tabular}

${ }_{b}^{a}$ Core 1 at Hole 418 : no coring until 111 meters at Hole $418 \mathrm{~A}$.

${ }^{b}$ No coring prior to 111 meters.

$c_{\text {Washed intervals }}=177.5-196.5=19$ meters: $206-234.5=28.5$ meters .

Washed after 244.0 to $272.5=28.5$ meters.

'Based on driller's depth to basalt. 
moderately well-preserved, and suitable for biostratigraphic zonation only in the Eocene siliceous oozes (Bukry, 1980). Calcareous nannofossils are absent throughout except in the uppermost core and in the basal Cretaceous sediments (Gartner, 1980: Siesser, 1980). According to nannofossil stratigraphy, holes 417D, 418A, and 418B all have the same basement age of Early Aptian but have significantly different early- to mid-Cretaceous sequences. Pleistocene nannofossils were probably transported to this site via turbidity currents. Ichthyolith stratigraphy in sections barren of other fossil groups suggests late Cenozoic accumulation rates of 3-5 mm/1000 yrs (Kozarek and Orr, 1980). Most palynomorphs of middle Cretaceous sediments are of marine origin (Hochuli and Kelts, 1980). At this time, phytoplankton assemblages underwent rapid, fundamental changes in response to significant short-term changes in basinwide paleo-oceanography.

Physical Properties

Donnelly et al. (1980) present measurements made onboard ship of sedimentary wet-bulk density, compressional wave velocity, shear strength, water content and porosity (Figure 14). At Site 417, they concluded that drilling disturbance and removal of samples from in-situ pressure-temperature conditions affected most samples. As a result, the only reliable changes with depth are a shear strength gradient change at $\sim 70 \mathrm{~m}$ and impedance contrasts at $280 \mathrm{~m}$ and $310 \mathrm{~m}$ depth in Hole 417D. Logging confirmed only the feature at 310 m (Salisbury et al., 1980a; see logging section below). Richards and Fager (1980) made measurements onshore of engineering properties on sediments from the upper $140 \mathrm{~m}$ of Hole 417A. At Site 418, Donnelly et al. (1980) concluded that the only significant variations in physical properties were an increase in velocity and shear strength near $190 \mathrm{~m}$ depth and an impedance change coincident with chert layers at $235 \mathrm{~m}$ depth. From the latter, they predicted a prominent reflection $\sim 0.1 \mathrm{sec}$ above basement. During ODP Leg 102 logging of Hole 418A, the only physical property log which gave satisfactory results in the sediment section was the gamma ray neutron porosity (Shipboard Scientific Party, 1986; Carlson et al., 1988b). 

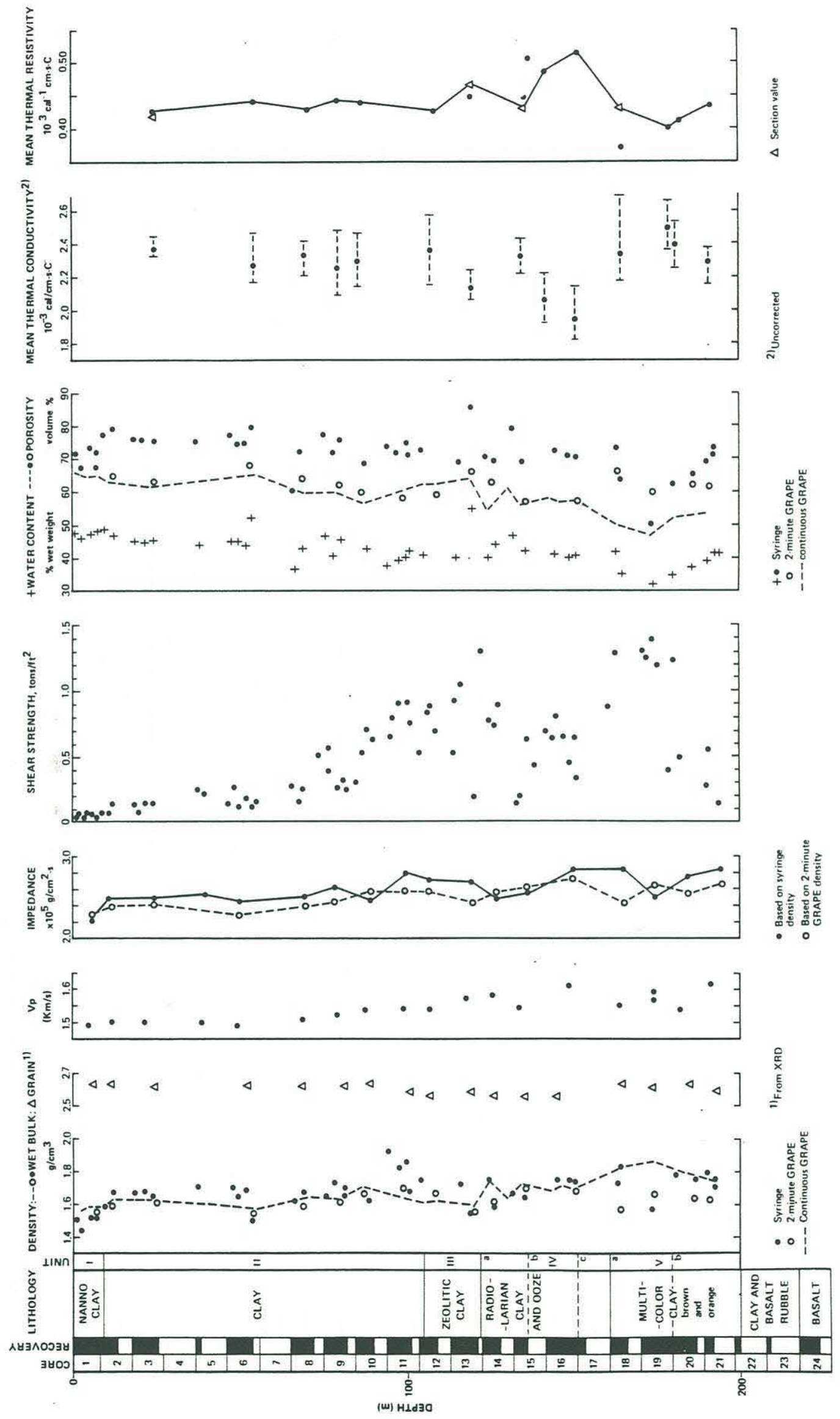

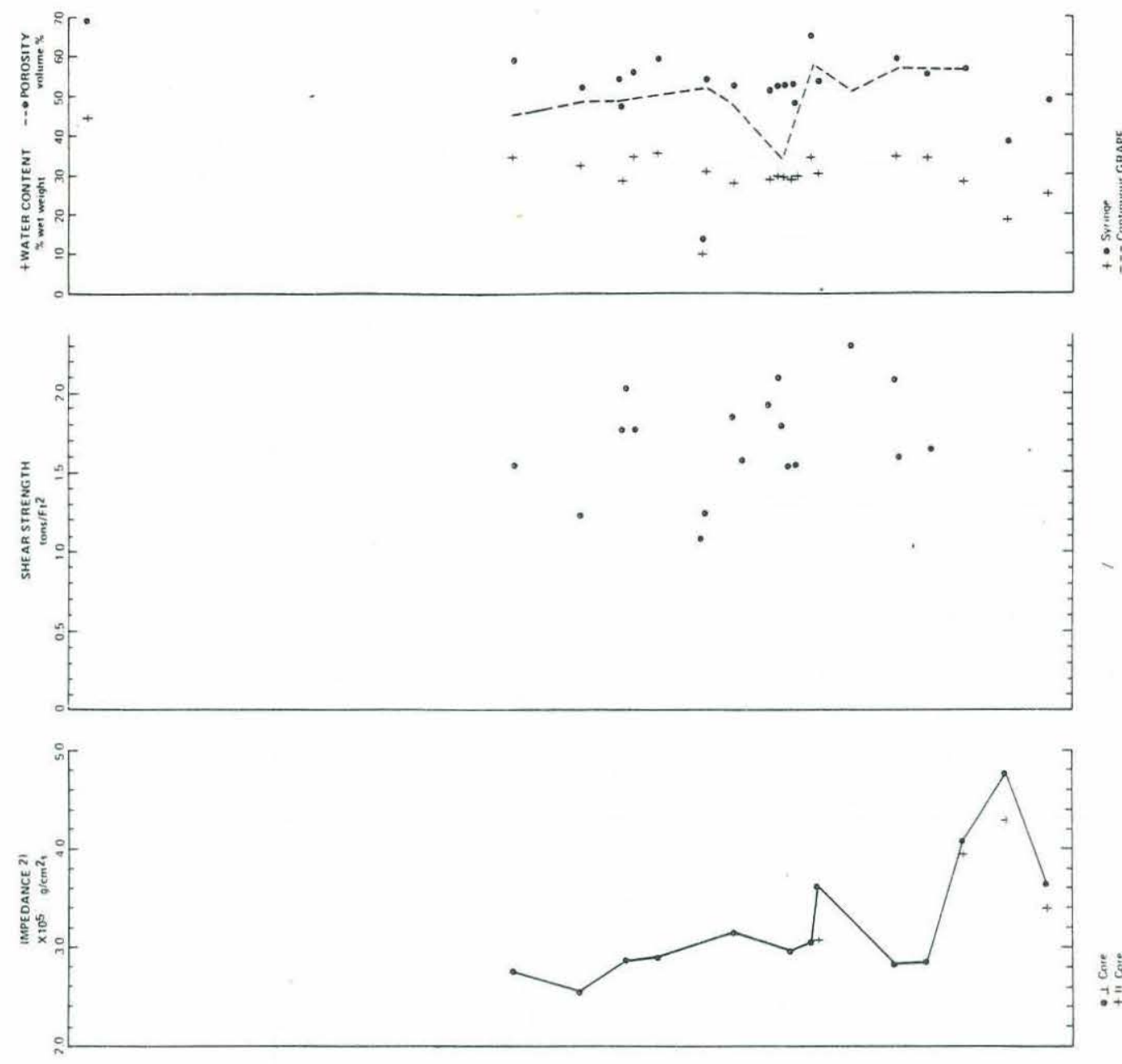

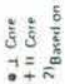

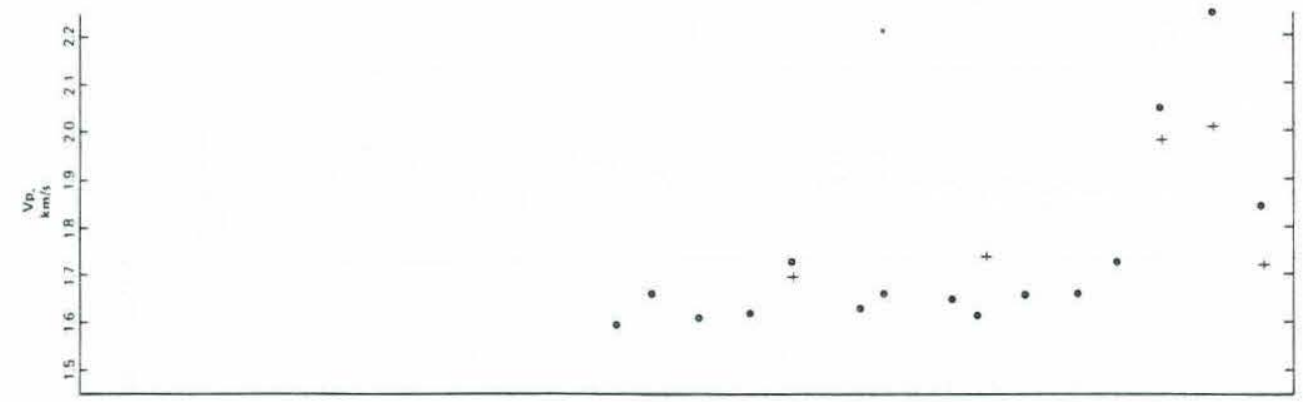

if
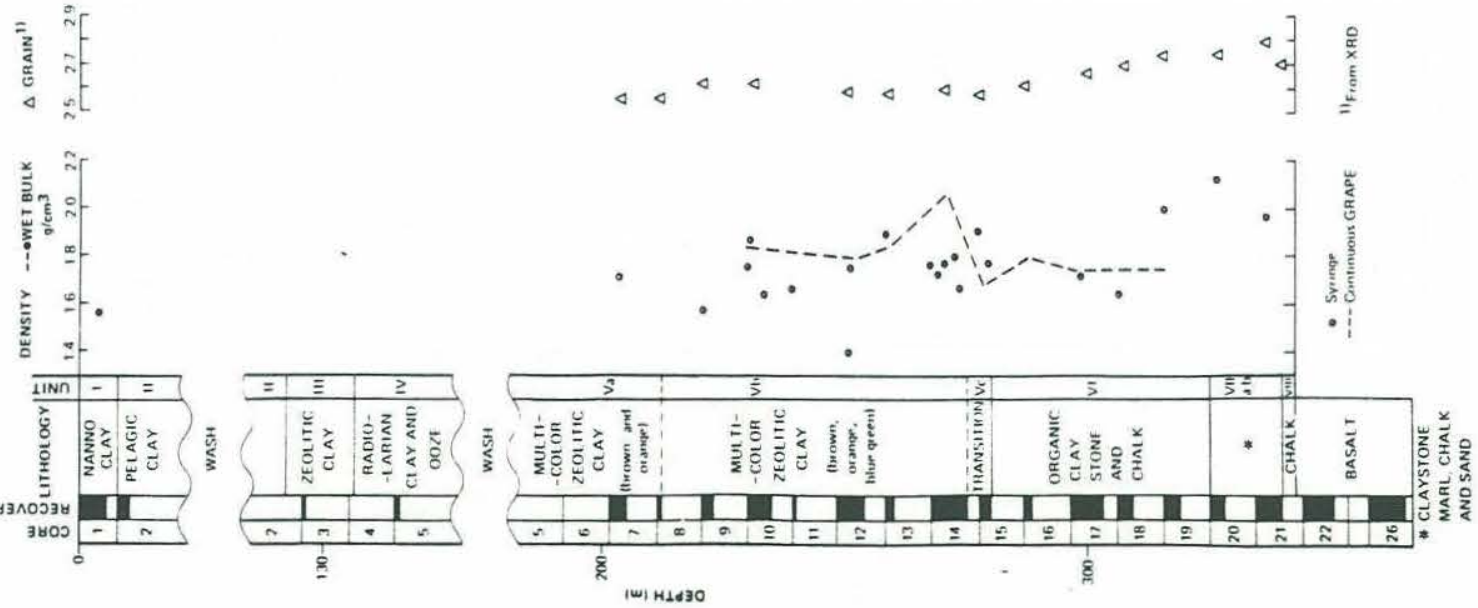


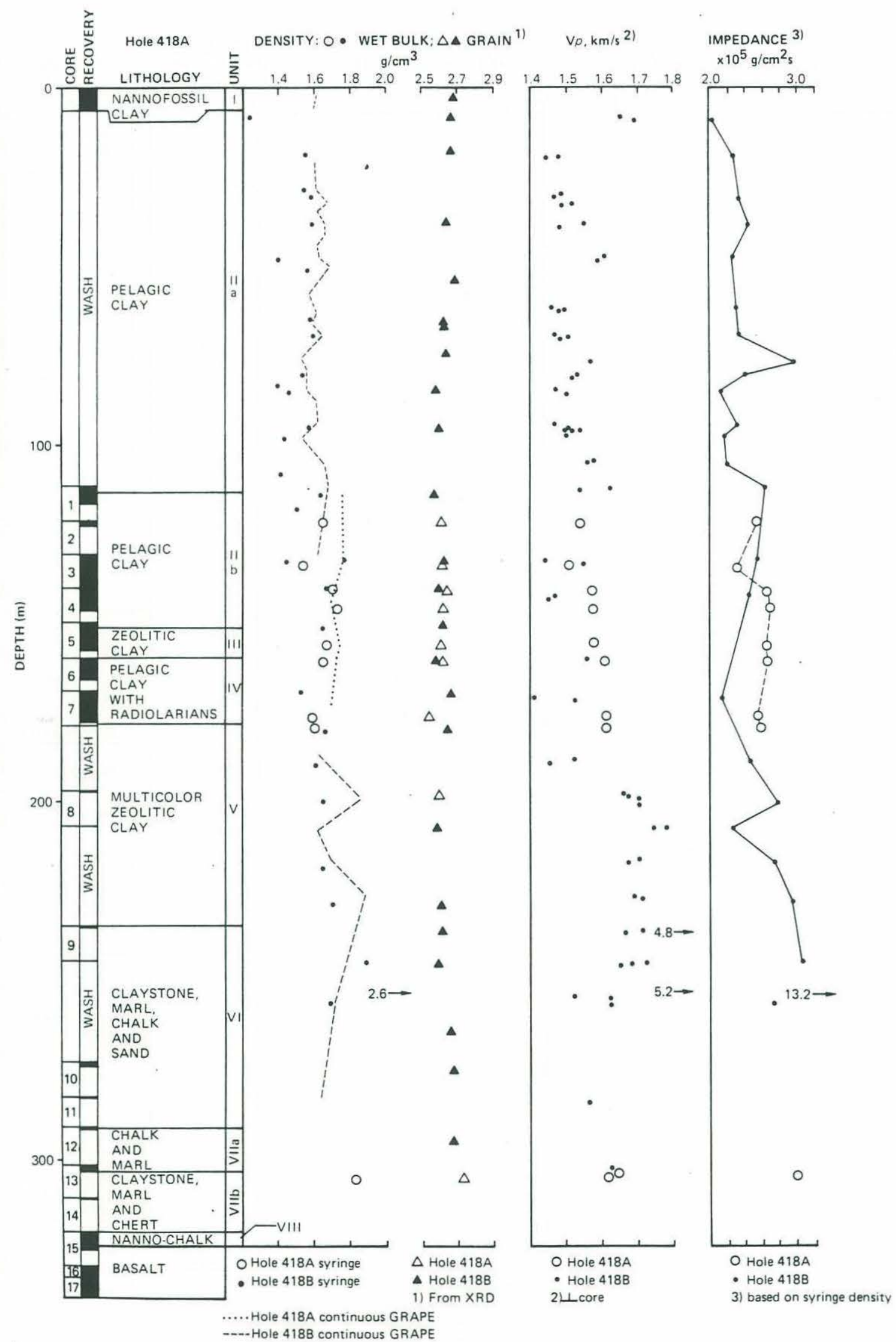

Holes 418A and 418B: Physical properties of sediment. 


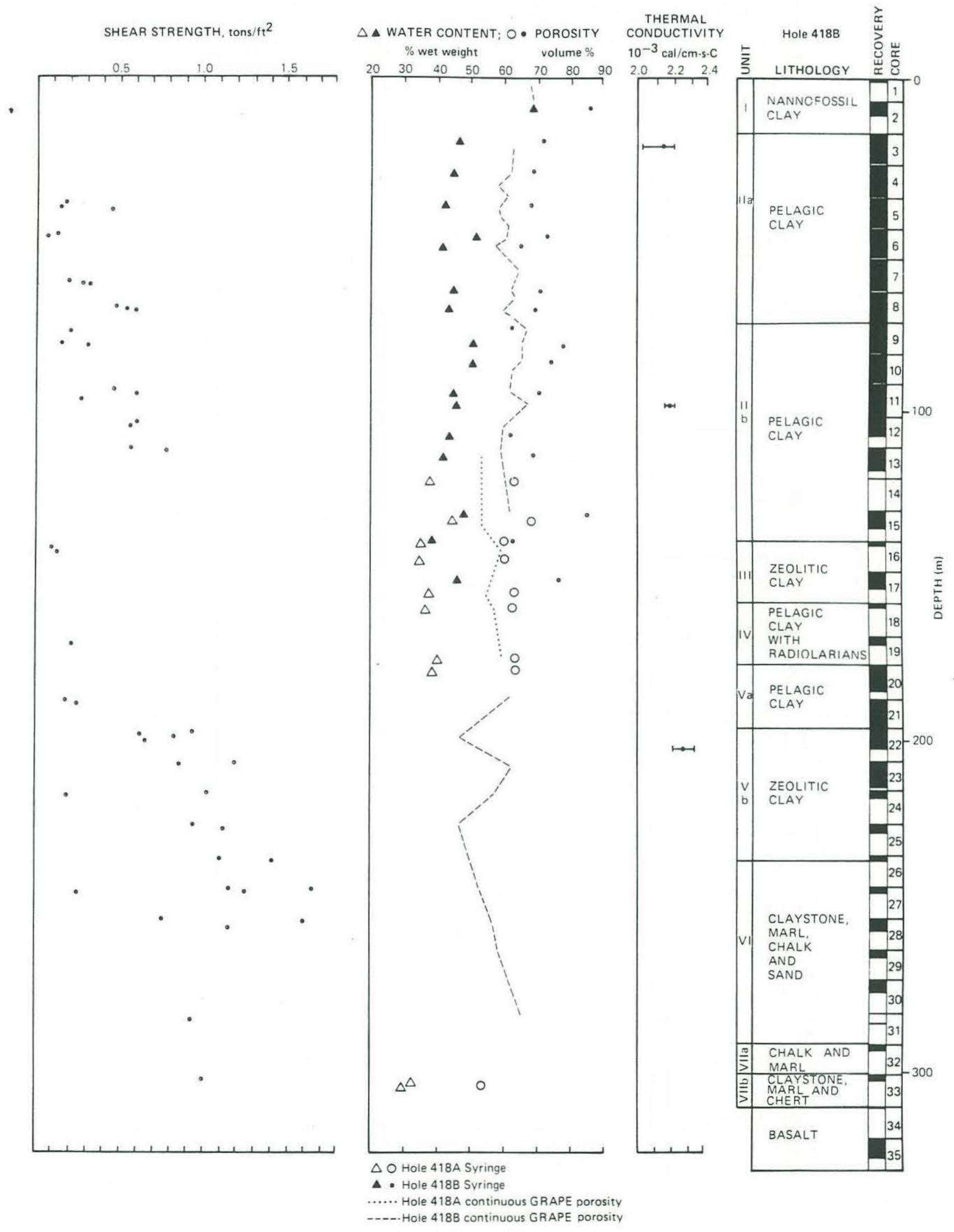




\section{BOREHOLE BASEMENT STUDIES}

Donnelly et al. (1980) present detailed descriptions of basement rock cored on DSDP Legs 51, 52, and 53. Penetration was deeper than most other Atlantic boreholes (417A - 206 m, 417D - 365.5 m, 418A - 544 m). Recovery rates were exceptionally high averaging $62 \%$ in $417 \mathrm{~A}, 75 \%$ in $417 \mathrm{D}, 72 \%$ in $418 \mathrm{~A}$ (Table 1). Figure 15 schematically shows basement lithostratigraphy for both sites. One of the remarkable results of drilling these holes is the relative "freshness" of basement rock recovered at Holes 417D and 418A, although some degree of low temperature alteration is pervasive. In particular, unaltered basaltic glass was recovered. Study of these holes has greatly improved our understanding of the petrology and chemistry of old Atlantic crust. Another remarkable result was the high degree to which Hole 417A rocks, recovered from a basement high, were altered by low-temperature reactions. These rocks are significant because they demonstrate lateral variability in basalt chemistry and alteration processes in the crust, and because the change in chemistry from fresh Hole 417D rocks to Hole 417A rocks can be used to estimate fluxes of elements between crustal rocks and overlying seawater.

\section{Lithostratigraphy}

Below the sediment-basement contact the major rock types are pillow basalts, massive flow basalts, and breccias. Sediment interbeds and intrusive dikes are minor components. Tables 6-8 give depths to lithostratigraphic unit boundaries. Table 9 lists the relative proportions of each lithology.

Pillows are probably flattened slightly with vertical thickness averaging $\sim 50 \mathrm{~cm}$ and ranging from 10-150 cm (Robinson et al., 1980). Average pillow size is slightly lower at Hole 417A. The outer 1-2 cm margin of pillows are glassy and cut by concentric fractures. The phenocryst concentration within most pillows is uneven and variable. Thicknesses of pillow units (often with minor, inter-pillow breccia) range up to $65 \mathrm{~m}$ at Site 417 and 
Figure 15. Basement lithostratigraphy at the four holes which penetrated basement. Compiled from Donnelly et al. (1980).

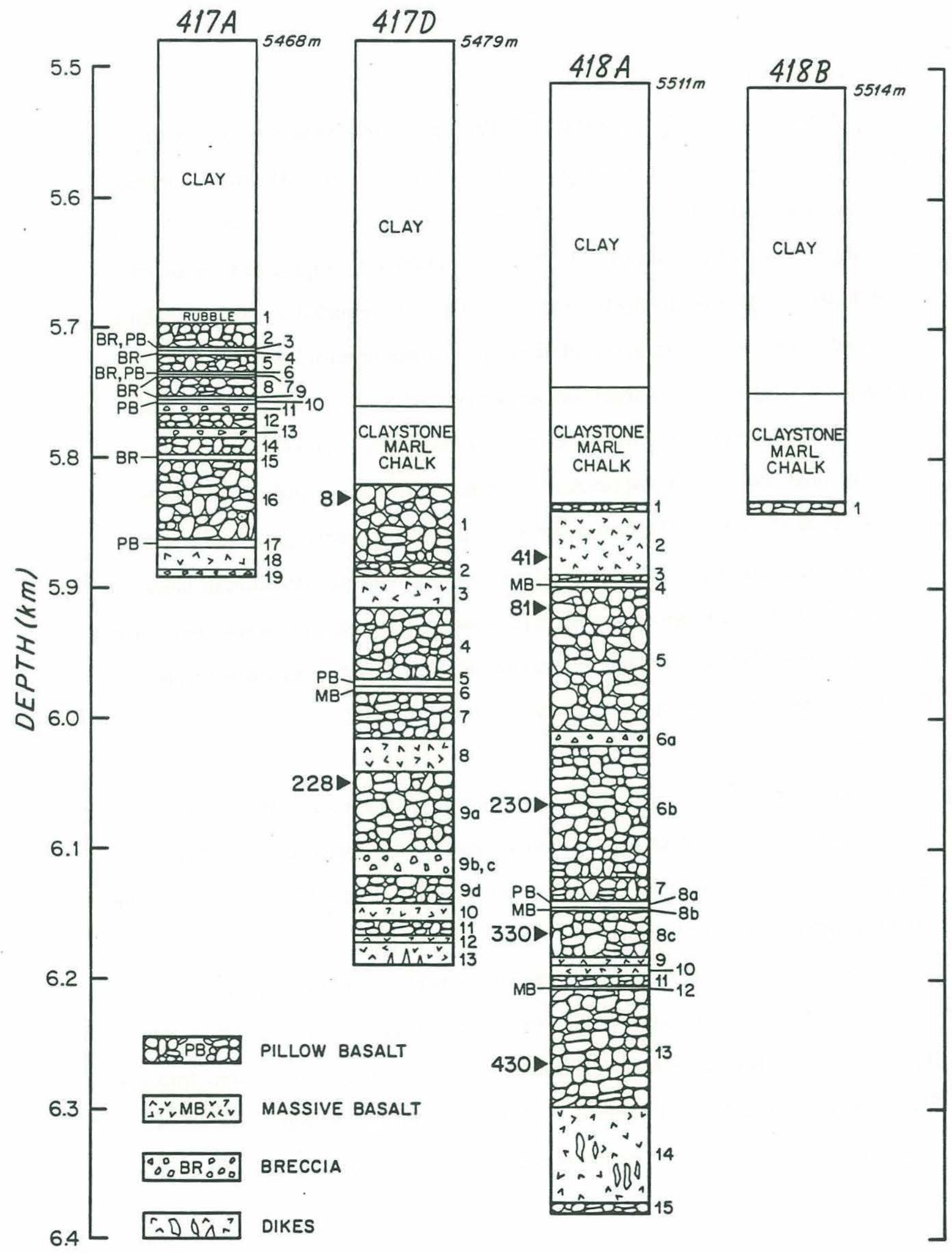


Table 6. From Donnelly et al. (1980)

Basement Lithologic Units, Hole 417 A

\begin{tabular}{|c|c|c|c|c|c|c|}
\hline Unit & $\begin{array}{l}\text { Topa } \\
(\mathrm{m})\end{array}$ & $\begin{array}{l}\text { Basea }^{\mathrm{a}} \\
(\mathrm{m})\end{array}$ & $\begin{array}{l}\text { Thickness } \\
(\mathrm{m})\end{array}$ & $\begin{array}{c}\text { Type Cooling } \\
\text { Unit }\end{array}$ & $\begin{array}{l}\text { Phenocryst } \\
\text { Assemblage }\end{array}$ & $\begin{array}{c}\text { Sample } \\
\text { (Core-Section, } \\
\text { Interval in } \mathrm{cm} \text { ) }\end{array}$ \\
\hline $1 \mathrm{~A}$ & 208.0 & 208.8 & 0.8 & Pebbles & Plag-Oliv & $23-1,80$ \\
\hline $1 \mathrm{~B}$ & 217.5 & 218.8 & 1.3 & Pillow basalt & Plag-Oliv & $24-1, \quad 0$ to $24-1,130$ \\
\hline $2 \mathrm{~A}$ & 218.8 & 220.1 & 1.3 & Breccia & Plag-Oliv & $24-1,130$ to $24-2,110$ \\
\hline $2 \mathrm{~B}$ & 220.1 & 237.2 & 17.2 & Pillow basalt & Plag-Oliv & $24-2,110$ to $26-1, \quad 75$ \\
\hline $3 \mathrm{~A}$ & 237.3 & 237.5 & 0.2 & Breccia (thin) & Plag-Oliv & $26-1, \quad 75$ to $26-1, \quad 95$ \\
\hline $3 \mathrm{~B}$ & 237.5 & 238.8 & 1.3 & Pillow basalt & Plag-Oliv & $26-1, \quad 95$ to $26-2, \quad 75$ \\
\hline \multirow[t]{2}{*}{4} & 238.8 & 243.4 & 4.6 & Breccia & Plag-Oliv & $26-2, \quad 75$ to $26-5, \quad 85$ \\
\hline & & (include & $0.5 \mathrm{~m}$ of bas & $t$ between 240.6 & $41.2 \mathrm{~m}$ in Core $26-3$, & $105 \mathrm{~cm}$ to $26-4,15 \mathrm{~cm}$ ) \\
\hline 5 & 243.4 & 255.5 & 12.1 & Pillow basalt & Plag-Oliv & $26-5,85$ to $28-1, \quad 0$ \\
\hline $6 \mathrm{~A}$ & 255.5 & 255.9 & 0.4 & Breccia & Plag-Oliv & $28-1, \quad 0$ to $28-1,40$ \\
\hline $6 \mathrm{~B}$ & 255.9 & 257.4 & 1.5 & Pillow basalt & Plag-Oliv & $28-1, \quad 40$ to $28-2, \quad 35$ \\
\hline 7 & 257.4 & 258.5 & 1.1 & Breccia & Plag-Oliv & $28-2, \quad 35$ to $28-2,150$ \\
\hline 8 & 258.5 & 274.5 & 16.0 & Pillow basalt & Plag-Oliv & $28-3, \quad 0$ to $29-7, \quad 45$ \\
\hline 9 & 274.5 & 277.2 & 2.7 & Breccia & Plag-Oliv & $30-1, \quad 0$ to $30-2,115$ \\
\hline 10 & 277.5 & 279.8 & 2.3 & Pillow basalt & Plag-Oliv & $30-3, \quad 0$ to $30-4, \quad 75$ \\
\hline \multirow[t]{2}{*}{11} & 279.8 & 288.0 & 8.2 & Breccia & Plag-Oliv & $30-4, \quad 75$ to $31-3,100$ \\
\hline & & & $1.0 \mathrm{~m}$ of bas & $t$ between 282.9 & $84.8 \mathrm{~m}$ in Cores $30-6$ & $, 90$ to $31-1,75)$ \\
\hline 12 & 288.0 & 298.8 & 10.8 & Pillow basalt & Plag-Oliv $\pm \mathrm{Cpx}$ & $31-3,100$ to $32-4,80$ \\
\hline \multirow[t]{2}{*}{13} & 298.8 & 306.1 & 7.3 & Breccia & Plag-Cpx-Oliv & $32-4, \quad 80$ to $33-3, \quad 50$ \\
\hline & & (include & $.7 \mathrm{~m}$ of basa & between 303.0 & $3.7 \mathrm{~m}$ in Core $33-1, \mathrm{c}$ & $\mathrm{cm}$ to $33-1,70 \mathrm{~cm}$ ) \\
\hline 14 & 306.1 & 319.5 & 13.4 & Pillow basalt & Plag-Cpx-Oliv & $33-3, \quad 5$ to $34-5,100$ \\
\hline 15 & 319.5 & 322.7 & 3.2 & Breccia & Plag-Cpx-Oliv & $34-5,100$ to $35-1,65$ \\
\hline $16 \mathrm{~A}$ & 322.7 & 353.6 & 30.9 & Pillow basalt & Plag-Cpx-Oliv & $35-1, \quad 65$ to $38-5,80$ \\
\hline $16 \mathrm{~B}$ & 353.5 & 364.3 & 10.8 & Pillow basalt & Plag-Cpx-Oliv & $38-5,80$ to $40-1,90$ \\
\hline $16 \mathrm{C}$ & 364.3 & 379.7 & 15.4 & Pillow basalt & Plag-Cpx-Oliv & $40-1, \quad 90$ to $42-1, \quad 75$ \\
\hline 16D & 379.7 & 385.6 & 5.9 & Pillow basalt & Plag-Cpx-Oliv & $42-1, \quad 75$ to $42-5,105$ \\
\hline $17 \mathrm{~A}$ & 385.6 & 385.7 & 0.1 & Breccia & Plag-Cpx-Oliv & $42-5,105$ to $42-5,125$ \\
\hline $17 \mathrm{~B}$ & 385.7 & 389.9 & 4.2 & Pillow basalt & Plag-Cpx-Oliv & $42-6, \quad 0$ to $43-2, \quad 0$ \\
\hline & 389.9 & 394.7 & 4.8 & Massive basalt & Plag-Cpx-Oliv & 0 to $44-1,25$ \\
\hline \multirow[t]{2}{*}{$18 \mathrm{~B}$} & 394.8 & 407.9 & 13.1 & Massive basalt & Plag-Cpx-Oliv & $44-1,25$ to $46-1, \quad 40$ \\
\hline & & & thin veined & & $\mathrm{cm}$ to $44-1,40 \mathrm{~cm}$ ) & \\
\hline 19 & 407.9 & 412.8 & 4.9 & Breccia & Plag-Cpx-Oliv & $46-1, \quad 40$ to $46-4,80$ \\
\hline
\end{tabular}

${ }^{a}$ Depths corrected for spacers. 
Table 7. From Donnelly et al. (1980)

Basement Lithologic Units, Hole 417D

\begin{tabular}{|c|c|c|c|c|c|c|}
\hline $\begin{array}{l}\text { Unit/ } \\
\text { Sub-Unit }\end{array}$ & $\begin{array}{l}\text { Topa } \\
(\mathrm{m})\end{array}$ & $\begin{array}{c}\text { Base }^{a} \\
(\mathrm{~m})\end{array}$ & $\begin{array}{l}\text { Thickness } \\
(\mathrm{m})\end{array}$ & $\begin{array}{l}\text { Type Cooling } \\
\text { Unit }\end{array}$ & $\begin{array}{l}\text { Phenocryst } \\
\text { Assemblage }\end{array}$ & $\begin{array}{c}\text { Sample } \\
\text { (Core-Section, Interval in } \mathrm{cm} \text { ) }\end{array}$ \\
\hline $1 \mathrm{~A}$ & 343 & 367.3 & 24.3 & Pillow basalt & Plag-Oliv & $21 \mathrm{CC}, 46$ to $27-1,75$ \\
\hline 1B & 367.3 & 384.8 & 17.5 & Pillow basalt & Plag-Oliv-(Cpx) & $37-1, \quad 75$ to $28-7, \quad 98$ \\
\hline 1C & 384.8 & 407.5 & 22.7 & Pillow basalt & Plag-Oliv-(Cpx) & $29-1, \quad 0$ to $31-3,148$ \\
\hline 2 & 407.5 & 412.8 & 5.3 & Pillow basalt & Plag-Oliv-(Cpx) & 0 to $32-1, \quad 66$ \\
\hline 3 & 412.8 & 435.4 & 22.6 & Massive basalt & Plag-Cpx-Oliv & $32-1, \quad 66$ to $34-5,112$ \\
\hline 4 & 435.4 & 488.4 & 53.0 & Pillow basalt & Plag-Oliv-Cpx & $34-5,112$ to $42-3,75$ \\
\hline 5 & 488.4 & 495.0 & 6.6 & Pillow basalt & Plag-Oliv-Cpx & $42-3,75$ to $43-1,127$ \\
\hline 6 & 495.0 & 500.6 & 5.6 & Massive basalt & Plag-Oliv-Cpx & $43-1,127$ to $43-5,127$ \\
\hline 7 & 500.6 & 538.0 & 37.4 & Pillow basalt & Plag-Oliv-Cpx & $43-5,127$ to $47 \mathrm{CC}$ \\
\hline $8 \mathrm{~A}$ & 538.0 & 539.0 & 1.0 & Massive basalt & Plag-Cpx-Oliv & $48-5, \quad 0$ to $48-7, \quad 98$ \\
\hline $8 \mathrm{~B}$ & 539.0 & 562.5 & 23.5 & Massive basalt & Plag-Cpx-Oliv & 0 to $52-4, \quad 27$ \\
\hline $9 \mathrm{~A}$ & 562.5 & 624.0 & 61.5 & $\begin{array}{l}\text { Pillow basalt } \\
\text { and breccia }\end{array}$ & Plag-Cpx-Oliv & $52-4, \quad 27$ to $58-5, \quad 28$ \\
\hline $9 \mathrm{~B}$ & 624.0 & 533.0 & 9.0 & Breccia & Plag-Cpx-Oliv & 0 to $59-7,37$ \\
\hline $9 \mathrm{C}$ & 633.0 & 642.0 & 9.0 & Breccia & Plag-Cpx-Oliv & 0 to $61-1,93$ \\
\hline 9D & 642.0 & 665.8 & 23.8 & Pillow basalt & Plag-Oliv-(Cpx) & 0 to $64-4,127$ \\
\hline $10 \mathrm{~A}$ & 665.8 & 672.6 & 6.8 & Massive basalt & Plag-Oliv & $64-4,127$ to $65-3,64$ \\
\hline $10 \mathrm{~B}$ & 672.6 & 678.0 & 5.4 & Massive basalt & Plag-Oliv & $65-3, \quad 64$ to $65-6,92$ \\
\hline 11 & 678.0 & 687.0 & 9.0 & Pillow basalt & Plag-Oliv & $66-1, \quad 0$ to $66-6,76$ \\
\hline 12 & 687.0 & 694.1 & 7.1 & Massive basalt & Plag-Oliv & 0 to $67-6, \quad 35$ \\
\hline 13 & 694.1 & 708.5 & 14.4 & Massive basalt & Plag-(Oliv) & $67-6, \quad 35$ to $69-2, \quad 38$ \\
\hline $14 \mathrm{~A}$ & & · & & Basalt dike & Plag-Oliv-Cpx & $68-1,120$ to $68-2,55$ \\
\hline $14 B$ & & & & Basalt dike & Plag-Oliv-Cpx & $68-4, \quad 5$ to $68-4, \quad 49$ \\
\hline
\end{tabular}

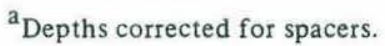


Table 8. From Donnelly et a1. (1980)

Basement Lithologic Units, Hole 418A, from Results of Legs 52 and 53

\begin{tabular}{|c|c|c|c|c|c|c|}
\hline Unit & $\begin{array}{l}\text { Topa } \\
(\mathrm{m})\end{array}$ & $\begin{array}{l}\text { Base }^{\mathrm{a}} \\
(\mathrm{m})\end{array}$ & $\begin{array}{l}\text { Thickness } \\
(\mathrm{m})\end{array}$ & $\begin{array}{l}\text { Type Cooling } \\
\text { Unit }\end{array}$ & $\begin{array}{l}\text { Phenocryst } \\
\text { Assemblage }\end{array}$ & $\begin{array}{c}\text { Intervals } \\
\text { (Core-Section, } \mathrm{cm})\end{array}$ \\
\hline 1 & 324.0 & 329.6 & 5.6 & Pillow basalt & Plag-(Oliv) & $15-1,20$ to $16-1,10$ \\
\hline $2 \mathrm{~A}$ & 329.6 & 331.7 & 2. $\Gamma$ & Massive basalt & Plag-(Oliv) & $16-1,10$ to $16-2,105$ \\
\hline 2B & 331.7 & 339.0 & 7.3 & Massive basalt & Plag-(Oliv) & $16-2,105$ to $17-4,150$ \\
\hline $2 \mathrm{C}$ & 339.0 & 363.1 & 24.1 & Massive basalt & Plag-(Oliv) & $18-1,0$ to $20-5,81$ \\
\hline $2 \mathrm{D}$ & 363.1 & 376.6 & 13.5 & Massive basalt & Plag-(Oliv)- $[\mathrm{Cpx}]$ & $20-5,81$ to $24-1,57$ \\
\hline 3 & 376.6 & 383.3 & 6.7 & Pillow basalt & Plag-(Oliv)- $[\mathrm{Cpx}]$ & $24-1,57$ to $25-2,60$ \\
\hline 4 & 383.3 & 387.1 & 3.8 & Massive basalt & Plag-(Oliv)-[Cpx] & $25-2,60$ to $26-2,110$ \\
\hline 5 & 387.1 & 498.5 & 111.4 & $\begin{array}{l}\text { Pillow basalt and } \\
\text { breccia }\end{array}$ & Plag-(Oliv)-[Cpx] & $26-2,110$ to $40-3,47$ \\
\hline $6 \mathrm{~A}$ & 498.5 & 510.5 & 12.0 & Breccia & Plag-Oliv-(Sp)-[Cpx] & $41-1,0$ to $42-2,150$ \\
\hline $6 \mathrm{~B}$ & 510.5 & 611.0 & 100.5 & Pillow basalt & Plag-Oliv-(Sp)-[Cpx] & $42-3,0$ to $53-3,150$ \\
\hline 7 & 611.0 & 629.2 & 18.2 & Pillow basalt & Plag-Oliv-Cpx & $54-1,0$ to $55-7,70$ \\
\hline $8 \mathrm{~A}$ & 629.2 & 632.9 & 3.7 & Pillow basalt & Plag-Oliv-Cpx & $55-7,70$ to $56-3,45$ \\
\hline $8 \mathrm{~B}$ & 632.9 & 636.3 & 3.4 & Massive(?) ba salt & Play-Oliv-Cpx & $56-3,45$ to $56-5,125$ \\
\hline $8 \mathrm{C}$ & 636.3 & 671.8 & 35.5 & Pillow basalt & Plag-Oliv-Cpx & $56-5,125$ to $60-4,33$ \\
\hline 9 & 671.8 & 676.5 & 4.7 & $\begin{array}{c}\text { Massive, vesicular } \\
\text { basalt }\end{array}$ & Plag & $60-4,33$ to $60-6,66$ \\
\hline 10 & 676.5 & 686.0 & 9.5 & Massive basalt & Plag & $61-1,0$ to 61 bit, 95 \\
\hline 11 & 686.0 & 695.5 & 9.5 & Pillow basalt & Plag-Cpx-Oliv & $62-1,0$ to $63-5,119$ \\
\hline 12 & 695.5 & 698.2 & 2.7 & Massive(?) basalt & Plag-Cpx-Oliv & $64-1,0$ to $64-2,122$ \\
\hline 13 & 698.2 & 786.5 & 88.3 & $\begin{array}{l}\text { Pillow basalt and } \\
\text { breccia }\end{array}$ & Plag-C $\mathrm{px}-$ Oliv & $64-2,122$ to $75-4,150$ \\
\hline $14 \mathrm{~A}$ & 786.5 & 793.6 & 7.1 & Massive basalt & Plag-Cpx-Oliv & $75-5,0$ to $77-1,50$ \\
\hline $14 \mathrm{~B}$ & 793.6 & 821.5 & 27.9 & Massive basalt & Plag-Cpx-Oliv & $77-1,50$ to $79.7,124$ \\
\hline $14 \mathrm{C}$ & 821.5 & 859.8 & 38.3 & Massive basalt & Plag-Cpx-Oliv & $80-1,0$ to $86-1,25$ \\
\hline $15 \mathrm{~A}$ & $-b$ & - & - & Basalt dikes & Plag-O liv-Cpx & $\begin{array}{l}79-1,75 \text { to } 79-1,110 \\
79-2,78 \text { to } 79-2,105 \\
79-3,105 \text { to } 79-4,95\end{array}$ \\
\hline $15 \mathrm{~B}$ & - & - & - & Basalt dikes & Plag-Oliv & $\begin{array}{l}80-2,117 \text { to } 80-3,127 \\
80-4,2 \text { to } 80-4,42 \\
80-4,107 \text { to } 80-5,110\end{array}$ \\
\hline 16 & 859.8 & 868.0 & 8.2 & $\begin{array}{l}\text { Pillow basalt and } \\
\text { breccia }\end{array}$ & Plag-Oliv-Cpx-Sp & $86-1,25$ to $86-6,55$ \\
\hline
\end{tabular}

${ }_{b}^{a}$ Depths corrected for spacers.

${ }^{b}$ Undetermined. 
Table 9. From Robinson et al. (1980)

Lithologic Summary of Holes 417A, 417D, and 418A

\begin{tabular}{|c|c|c|c|c|c|}
\hline \multirow[b]{2}{*}{ Lithology } & \multirow{2}{*}{$\begin{array}{l}\text { Cored } \\
\text { Thickness } \\
(\mathrm{m})\end{array}$} & \multirow{2}{*}{$\begin{array}{l}\text { Recovered } \\
\text { Thickness } \\
(\mathrm{m})\end{array}$} & \multirow[b]{2}{*}{$\begin{array}{l}\text { Percentage } \\
\text { Recovery }\end{array}$} & \multicolumn{2}{|c|}{ Relative Proportions } \\
\hline & & & & $\begin{array}{c}\text { Cored } \\
(\%)\end{array}$ & $\begin{array}{c}\text { Recovered } \\
(\%)\end{array}$ \\
\hline & & Hole 417A & & & \\
\hline Pillowed basalt & 138.63 & 92.05 & 66.4 & 67.3 & 71.8 \\
\hline Basalt breccia & 37.26 & 24.74 & 66.4 & 18.1 & 19.3 \\
\hline Massive basalt & 23.11 & 10.34 & 44.7 & 11.2 & 8.1 \\
\hline Basalt pebbles & 7.0 & 1.05 & 15.0 & 3.4 & 0.8 \\
\hline \multirow[t]{2}{*}{ Total } & 206.00 & 128.18 & 62.2 (av.) & 100.0 & 100.0 \\
\hline & & Hole 417D & & & \\
\hline Pillowed basalt & 253.0 & 179.11 & 70.8 & 69.2 & 67.8 \\
\hline Basalt breccia & 20.5 & 18.80 & 91.7 & 5.6 & 7.1 \\
\hline Massive basalt & 89.0 & 63.71 & 71.6. & 24.4 & 24.1 \\
\hline Sedimentary rock & 2.0 & 1.50 & 75.0 & 0.5 & 0.6 \\
\hline Dikes & 1.0 & 0.93 & 93.0 & 0.3 & 0.4 \\
\hline \multirow[t]{2}{*}{ Total } & 365.5 & 264.05 & 72.2 (av.) & 100.0 & 100.0 \\
\hline & & Hole 418A & & & \\
\hline Pillowed basalt & 366.60 & 252.23 & 68.8 & 67.4 & 64.5 \\
\hline Basalt breccia & 31.15 & 19.89 & 63.9 & 5.7 & 5.0 \\
\hline Massive basalt & 140.70 & 114.22 & 81.18 & 25.9 & 29.2 \\
\hline Sedimentary rock & 0.55 & 0.37 & 67.3 & 0.1 & 0.1 \\
\hline Dikes & 5.00 & 4.62 & 92.4 & 0.9 & 1.2 \\
\hline Total & 544.00 & 391.33 & 71.9 (av.) & 100.0 & 100.0 \\
\hline
\end{tabular}


$110 \mathrm{~m}$ at Site 418. Pillows are believed to form at low rates of lava discharge (Robinson et al., 1980).

Breccia commonly occurs as thin layers associated with the boundaries of lithologic and magmatic units and as minor interpillow accumulations. There are several breccia types. Thin hyaloclastic breccias are predominantly composed of pieces of greenish, glassy pillow margins with minor angular basalt fragments. The most common are thicker breccia units containing broken pillow fragments or lithic basalt pieces. None of the breccias are bedded. All fragments are poorly sorted. Contacts with pillow units are often gradational. These breccias probably formed on flow fronts (Robinson et al., 1980). Breccia units range up to $9 \mathrm{~m}$ at Site 417 and $12 \mathrm{~m}$ at site 418 . No tectonic breccias were positively identified.

Massive basalt units are present at all sites (Table 9). All units contain phenocrysts $(<20 \%)$ and most contain up to $2 \%$ vesicles. One unit, about $18 \mathrm{~m}$ thick, was recovered from near the bottom of Hole 417A. In Hole 417D, six units range from 1 to $24 \mathrm{~m}$ in thickness and occur throughout the section. In Hole 418A, two thick units of 47 and $73 \mathrm{~m}$ are composed of sub-units ( $2-38 \mathrm{~m}$ thick) representing individual flow events, the extent of which are defined by chilled margins or thin highly brecciated zones. By analogy with subaerial Hawaiian eruptions, massive flow units are believed to form on the seafloor when sheet flows pond in local topographic depressions under high discharge rates (Robinson et al., 1980).

Phyric basaltic dikes occur in the basal massive units in Holes 417D and 418A. In 417D, two chemically similar dikes with olivine, plagioclase, and clinopyroxene phenocrysts and fine-grained holocrystalline ground mass occur at $~ 360 \mathrm{~m}$ subbasement. In $418 \mathrm{~A}$, two chemically and mineralogically distinct dikes were found in the deepest massive unit. A plagioclase-olivine-clinopyroxene phyric basaltic dike occurs at $\sim 490 \mathrm{~m}$ subbasement, and a plagioclase-olivine phyric basalt dike occurs at $\sim 500 \mathrm{~m}$. These dikes 
are typically $20-30 \mathrm{~cm}$ wide with glassy margins. They cut vertically through the host rock.

Within basement sequences, sedimentary rocks are less common at Sites 417 and 418 ( $<1 \%$ of recovered material) than at other basement drill sites in the Atlantic (Robinson et al., 1980). Most sedimentary rock is chalk or limestone with minor chert (McKenzie and Kelts, 1980). Layering and fossils are absent, having probably been destroyed by recrystallization. Fresh and altered basaltic glass is common. $\underline{\text { Mineralogy }}$

The basalts are sparsely to moderately phyric with 5-20\% phenocrysts (Donnelly et al., 1980). Plagioclase (5-10\%) and olivine (1-3\%) appear in most samples. Small, rounded clinopyroxene phenocrysts are common but rarely exceed $2 \%$. Spinel appears only rarely as a phenocryst phase in Hole 418A rocks. Most phenocrysts are fresh except olivine which is typically replaced by smectite and calcite. Some plagioclase crystals show early alteration to brown smectite and/or K-feldspar. The site reports in Donnelly et al. (1980) and Flower et al. (1980; our Figures 16 and 17) show phenocryst assemblages in individual units. Ground mass textures range from quenched to fine-grained in pillow lavas, whereas the massive units are fine to medium grained and subophitic.

Microprobe analyses of phenocryst phases are presented in Rice et al. (1980), Ui et al. (1980), Staudigel et al. (1980a), Bollinger and Semet (1980), Clocchiatti (1980), Sinton and Byerly (1980), and Staudigel and Bryan (1981). Sinton and Byerly (1980) and Flower and Robinson (1981a) use these data to infer the crystallization sequences for these rocks and their petrogenesis. Zoning characteristics of plagioclase phenocrysts within one sample suggests mixing of magma types (Rice et al., 1980).

Opaque mineralogy of Site 417 and 418 rocks was studied by Plasse (1980),-Bleil and Smith (1980b), Genkin et al. (1980), and Gitlin (1985). Opaque minerals are dispersed in the basaltic groundmass and usually form less than $5 \%$ of the rock by volume. These minerals include titanomagnetite and ilmenite, the primary magnetic minerals, 


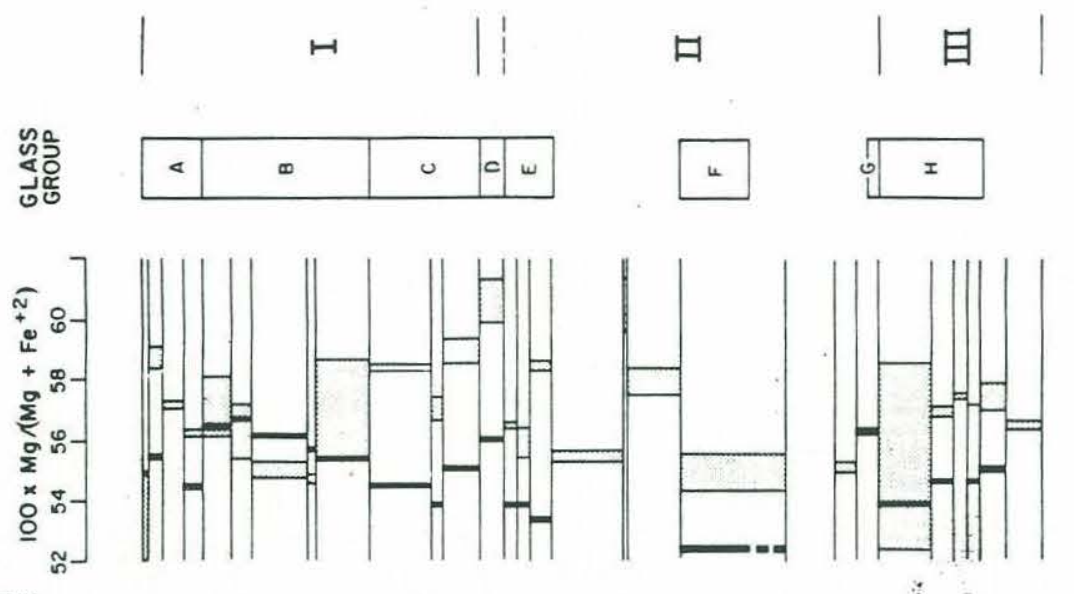

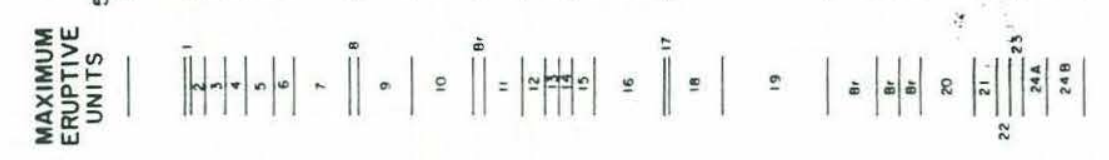
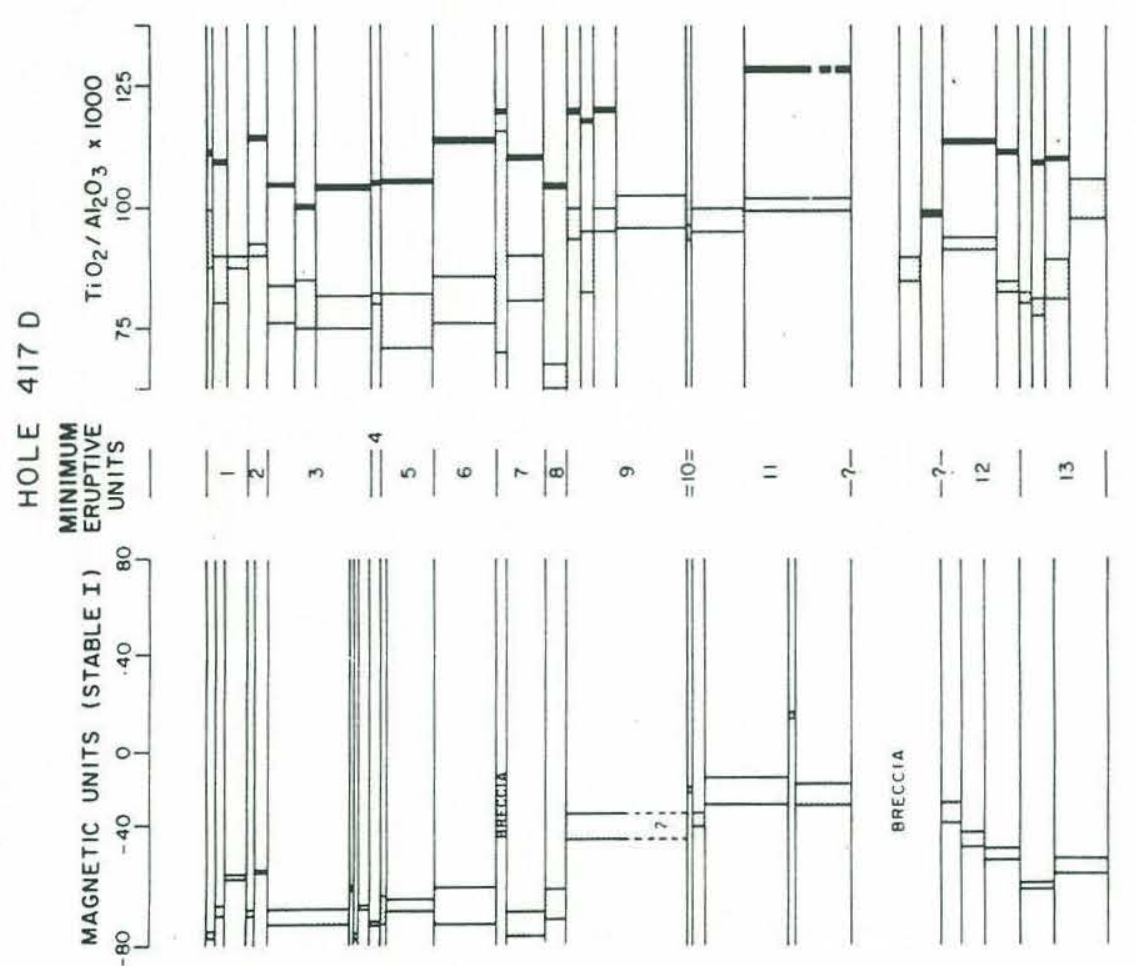

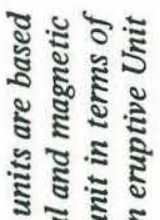

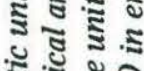

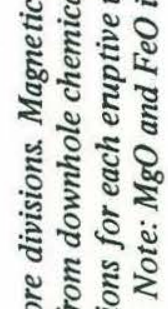

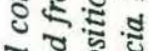

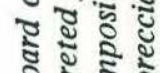

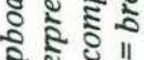

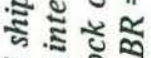
व 20 ธิธี ฐ 골

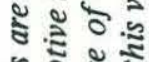

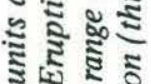

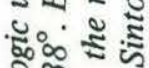
की ㄱำ รัँ ปั ริ:

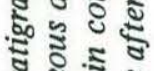
के

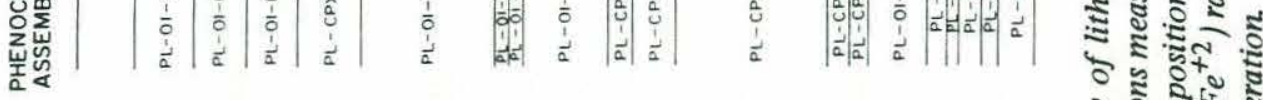

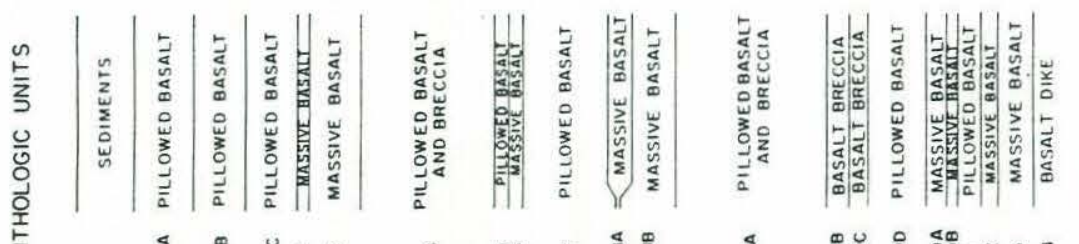

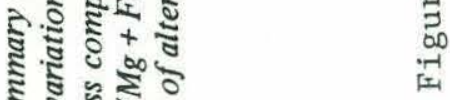



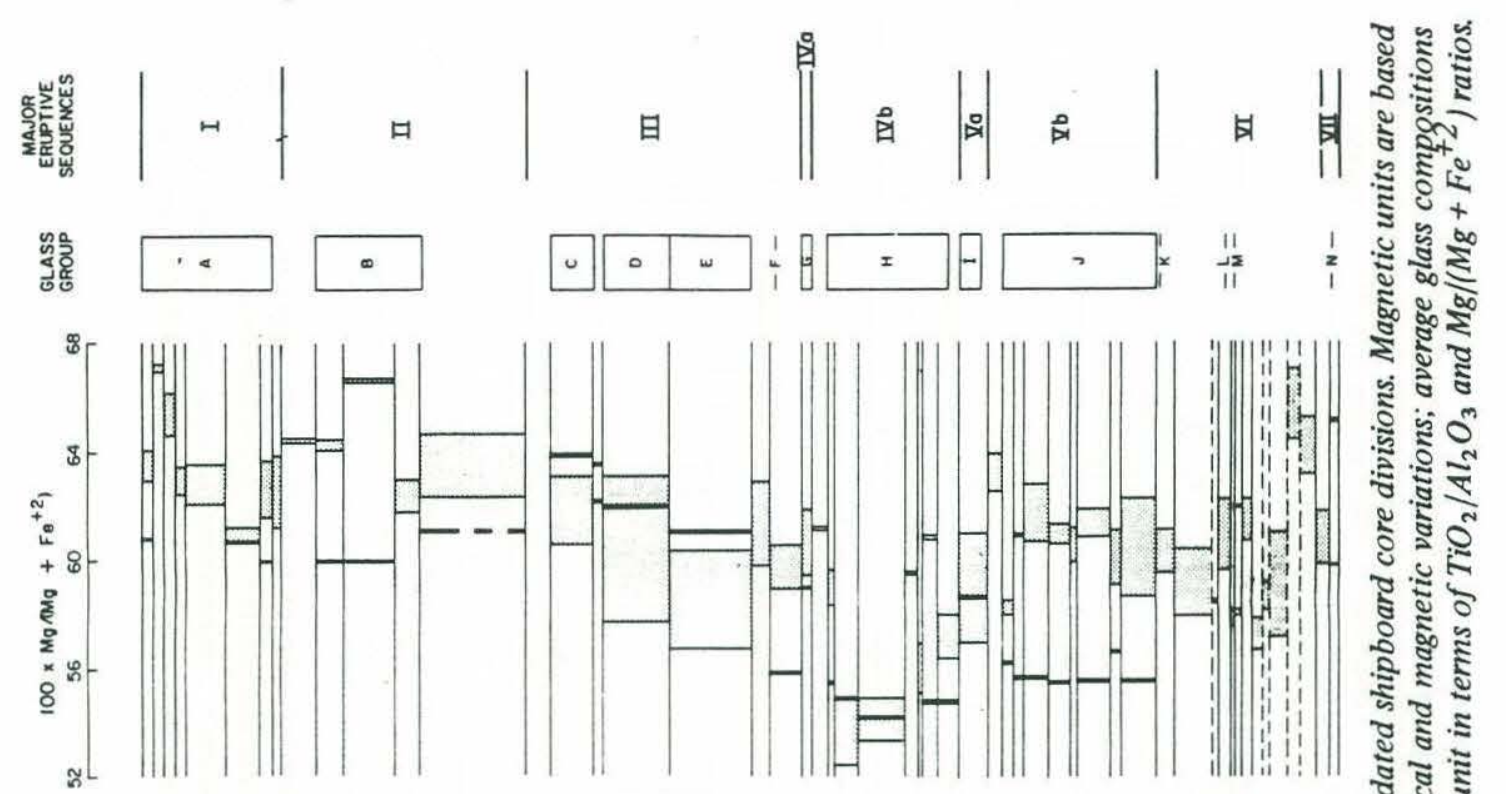

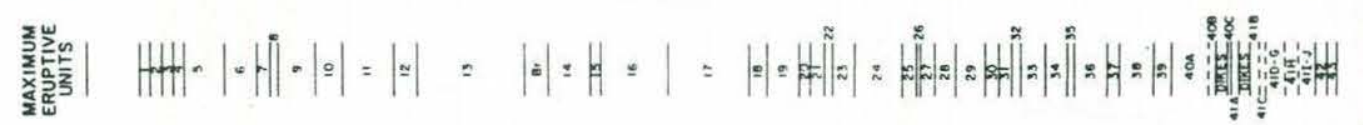

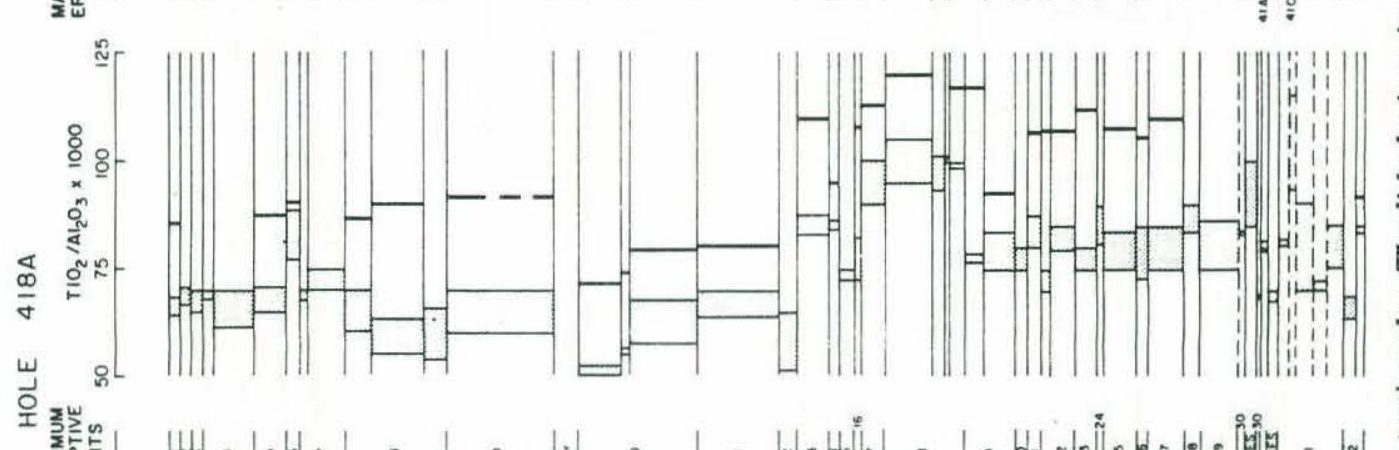

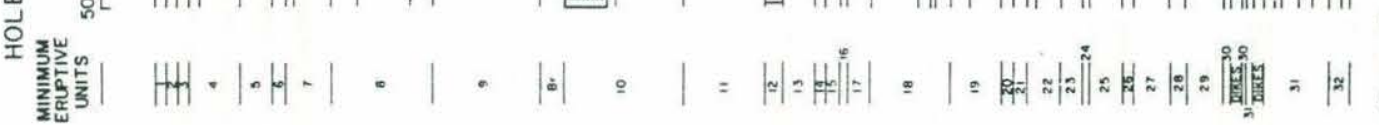

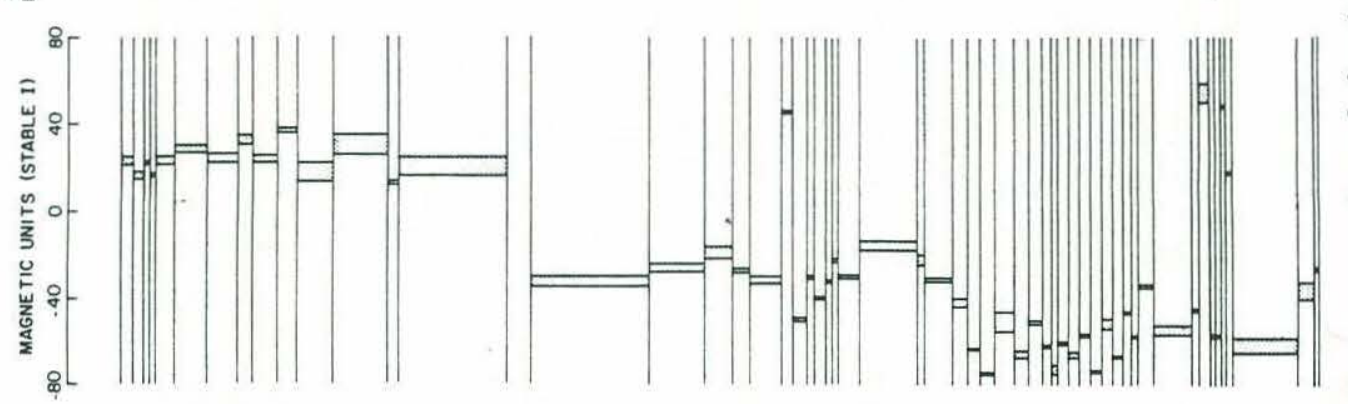

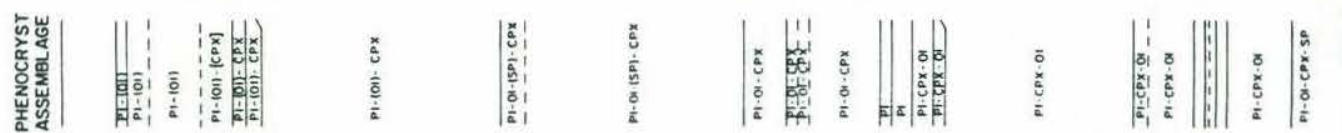

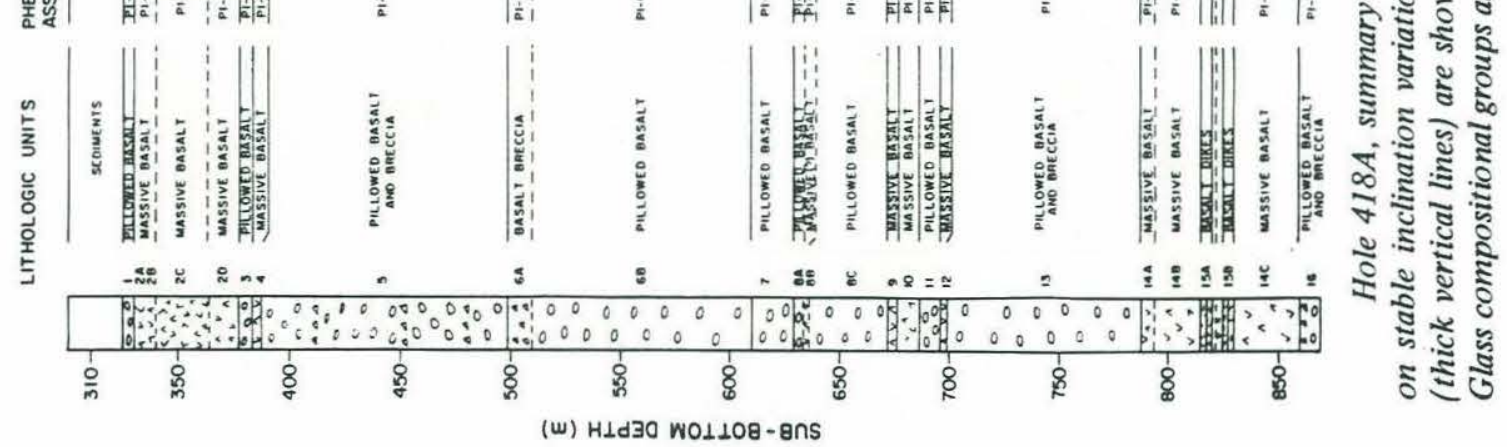


chromite (spinel), pyrite, pyrrhotite, chalcopyrite, and pentlaudite. Plasse (1980) and Bleil and Smith (1980b) show that titanomaghemite, the primary magnetic mineral at Site 417, was unaffected by high-temperature alteration. Ilmenite is present only in massive flow units. Chromium spinel is common only in Unit $6 \mathrm{~b}$ in Hole 418A where it occurs as a rare phenocryst. Pyrite is the most common secondary opaque mineral. .

Except in Hole 417A, alteration products generally do not exceed $20 \%$ of the basalt. Calcite and clay minerals are the main alteration minerals, but quartz, pyrite and some zeolites are present. Oxidation is localized and appears to be confined to cracks and brecciated zones. Hole 417A basalts are pervasively altered with plagioclase replaced by $\mathrm{K}$-feldspar, zeolites, and clay minerals and olivine replaced by "iddingsite", clay minerals, calcite, and iron hydroxide. Clay minerals include smectite and celadonite. Studies of alteration minerals, particularly those from Hole 417A, are summarized below. Geochemistry

Gieskes et al. (1988) sampled borehole fluid in Hole 418A on ODP Leg 102 during the first re-entry. Chemical analyses of major elements and strontium isotope ratios indicate diffusive exchange of basement formation water with borehole fluid. No evidence was found for convective transport.

Several authors have published results of major element chemical analyses of Site 417/418 rocks. A limited number of analyses were performed aboard the GLOMAR CHALLENGER by X-ray fluorescence and published in the site reports (Donnelly et al., 1980). On-shore laboratory analyses provided data sets with larger numbers of analyses and more elements. Microprobe analyses of glass chips were done for Holes 417D, 418A, and 418B by Byerly and Sinton (1980) and for 418A by Thompson (1980) and Mathez (1980). Mathez presents sulfur analyses in addition to the more abundant elements. Whole rock analyses were done for Holes 417D and 418A by Staudigel et al. (1980a), Flower et al. (1980a), and Emmerman and Puchelt (1980). Flower et al. (1980a) also analyzed Hole 417A rocks. Ui et al. (1980) and Rice et al. (1980) analyzed only Site 417 rocks. 
Based on chemical, lithologic, mineralogic, and paleomagnetic properties, the section has been divided into a series of eruptive sequences, each made up of individual units (flows, pillows, etc.) that are related by simple fractional crystalization processes (Figures 16 and 17; Flower et al., 1980a; Robinson et al., 1980; Flower and Robinson, 1981a). These eruptive sequences are 50-200 m thick and comprise from 2 or 3 thick flows up to $\sim 13$ thin flows. Most magnetic property changes coincide with sequence boundaries. Three important conclusions result from these studies: 1) the extrusive rocks were tilted and rotated during emplacement, 2) the eruptive sequences tapped either different magma chambers or tapped a different magma batch from one chamber, and 3) eruption rates declined with time during the emplacement of the entire section.

Basement rocks at Site 417/418 are low-potassium tholeiitic basalts with relatively limited chemical variations (Emmerman and Puchelt, 1980). They closely resemble present Mid-Atlantic Ridge basalts but have greater affinities with rocks recovered from the ridge crest at $37^{\circ} \mathrm{N}$ than at $22^{\circ} \mathrm{N}$ along the tectonic flow line through this site (Byerly and Sinton, 1980). On average, Hole $418 \mathrm{~A}$ basalts have higher $\mathrm{Mg} 0$ and $\mathrm{Ca} 0$ ) and less $\mathrm{Ti}_{2}$, total iron and $\mathrm{Na}_{2} \mathrm{O}$ than 417D basalts (Emmerman and Puchelt, 1980). Trace and rare earth element analyses have been published by Joron et al. (1980, Sites 417 and 418), Rice et al. (1980, Site 417), Shimizu et al. (1980, Site 417 rare earths), Staudigel et al. (1980b, Sites 417 and 418), Flower et al. (1980a, Hole 418A), and Emmerman and Puchelt (1980, Holes 417D and 418A). Basalts from Holes 417D and 418A are depleted in light rare earth elements relative to chondritic compositions. Light rare earth depletion is characteristic of oceanic tholeiites, in general, and all basalts obtained in the western North Atlantic along the tectonic flow line through these sites (Bryan and Frey, 1986). Staudigel et al. (1980b) infer that the mantle source rocks are depleted relative to whole earth (chondritic) composition.

Although most of the observed variation in chemistry can be explained by shallowlevel fractionation of olivine, plagioclase, clinopyroxene and spinel and by post-eruption 
phenocryst movement, multiple parental liquids are required to explain total variation (Byerly and Sinton, 1980; Flower et al., 1980a, b; Flower and Bryan, 1980). The differences in parental liquid chemistry, however, are slight and reflect a relatively uniform mantle source and similar partial-melt conditions. The magmas which fed upper crustal level magma chambers after partial melting in mantle experienced crystallization and separation of olivine before eruption.

Flower and Robinson (1981b) synthesized petrologic, geochemical, and paleomagnetic data from Sites $417 / 418$ and presented a model for crustal formation. They find evidence for episodic eruption of lava with similar but distinct major element compositions, and infer that a steady-state sub-rift magma chamber did not exist. Partial burial of successive eruption events and block rotation produced an imbricate basement sequence with downward increasing structural complexity. Crystal fractionation occurred in two zones, at least: one near the depth of partial melting $(20-30 \mathrm{~km})$ and one just below the rift $(1-2 \mathrm{~km})$.

Hart and Staudigel (1980) and Richardson, et al. (1980) used Rb and Sr ratio measurements on rocks from Holes 417A and 418A to date formation of the crust to $\sim 110$ $112 \mathrm{Ma}$. These results are compared with other dates in the section on age control.

Staudigel et al. (1980b) attribute elevated stroutium ratios $\left({ }^{87} \mathrm{Sr} / 86 \mathrm{Sr}\right.$ $>0.7030$ ) relative to average ocean-ridge basalts as an effect of low-temperature alteration by seawater. Puchelt and Hubberten (1980) found from analyses of sulfur ratios that while most sulfur appears to be derived from the mantle, sulfate phases in some samples show effects of low-temperature alteration. In a small number of samples, Rusinov et al. (1980b) found no downhole variation in carbon and oxygen isotopes from calcite veins. Javoy and Fouillac (1980) measured oxygen, carbon, and hydrogen isotopes in samples from Site 417 . All data indicate low temperature $\left(7^{\circ}\right.$ to $\left.40^{\circ} \mathrm{C}\right)$ alteration of Holes 417D and 417A (twice as much as 417D). Both holes have retained some primary carbon, whereas only Hole 417D has retained primary hydrogen. 
Muehlenbachs (1980) measured oxygen isotopes profiles in Holes 417A, 417D, and $418 \mathrm{~A}$ (e.g. Figure 18). $\delta^{18} \mathrm{O}$ decreases with depth in all holes, reflecting lower degrees of low-temperature alteration by seawater, to values of $\sim 5.8 \mathrm{o} / \mathrm{oo}$, similar to values measured on unaltered mid-ocean ridge basalt. The depth gradient is much steeper in 417 than in the other holes. Samples from breccias and flow margins show the highest $\delta^{18} \mathrm{O}$ values and, by inference, the highest degree of alteration. Muehlenbachs (1980) uses $\delta^{18} \mathrm{O}$ values of carbonate minerals to estimate maximum geothermal gradients of $\sim 9.6^{\circ} \mathrm{C} / 100 \mathrm{~m}$ in $417 \mathrm{~A}$ and $\sim 5^{\circ} \mathrm{C} / 100 \mathrm{~m}$ in $418 \mathrm{~A}$.

Friedrichsen and Hoernes (1980) analyzed Hole 417D and 418A whole rock samples for oxygen and hydrogen isotopes. They did not find the same trend with depth as Muehlenbachs (1980), perhaps as a result of including high $\delta^{18} \mathrm{O}$ values from breccia and flow margins.

Lawrence (1980) measured $\delta^{18} \mathrm{O}$ in samples of calcite veins from Holes $417 \mathrm{~A}$ and 417D. Assuming the precipitating fluid was seawater, he calculates fluid temperatures of $14^{\circ}$ to $41^{\circ} \mathrm{C}$ in good agreement with Javoy and Fouilloc (1980) and Muehlenbachs (1980).

\section{Alteration}

Much has been written on the alteration of rocks recovered at Sites 417 and 418 . The site reports and scientific result chapters contain numerous descriptions of alteration products and inferences about the processes involved. Later papers focused on implications for crustal and seawater chemical budgets.

These rocks at these two sites are noteworthy for two reasons. First, these holes are the oldest, deepest, and best sampled basement sections, in terms of recovery, in slowspreading ocean crust. Second, the dramatic degree of weathering, by all measures, in Hole 417A represents an extreme end product of low-temperature alteration and illustrates, in comparison to fresher rocks at 417D and 418A, a new length scale of heterogeneity in ocean crust with a length scale of $0.5-1.0 \mathrm{~km}$. 
Figure 18. From Muehlenbachs (1980).

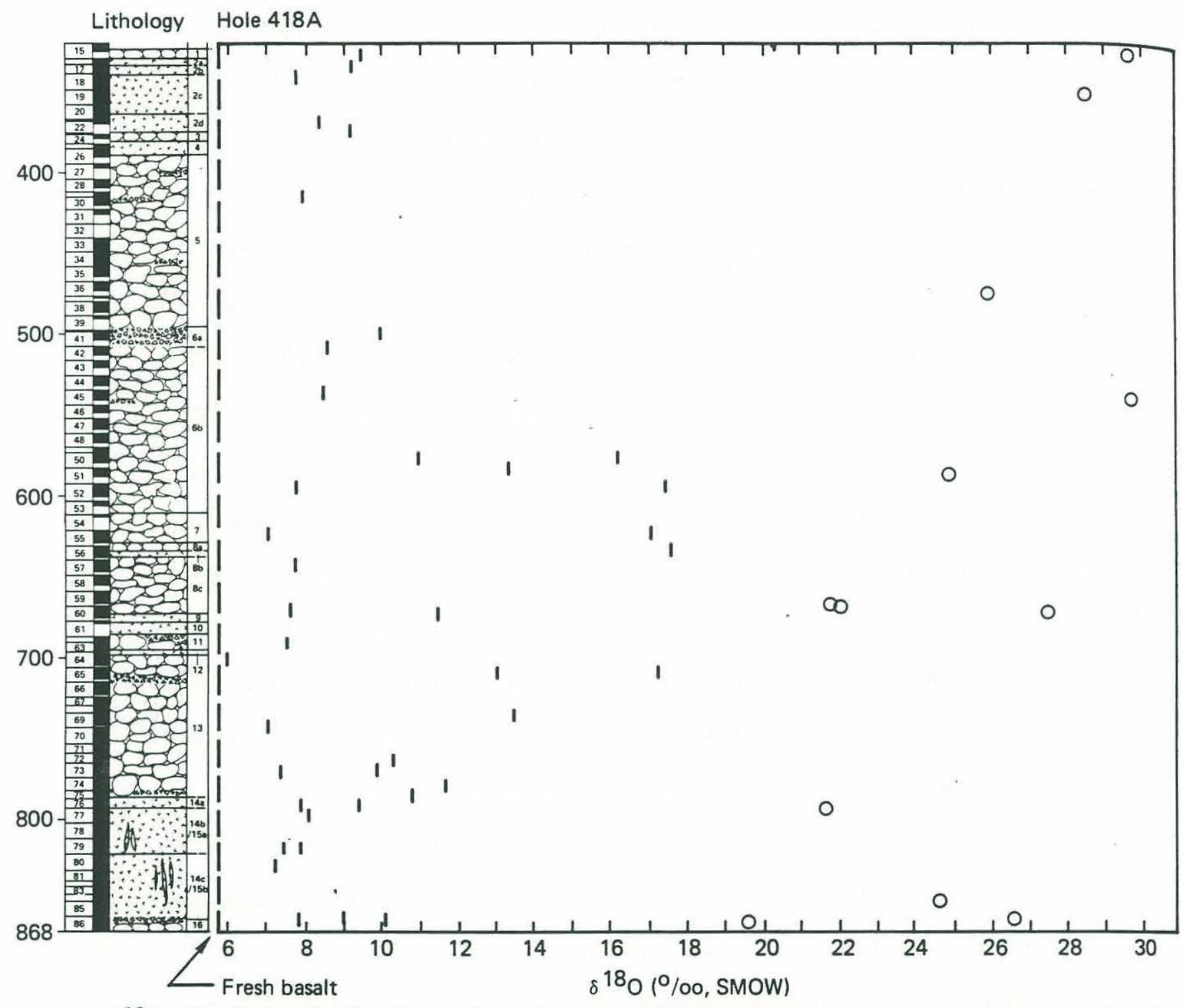

$\delta 180$ of basalts (bars) and carbonates (dots) from Hole $418 \mathrm{~A}$ as a function of depth and lithology. The dashed line at $5.8 \%$ represents the initial $\delta 180$ of unaltered basalts. Note that the most altered basalts are from the breccia zones and unit boundaries. 
Alteration minerals fill veins and vesicles and replace glass and phenocrysts (Prichard, 1980; Humphris et al., 1980; Pertsev and Rusinov, 1980). In upper sections of 417A, groundmass minerals are also replaced. In Holes 417D and 418A, alteration products are most common on pillow margins, between flow units, and in breccias. In 417A, degree of alteration decreases with basement depth (Figures 19 and 20). In 417D and 418A, variations with depth occur, but no overall trend exists (Figure 18).

Alteration products include, in decreasing order of volume, clay minerals, carbonates, K-feldspars, zeolites, silica, iron oxyhydroxide, opaque minerals, and chlorite (Pritchard 1980; Humphris et al., 1980; Pertsev and Rusinov, 1980, Scheidegger and Stakes, 1980; Rusinov et al., 1980a; Juteau et al., 1980, Mevel, 1980; Gitlin, 1985). Figure 21 shows downhole occurrences of alteration minerals noted by Pertsev and Rusinov (1980). In 417A, Fe-K rich celadonite (bright green clay mineral replacing olivine) and a pale green smectite occur. In 418A, olivine is replaced by saponite, an Ferich clay mineral. Plagioclase phenocryst replacement is sometimes incomplete leaving secondary porosity. In $417 \mathrm{~A}, \mathrm{~K}$-feldspar commonly replaces plagioclase, whereas in $418 \mathrm{~A}$ it is common only in the oxidation layers. Calcite is the most common carbonate, but dolomite has been reported as a cavity filling. Zeolites include phillipsite, analcite, and natrolite. In $417 \mathrm{~A}$, hematite, an opaque, hydrous iron-oxide formed under oxidizing conditions, appears throughout the hole. In contrast, the dominant opaque secondary phase in 418A is pyrite, an iron sulfide deposited only under reducing conditions. Pyrite is more common below $\sim 430 \mathrm{~m}$ subbasement. Two local oxidative zones about $70 \mathrm{~m}$ thick occur at $\sim 90 \mathrm{~m}$ and $\sim 343 \mathrm{~m}$ depth.

Holmes (1988) studied the alteration mineralogy of a narrow depth zone in Unit 5 (pillow lavas) in Hole 418A where natural gamma-ray spectrometry logging on ODP Leg 102 found elevated concentrations of potassium. High potassium was observed in two types of alteration products which could be distinguished on the basis of porosity, density and velocity logs. A once-glassy breccia with high porosity, low density, and low velocity 
Figure 19. from Donnelly et a1. (1980b).

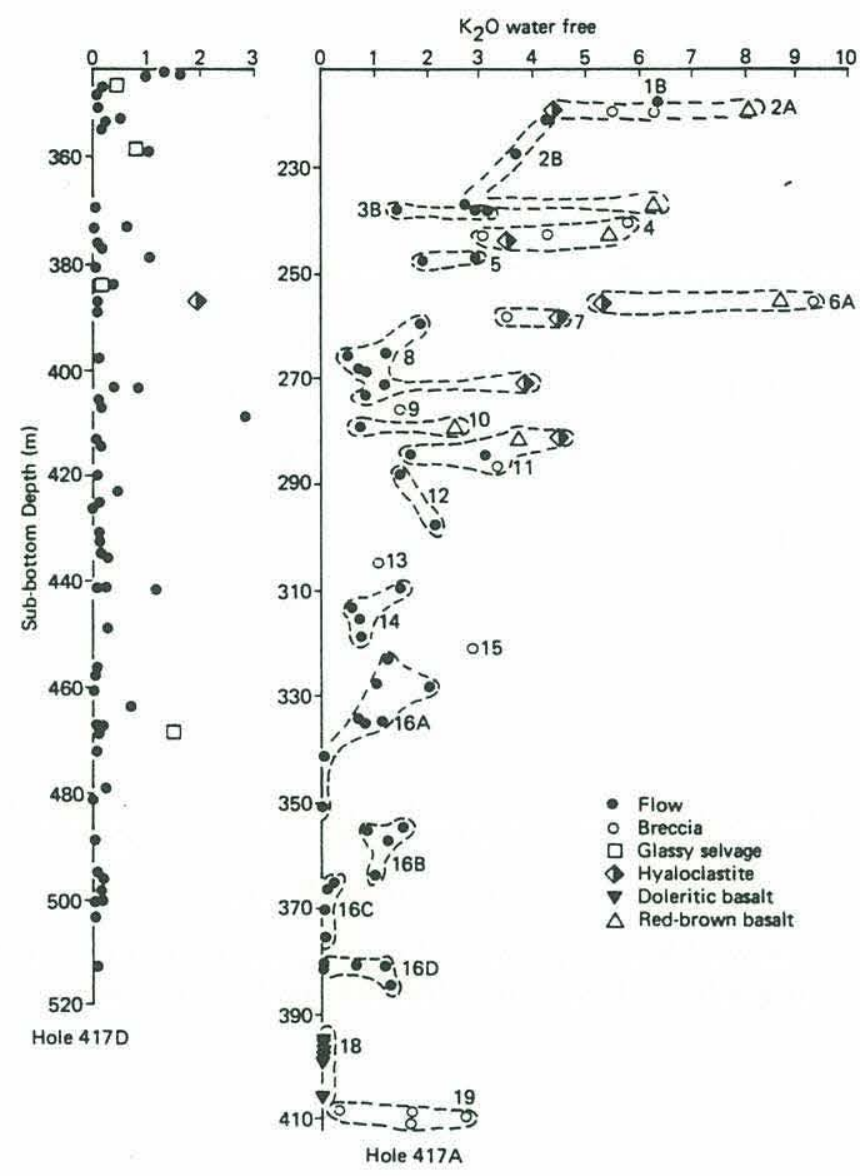

Weight per cent $\mathrm{K}_{2} \mathrm{O}$, calculated on a water-free basis, versus depth in Holes $417 \mathrm{~A}$ and $417 \mathrm{D}$. The tops of the basalt have been matched in position. Lithologic units, as defined in the Site 417 Report (this volume), are circles where more than one sample is given, and identified by italicized number. "Doleritic basalt" refers to massive basalt of Unit 18. 
Figure 20. Oxygen isotope ratio in Hole 417A from Muehlenbachs (1980).

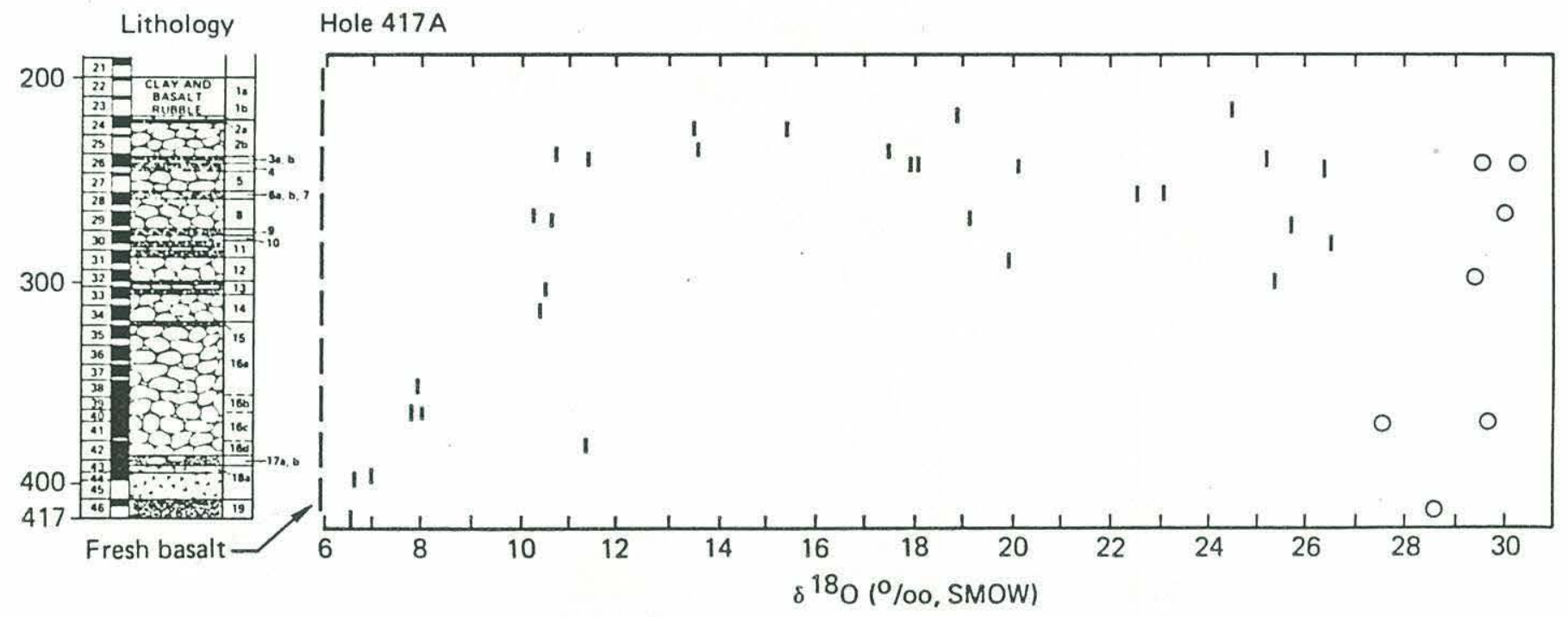

$\delta 180$ of basalts (bars) and carbonates (dots) from Hole $417 \mathrm{~A}$ as a function of depth and lithology. The dashed line at $5.8 \%$ represents the initial $\delta 180$ of unaltered basalt. Note that the most altered basalts are from breccia zones or unit boundaries. 
Figure 21. Downhole distribution of alteration minerals from Pertsev and Rusinov (1980).

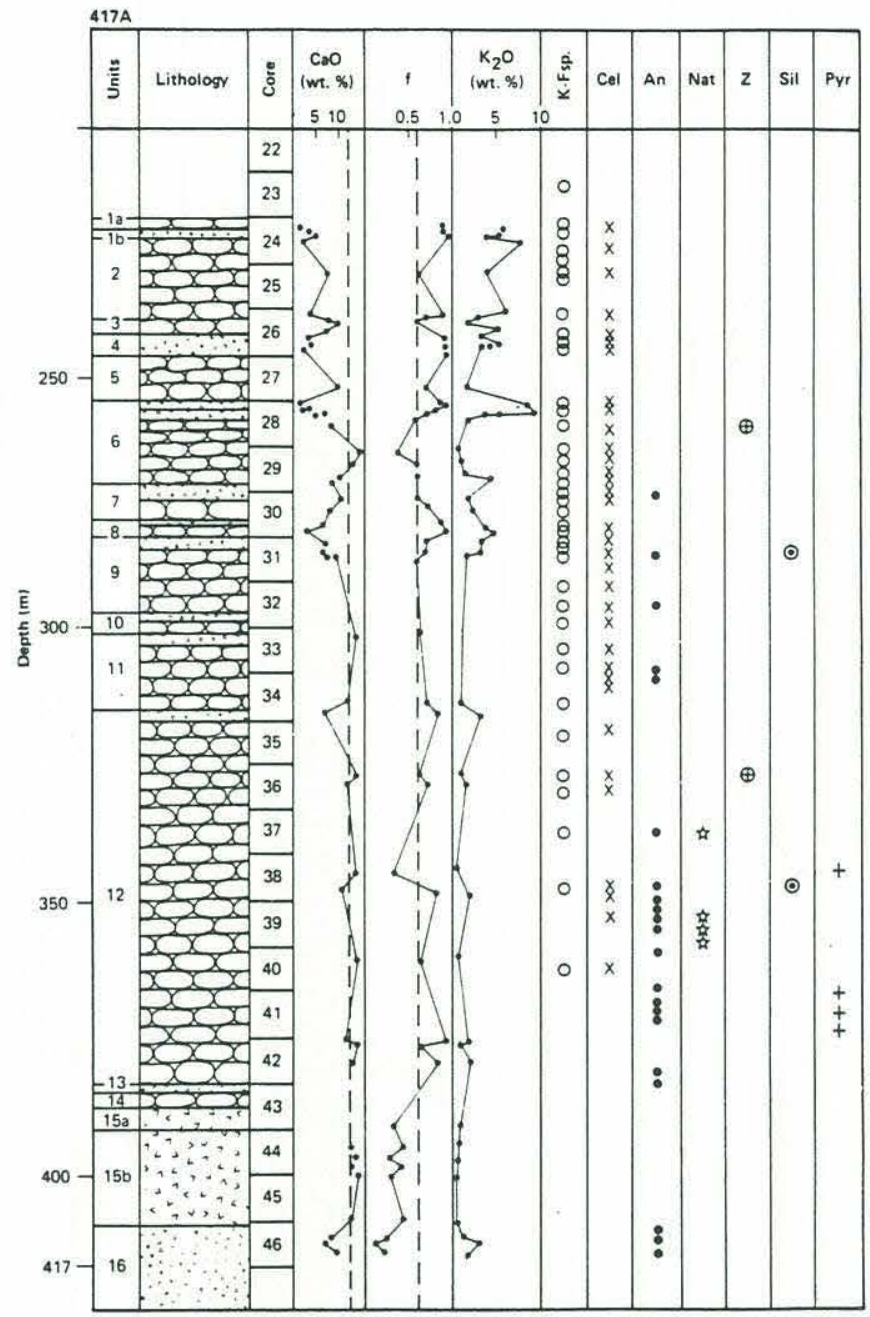

Distribution of some secondary minerals in the holes: (a) $417 \mathrm{~A}$, (b) $417 \mathrm{D}$, and (c) $418 \mathrm{~A} .1$ = pillow lava, 2 = breccia and hyaloclastite, $3=$ massive coarsegrained subophytic basalts; $f=\mathrm{Fe}_{2} \mathrm{O}_{3} /\left(\mathrm{Fe}_{2} \mathrm{O}_{3}+\mathrm{FeO}\right)$. $A n=$ analcime, $K$-Fsp $=K$-feldspar, Nat $=$ natrolite, $P h=$ phillipsite, Pyr $=$ pyrite, $\mathrm{Cel}=$ celadonite, $\mathrm{Ox}=$ ferrix oxides, $Z=$ zeolites, circles = analcime, square = apophyllite, $Q=$ quartz (triangles), $O l=$ fresh olivine, and Sil $=$ silica minerals.

$1=$ Pillow lavas

2 =Breccias

$\because \because 3=$ Holocrystalline basalts 
Figure 21 continued.
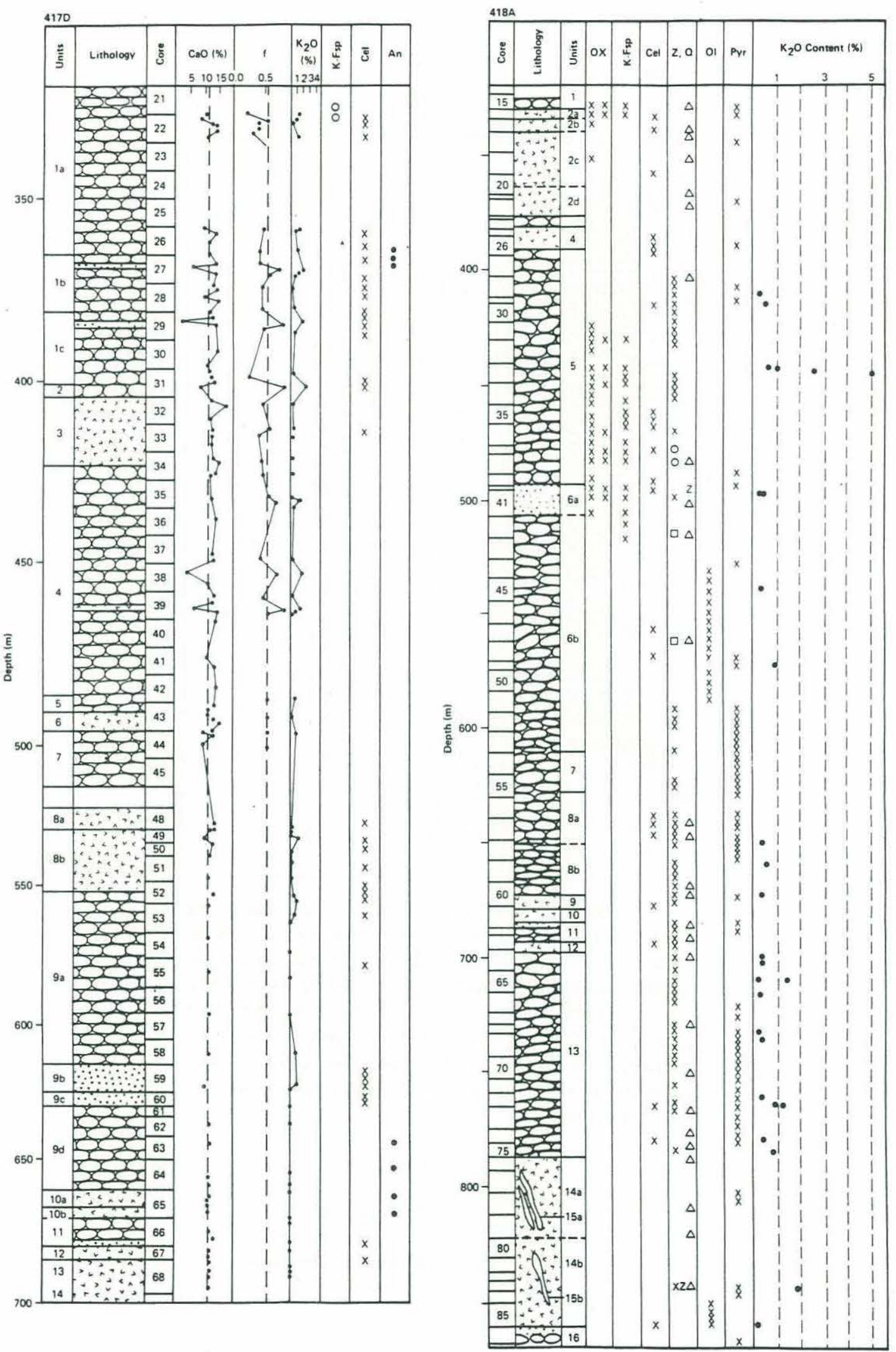
was altered to K-rich celadonite and/or nontronite by early low-temperature oxidative alteration. Plagioclase phenocrysts in pillow basalt with low porosity, high density, and high velocity altered to potassium feldspar by a later oxidative reaction.

The sequence of alteration differs between 417A and 417D/418A. In the latter, Pritchard (1980) and Gitlin (1985) find evidence for a brief, high temperature event, whereas other studies find none. At 417A, an early stage of leaching was followed by oxidising conditions, indicated by the presence of hematite and celadonite, during which cavities were filled with secondary minerals (Humphris, 1980). Carbonates were the last minerals to precipitate. At 417D and 418A, alteration of olivine and celadonite precipitation in vesicles and veins occurred first. With a change in fluid chemistry to reducing conditions, the next minerals deposited were pyrite, zeolites, saponite, and possible quartz. Extensive precipitation of carbonate and limonite occurred later. Mevel (1980) and Holmes (1988) describe slightly different sequences and present different, more detailed chronologies.

Isotopic analyses provide additional constraints on the temperature and extent of alteration. By isotopic dating (Hart and Staudigel, 1978; Richardson et al., 1980; Staudigel et al., 1981) and comparison to younger rocks (Alt and Honnorez, 1984), the silicate mineral vein-filling event occurred within a few million years of crustal formation. Calcite precipitation continued for up to $10 \mathrm{Ma}$.

Alteration changes the bulk chemistry of the rock. Selective leaching of unstable, high-temperature phases removes certain elements, while precipitation of low-temperature phases increases the concentration of other elements. Generalizations are difficult because, as described above, alteration conditions and products may vary vertically in a hole and laterally over a few hundred meters. Bulk rock analyses suggest that oxidative alteration of Hole 417A resulted in net gain of potassium, rubidium, cesium, phosphorus, lithium, boron and barium and net losses of calcium, magnesium, sodium, and manganese (slightly); concentrations of silicon, titanium, total iron, most rare earth elements, strontium 
and aluminum did not change (Donnelly et al., 1980b; Ui et al., 1980; Joron et al., 1980; Rice et al., 1980; Humphris et al., 1980; Staudigel et al., 1981). Alteration of 417D and $418 \mathrm{~A}$ rocks under reducing conditions produced geochemical exchanges with seawater which differ in magnitude and direction for some elements: potassium, magnesium, phosphorous, manganese and sodium show no fluxes in Hole 418A (Humphris et al., 1980; Donnelly et al., 1980a). Thompson (1983) recalculated elemental fluxes for 418A (his Table 47.14) and 417A (his Table 47.16). Chemical budget implications of the alteration of basaltic glass to palagonite are discussed by Juteau et al. (1980) and Staudigel and Hart (1983). ${ }^{18} \mathrm{O}$ is enriched in altered basalt increasing $\delta^{18} \mathrm{O}$ (Muehlenbachs, 1980; Javoy and Fouillac, 1980).

In summary, rocks from upper sections of Hole 417A are some of the most highly altered seafloor basalts recovered. Rocks from Holes 417D (450 m away) and 418A (7.5 km away) are among the freshest samples of old crust recovered (Honnorez, 1981). However, low-temperature alteration can be detected throughout 417D and 418A in the alkali composition of vitreous glass (Staudigel et al. 1980a), phenocryst phases, and ground mass minerals. Alteration occurs by a variety of geochemical processes active both synchronously and sequentially under changing geochemical conditions (e.g. Alt and Honnorez, 1984). Elements lost by one process may be precipitated during another, e.g., calcium. In Hole 417A some alteration indices clearly vary monotonically with depth, whereas in Holes 417D and 418A these same indices do not vary simply with depth (e.g. $\delta^{18} \mathrm{O}$, Muehlenbachs, 1980). Figures 19 and 20 show downhole profiles in 417A in two such indices, potassium and ${ }^{18} \mathrm{O}$ (Donnelly et al. 1980b; Muehlenbachs, 1980). In Holes 417D and 418A, alteration products are most common on pillow margins, between flow units, and in breccias. Although high-temperature hydrothermal processes may have briefly altered these rocks (Pritchard 1980), most alteration occurred when intra-formation water temperatures ranged from cold $\left(\sim 2-5^{\circ} \mathrm{C}\right)$ to warm $\left(40-50^{\circ} \mathrm{C}\right)$ (Muehlenbachs, 1980; Gitlin, 1985). 


\section{Paleomagnetism and Rock Magnetism}

Measurements on magnetic properties of basement rocks from Sites 417 and 418 are tabulated in Levi et al. (1980) and Hamano et al. (1980). Bleil and Smith (1980a) and Smith and Bleil (1980) discuss paleomagnetic and rock magnetic properties, respectively, of Holes 417A and 417D. Levi (1980) and Hamano et al. (1980) investigated paleomagnetism and rock magnetics of samples from 417D and 418A. Plasse (1980, 417A), Bleil and Smith (1980b, 417A and 417D), and Genkin et al. (1980, 417D and 418A) studied opaque mineralogy.

One of the most important observations made on Sites 417 and 418 samples is that the intensity of natural remanent magnetization in these holes (7-10 x 10-3 Gauss) is twice that measured in previous DSDP boreholes. These values are consistent with a $500 \mathrm{~m}$ thick magnetic source layer for marine magnetic anomalies (Bleil and Smith, 1980a; Levi, 1980).

The inclination of stable remanent magnetization varies significantly down hole in Holes 417D and 418A but not in 417A (Figures 22 and 23). Bleil and Smith (1980a) and Levi (1980) interpret these variations differently. Bleil and Smith (1980a) argue that the variations differ significantly from inclination predicted for the paleolatitude at the time of formation and ascribe the variation to block tilting of $<10^{\circ}$ in $417 \mathrm{~A}$ and at least $40^{\circ}$ in the upper $145 \mathrm{~m}$ of 417D. Kelts and Giovanoli (1980) and the Site 417 shipboard report section on structural features find that pillow thickness, dip of pillow margins, dip of intercalated limestone beds, and attitude of joints in massive basalts are consistent with tilting (Donnelly et al. 1980, Part 1). The shipboard scientists judged, however, that neither the quantity nor quality of these data were sufficient to confirm the hypothesis.

Levi (1980) argues that the mean inclinations in 417D and 418A do not differ significantly from the predicted inclination and ascribes the changes in inclination to secular variation. He finds no evidence for tilting. Moreover, Levi (1980) suggests that three distinct groupings of stable inclination in both $417 \mathrm{~A}$ and $418 \mathrm{~A}$ correspond to separate magma eruption events and that the total time for extrusive emplacement is at least several 
Figure 22. Downhole distribution of magnetic properties in Hole 417A from Bleil and Smith (1980a).

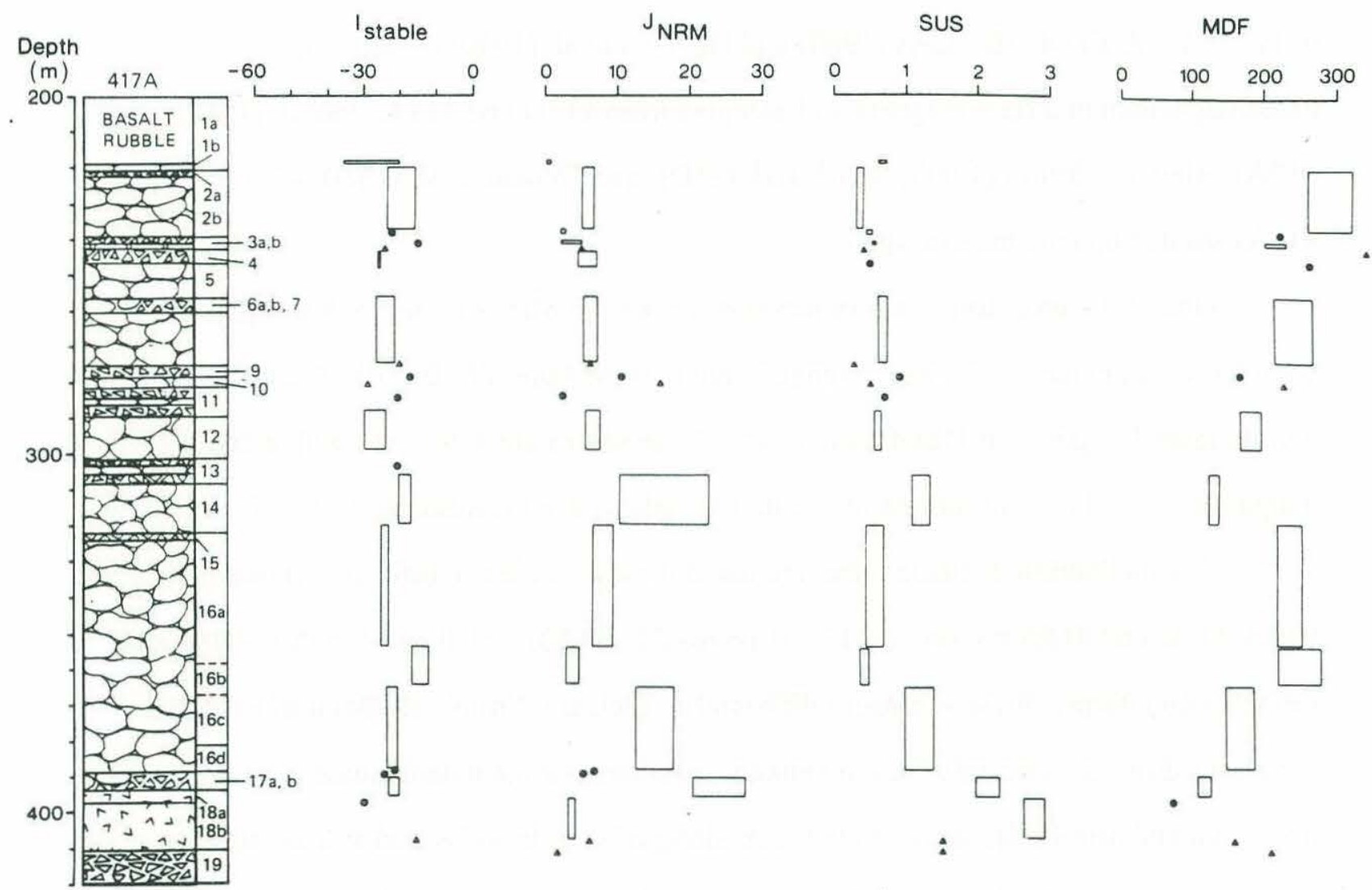

Magnetic units and individual samples for Hole 417A. The length and width of the bars indicate the thickness of each magnetic unit and the standard deviation of the mean, respectively (see Table 1). For individual samples, circles $=$ pillowed basalt; triangles $=$ breccia. . Downhole variation of stable inclination $\left(I_{\text {stable }}\right.$ in degrees $)$, intensity of natural remanent magnetization $\left(J_{N R M}\right.$ in emu/ $\left.\mathrm{cm}^{3} \times 10^{-3}\right)$, initial susceptibility (SUS in emu/cm ${ }^{3}$. Oe $X\left(0^{-3}\right)$, and median destructive field (MDF in Oe). 
Figure 22 (continued). Hole 417D from Bleil and Smith (1980a).

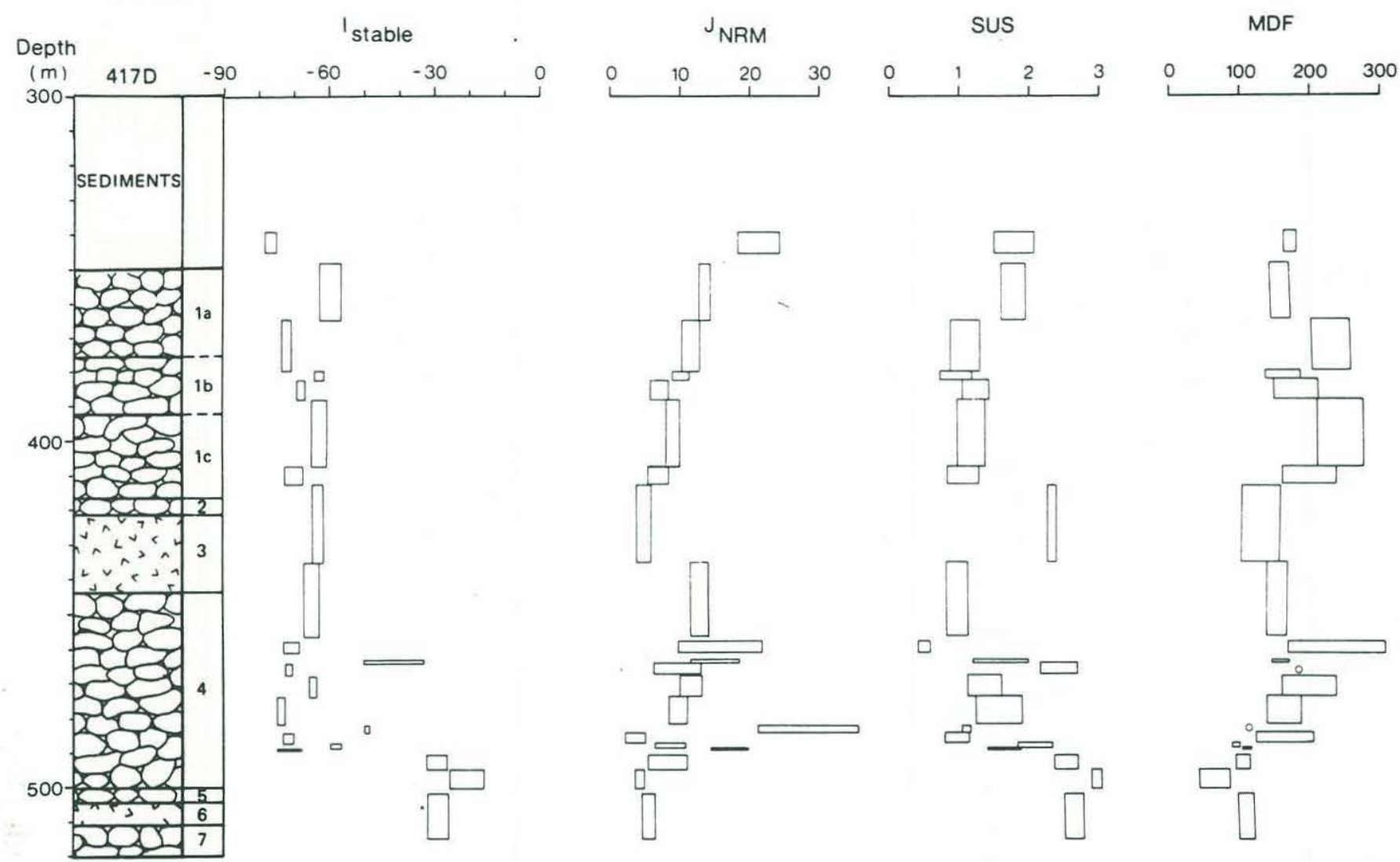

Magnetic units and individual samples for Hole 417D. The length and width of the bars indicate the thickness of each magnetic unit and the standard deviation of the mean, respectively (see Table 2). For individual samples, circles =

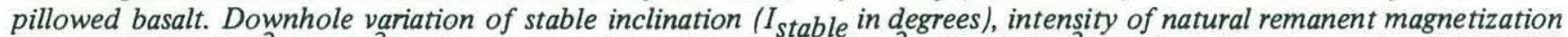
$\left(J_{N R M}\right.$ in emu/cm $\mathrm{cm}^{3} \times 10^{-3}$ ), initial susceptibility (SUS in emu/cm $\mathrm{cm}^{3} \cdot$ Oe $\left.\times 10^{-3}\right)$, and median destructive field (MDF in $\mathrm{Oe})$. 
Figure 23. Downhole distribution of magnetic properties in Hole 417D from Levi (1980).

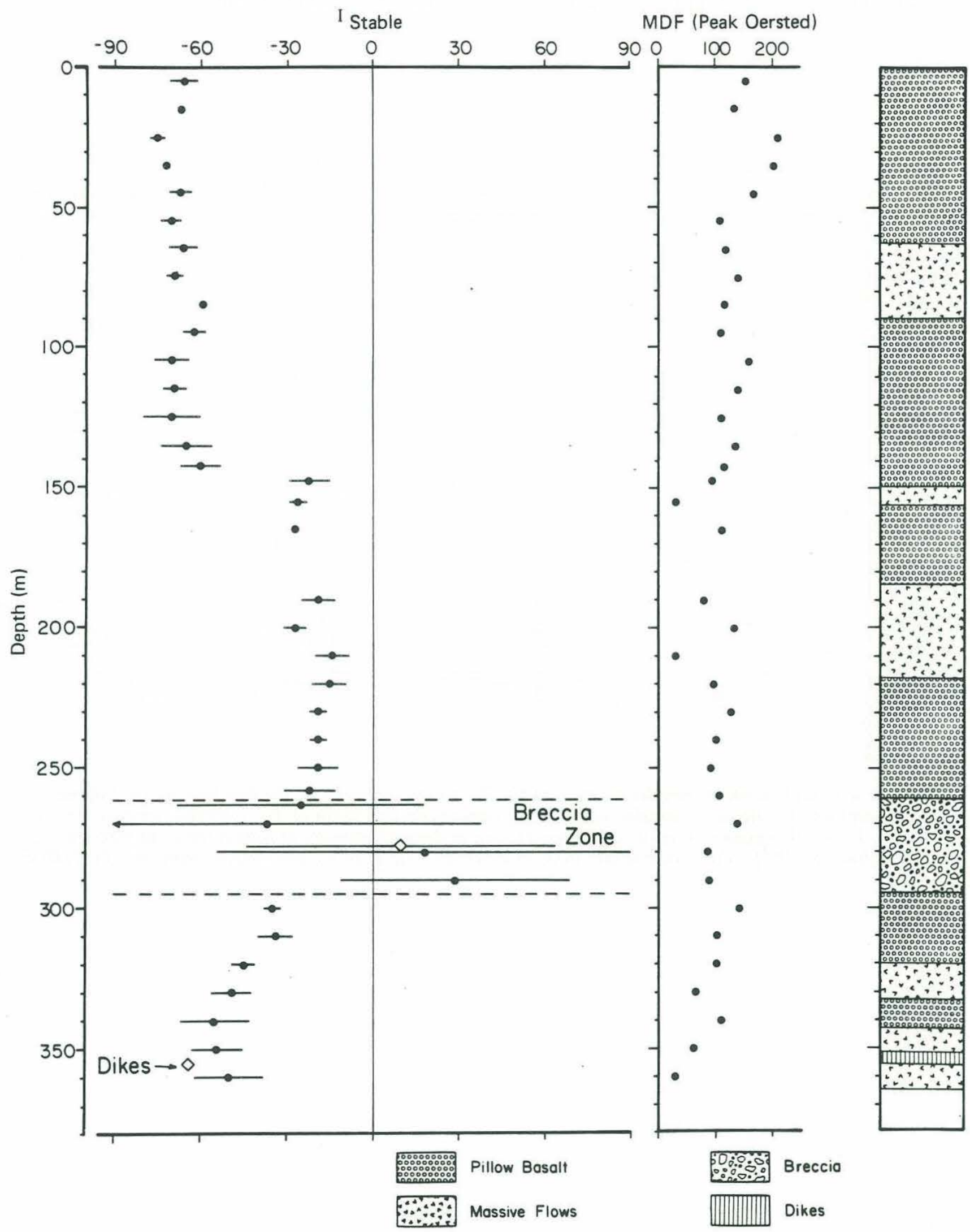

Downhole variations of I ITABLE and MDF for Hole 417D. Data represent 10-meter averages; depth is measured from the top of the igneous section; bars surrounding data represent one standard deviation. 
Figure 23 continued. Hole 418A. 65

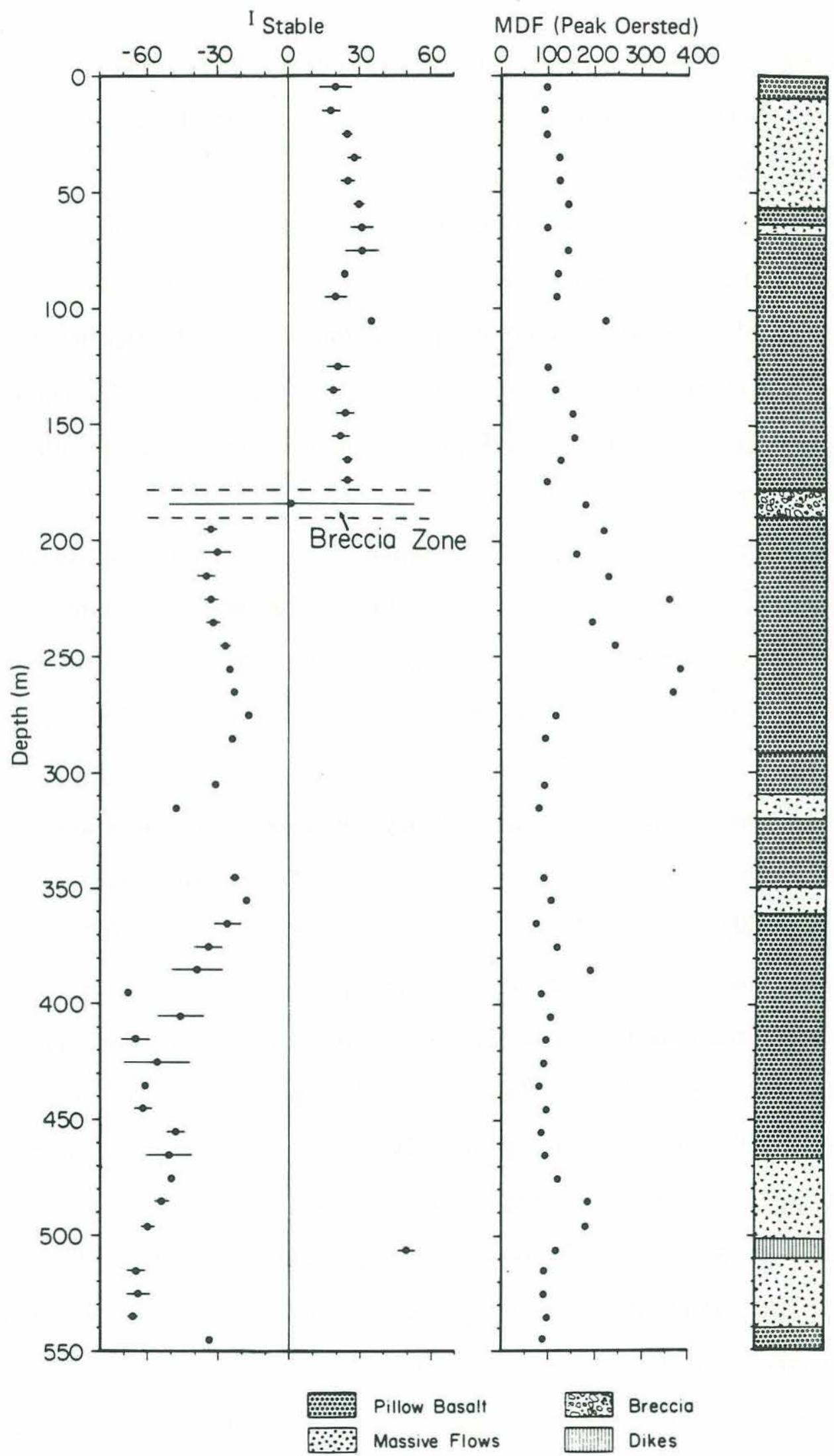

Figure 3.

Downhole variation of ISTABLE and MDF for Hole 418A. All else is as in 
thousand years. Levi (1980) places these boundaries at $145 \mathrm{~m}$ and 260-295 m (breccia zone) in 417D and at $178-190 \mathrm{~m}$ (breccia zone) and $390 \mathrm{~m}$ depth in $418 \mathrm{~A}$.

\section{$\underline{\text { Physical Properties }}$}

The site reports contain results of shipboard measurements of wet bulk density, compressional wave velocity perpendicular to core axis, and porosity (Donnelly et al., 1980; Figure 24). From these measurements, grain density and acoustic impedance were calculated. Using average property values for common lithologies and the distribution of lithologies with depth, Donnelly et al. (1980) reconstructed continuous depth profiles of density, velocity and porosity (Figure 24).

In $417 \mathrm{~A}$, properties clearly varied with depth. Density increased downward from 2.4 to $2.85 \mathrm{gm} / \mathrm{cm}^{3}$ at the base of hole. Velocity also increased downward from 3.8 to greater than $5.8 \mathrm{~km} / \mathrm{s}$. Porosity decreased from greater than $25 \%$ to $7.8 \%$. Breccias gave

extreme values for density, velocity, and porosity of $2.2-2.5 \mathrm{gm} / \mathrm{cm}^{3}, 2.9 \mathrm{~km} / \mathrm{s}$, and up to $56 \%$, respectively.

At 417D, physical properties show little dependence on depth (Figure 24). Throughout, values are similar to those at the base of Hole 417A. Density averages $2.8 \mathrm{gm} / \mathrm{cm}^{3}$, velocity averages $5.5 \mathrm{~km} / \mathrm{s}$, and porosity ranges between 2 to $10 \%$.

At Hole 418A, physical properties vary with depth in a manner similar to Hole $417 \mathrm{~A}$, but density and velocity are higher, porosity is lower, and the variations are less. Density ranges from 2.3 to $3.0 \mathrm{gm} / \mathrm{cm}^{3}$ and averages 2.8 . Velocity averages $5.6 \mathrm{~km} / \mathrm{s}$ but ranges from $2.8-4.85 \mathrm{~km} / \mathrm{s}$ in breccias to $5.75-6.24 \mathrm{~km} / \mathrm{s}$ in massive basalts. Porosity decreases with depth below $~ 75$ m subbasement from $5-10 \%$ to $1-2 \%$ at bottom. Seawater permeability ranges from $2.0 \times 10^{-16} \mathrm{~cm}^{2}$ in coarsely grained basalt to $1.4 \times 10^{-13} \mathrm{~cm}^{2}$ in breccia. Donnelly et al. (1980) infer that large depth scale changes are due to changes in degree of alteration rather than to lithologic variations.

Hamano (1980) made additional density, velocity, and porosity measurements on Hole 417D and 418A samples. He also measured electrical resistivity (20 to $1714 \mathrm{ohm}-\mathrm{m}$, 
Figure 24. Basement physical properties from Donnelly et al. (1980).

(a) Hole $417 \mathrm{~A}$.
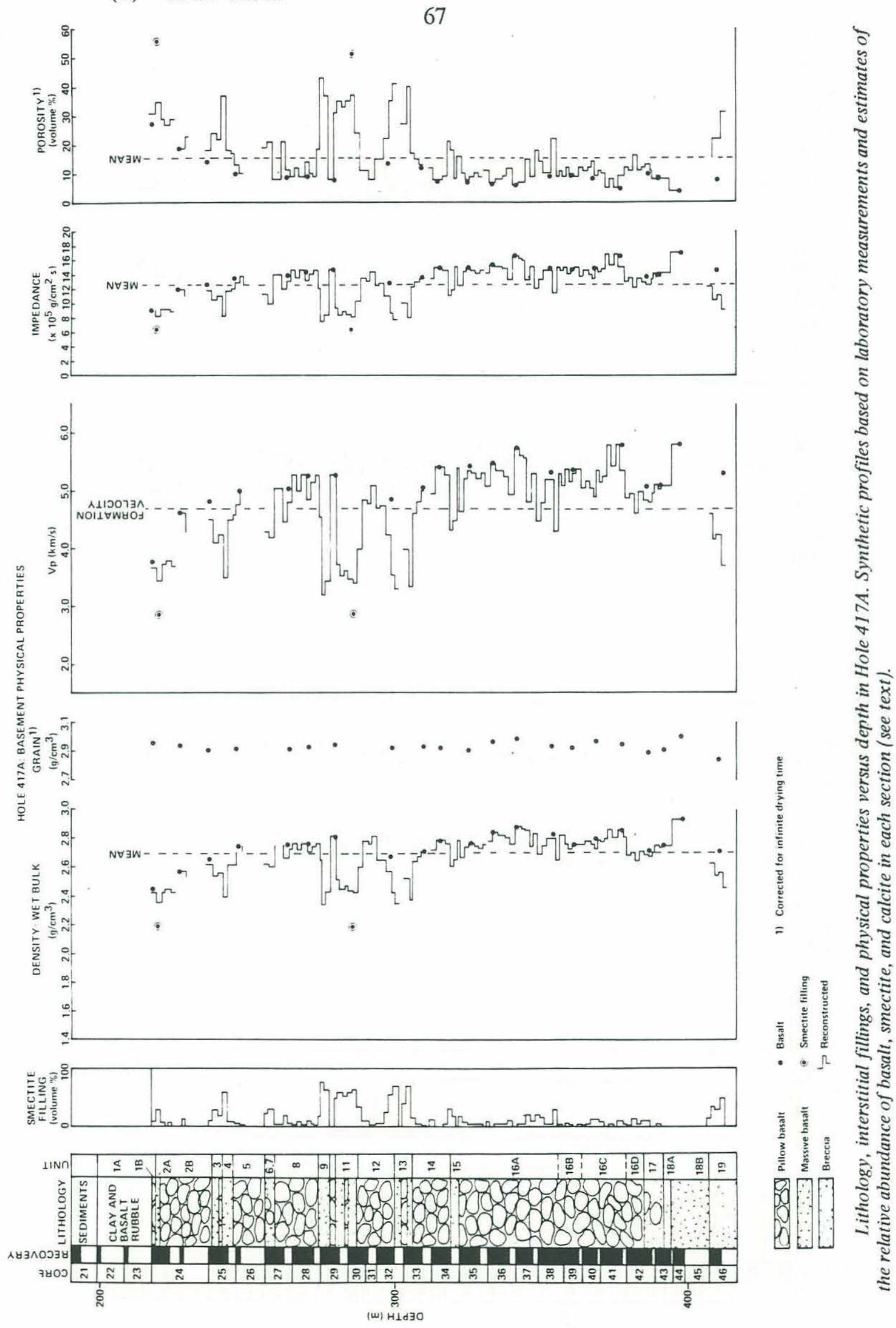
Figure 24. (b) Hole 417D from Donnelly et al (1980).
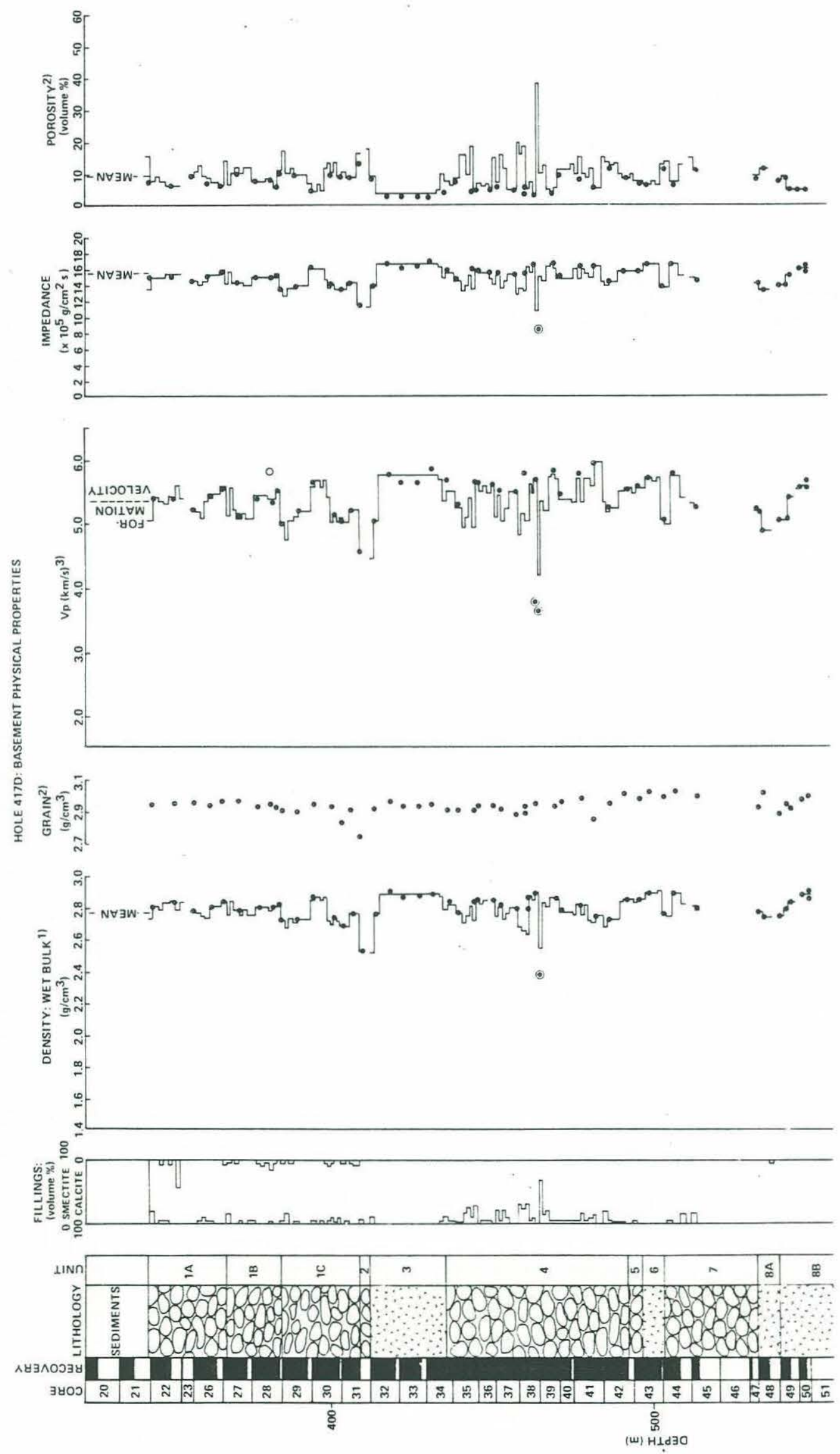
Figure 24. (b) continued
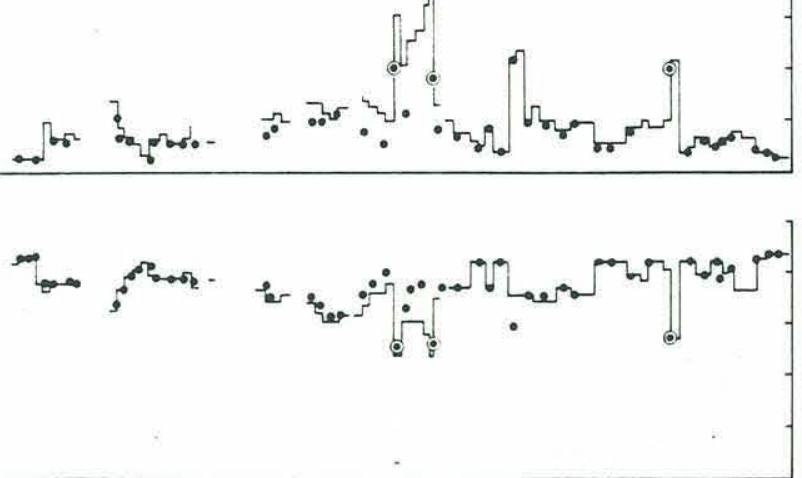

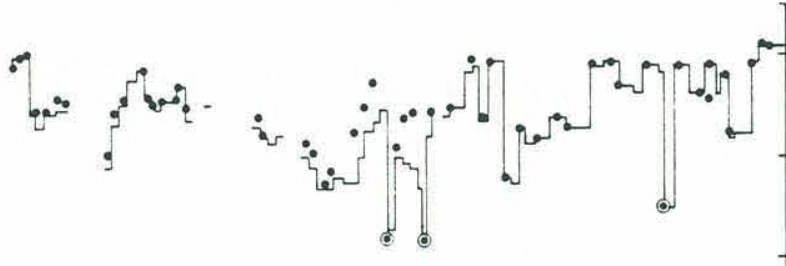

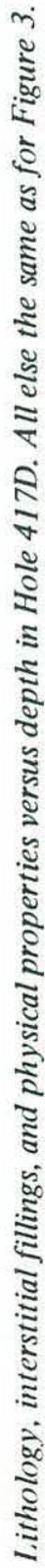

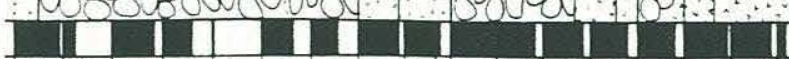


Figure 24. (c) Hole 418A from Donnelly (1980).
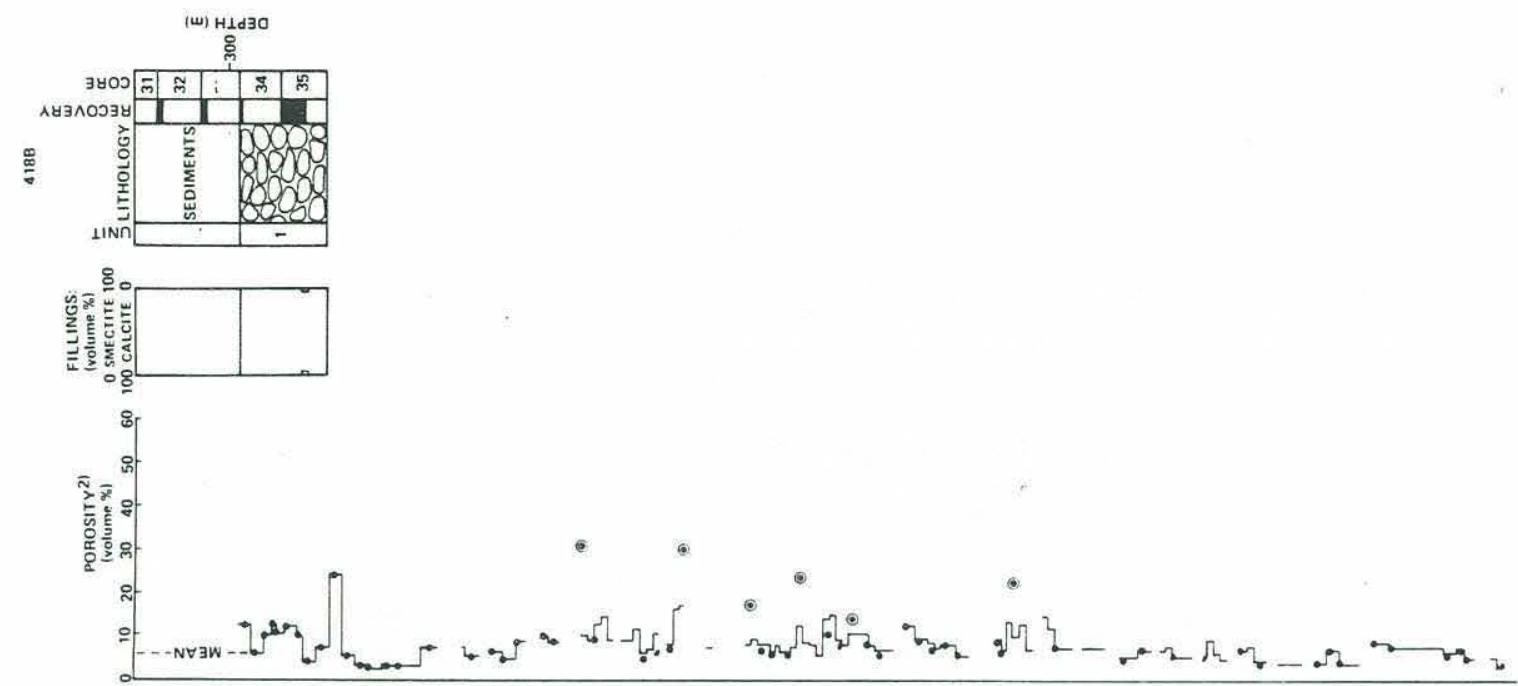

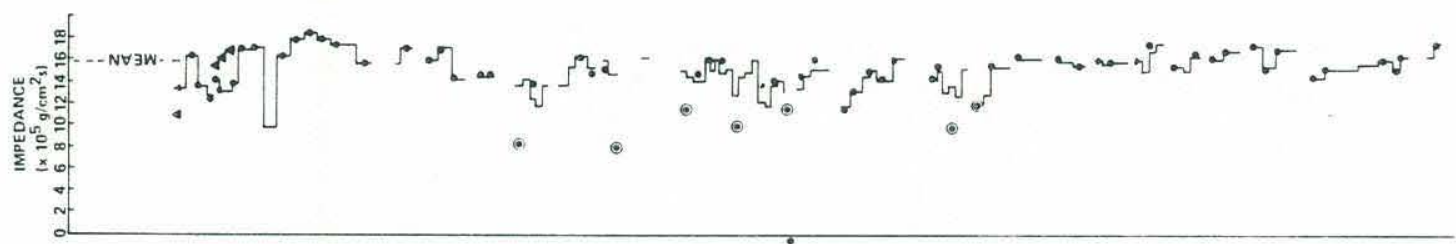

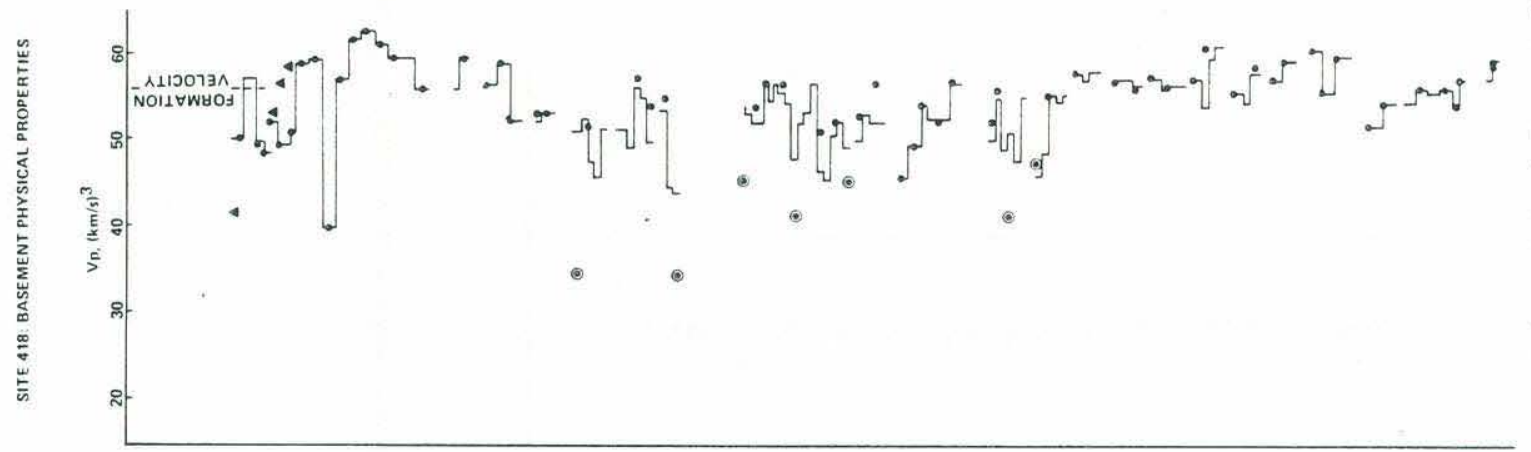

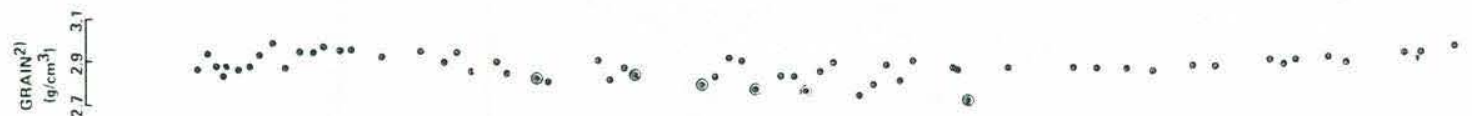

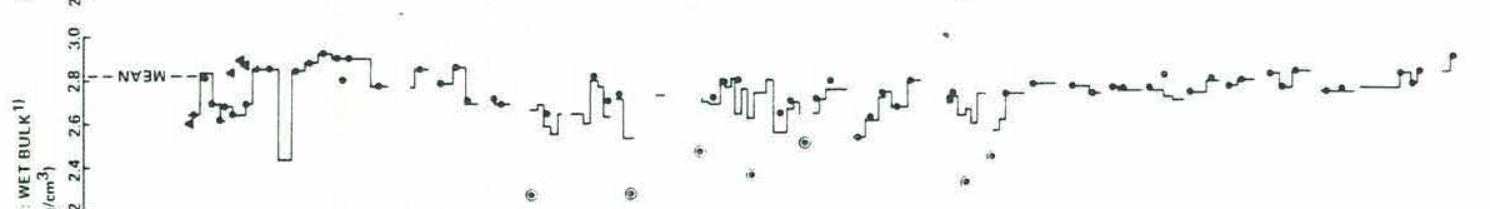

帘

. 
Figure 24. (c) continued

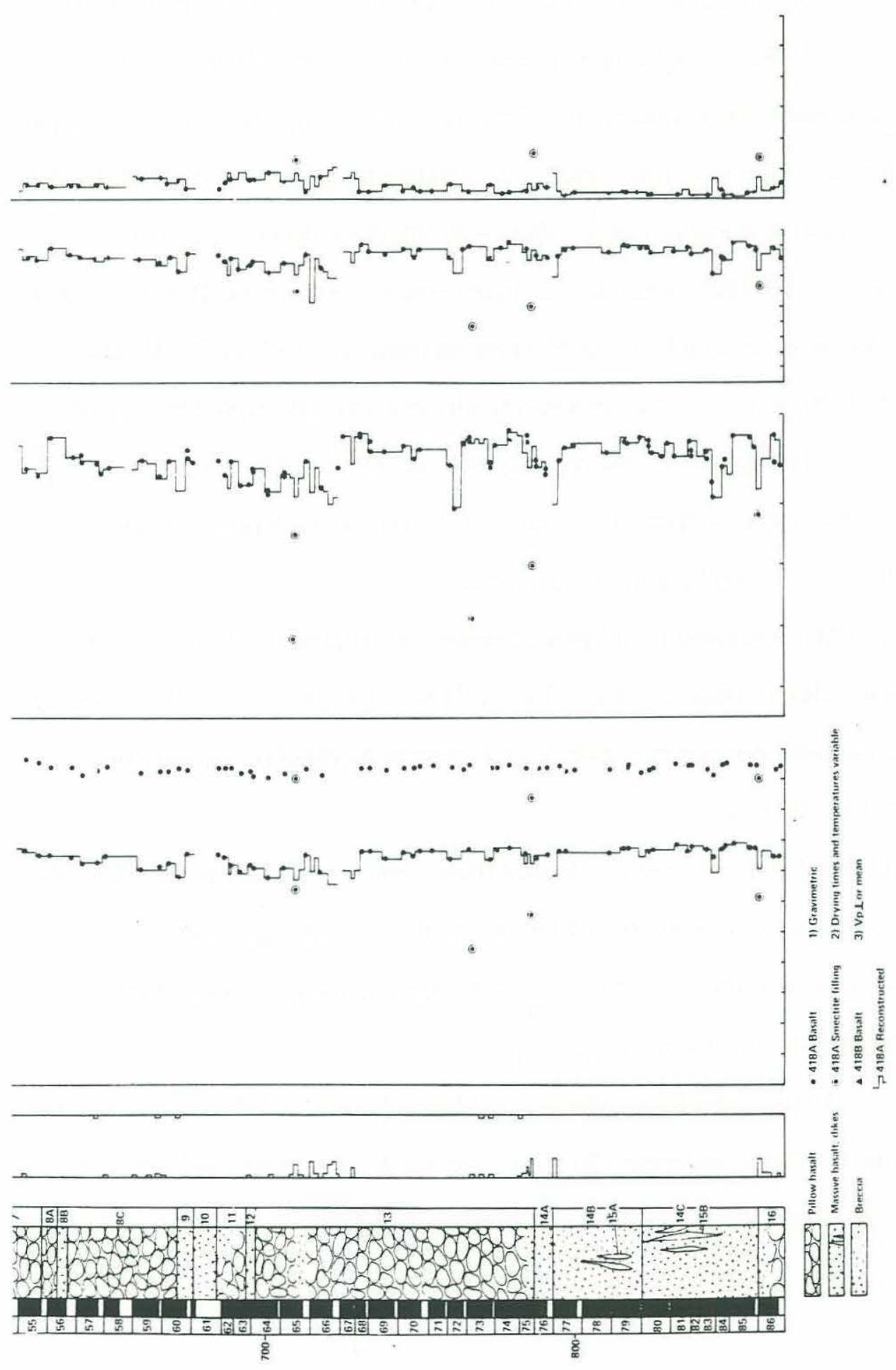


mean $=120)$, thermal conductivity $\left(4.03\right.$ to $4.64 \mathrm{~m} \mathrm{cal} / \mathrm{cm}-\mathrm{sec}-{ }^{\circ} \mathrm{C}$, mean $\left.=4.31\right)$, shear velocity $(2.59$ to $3.4 \mathrm{~km} / \mathrm{s}$, mean $=3.10)$, and air permeability $\left(2.7 \times 10^{-17}\right.$ to $2.8 \times 10^{-}$ ${ }^{14} \mathrm{~cm}^{2}$, mean $=1.1 \times 10^{-16}$ ). He calculated a mean Poisson's ratio of $0.282 \pm 0.011$. Hamano (1980) also measured P-velocity as a function of confining pressure up to $1 \mathrm{Kbar}$ and found that the correction to in situ conditions ( 300 bars) is $\sim 3.5 \%$ and is independent of initial velocity. Most physical properties show a strong dependence on porosity.

Christensen et al. (1980) measured wet-bulk density, porosity and P-wave velocity under confining pressures up to $6 \mathrm{Kbar}$ for 88 samples from Holes 417A, 417D, and 418A. Most data fell closely about the density-velocity relationship derived by Christensen and Salisbury (1975). Unexpectedly, the porosity-velocity relationship did not vary at different confining pressures. Apparently, even these extremely high pressures are insufficient to close vesicles and grain-boundary cracks.

Johnson (1980b) measured liquid permeabilities on 10 samples from Hole 418A. The average permeability of fresh basalt is $5.2 \times 10^{-16} \mathrm{~cm}^{2}$. The presence of smectite clays tends to decrease permeability, whereas calcite veins tend to increase it. He measured a total range of $10^{-14}$ to $10^{-17} \mathrm{~cm}^{2}$.

Johnson (1980a) counted open cracks and filled veins throughout Hole 418A. Not surprisingly, peak counts corresponded with depths of lithology change and breccias. Oblique cracks were more common than vertical or horizontal cracks. Zones of intense cracking may significantly affect seismic velocity.

Choukroune (1980) studied microfracture evidence for brittle deformation of basalt samples from Hole 417D and the lower $150 \mathrm{~m}$ of Hole 418A. Only tensional structures with dips of $50^{\circ}-60^{\circ}$ occur in Hole 417D. Low angle reverse faults were observed in $418 \mathrm{~A}$ samples. 


\section{LOGGING STUDIES}

\section{Hole 417D - DSDP Leg 51}

Hole 417D was logged on Leg 51 after $\sim 128 \mathrm{~m}$ of basement penetration. Twentyfive meters of 16 inch steel casing, hung from the re-entry cone, protected the top of the hole. Logging operations took over five days. During logging, the bottom of the drill pipe was usually at $\sim 190 \mathrm{~m}$ below seafloor, so the only sediment logged in open-hole conditions was the basal, Cretaceous section ( 150m thick). Difficulties included frequent sediment bridges, in-filling of basement section, and failure of tools and rigging. Only three of nine tools run gave "excellent results". Logging reached $\sim 100 \mathrm{~m}$ subbasement depth. Figure 25 and Table 10 show tool coverage.

Salisbury et al. (1980a) describe the corrected logging results, which are provided on a fold-out sheet ( 22 inches long) accompanying the site report volume. In the sediment section, no significant results were obtained, although several deeper unit boundaries were better positioned using logs. Figure 26 shows the results of basement logging. In both sediments and basement, changes in velocity, density, porosity, and resistivity appear to coincide with lithology changes. Basement sonic velocities range between 4.7 and 5.8 $\mathrm{km} / \mathrm{s}$ and average $5.3 \mathrm{~km} / \mathrm{s}$. Because sonic log velocities for massive basalts agree with laboratory measurements, Salisbury et al. (1980a) concluded that log velocities are accurate. The uppermost $100 \mathrm{~m}$ of 417D has a formation velocity of $4.8 \mathrm{~km} / \mathrm{s}$ consistent with results from the oblique seismic experiment (see below) and with seismic refraction data for old, slow-spreading crust. Significant porosity remains despite precipitation of low-temperature alteration minerals. The porosity of pillow basalts averages $13 \%$ and is distributed $8 \%$ due to grain boundary porosity and $5 \%$ due to cracks filled with seawater. Porosity ranges from $20 \%$ in breccias to $3 \%$ in massive basalts (Salisbury et al., 1980b).

Resistivity values range from 3 (breccias) to $200 \mathrm{ohm}-\mathrm{m}$ (massive basalts) but generally fall between $30-80 \mathrm{ohm}-\mathrm{m}$. Since most values are less than typical laboratory 
Figure 25. Depth coverage of logging operations in Hole 417D on Leg 51. From Donnelly et a1. (1980).
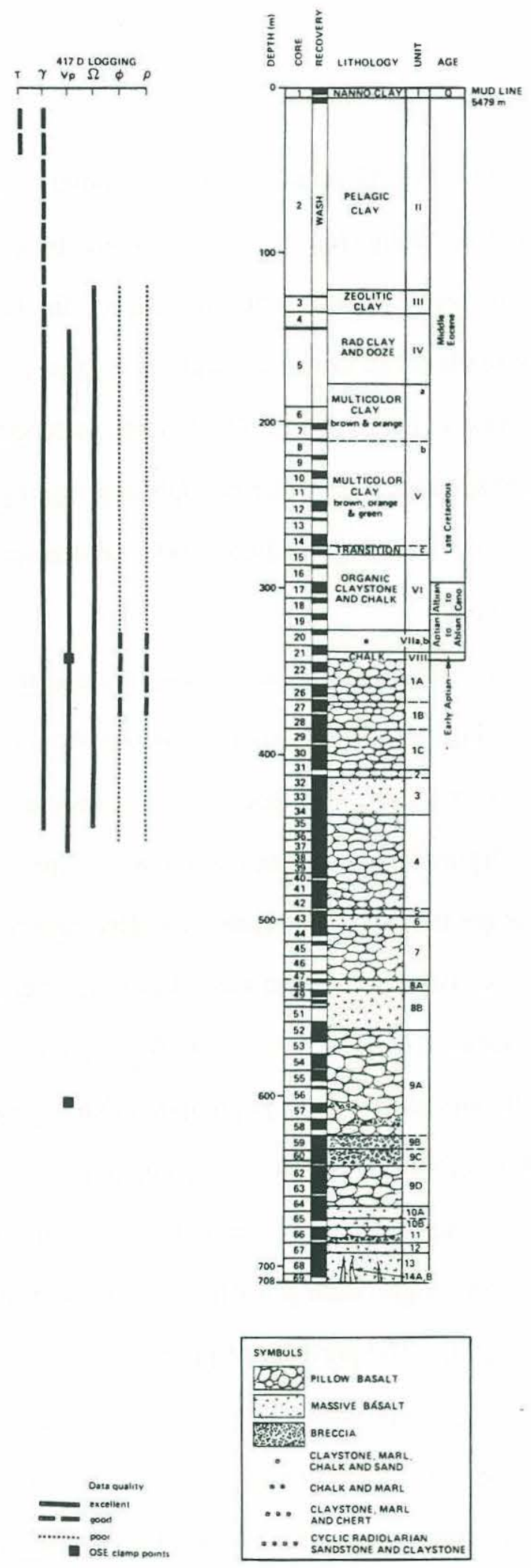

Logging intervals and data quality versus depth and lithology in Hole 417D. 
Table 10. From Salisbury et al. (1980a)

Hole 417D Geophysical Logging Runs

\begin{tabular}{|c|c|c|c|}
\hline Run & Tools & $\begin{array}{l}\text { Depth Interval } \\
\text { (m sub-bottom) }\end{array}$ & Remarks \\
\hline 1 & High Resolution Temperature (HRT) & $\begin{array}{r}0-44 \\
44-46\end{array}$ & $\begin{array}{l}\text { Through pipe } \\
\text { Open hole; terminated by caving }\end{array}$ \\
\hline 2 & $\begin{array}{l}\text { Borehole Compensated Velocity (BHC) } \\
\text { Natural Gamma Ray }\end{array}$ & $\begin{array}{r}144-445 \\
0-144 \\
144-445\end{array}$ & $\begin{array}{l}\text { Open hole } \\
\text { Through pipe } \\
\text { Open hole }\end{array}$ \\
\hline & Caliper & - & Signal lead broken, spot readings only \\
\hline 3 & $\begin{array}{l}\text { Gamma Ray Density } \\
\text { Neutron Porosity } \\
\text { Natural Gamma Ray }\end{array}$ & $\begin{array}{l}320-369 \\
114-443 \\
320-369 \\
114-443 \\
114-443\end{array}$ & $\begin{array}{l}\text { Open hole } \\
\text { Open hole; excentralizer broken; data not shown } \\
\text { Open hole } \\
\text { Open hole; excentralizer broken } \\
\text { Open hole }\end{array}$ \\
\hline 4 & $\begin{array}{l}\text { Electrical Resistivity } \\
\text { (ILM, ILD, LL8) } \\
\text { Natural Gamma Ray }\end{array}$ & $\begin{array}{l}117-434 \\
117-434\end{array}$ & $\begin{array}{l}\text { Open hole; no centralizer } \\
\text { Open hole }\end{array}$ \\
\hline
\end{tabular}


Figure 26. Corrected logs for basement section in Hole 417D.

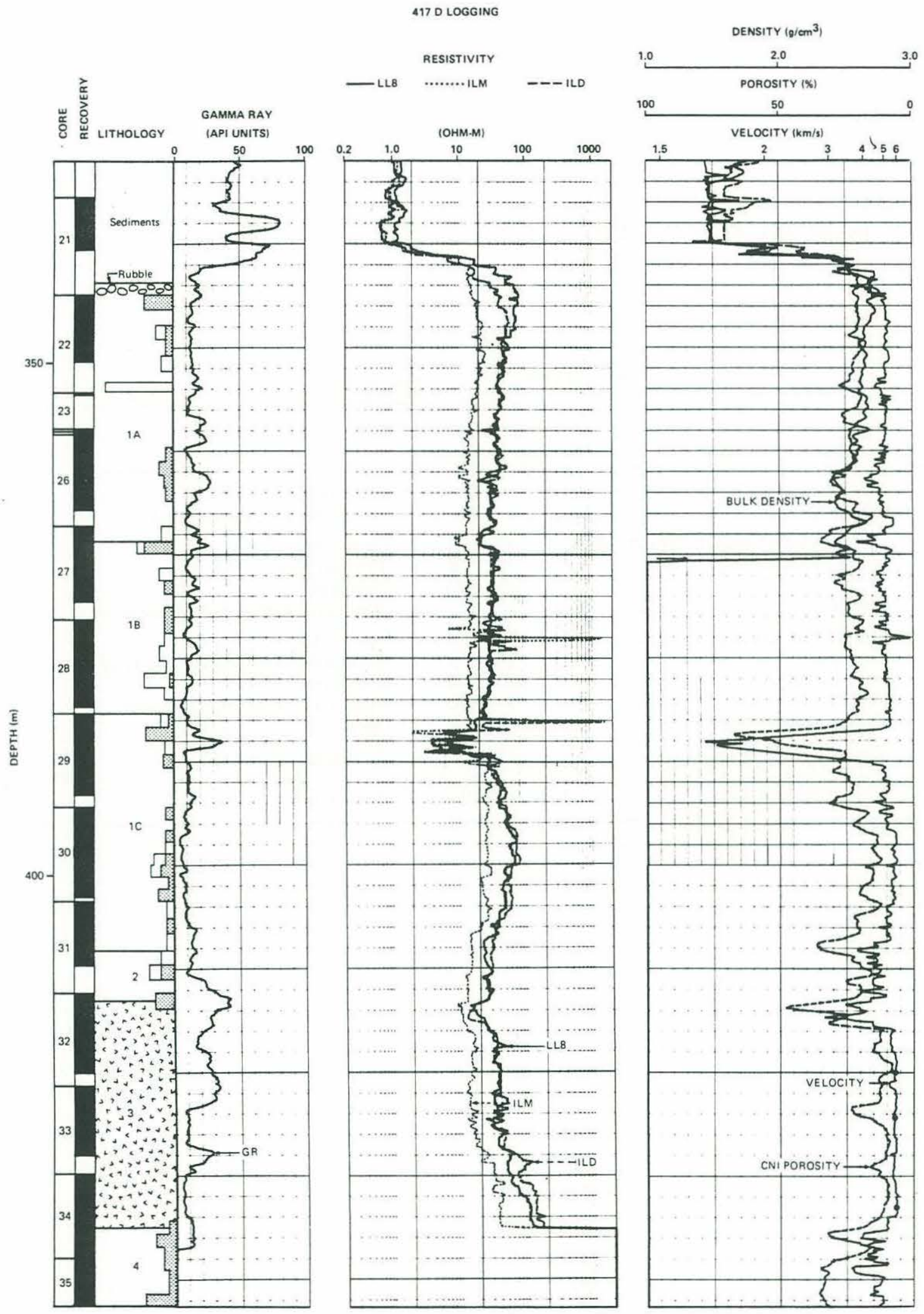

Basement logging data and lithology versus depth in Hole 417D. Units 1, 2, and 4 are composed of pillow basalt, while Unit 3 (hachured) is composed of massive basalt; insets in lithology column represent abundance of limestone (plain) and smectite (light gray) on a scale of 0 per cent to 50 per cent; circles $\left(\%\right.$ ) on velocity curve in Unit 3 represent laboratory velocities $\left(V_{p}\right)$ at an effective confining pressure of $0.1 \mathrm{kbar}$. 
Figure 27. Downhole coverage of logging operations in Hole 418A of Leg 102 from Shipboard Scientific Party (1986).
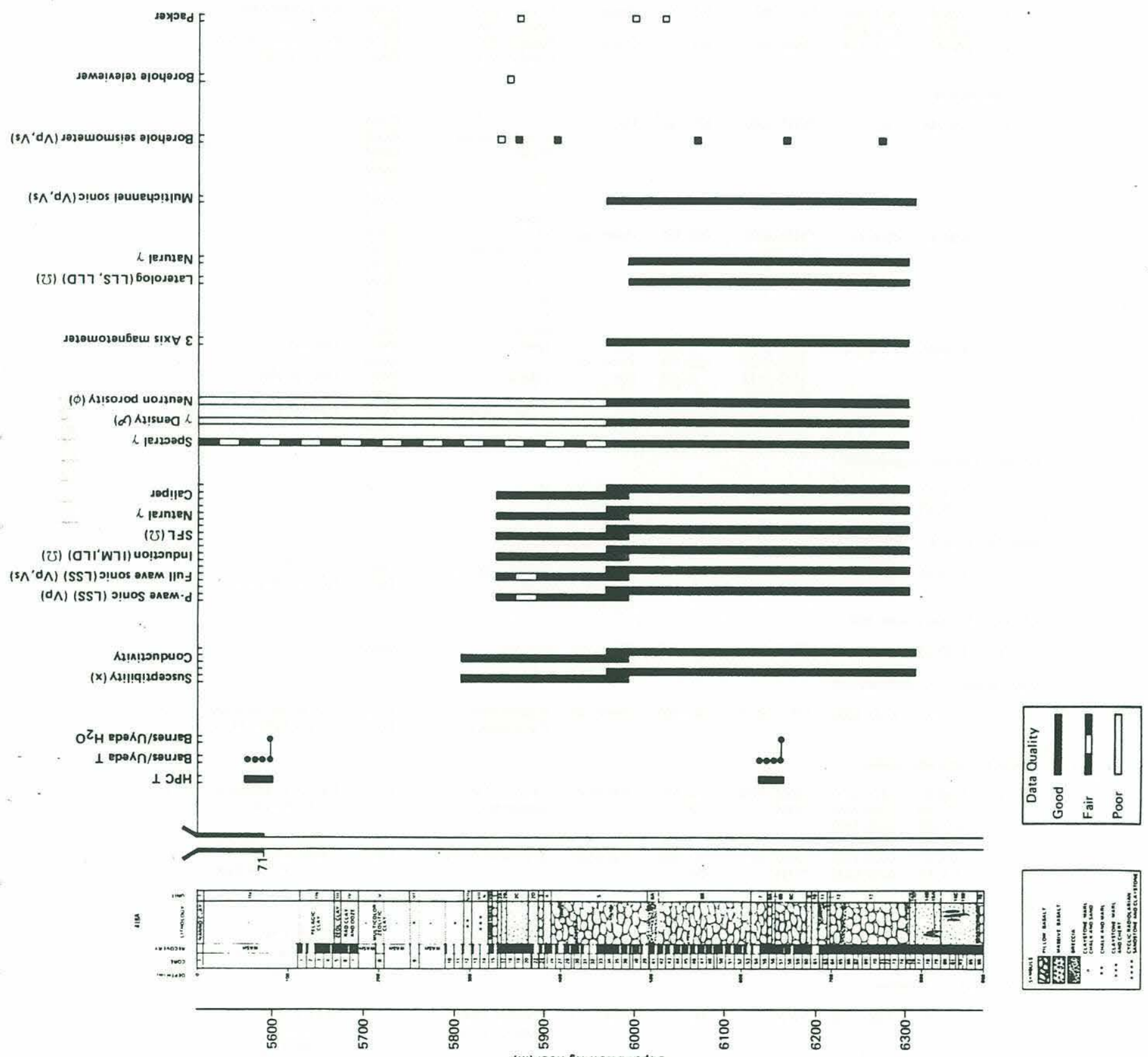

(w) $100156 ! 1$ moleq 42doO 
Table 11. From Shipboard Scientific Party (1986)

Leg 102 downhole-operations summary, Hole 418A.

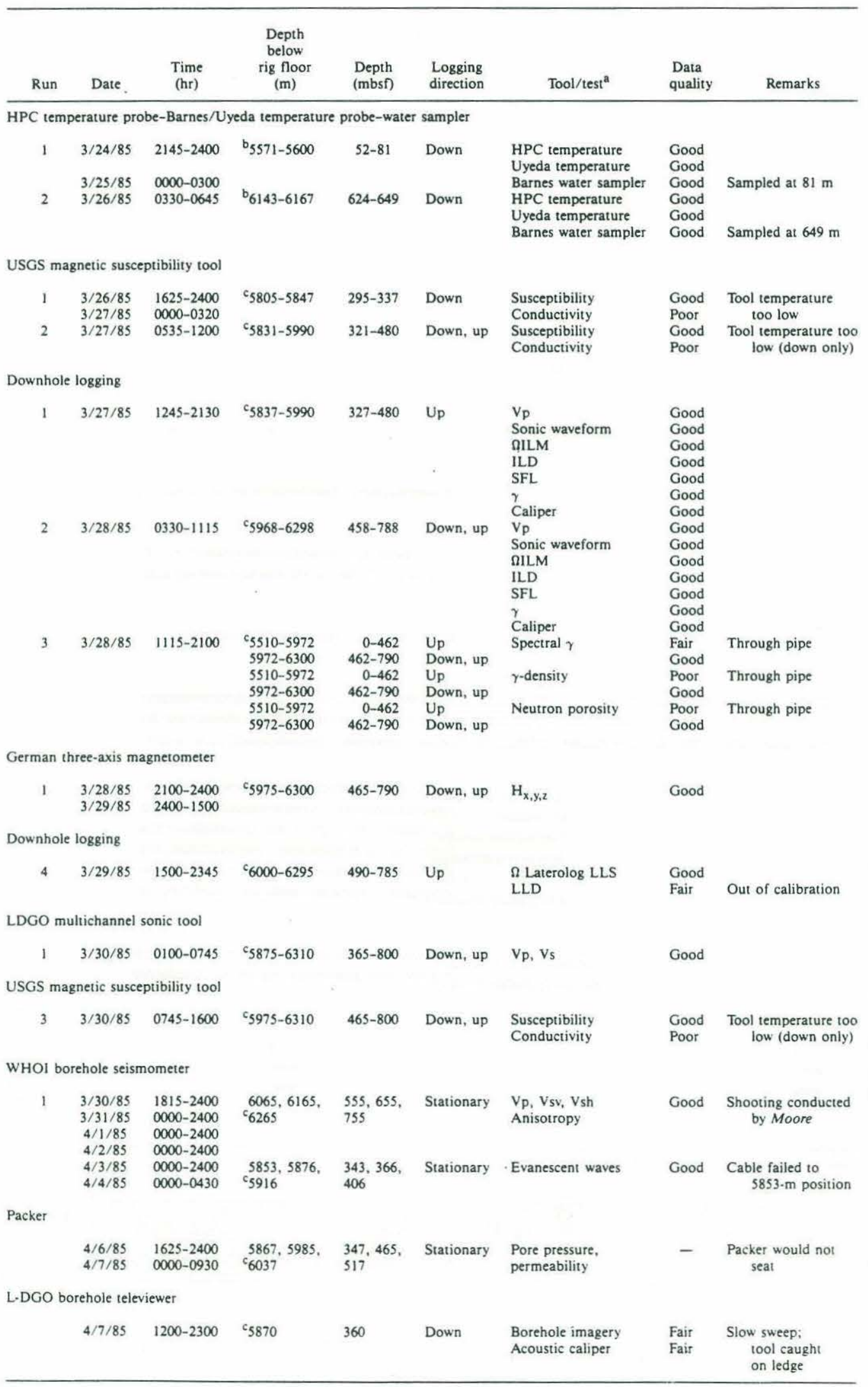

See text and Table 6 for specifications.

${ }^{b}$ Subtract $10 \mathrm{~m}$ to obtain depth below sea level.

'Equals depth below sea level (rig-floor height and cable stretch cancel each other, by coincidence). 
resistivities (97. ohm-m), Salisbury et al. (1980a) conclude that seawater-filled cracks penetrate basement.

\section{Hole 418A - ODP Leg 102}

ODP Leg 102 returned to Hole 418A to log the basement section. The site report (Shipboard Scientific Party, 1986) describes operations and initial results. Fifteen logging tools were run. Operations also included borehole water sampling and temperature measurements, an oblique seismic experiment, and unsuccessful attempts to operate a borehole packer and televiewer. Figure 27 and Table 11 show the depth distribution and overall quality of logging data. Since the pipe bottom was left near the sediment-basement contact during wireline logging, only the natural spectral gamma ray tool obtained reasonable data in the sediment section. Because a sonic tool and cable lost on Leg 53 were believed to be still in hole, logging stopped $\sim 100 \mathrm{~m}$ above total $\mathrm{m}$ hole depth $(450 \mathrm{~m}$ into basement). During hole washing operations done after logging was completed, no evidence of the tool was found.

Paper copies of the logs are provided with the Leg 102 site report. Figure 28 shows the composite depth section. Digital copies of the Schlumberger data are available from the Borehole Research Group at Lamont-Doherty Geological Observatory.

Carlson et al. (1988b) used the gamma ray log to revise unit boundaries in the sediment section (Figure 29). They used an empirical travel time-depth relation for deepsea sediments to correlate unit boundaries to seismic reflection events (Figure 30).

Broglia and Moos (1988) used Schlumberger logs (Figure 31) to determine in-situ physical properties (velocity, density, resistivity, and porosity) and to compute relative volume proportions of smectite, basalt, matrix porosity; and fracture porosity (Figure 32). They computed upper and lower bounds to original porosity and velocity (Figure 33). They subdivide the basement section into a relatively unaltered zone above $64 \mathrm{~m}(388 \mathrm{~m}$ below seafloor); a high-porosity, smectite-rich zone above $190 \mathrm{~m}$ (the breccia unit $6 \mathrm{a}$ at 514 $\mathrm{m}$ below seafloor); and low porosity zone below. 
Figure 28. Basment logs collected in Hole 418A on ODP Leg 102 from Salisbury et al (1988).

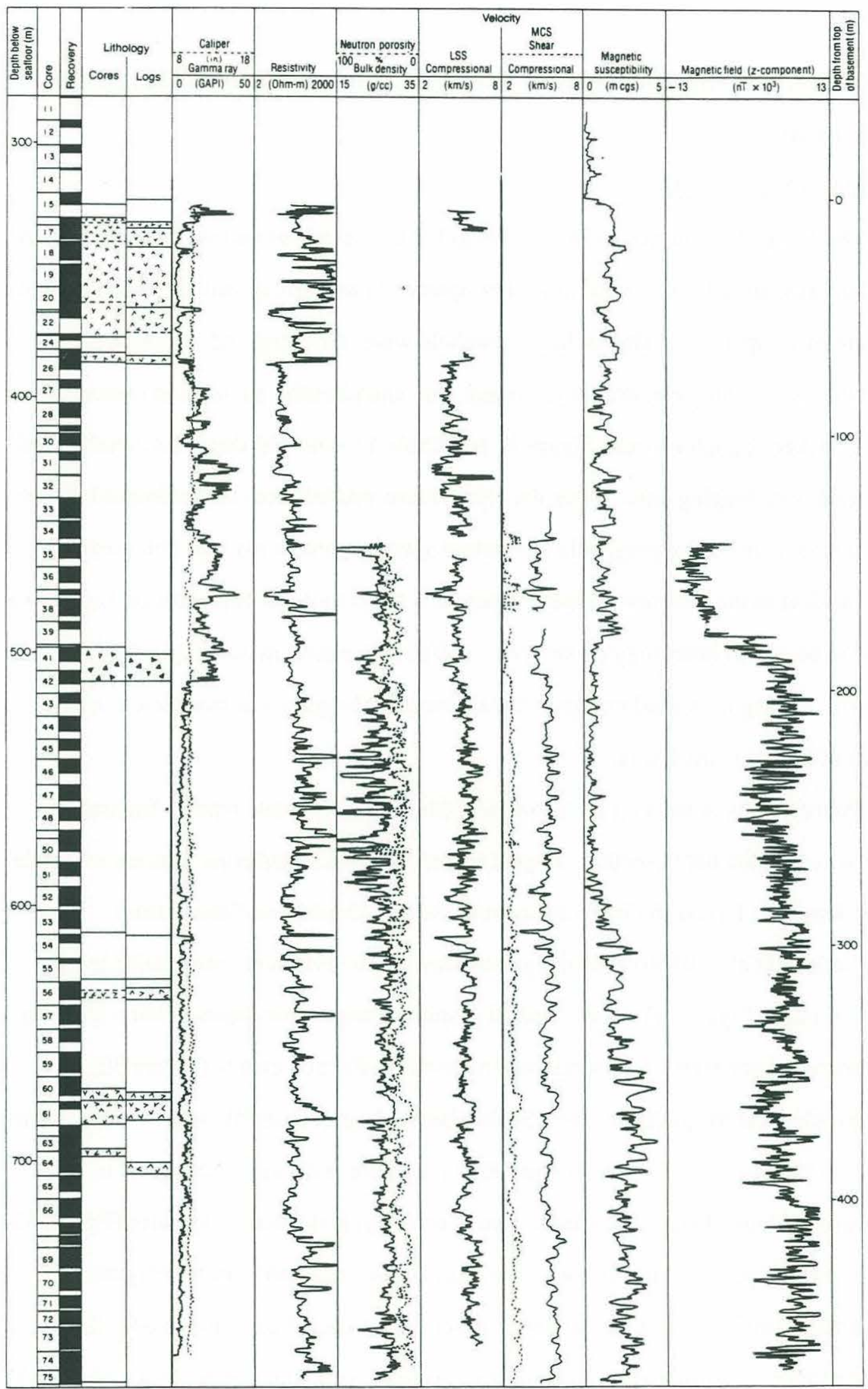

. Lithology and logging data obtained in Hole 418A on Leg 102 (Shipboard Scientific Party, 1986). Pillow basalt $=$ no symbol; massive basalt $=$ carets; breccia $=$ triangles . 
Figure 29. Gamma ray logs in sediment section of Hole $418 \mathrm{~A}$ from Carlson et a1. (1988b).

81
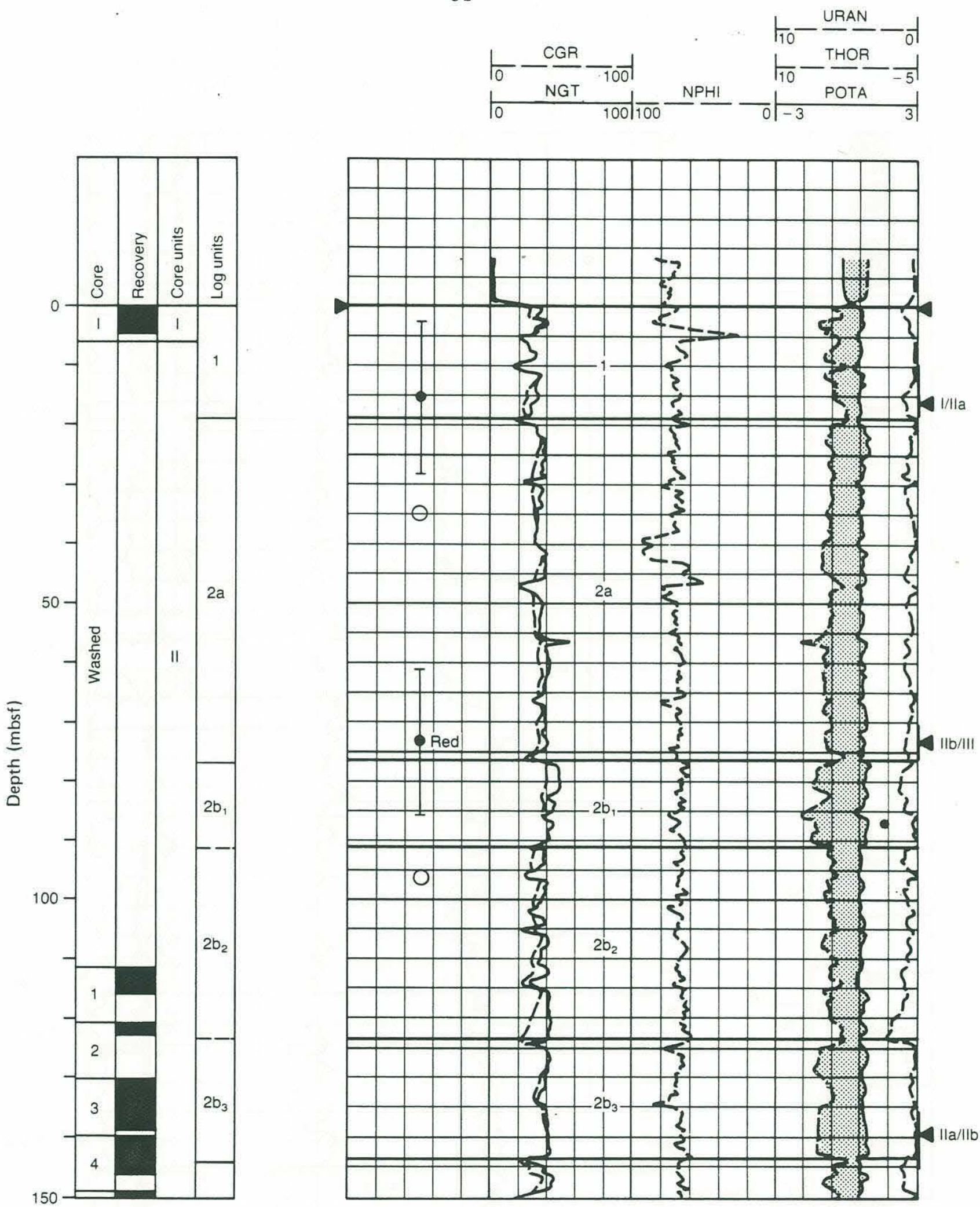

Coring and logging stratigraphy, Site 418. Logs shown are total standard gamma-ray (NGT $=U+T h+K)$ and calculated gamma-ray (CGR $=K+T h$ ) (GAPI units), uranium and thorium (ppm), potassium (weight \%), and apparent (raw) neutron porosity (NPHI, \%). On the left are the Hole 418A coring and recovery records, lithologic units denoted by Roman numerals, and log units denoted by Arabic numerals. Solid triangles on left and right margins of the downhole log indicate depths to lithologic boundaries in Holes $418 \mathrm{~A}$ and $418 \mathrm{~B}$, respectively; associated heavy vertical bars show possible ranges of depth. Heavy horizontal lines across logs indicate log-unit boundaries. Light lines indicate log subunits. Circles in left column of log show calculated depths corresponding to reflection events; solid circles show primary events and open circles, second pulses. Error bars show uncertainty of $\pm 13 \mathrm{~m}$ in calculated depths. 
Figure 29 continued.

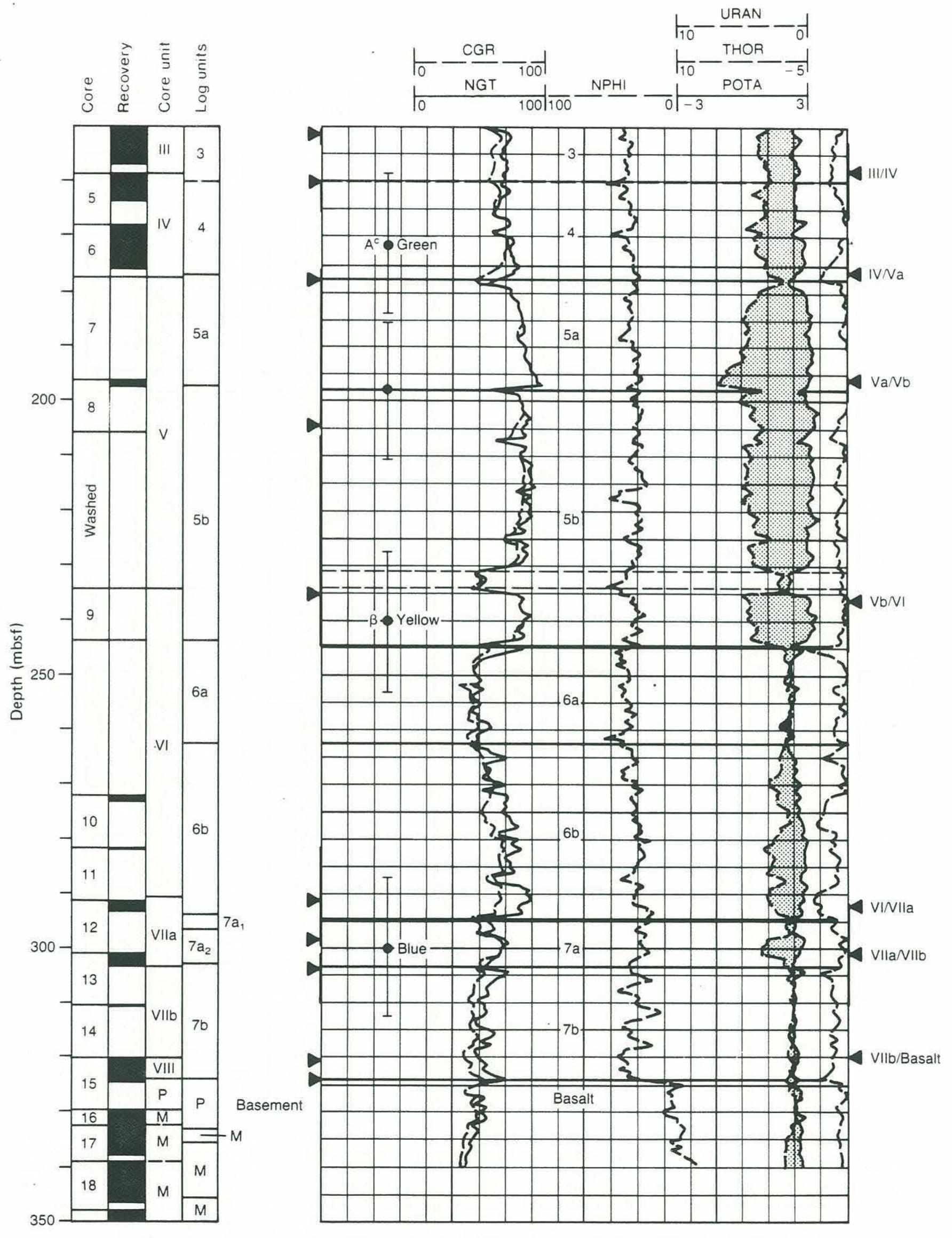


Figure 30. Correlation of gama ray log with reflection profile from Carlson et al. (1988b).

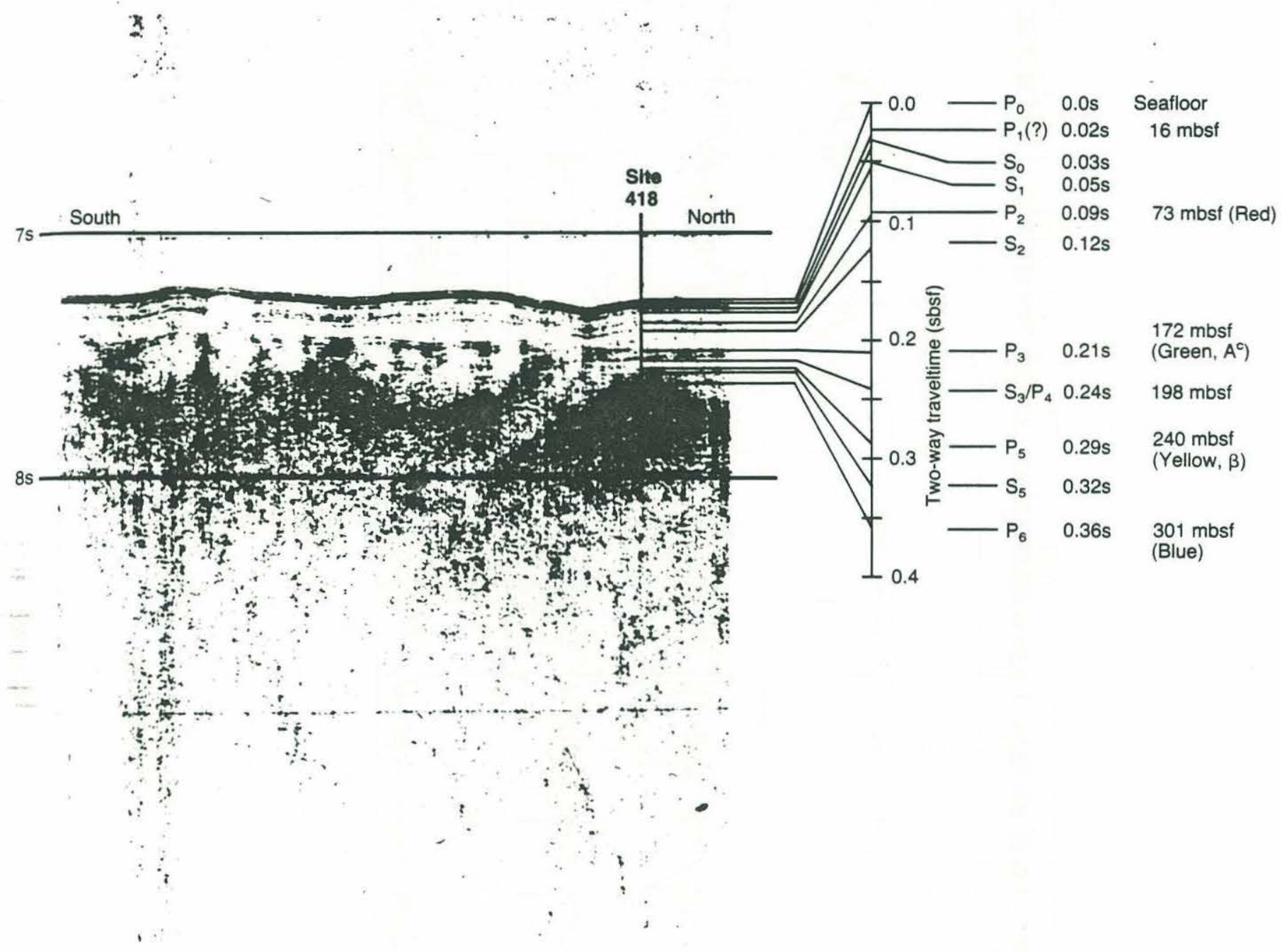

Interpreted reflection profile across Site 418. $\mathrm{P}$ indicates primary event. $\mathrm{S}$ indicates second pulse. Subscripts denote reflectors (i.e., $\mathrm{P}_{2}$ and $\mathrm{S}_{2}$ represent the same reflecting horizon). The existence of $P_{1}$ is inferred from $S_{1}, P_{4}$ is partly masked by $S_{3}$. 
Figure 31. Schlumberger logging data at Hole 418A from Broglia and Moos (1988).
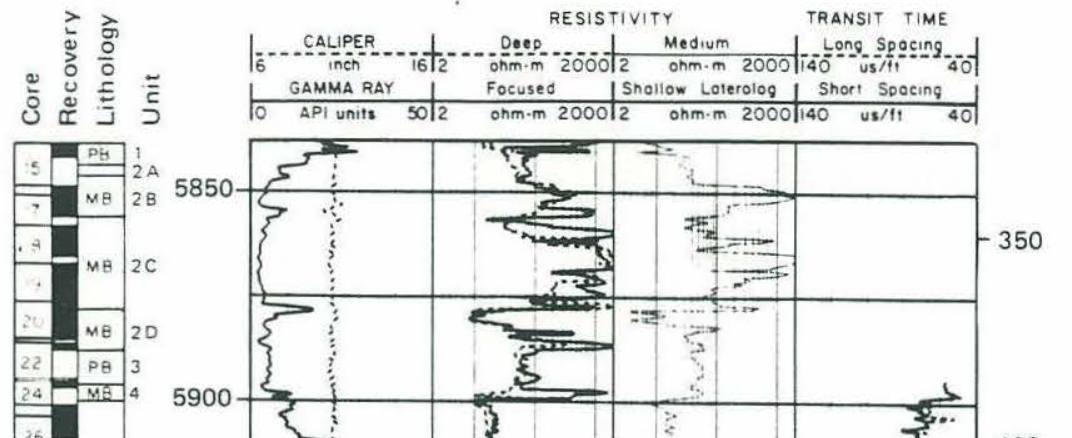

\begin{tabular}{|l|}
\hline 27 \\
\hline 28 \\
\hline 3 \\
\hline
\end{tabular}

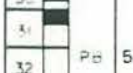

3

34

35

\begin{tabular}{|l|}
\hline 36 \\
\hline 38 \\
\hline
\end{tabular}

38 . 39

(1) $6 \mathrm{~A}$

\begin{tabular}{|l|l|}
\hline 42 & \\
\hline 43 & \\
\hline 4 & \\
\hline
\end{tabular}

5900

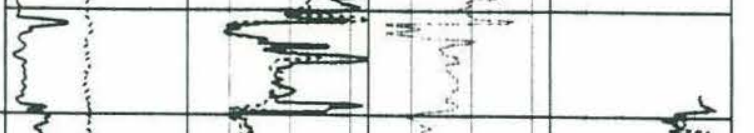

44

45

\begin{tabular}{ll}
46 & \\
\hline &
\end{tabular}

\begin{tabular}{|l|}
\hline 47 \\
\hline 48 \\
\hline
\end{tabular}

48

50

51

52

\begin{tabular}{|l|l|l|}
\hline 5 & \\
\hline 54 & & \\
\hline 5
\end{tabular}

$55-18$

56

$\rightarrow$

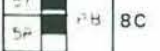

$\div 9$

\begin{tabular}{llll}
\hline 60 & & & \\
\hline 98 & 9
\end{tabular}

61

.3 11

6. 3 ME 12

$65=P B \quad 13 \mathrm{~A}$

is

\begin{tabular}{ll}
1386250 \\
\hline 68
\end{tabular}

69

70

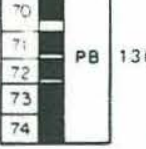

6200

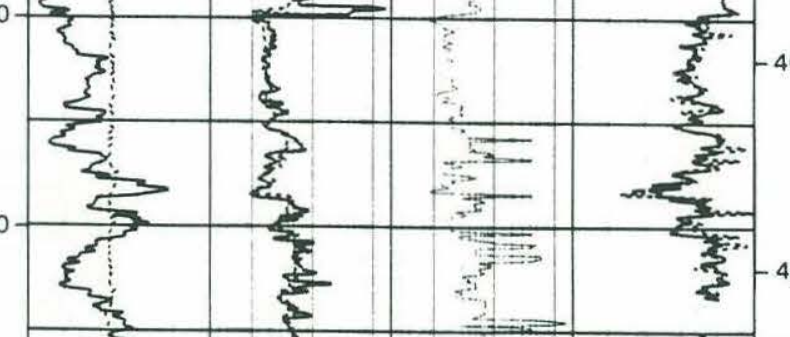

6100

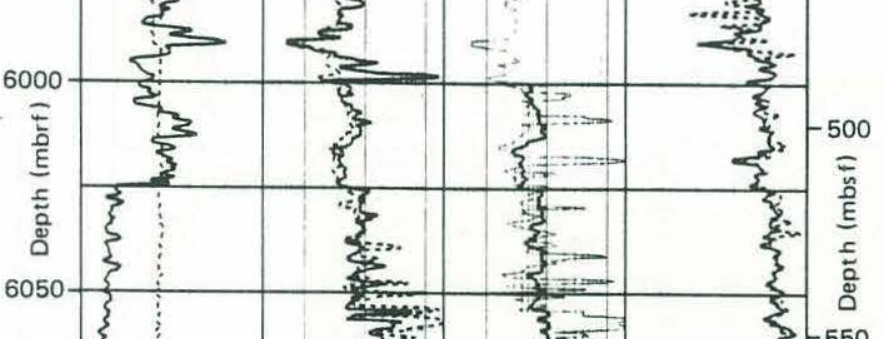

150

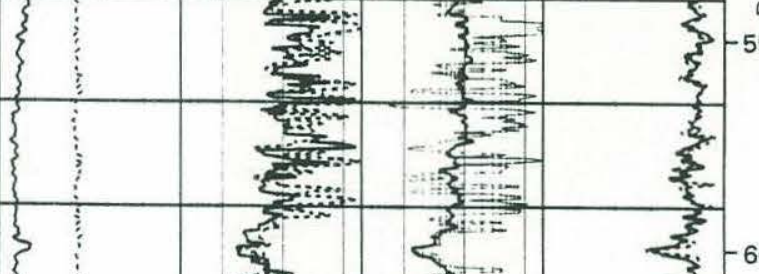

Core recovery, log-determined lithology, and logging data as a tunction of depth in Hole 418A. Sediment/basement contact at 324 mbsf. Gamma-ray curve corrected for borehole conditions (see text). Sonic data from 324 to 384 mbsf were recomputed from the full waveforms (see Fig. 7), as the original data were affected by frequent cycle skipping. No data were recorded between 456 and $465 \mathrm{mbsf}$. Logging data are smoothed by using a 5 -point running average $(0.75-\mathrm{m}$ depth interval $) . \mathrm{PB}=$ pillow basalt; $\mathrm{MB}=$ massive basalt; $\mathrm{B}=$ breccia . 
Figure 31 continued.

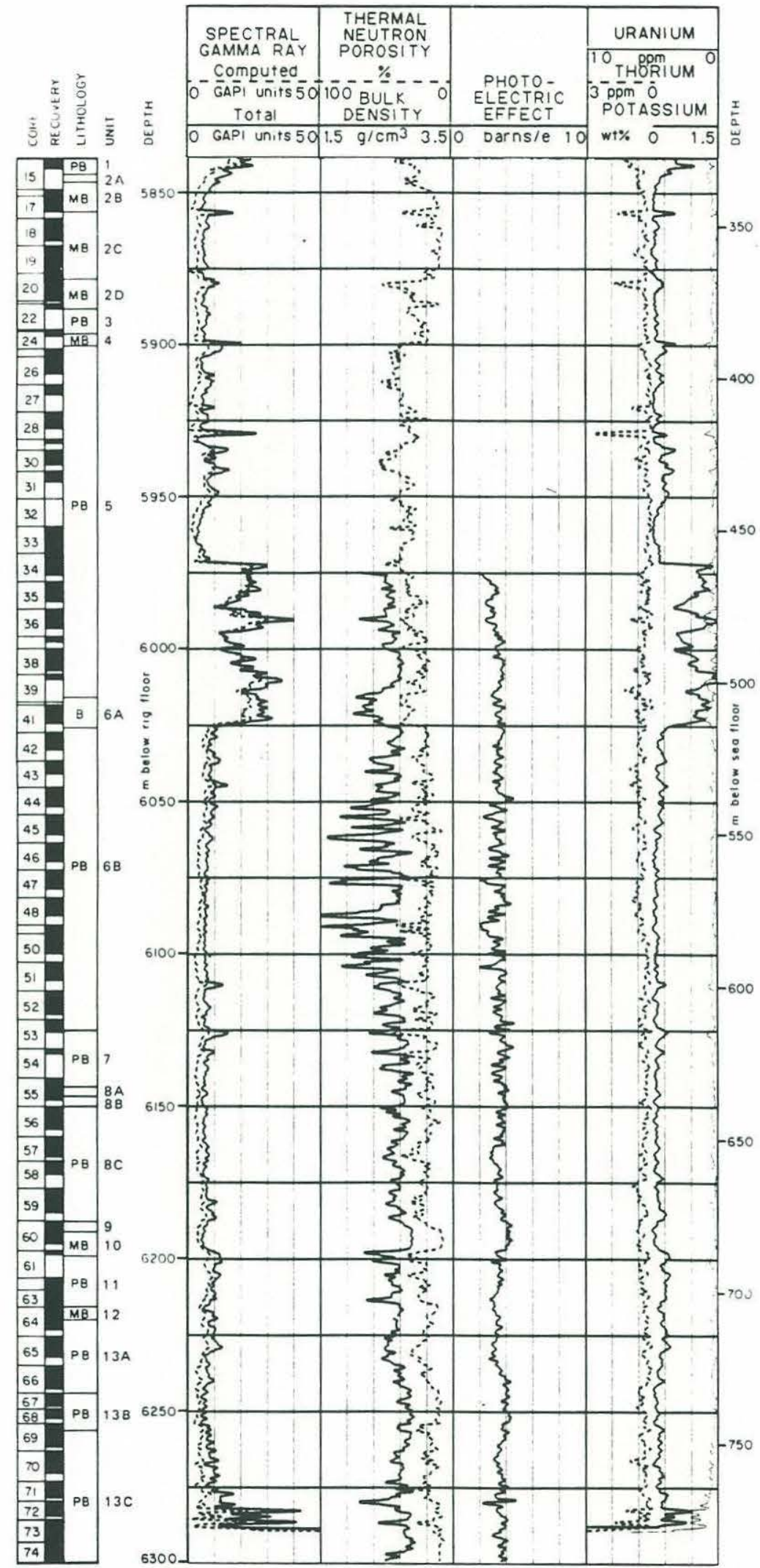

Core recovery, log-determined lithology, and logging data as a function of depth in Hole 418A. Spectral gamma-ray and neutron logs were run through the pipe from 324 to 464 mbsf. Neutron and density logs are corrected for borehole conditions (see text). Logging data are smoothed by using a 5-point running average $(0.75-\mathrm{m}$ depth interval). $\mathrm{PB}=$ pillow basalt; $\mathrm{MB}=$ massive basalt; $\mathrm{B}=$ breccia. 
Figure 32. Computed smectite volume, total porosity, and primary porosity in Hole 418A from Broglia and Moos (1988).

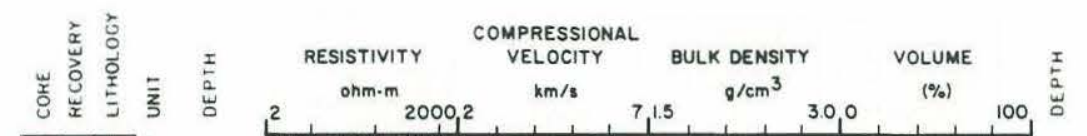

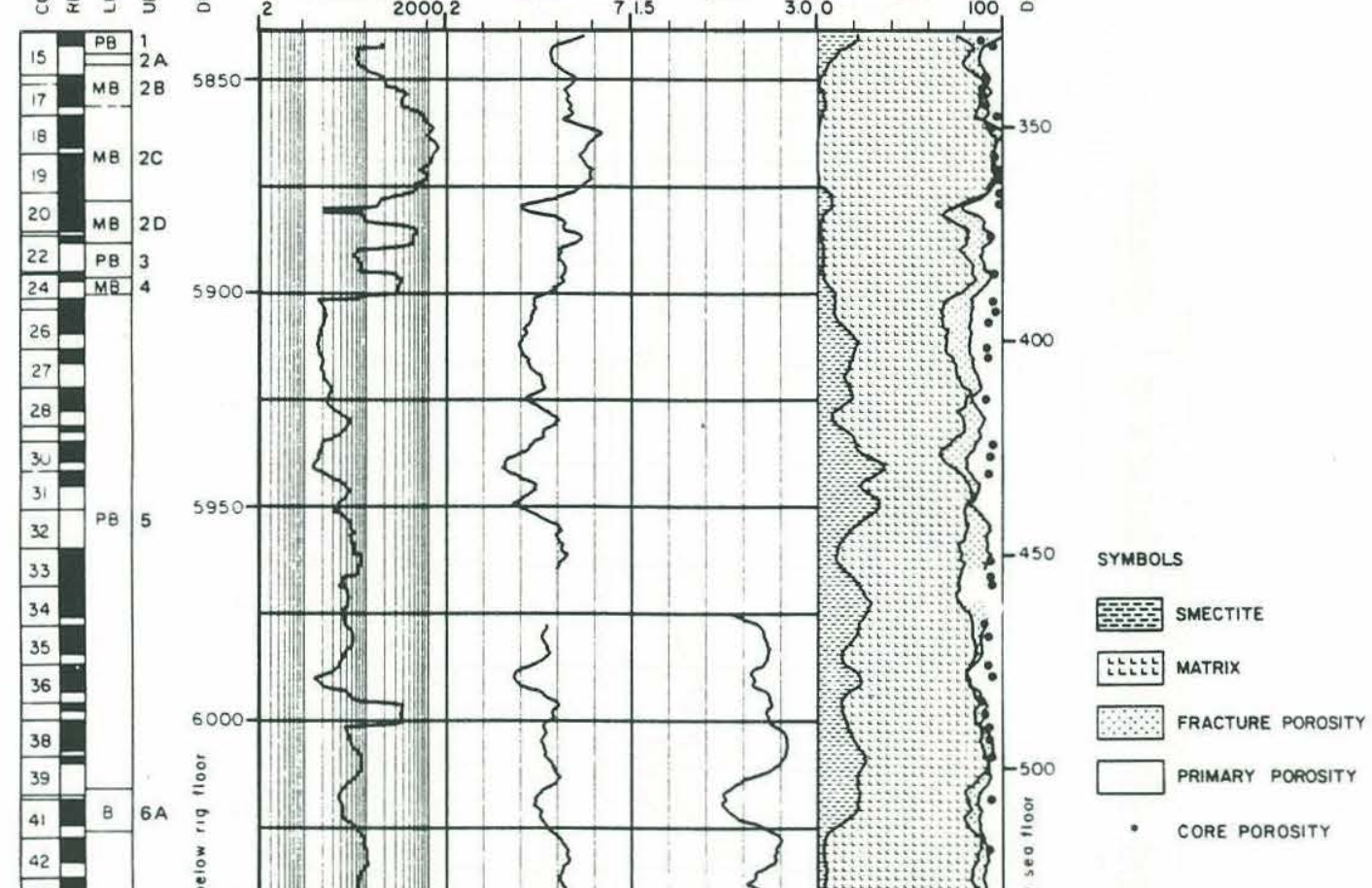


Figure 33. Upper and lower limits on the riginal basment porosity and velocity computed from log data in Broglia and Moos (1988).
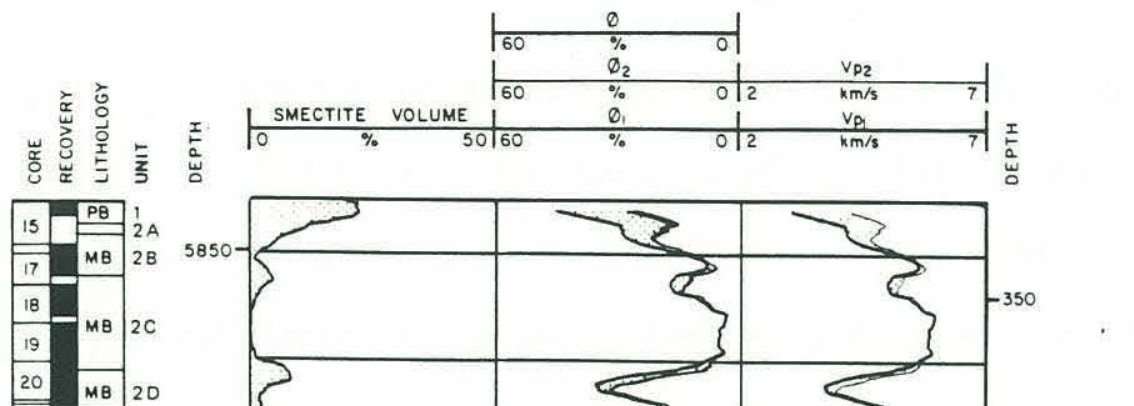
Moos (1988) used 12-channel sonic wave forms to compute velocity, energy, and frequency content of P, S, and Stoneley waves (Figures 34 and 35). All parameters show dependence on lithology. $\mathrm{P}$ and $\mathrm{S}$ velocities are almost independent of borehole depth, whereas Stoneley wave velocities increase downward by $\sim 7 \%$. Maximum shear and compressional energy also increase systematically with depth.

Carlson et al. (1988a) examined the relationship between density and velocity measured by logging. The relationship for $418 \mathrm{~A}$ logs agrees well with laboratory data. Because agreement was not found in a previous study for DSDP holes drilled in crust younger than $20 \mathrm{Ma}$, they argue that the relationship between crustal properties changes with age. They do not comment on the fact that a similar data set from Hole 417D (Salisbury et al., 1980a) appears to agree better with the younger crustal holes than with 418A.

Wilkins et al. (1988) cross plot formation factor, tortuosity, and a velocity-porosity ratio computed from log data. They argue that, with better log data, such plots may be used to discriminate lithologies and formation physical properties.

Bosum and Scott (1988) found that the downhole changes in magnetic susceptibility and total magnetization (Figure 36) correspond with lithology changes and agree well with laboratory measurements. In particular, they confirm the magnetic reversal boundary at $185 \mathrm{~m}$ sub-basement depth (breccia, unit 6a). Computed magnetic pole positions agree with the apparent polar wandering paths for North America.

Salisbury et al. (1988) summarize results from Leg 102 logging. They compute average properties for the upper $0.5 \mathrm{~km}$ of crust: $86 \%$ basalt, $9 \%$ alteration products and vein filling, and 5\% seawater filled cracks. They subdivide basalts into $69 \%$ pillows, $17 \%$ massive flows, and $4 \%$ cemented breccias. The basalts themselves contain vesicular and grain boundary porosity which increases the total formation porosity to $15 \%$. Units with highest porosity values ( 5 and $6 \mathrm{~A}$ ) have formation porosity of $20 \%$ (14\% primary, $6 \%$ 
Figure 34. Basement velocity data trom multichannel logging at Hole 418A by Moos (1988).

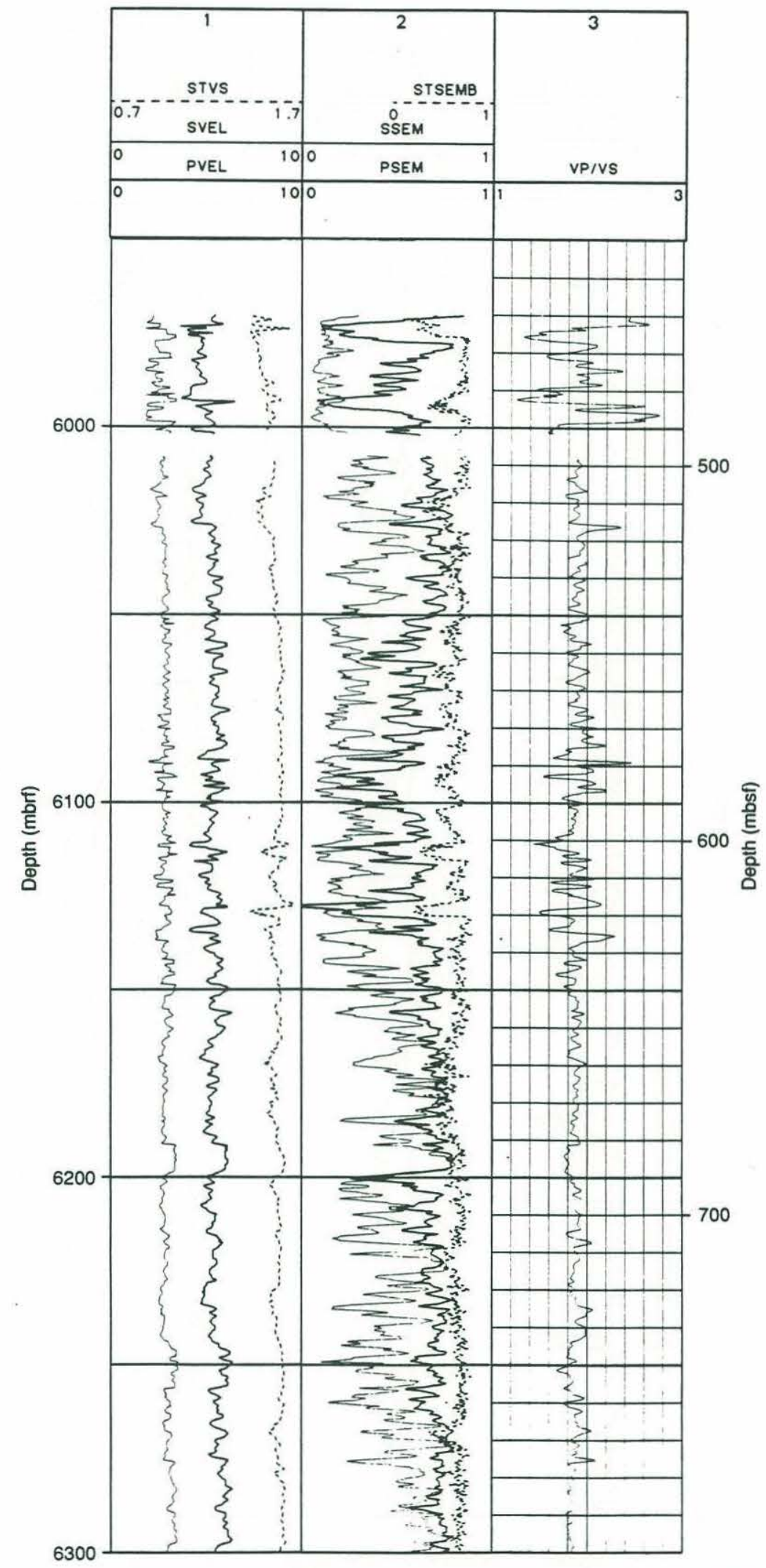

Compressional- (PVEL) and shear- (SVEL) wave velocities and $\mathrm{V}_{p} / \mathrm{V}_{s}(\mathrm{VP} / \mathrm{VS})$ for Hole 418A, compressional (PSEM) and shear (SSEM) semblances, and Stoneley velocity (STVS) and semblance (STSEMB) as a function of depth in Hole 418A. No data were recorded between $489-499$ mbsf. Data were averaged over 1.5 -m intervals. Semblance varies between 0 and 1 , where 1 is perfect coherence. Decreased semblance is due to loss of energy of the primary arrival by scattering or intrinsic attenuation or from interference from secondary phases within the semblance window. Velocities in $\mathrm{km} / \mathrm{s}$. 
Figure 35. Peak frequency and energy in $\mathrm{P}$ and $\mathrm{S}$ waves in Hole 418A from Moos (1988).

90

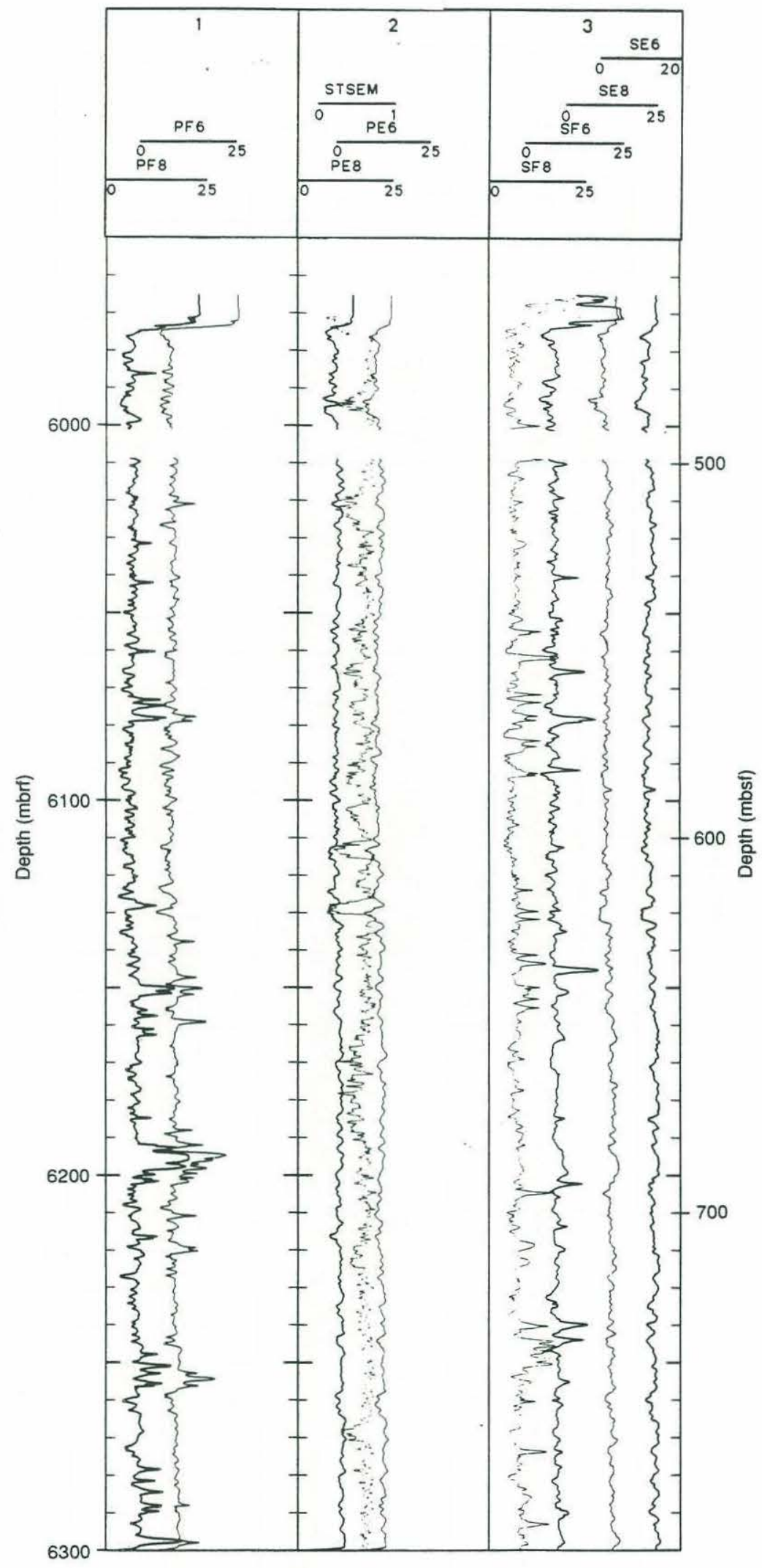

Peak frequency $(\mathrm{F}$, in $\mathrm{Hz})$ and energy $(\mathrm{E}$, in $\mathrm{dB})$ plots for $P(\mathrm{P})$ and $S(\mathrm{~S})$ waves at receivers 6 and 8 , with Stoneley semblance (STSEM) as a function of depth in Hole 418A. Higher peak frequencies occur within massive Subunit 8A (632-636 mbsf), Unit 9 (676-679 mbsf), Unit 10 (679-686.5 mbsf), and massive pillow Subunit 13B (731.5-743.8 mbsf). Higher peak frequencies are also measured in short sections not identified as massive units from core descriptions (e.g., within Subunit 13C below 744 mbsf). Peak energy increases somewhat with increasing depth. 
Figure 36. Sediment and basement magnetic logs from ODP Leg 102/ Hole 418A by Bosum and Scott (1988).
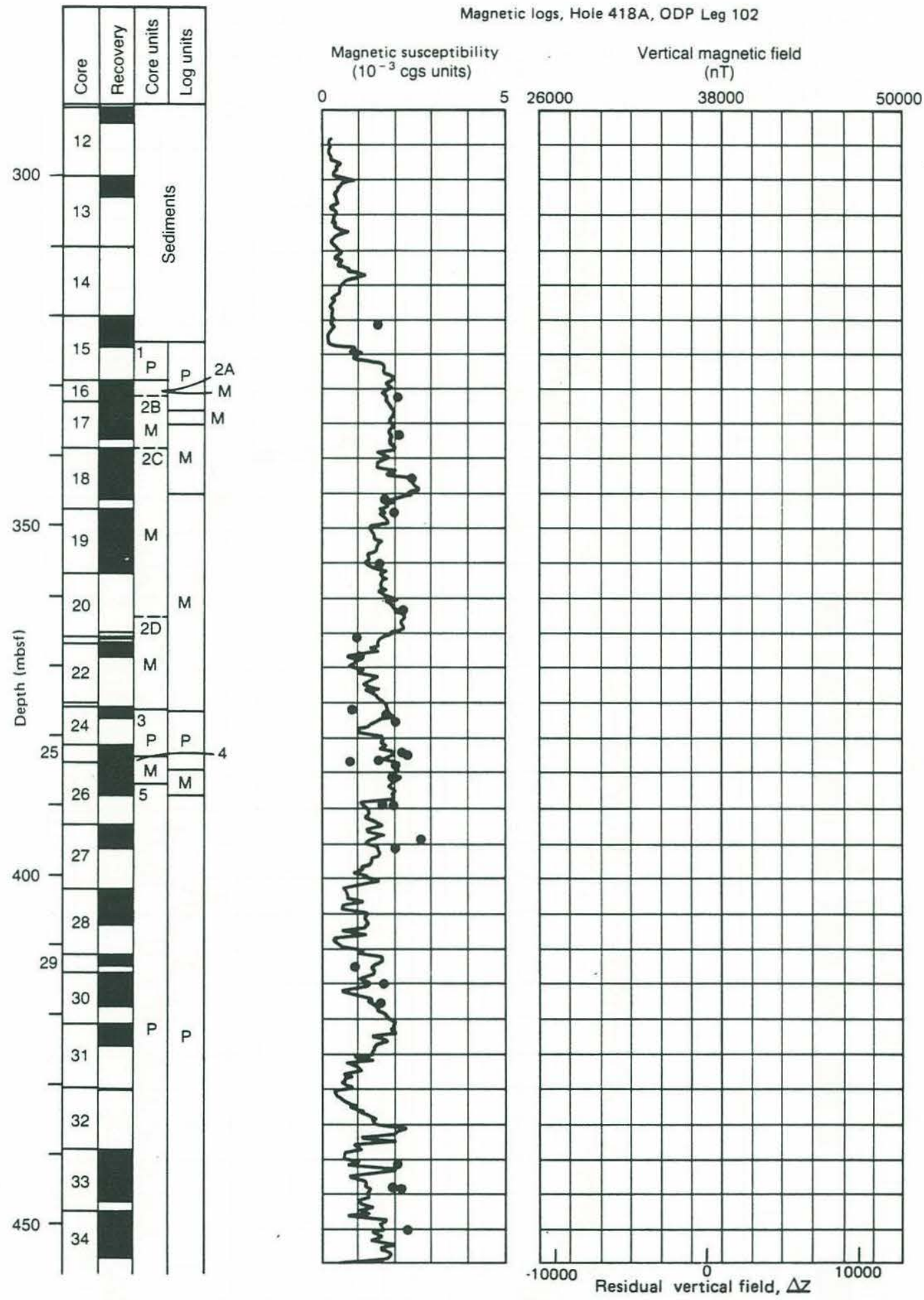

(nT)

Lithologic and magnetic logging data from basement rocks and lower sediments, Hole 418A. Logging data smoothed with a 5-point Hamming filter with an effective length of $1 \mathrm{~m}$. Lithologic interpretation of core units after Donnelly, Francheteau, et al. (1980) and log units after Broglia and Moos (this volume) in track 1. Susceptibility log and lab data in track 2; vertical component magnetometer log in track 3. 
Figure 36 continued.
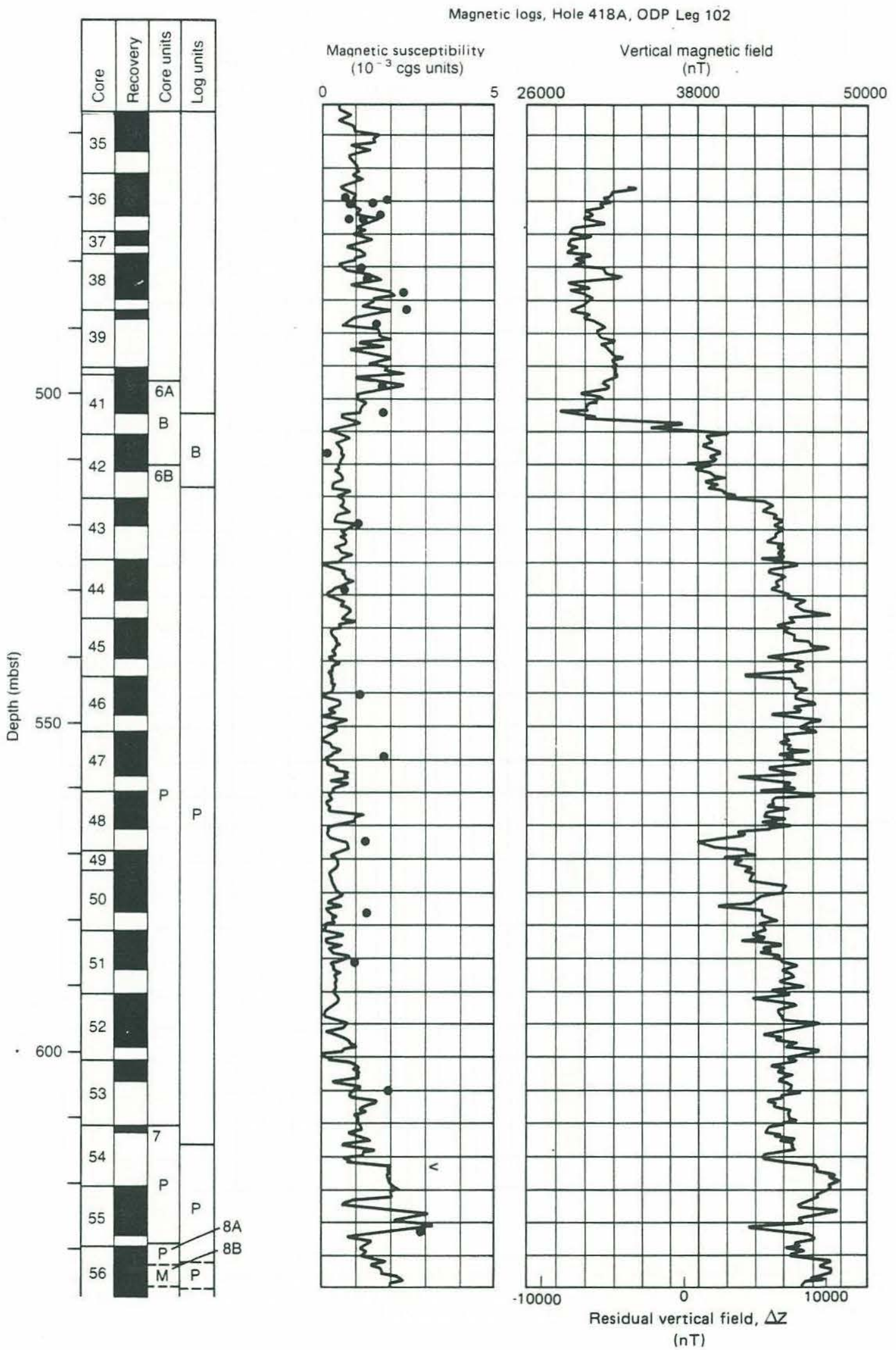
Figure 36 continued.

Magnetic logs, Hole 418A, ODP Leg 102
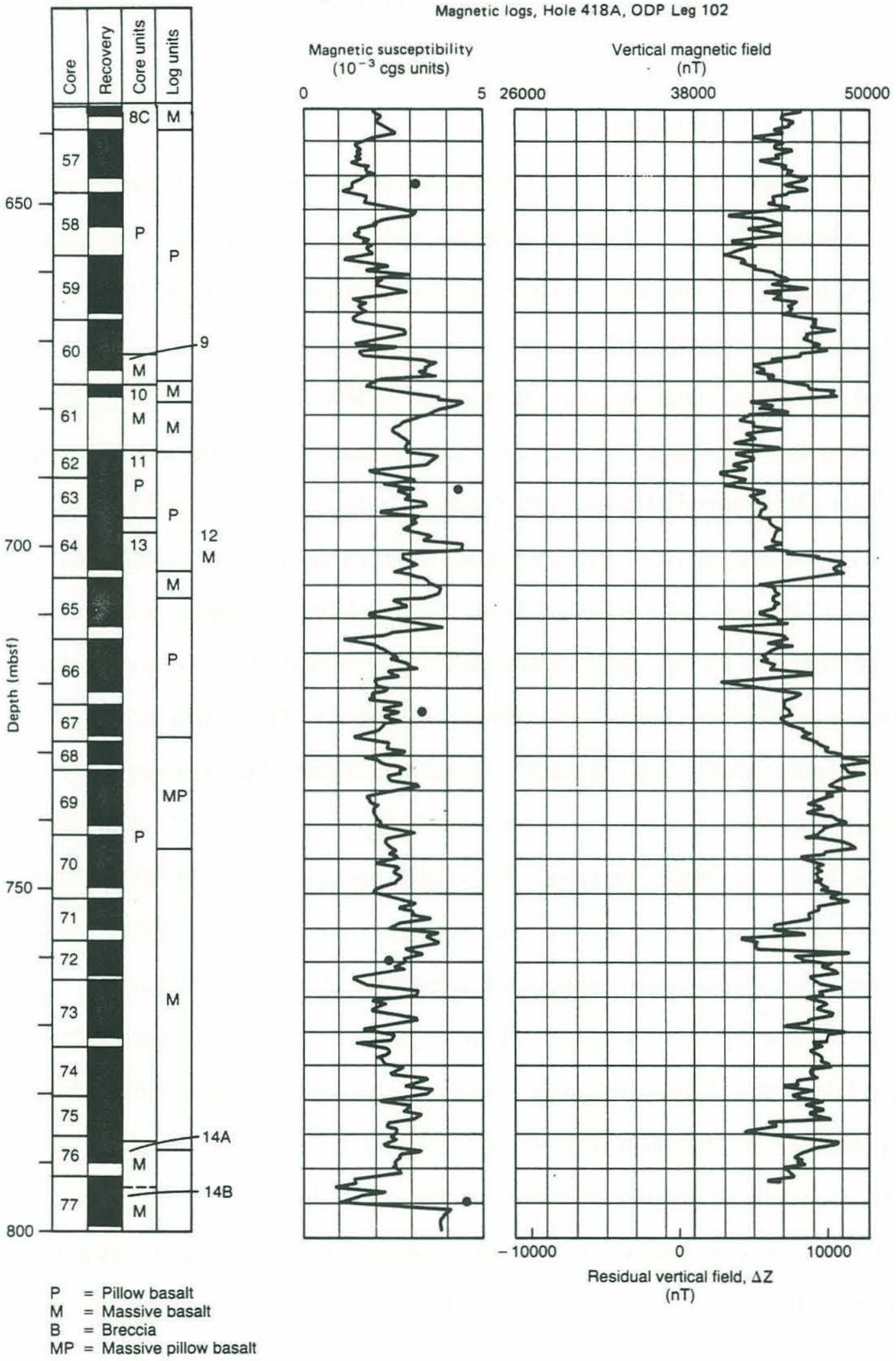

$P=$ Pillow basalt

$M=$ Massive basalt

$B=$ Breccia

MP = Massive pillow basalt 
cracks) and $19 \%$ clay content. They estimate formation porosity at time of emplacement was $\sim 40 \%$.

\section{BOREHOLE SEISMIC EXPERIMENTS}

Oblique seismic experiments with a three component seismometer were conducted in Hole 417D on DSDP Leg 52 (2 clamping depths, 165 shots; Stephen et al. 1980a,b) and in Hole 418A, located $7.5 \mathrm{~km}$ away, on ODP Leg 102 (5 clamping depths, 3296 shots; Swift et al., 1988; Swift and Stephen, in press). P-wave travel times were inverted by the $\tau-\zeta$ method for velocity assuming lateral homogeneity (Table 12; Stephen and Harding, 1983; Swift and Stephen, in press). Velocities were also determined by the inflection point method (Table 13). Figure 37 shows $\mathrm{P}$ and $\mathrm{S}$ (assuming $\mathrm{V}_{\mathrm{p}} / \mathrm{V}_{\mathrm{S}}=1.82, \sigma=0.28$ ) velocities at Hole 418A. Since the 95\% confidence limits on depth for 417D and 418A overlap (Figure 38), Swift and Stephen (in press) concluded that the average crustal velocity properties near the two sites are not significantly different. There is an indication of lateral heterogeneity in the P-wave travel times at Hole 418A. Travel time anomalies suggest that seismic velocity in the upper $0.5 \mathrm{~km}$ increase towards the northwest out to $\sim 5$ $\mathrm{km}$ shooting range, although the nature of the anomaly is poorly constrained (Figure 39 and Table 14; Swift and Stephen, in press). The vertical gradients in velocity determined by sonic log and oblique seismic experiment do not agree well (Figure 40). Taking these results at face value, we may infer that the vertical sequence of lithogy and degree of alteration observed at $418 \mathrm{~A}$ may not represent the properties of the crust averaged laterally over several kilometers. Travel-time analyses at both holes show no evidence for crustal anisotropy, although measurement error at $418 \mathrm{~A}$ could mask anisotropy of up to $0.2-0.3$ $\mathrm{km} / \mathrm{s}$ (Table 15; Swift and Stephen, in press). Preliminary analyses of ambient noise spectra in the $2-30 \mathrm{~Hz}$ band indicate that only the most quiet 3-second windows are as quiet

as that observed during the Ngendie Experiment (Figure 41; Stephen and Swift, 1986). 
From Swift and Stephen (in press)

Table 12 Results of $\tau-\zeta$ inversion.

Velocity Depth Minimum Depth Maximum depth

$(\mathrm{km} / \mathrm{s}) \quad(\mathrm{km}) \quad(\mathrm{km}) \quad(\mathrm{km})$

Hole 418A (This paper)
$\begin{array}{ll}4.545 & 0.0\end{array}$
$5.181 \quad 0.408$
0.197
0.619
$5.747 \quad 0.883$
0.696
1.070
$6.211 \quad 1.380$
1.045
1.716
$6.803 \quad 1.756$
1.614
1.897

Hole 417D (Stephen and Harding, 1983)

$\begin{array}{llll}4.400 & 0.0 & & \\ 5.025 & 0.353 & 0.193 & 1.514 \\ 5.682 & 0.698 & 0.592 & 0.804 \\ 6.623 & 1.487 & 1.339 & 1.635\end{array}$

Table 13 Inflection point ranges and velocities from cubic spline fits to radial line data.

\begin{tabular}{|c|c|c|c|c|}
\hline \multirow[b]{2}{*}{$\begin{array}{l}\text { Geophone } \\
\text { Depth }\end{array}$} & \multicolumn{2}{|c|}{$\begin{array}{c}\text { Before Correction } \\
\text { to basement }\end{array}$} & \multicolumn{2}{|c|}{$\begin{array}{c}\text { After Correction } \\
\text { To Basement }\end{array}$} \\
\hline & $\begin{array}{l}\text { Range } \\
(\mathrm{km})\end{array}$ & $\begin{array}{l}\text { Velocity } \\
(\mathrm{km} / \mathrm{s})\end{array}$ & $\begin{array}{l}\text { Range } \\
(\mathrm{km})\end{array}$ & $\begin{array}{r}\text { Velocity } \\
(\mathrm{km} / \mathrm{s})\end{array}$ \\
\hline 41 & 4.7 & 4.60 & 3.2 & 4.81 \\
\hline 81 & 3.2 & 4.63 & & \\
\hline 230 & 4.5 & 4.86 & 3.0 & 5.10 \\
\hline 330 & 4.4 & 4.86 & 3.2 & 5.07 \\
\hline 430 & 5.0 & 4.95 & 3.8 & 4.99 \\
\hline
\end{tabular}


Figure 37. $\mathrm{P}$ and $\mathrm{S}$ velocity profiles for Hole 418A from the oblique 1seismic experiment (Swift and Stephen, in press). Circles and triangles are inflection point velocitiesfrom travel time-range relations cbefoer and after reduction of travel times to basement, respectively. Dashed lines are the $95 \%$ confidence limits on the $P$ velocity profile obtained by tau-zeta inversion of $\mathrm{P}$ travel times. S velocity profile from trial and error travel time modeling and amplitude relations in reflectivity seismograms. $\mathrm{Vp} / \mathrm{Vs}=1.82 ;$ Poison.'s ratio $=0.26$.

VELOCITY $(\mathrm{km} / \mathrm{s})$

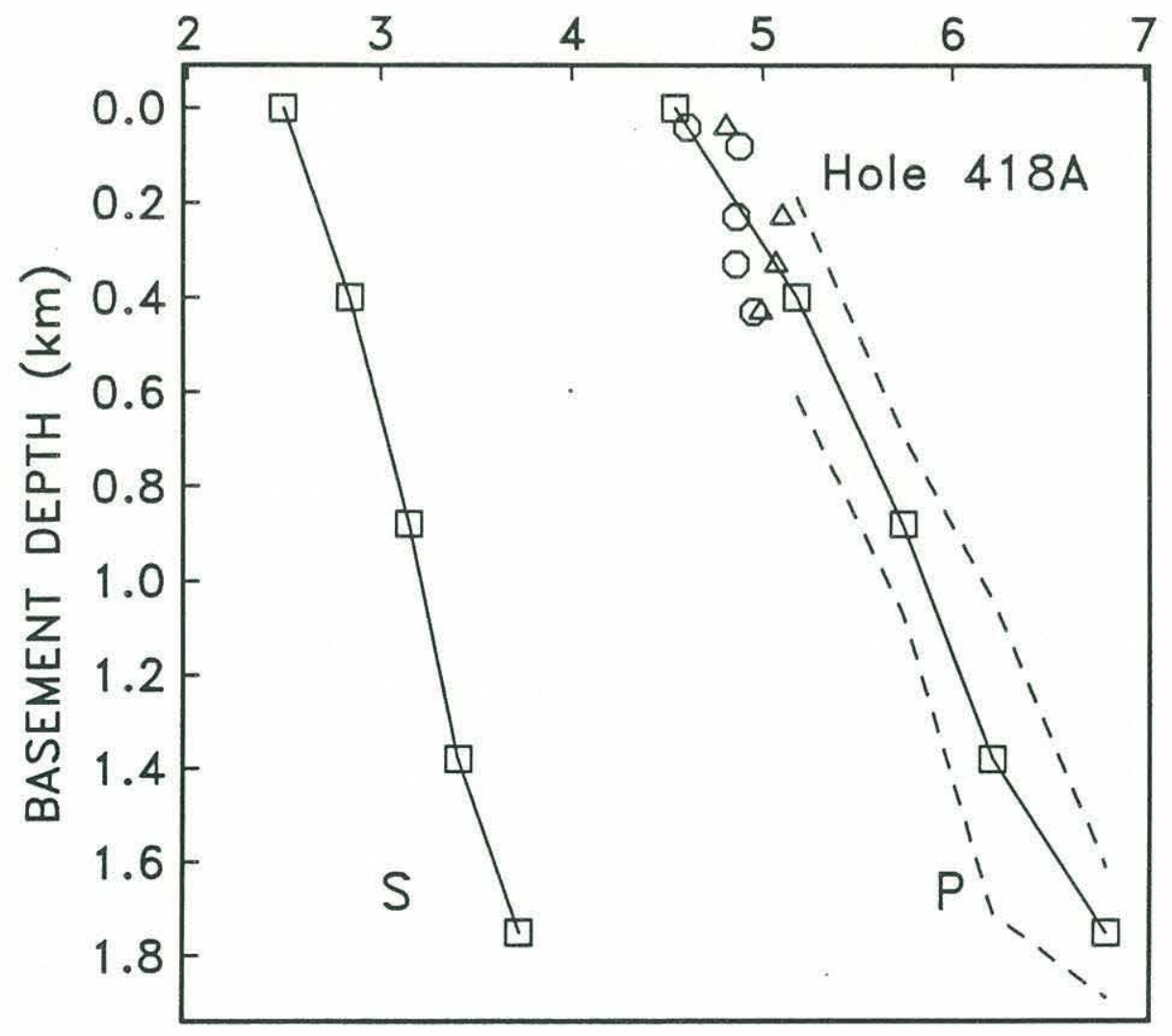


Figure 38. Comparison of P velocity profiles from Hole 417D (Stephen and Harding, 1983) and 418A (Swift and Stephen, in press). Velocities from tau-zeta inversion of $B$ travel times. Lines not connecting symbols are the $95 \%$ confidence limits on depth.

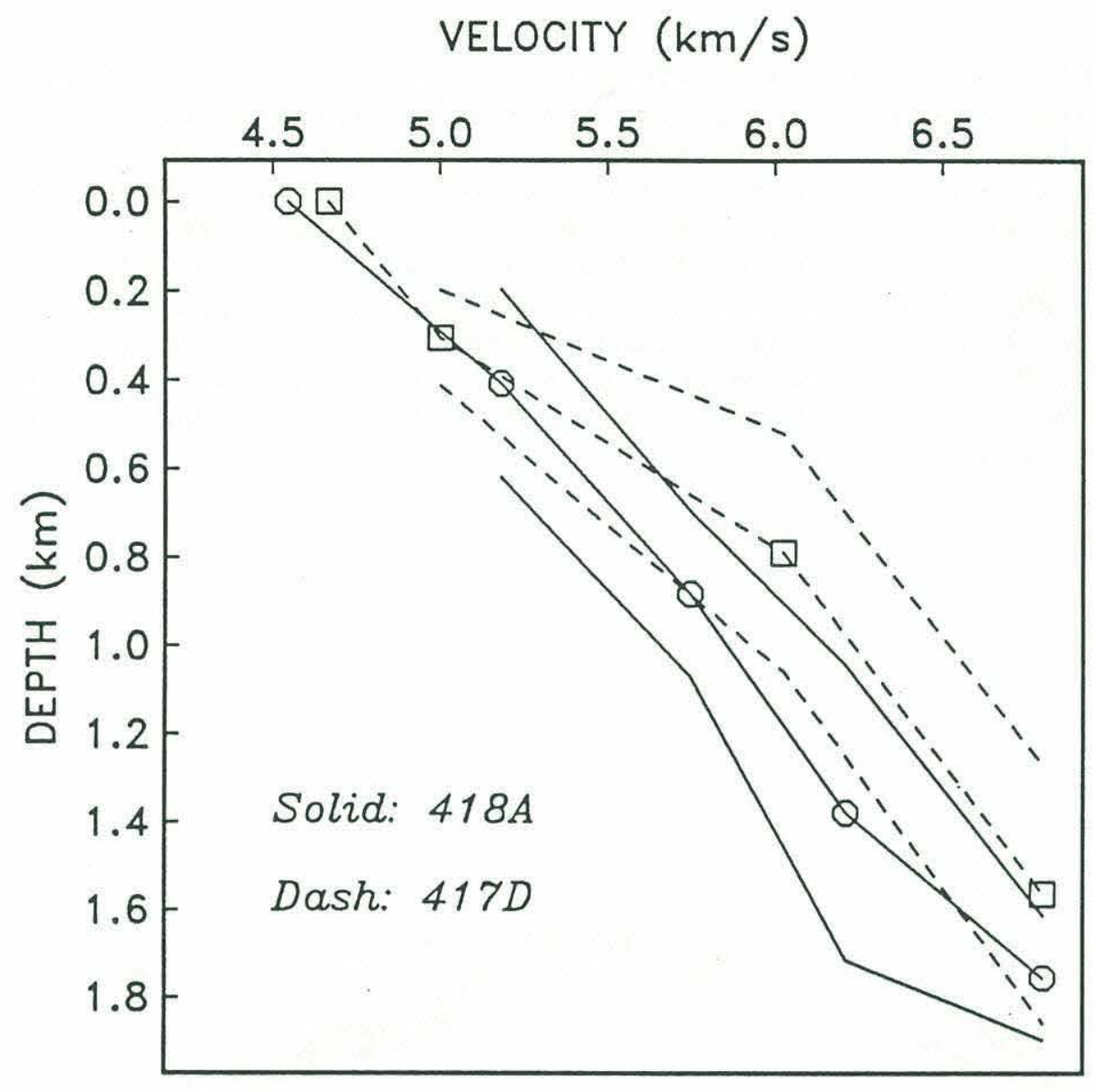


Figure 39. Comparison of arrivals determined by raytracing through two laterally heterogeneous structures with arrivals for the receiver at $330 \mathrm{~m}$ depth and a shooting range of $4 \mathrm{~km}$. Solid line is the one theta fit from harmonic analysis. Short dashed line a indicates arrivals from shots at $1.9 \mathrm{~km}$ range using a linear notthward velocity gradient of $0.761 / \mathrm{sec}$ tied to a borehole velocity of $5.06 \mathrm{~km} / \mathrm{s}$ (Table14 bottom). Long dashed line depicts arrivals at $1.9 \mathrm{~km}$ range using a step discontinuity model with $4.6 \mathrm{~km} / \mathrm{s}$ to the south and $6.8 \mathrm{~km} / \mathrm{s}$ to the north (Table 7). Discontinuity is offset by $0.2 \mathrm{~km}$ to the north of the borehole. From Swift and Stephen (in press).

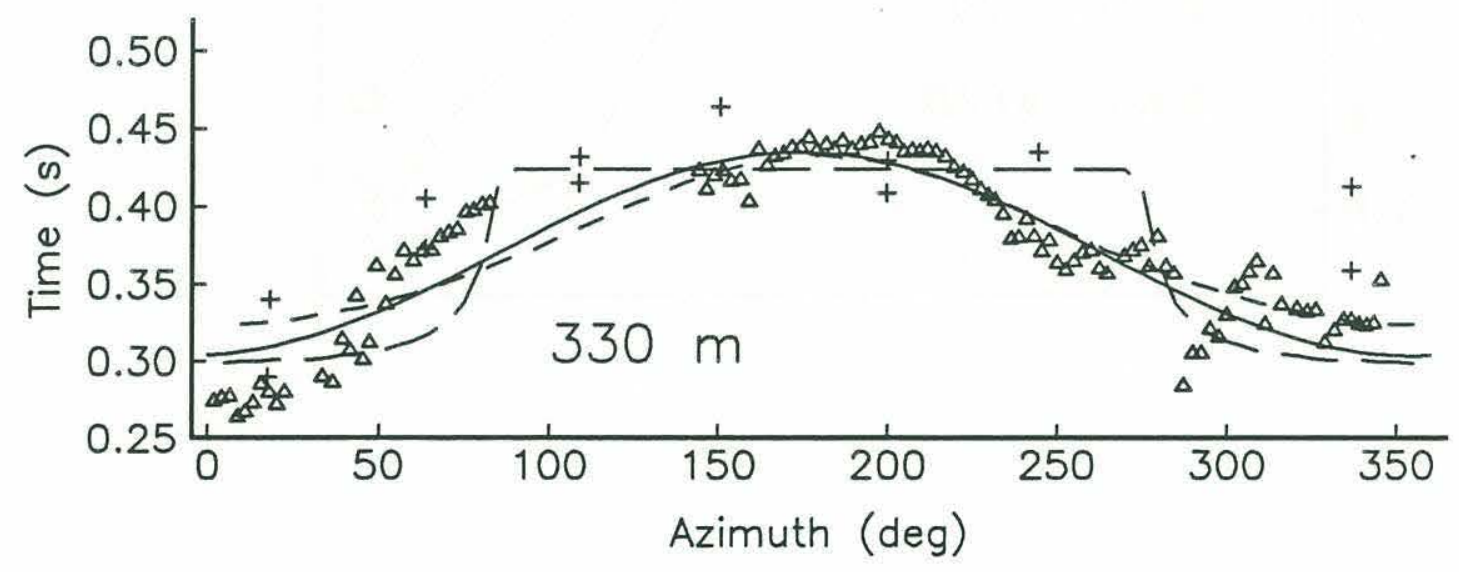


Table 14 Lateral velocity contrast inferred from the $1 \theta$ travel time anomalies in the 2 and 4 $\mathrm{km}$ shooting range circles. Velocity variation modeled as a vertical discontinuity between two laterally and vertically homogeneous slabs.

\begin{tabular}{|c|c|c|c|c|c|c|c|}
\hline \multirow{2}{*}{$\begin{array}{l}\text { Receiver } \\
\text { Depth } \\
(\mathrm{m})\end{array}$} & \multirow{2}{*}{$\begin{array}{c}\text { Basement } \\
\text { Range } \\
(\mathrm{km})\end{array}$} & \multirow{2}{*}{$\begin{array}{c}\text { Average } \\
\text { Travel } \\
\text { Time (s) }\end{array}$} & \multirow{2}{*}{$\begin{array}{c}\text { 10 } \text { Travel }^{1} \\
\text { Time } \\
\text { Anomaly (s) }\end{array}$} & \multirow{2}{*}{$\begin{array}{l}\text { Interpolated } \\
\text { Velocity } \\
(\mathrm{km} / \mathrm{s})\end{array}$} & \multicolumn{2}{|c|}{ Velocity } & \multirow{2}{*}{$\begin{array}{l}\text { Velocity } \\
\text { Contrast } \\
(\mathrm{km} / \mathrm{s})\end{array}$} \\
\hline & & & & & $\begin{array}{l}\text { North } \\
(\mathrm{km} / \mathrm{s})\end{array}$ & $\begin{array}{l}\text { South } \\
(\mathrm{km} / \mathrm{s})\end{array}$ & \\
\hline 230 & 0.646 & 0.133 & 0.0 & 4.90 & 5.67 & 4.25 & 1.42 \\
\hline 230 & 2.103 & 0.377 & 0.05502 & 4.90 & 6.53 & 4.87 & 1.66 \\
\hline 330 & 0.614 & 0.139 & 0.01169 & 5.06 & 4.82 & 4.07 & 0.75 \\
\hline 330 & 2.045 & 0.369 & 0.06555 & 5.06 & 6.74 & 4.71 & 2.03 \\
\hline 430 & 0.734 & 0.164 & 0.01209 & 5.21 & 4.83 & 4.17 & 0.66 \\
\hline 430 & 2.178 & 0.389 & 0.04337 & 5.21 & 6.30 & 5.04 & 1.26 \\
\hline
\end{tabular}

1 One-half peak to-peak variation from Table 2.

Lateral velocity gradients and velocities inferred from the $1 \theta$ travel time anomalies in the 2 and $4 \mathrm{~km}$ shooting radius circles assuming no vertical velocity change and using a linear gradient model for lateral velocity variations.

\begin{tabular}{|c|c|c|c|c|c|c|c|c|}
\hline \multirow{2}{*}{$\begin{array}{l}\text { Receiver } \\
\text { Depth } \\
\text { (m) }\end{array}$} & \multirow{2}{*}{$\begin{array}{c}\text { Basement } \\
\text { Range } \\
(\mathrm{km})\end{array}$} & $1 \theta$ Travel & \multirow{2}{*}{$\begin{array}{c}\text { Best fit } \\
\text { Gradient } \\
s^{-1}\end{array}$} & \multicolumn{5}{|c|}{$\begin{array}{l}\text { Velocity }(\mathrm{km} / \mathrm{s}) \\
\text { Range from borehole }(\mathrm{km})\end{array}$} \\
\hline & & (s) & & -2 & -0.6 & 0 & +0.6 & +2 \\
\hline & & 0.0382 & 1.81 & 1.30 & 3.83 & 4.92 & 6.01 & 8.54 \\
\hline & & 010 & 0.6 & & 4.56 & 4.92 & & 6.1 \\
\hline 33 & 0. & 0.02 & 1.6 & 1.65 & 3.95 & 4.93 & & 8.2 \\
\hline 33 & 2.0 & 311 & 0.7 & 3.51 & 4.50 & 4.93 & & 6.3 \\
\hline & & 0.0242 & & 2.67 & 4.32 & 5.03 & 5.74 & 7.39 \\
\hline 430 & 2.178 & 0.0867 & 0.48 & 4.07 & 4.74 & 5.03 & 5.32 & 5.99 \\
\hline
\end{tabular}


Figure 40. Comparison of velocities from tau-zeta inersion (solid line connecting squares; dashed lines are 95\% confidence limits) and inflection point method with velocities logged in Hole 418A on ODP leg 102 with borehole compensated sonic tool (Shipboard Scientific Party, 1986). Sonic $\log$ is moving average of velocities over about $7 \mathrm{~m}$.

\section{VELOCITY $(\mathrm{km} / \mathrm{s})$}

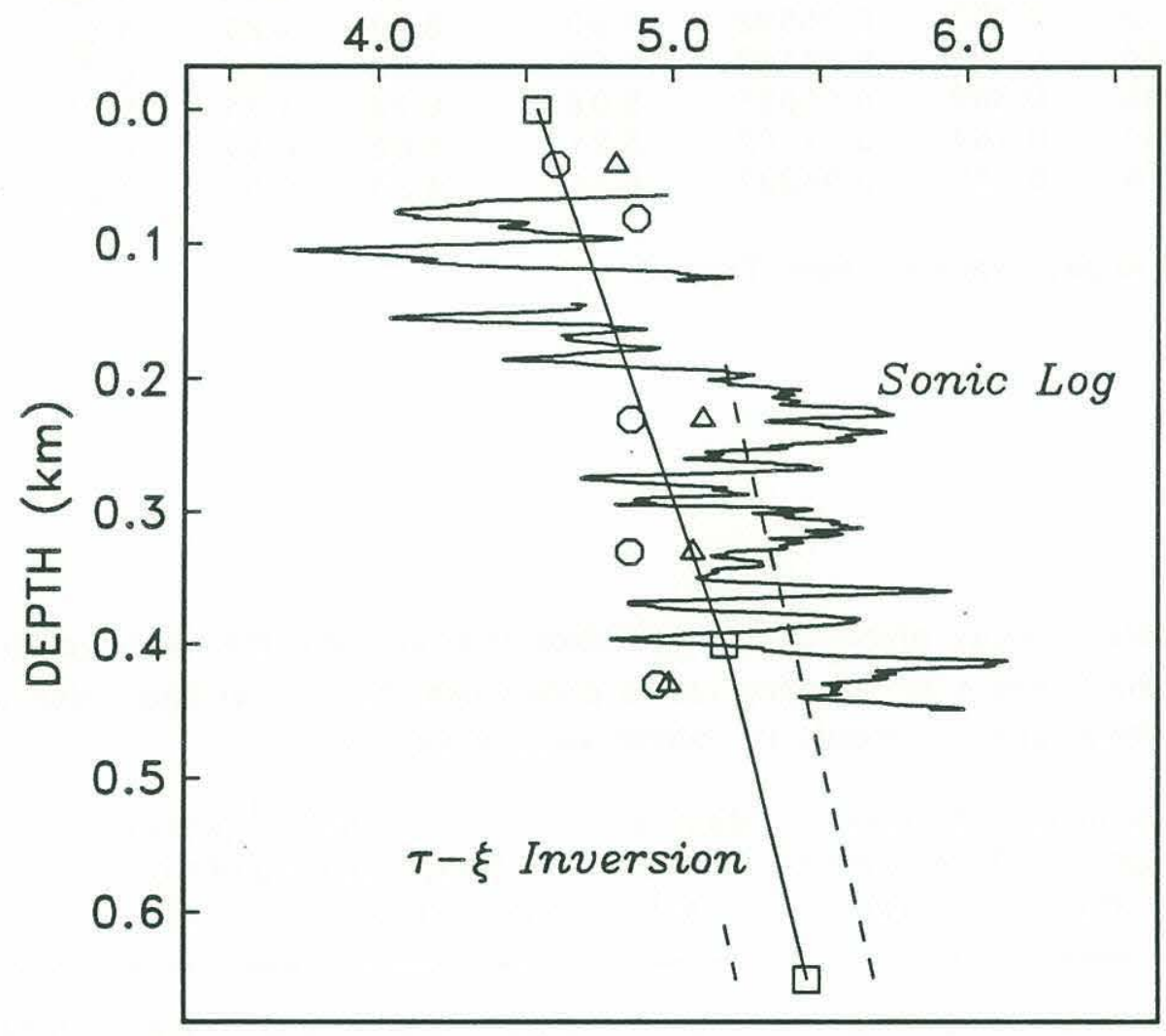


Table 15 Estimate of anisotropy that may be hidden by experimental error and lateral heterogeneities. Estimate assumes that one-half the peak-to-peak amplitude of anisotropy equals the standard error of the observed travel times.

\begin{tabular}{|c|c|c|c|c|c|c|c|}
\hline $\begin{array}{l}\text { Receiver } \\
\text { Depth } \\
(\mathrm{m})\end{array}$ & $\begin{array}{l}\text { Shooting } \\
\text { Range } \\
(\mathrm{km})\end{array}$ & $\begin{array}{l}\text { Mean } 1 \\
\text { Travel } \\
\text { Time (s) }\end{array}$ & $\begin{array}{l}\text { Standard } \\
\text { Error2 } \\
\text { (s) }\end{array}$ & $\begin{array}{c}\text { Anisotropy } \\
(\%)^{3}\end{array}$ & $\begin{array}{l}\text { Depth of } 4 \\
\text { ray turning } \\
\text { point }(\mathrm{km})\end{array}$ & $\begin{array}{l}\text { Velocity } 5 \\
\text { at turning } \\
\text { point }(\mathrm{km} / \mathrm{s})\end{array}$ & $\begin{array}{l}\text { Velocity } \\
\text { Anisotropy } \\
(\mathrm{km} / \mathrm{s})^{6}\end{array}$ \\
\hline 230 & 2 & 0.133 & $8.253 E-3$ & \pm 6.2 & $<0.4$ & 4.90 & \pm 0.30 \\
\hline 330 & & 0.139 & $7.444 \mathrm{E}-3$ & \pm 5.4 & & 5.06 & \pm 0.27 \\
\hline 430 & & 0.164 & $7.283 E-3$ & \pm 4.4 & & 5.21 & \pm 0.22 \\
\hline 230 & 4 & 0.377 & $2.765 E-2$ & \pm 7.3 & 0.27 & 4.96 & \pm 0.36 \\
\hline 330 & & 0.369 & $2.198 \mathrm{E}-2$ & \pm 6.0 & 0.35 & 5.09 & \pm 0.30 \\
\hline 430 & & 0.389 & $3.094 \mathrm{E}-2$ & \pm 8.0 & 0.44 & 5.22 & \pm 0.42 \\
\hline 81 & 6 & 0.874 & $3.556 \mathrm{E}-2$ & \pm 4.1 & 0.55 & 5.35 & \pm 0.22 \\
\hline 230 & & 0.862 & $2.781 \mathrm{E}-2$ & \pm 3.2 & 0.63 & 5.44 & \pm 0.17 \\
\hline 330 & & 0.856 & $3.476 \mathrm{E}-2$ & \pm 4.1 & 0.68 & 5.50 & \pm 0.22 \\
\hline 430 & & 0.815 & $4.016 \mathrm{E}-2$ & \pm 4.9 & 0.75 & 5.59 & \pm 0.27 \\
\hline 230 & 8 & 1.368 & $4.553 \mathrm{E}-2$ & \pm 3.3 & 1.4 & 6.24 & \pm 0.20 \\
\hline 330 & & 1.359 & $3.651 \mathrm{E}-2$ & \pm 2.7 & 1.5 & 6.40 & \pm 0.17 \\
\hline 430 & & 1.263 & $3.268 \mathrm{E}-2$ & \pm 2.6 & 1.6 & 6.56 & \pm 0.17 \\
\hline
\end{tabular}

1. From Table 2.

2. For circles shot at 2 and $4 \mathrm{~km}$ radius, standard error about $1 \theta$ variation. For 6 and $8 \mathrm{~km}$ circles, standard error about mean.

3. Standard error times 100 divided by mean travel time.

4. For 2 circles, rays turn above receivers. For 4,6 and $8 \mathrm{~km}$ circles, depths are from ray tracing through velocity gradients given by $\tau-\zeta$ inversion. Deepest gradient (between 1.38 $\mathrm{km}$ and $1.76 \mathrm{~km}$ ) was extended to $2 \mathrm{~km}$ depth to get ray depths for $8 \mathrm{~km}$ circles.

5. Velocities found by interpolation between $\tau-\zeta$ inversion velocities.

6. Product of percentage of anisotropy/100 and velocity at depth where rays turn. 
Figure 41. Noise spectra from Stephen and Swift (1986).

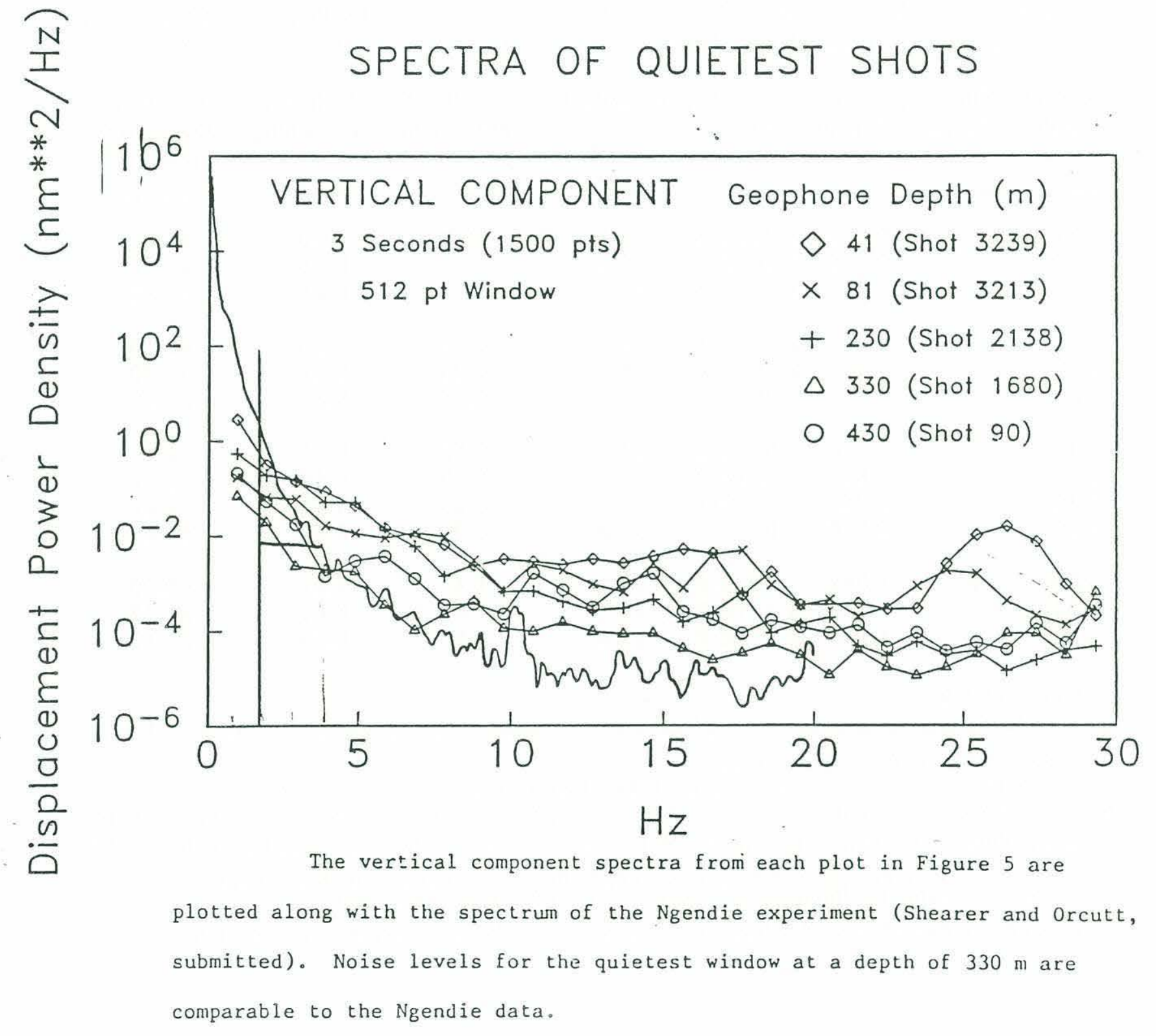


Preliminary power distribution maps have been compiled for 418A. We computed total power in a 2 -second window after the $\mathrm{P}$-wave arrival for explosive and airgun data at each of 5 seismometer depths (Figure 42 top; no airgun data at $41 \mathrm{~m}$ ). We computed means in $1.0 \mathrm{~km}$ sliding windows with $0.2 \mathrm{~km}$ overlap and corrected each shot for the mean (Figure 42 bottom). Figure 43 shows plots of five seismometer depth-source combinations at $2 \mathrm{~dB}$ contour intervals. Variations in residual power are due, presumably, to small scale heterogeneities, azimuthal variations, and error. Other receiver-source pairs could not be contoured because of too little data or because of variations during shooting in source power. The only consistent pattern is relatively low power values at most ranges in the azimuthal window $\sim 250^{\circ}-360^{\circ}$ from Hole $418 \mathrm{~A}$. Azimuths of $\sim 40^{\circ}-80^{\circ}$ and $\sim 180^{\circ}-220^{\circ}$ tend to have higher values than elsewhere.

\section{DATA STORED IN NATIONAL GEOPHYSICAL DATA CENTER}

\section{Underway Geophysics}

We searched the National Geophysical Data Center (NGDC) files in the region $24^{\circ}$ to $26^{\circ} \mathrm{N}$ latitude and $67^{\circ}$ to $69^{\circ} \mathrm{W}$ longitude for bathymetry, seismic, magnetic and gravity data. The search found a total of 32 cruises that had collected at least one of these types of data within the region: 29-bathymetry, 20-seismic, 18-magnetics, and 12-gravity. Two significant omissions in the NGDC data set are the LYNCH 702 cruise in Fall, 1976, and

the FRED MOORE cruise in Spring, 1985. Both ships collected bathymetry and seismics, whereas only the LYNCH collected magnetics. Table 2 lists all cruises.

Based on tracklines we identified cruises which passed within $15 \mathrm{~km}$ of Sites 417 and 418 (Table 16). This subset contains all the cruises which obtained data in the immediate vicinity of the boreholes. Figure 44 shows cruise tracks obtained from various sources.

A variety of methods have been used to navigate the ship tracks listed in Table 2. Some methods have large errors. We used bathymetry to integrate cruise tracks, but in 
Figure 42. Range plots of total power (sum of vertical and two orthogandi horizontal components) for two seconds after the $\mathrm{P}$ arrival. Top panel shows uncorrected data. Source type is given in upper left and receiver depth in upper right. Solid line connects averages in one kilometer window moved with $0.2 \mathrm{~km}$ overlap. Bottom panel shows data corrcted for moving average.
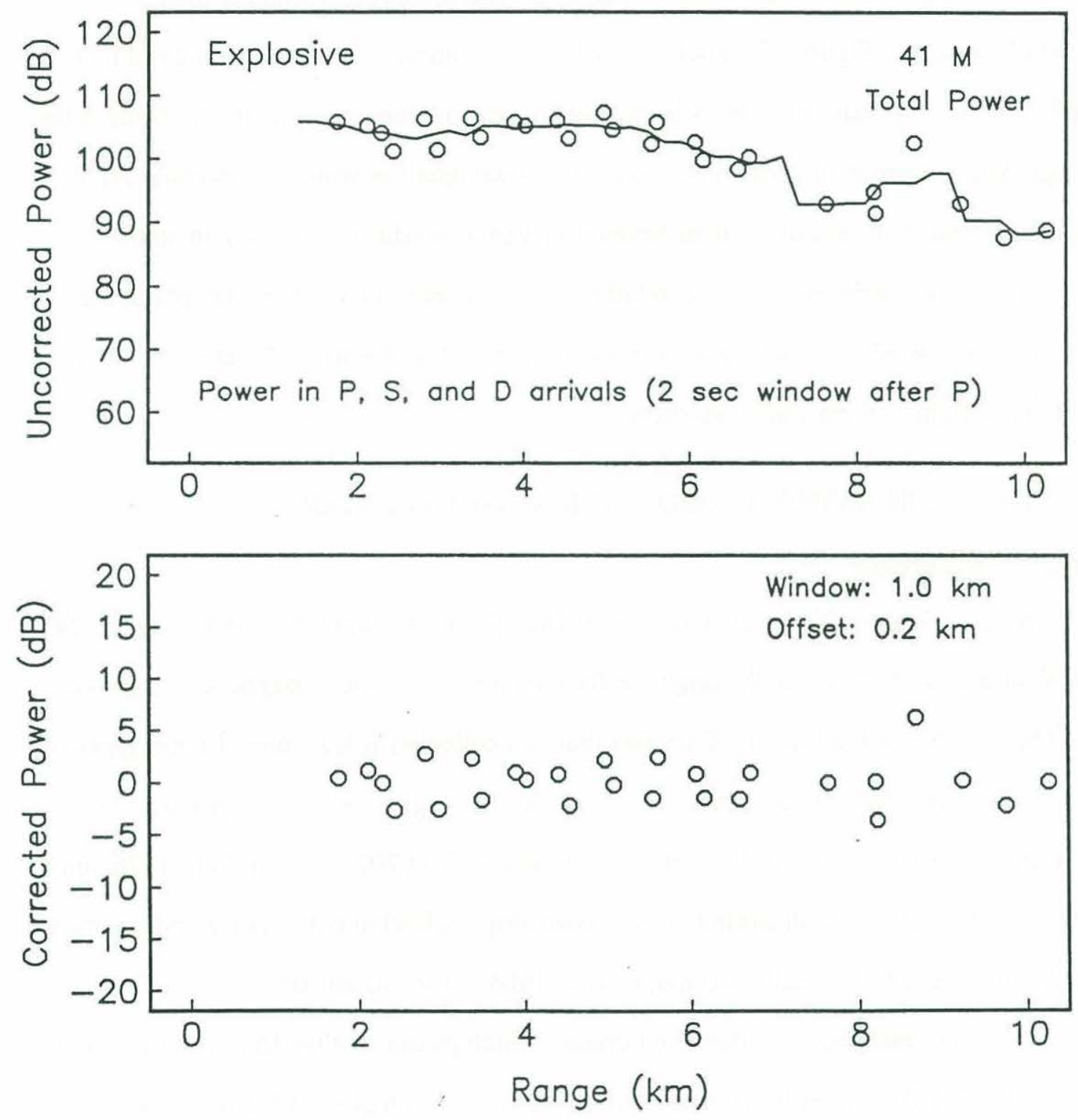
Figure $42 \mathrm{~b}$.
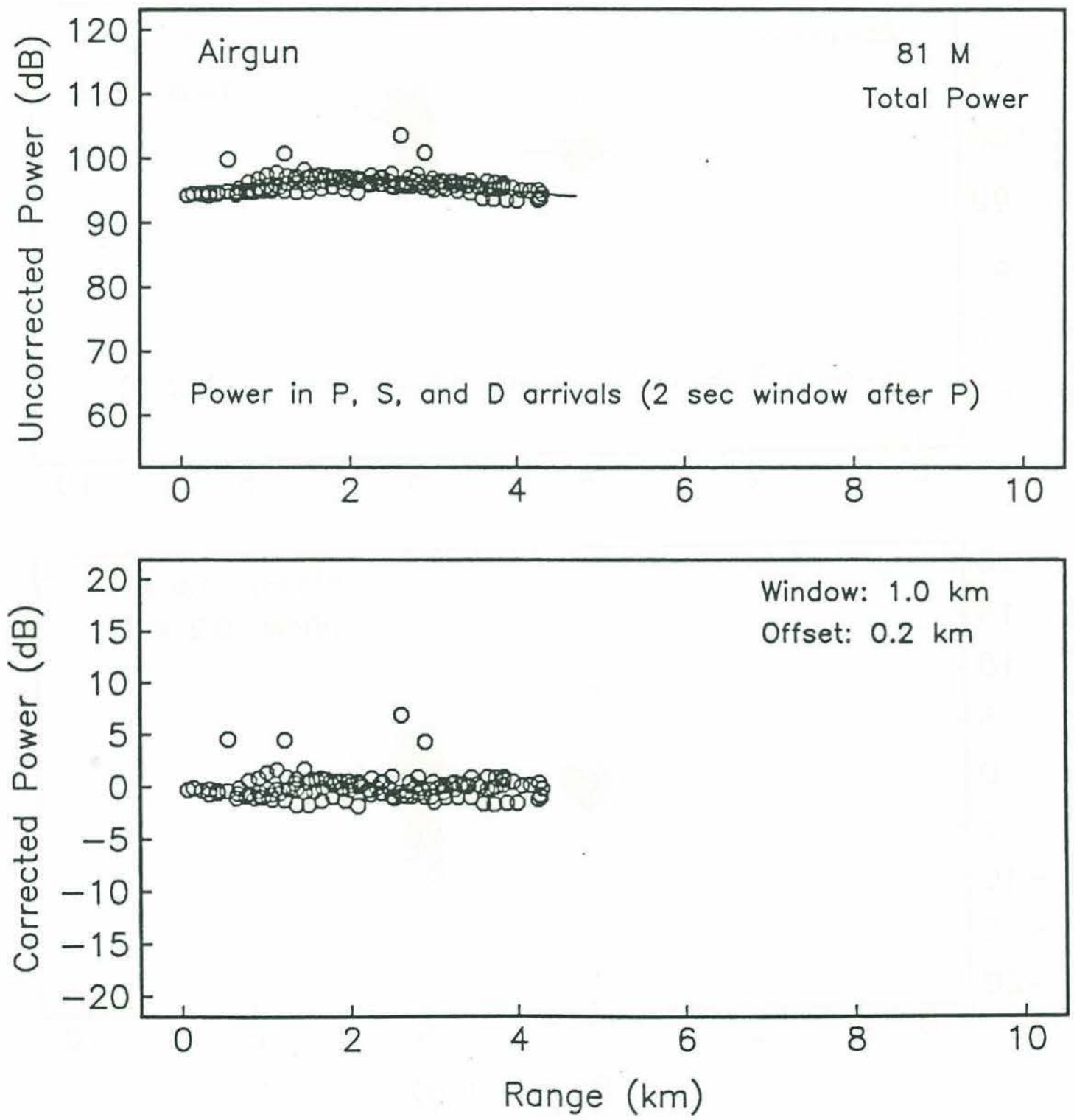
Figure 42c。
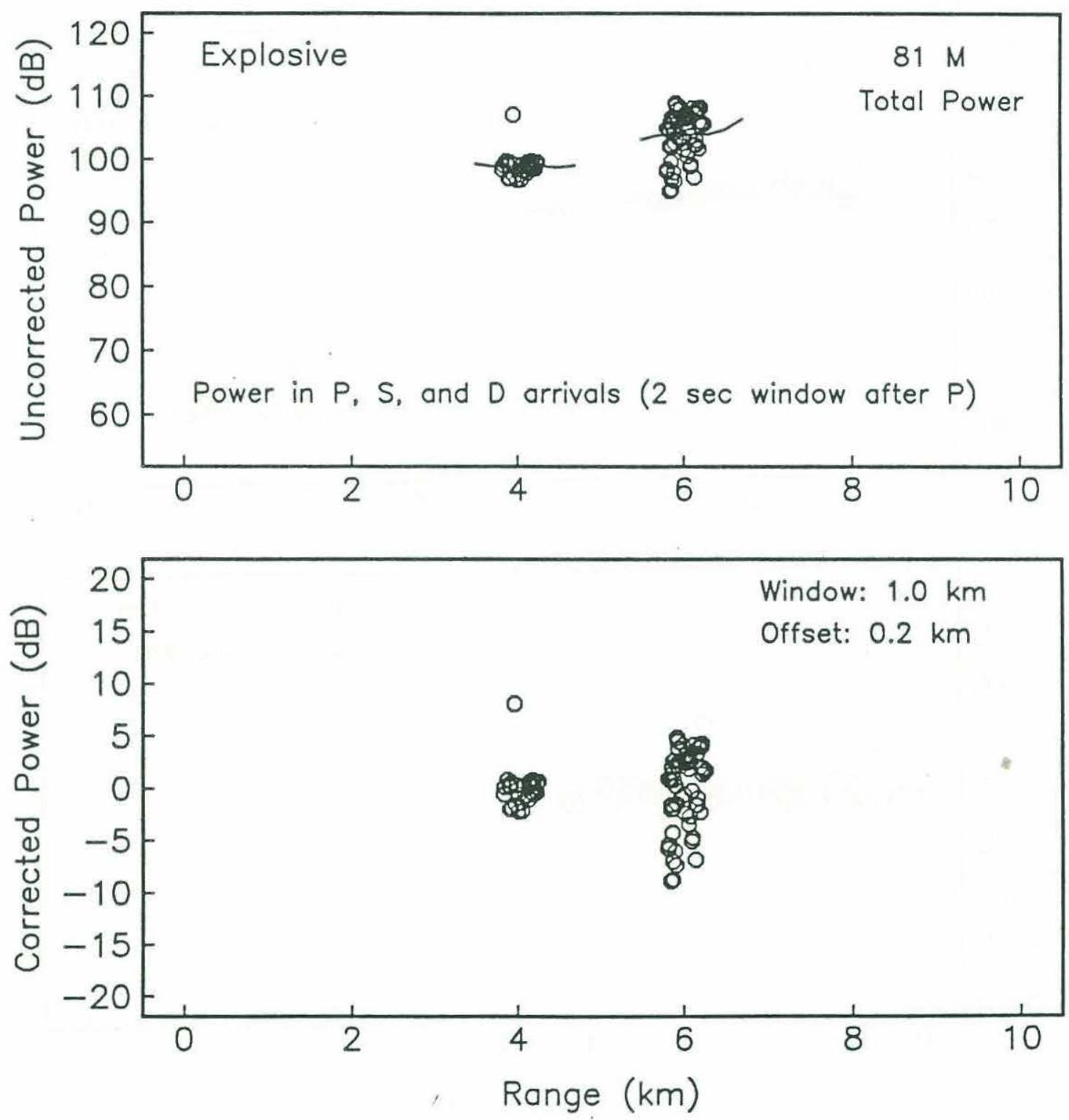

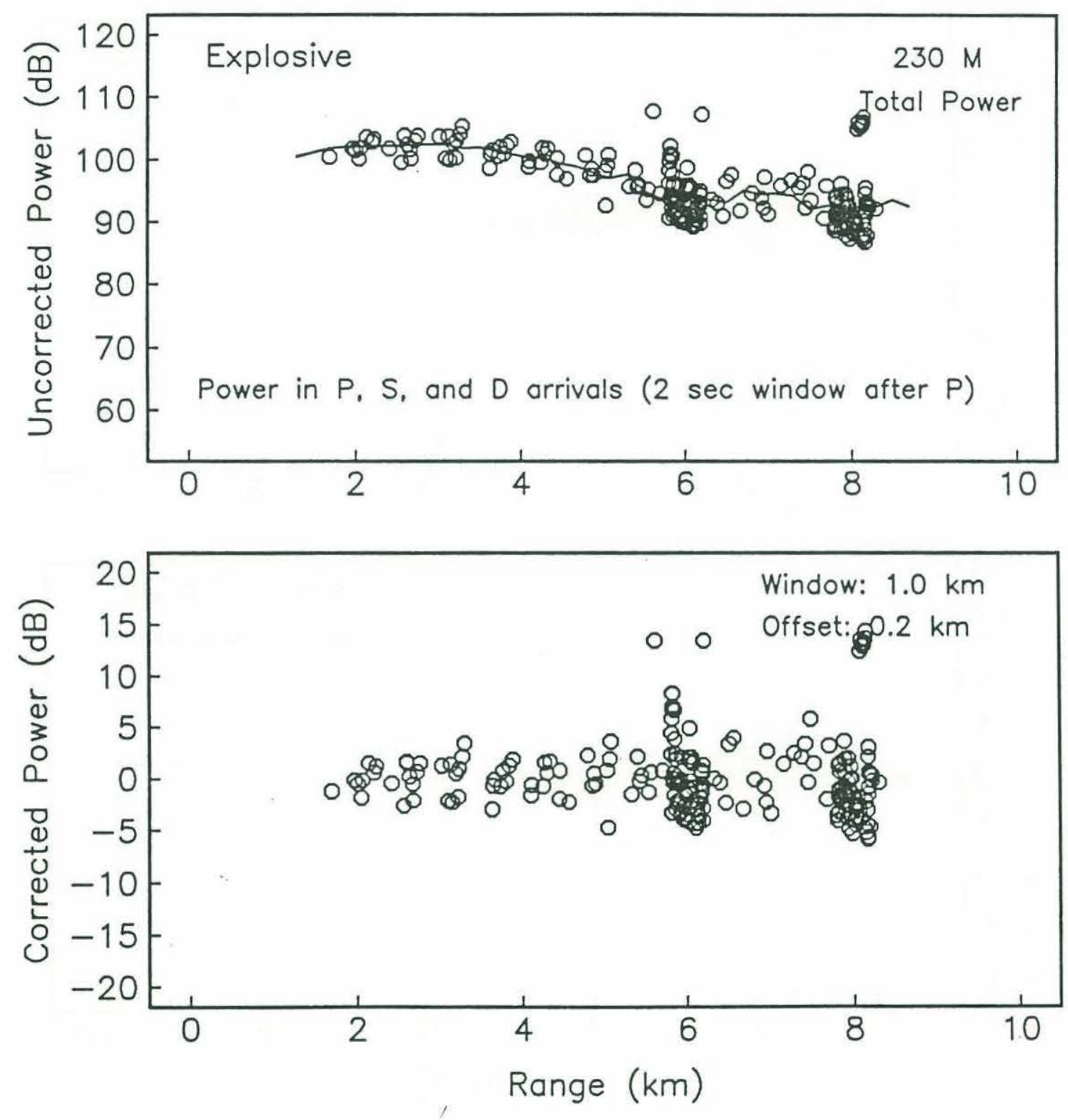
Figure $42 \mathrm{e}$.
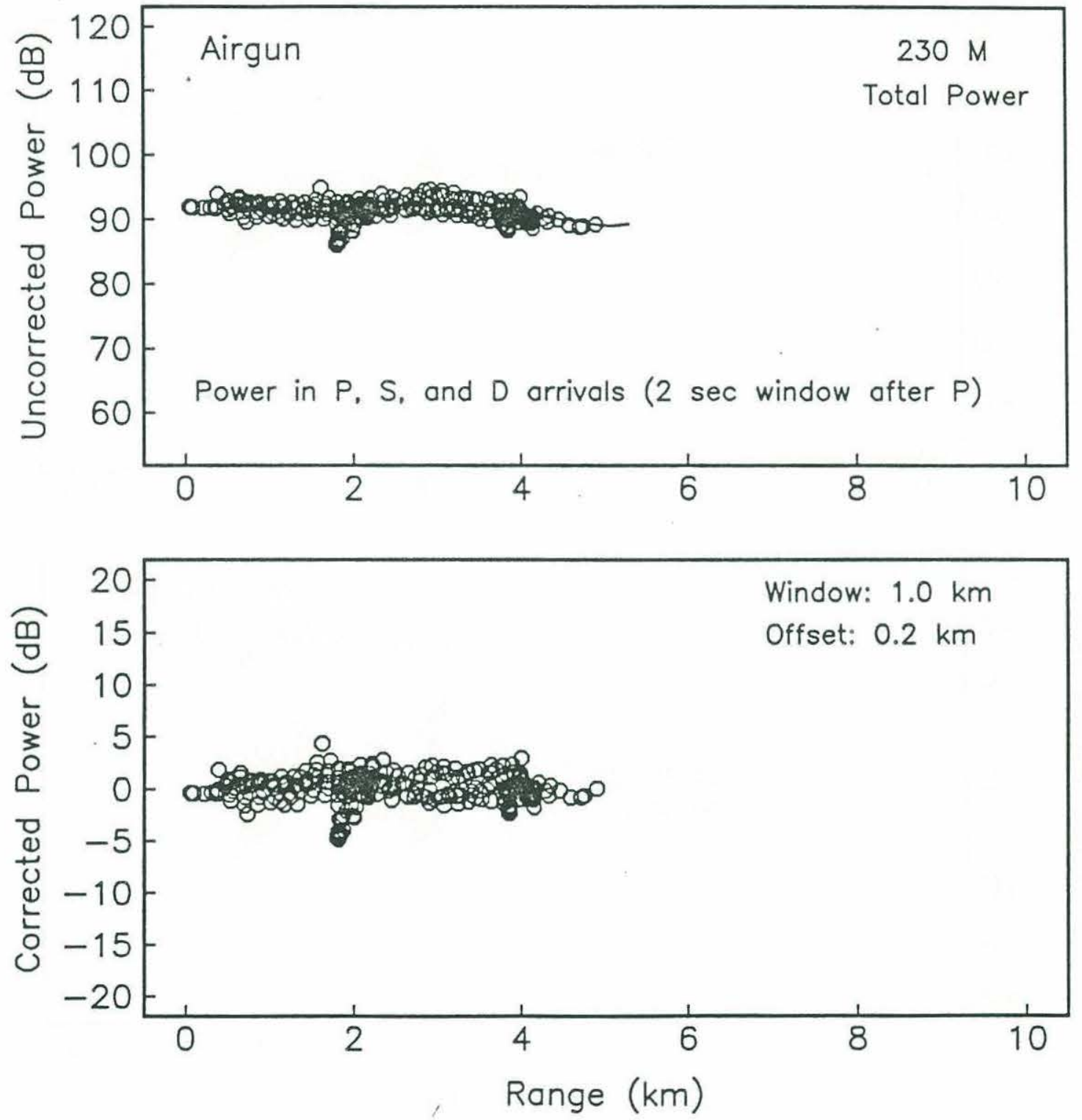
Figure $42 f$.
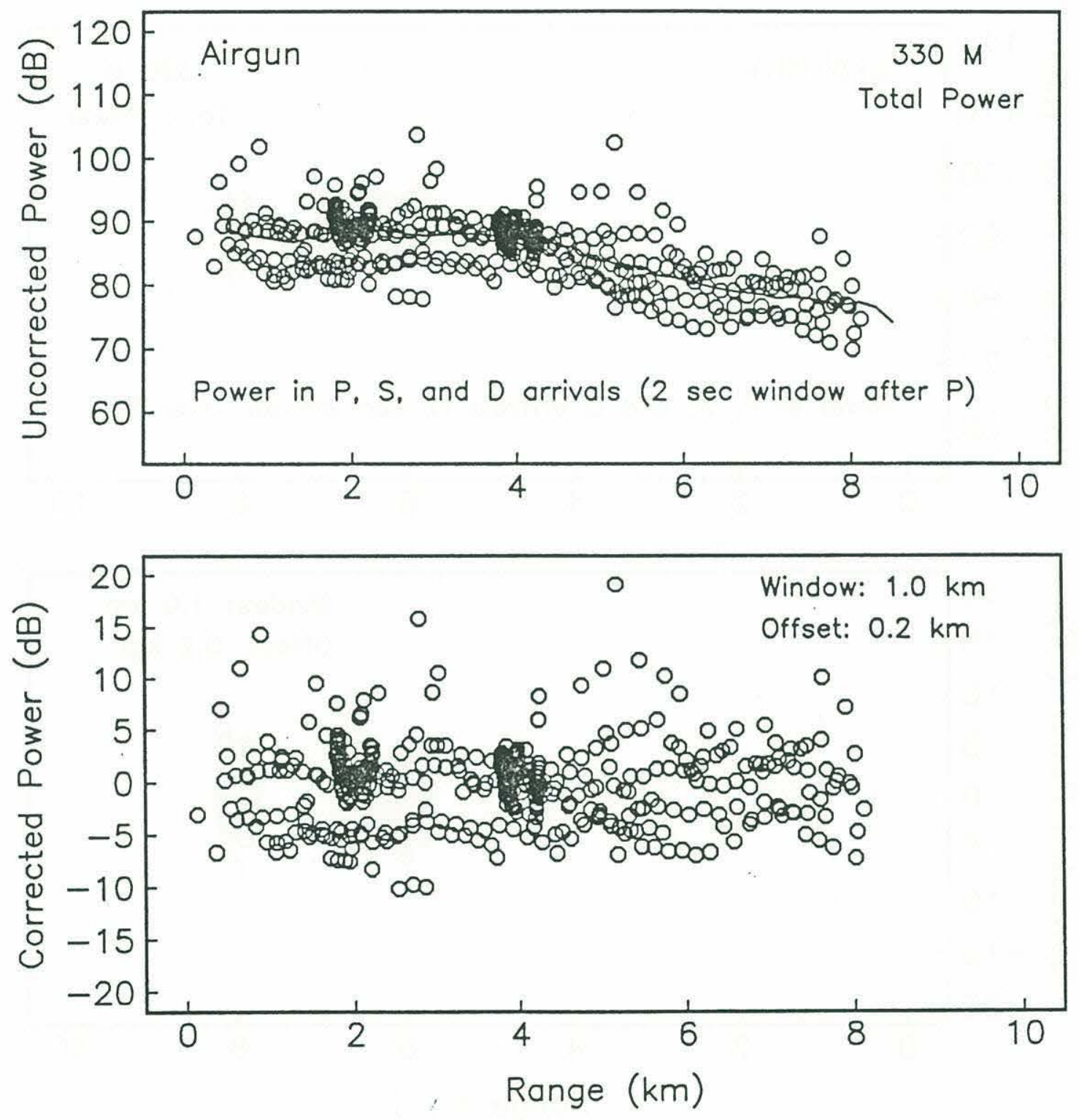

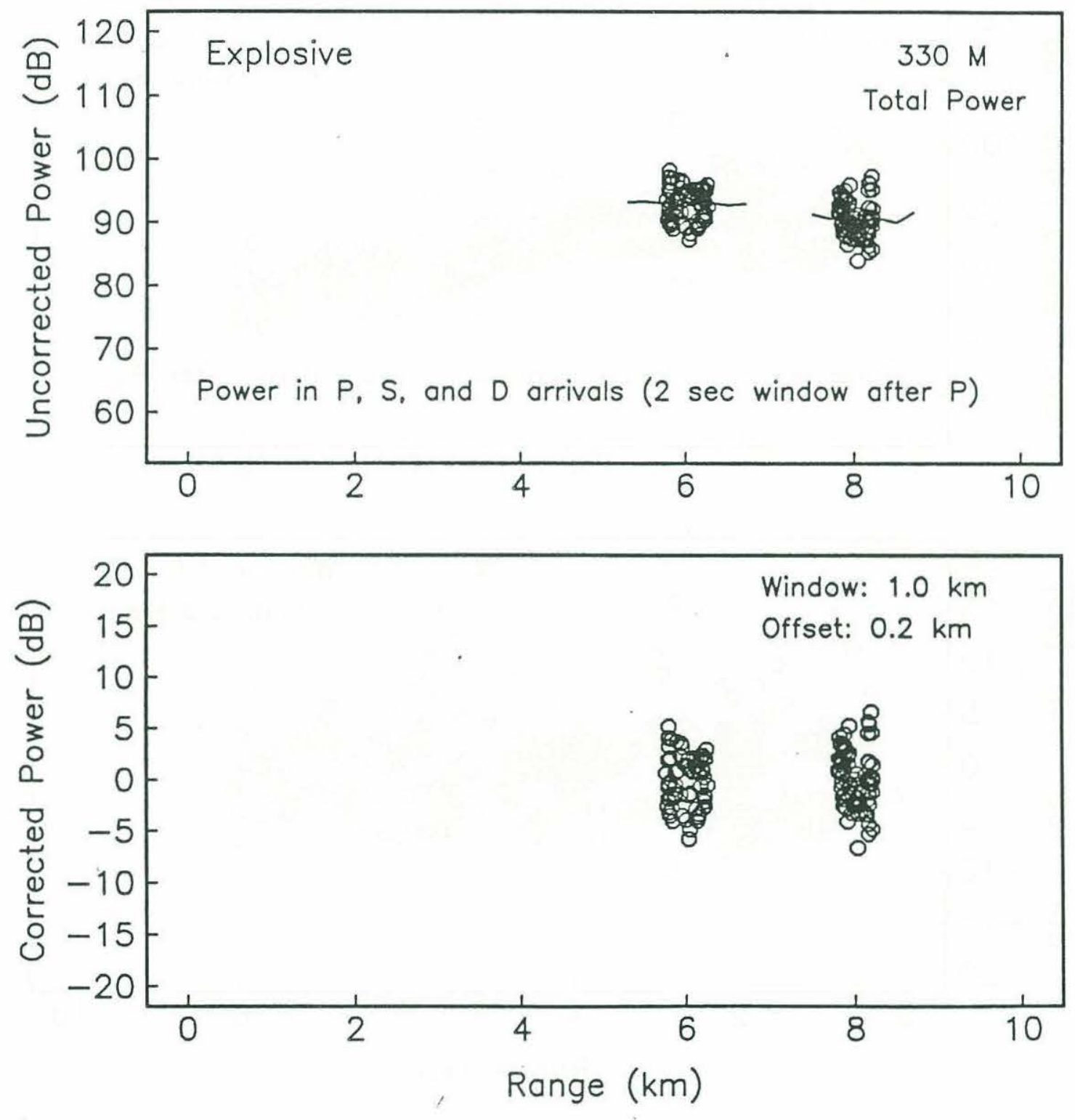

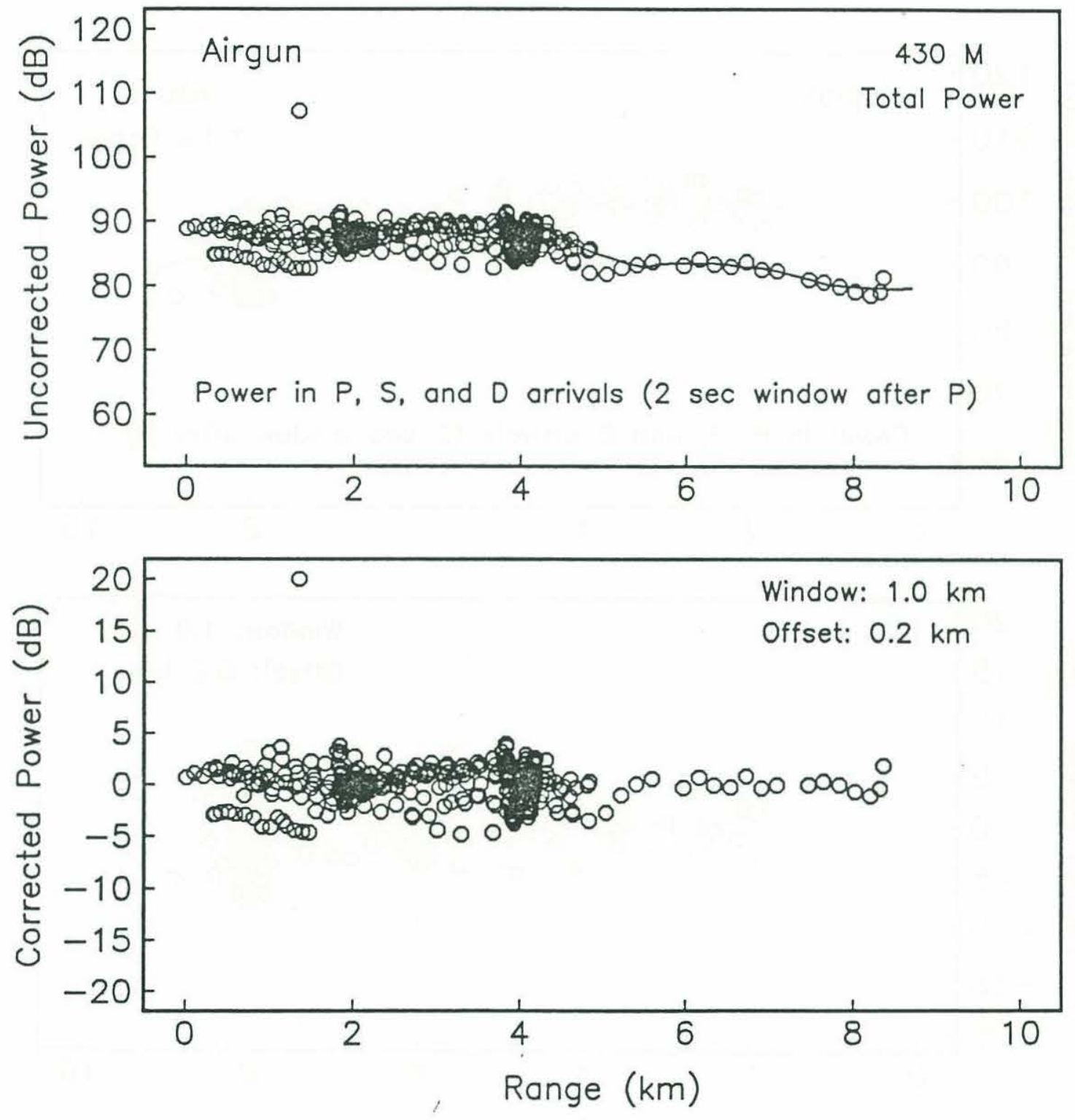

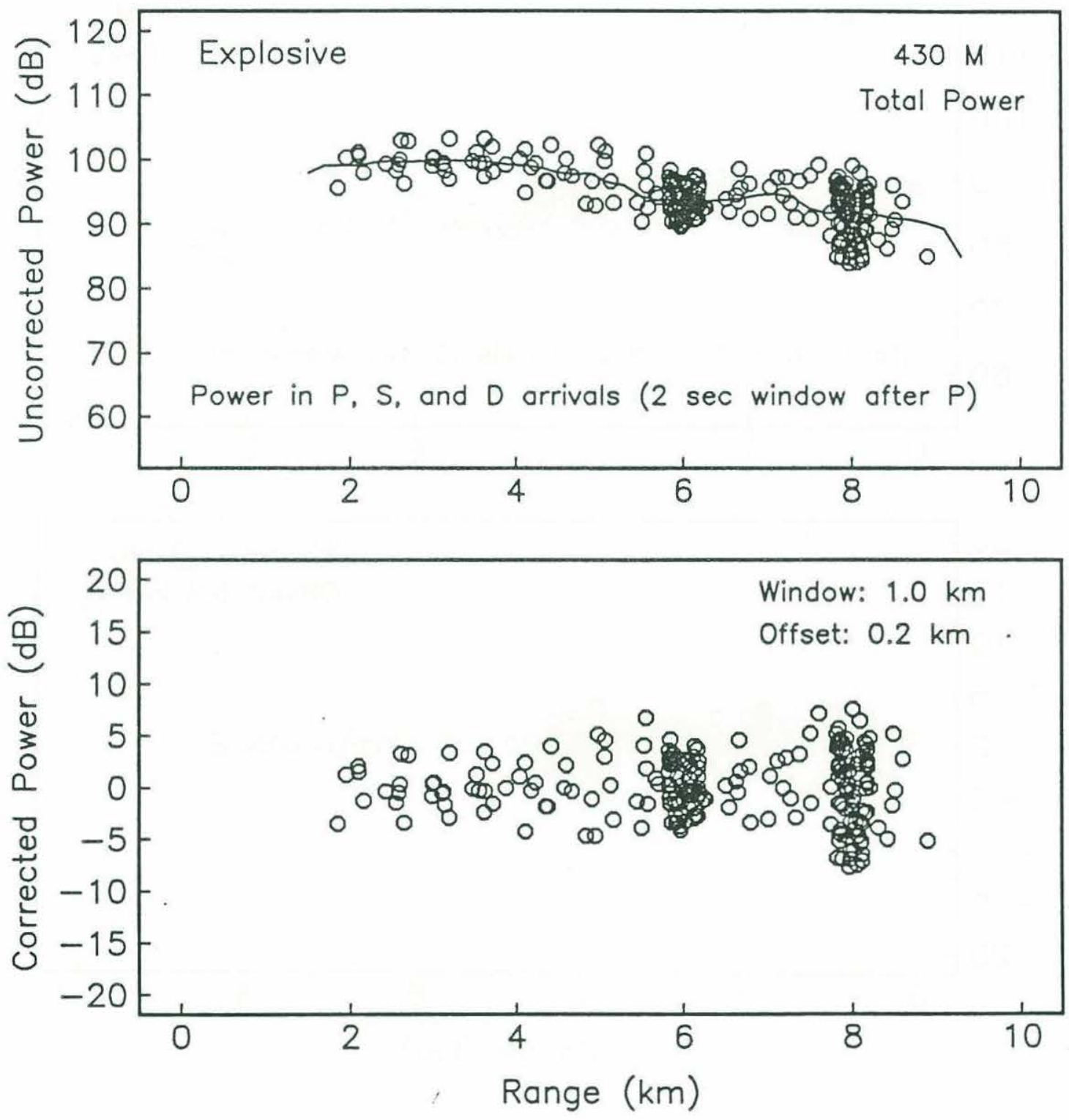
Reduction

- nept 5 fig

otal power received during shooting of the oblique seismic xperiment at Hole 418A on ODP Leg 102. Data corrected for at same oving average computed over a $1 \mathrm{~km}$ window (see Figure 42).

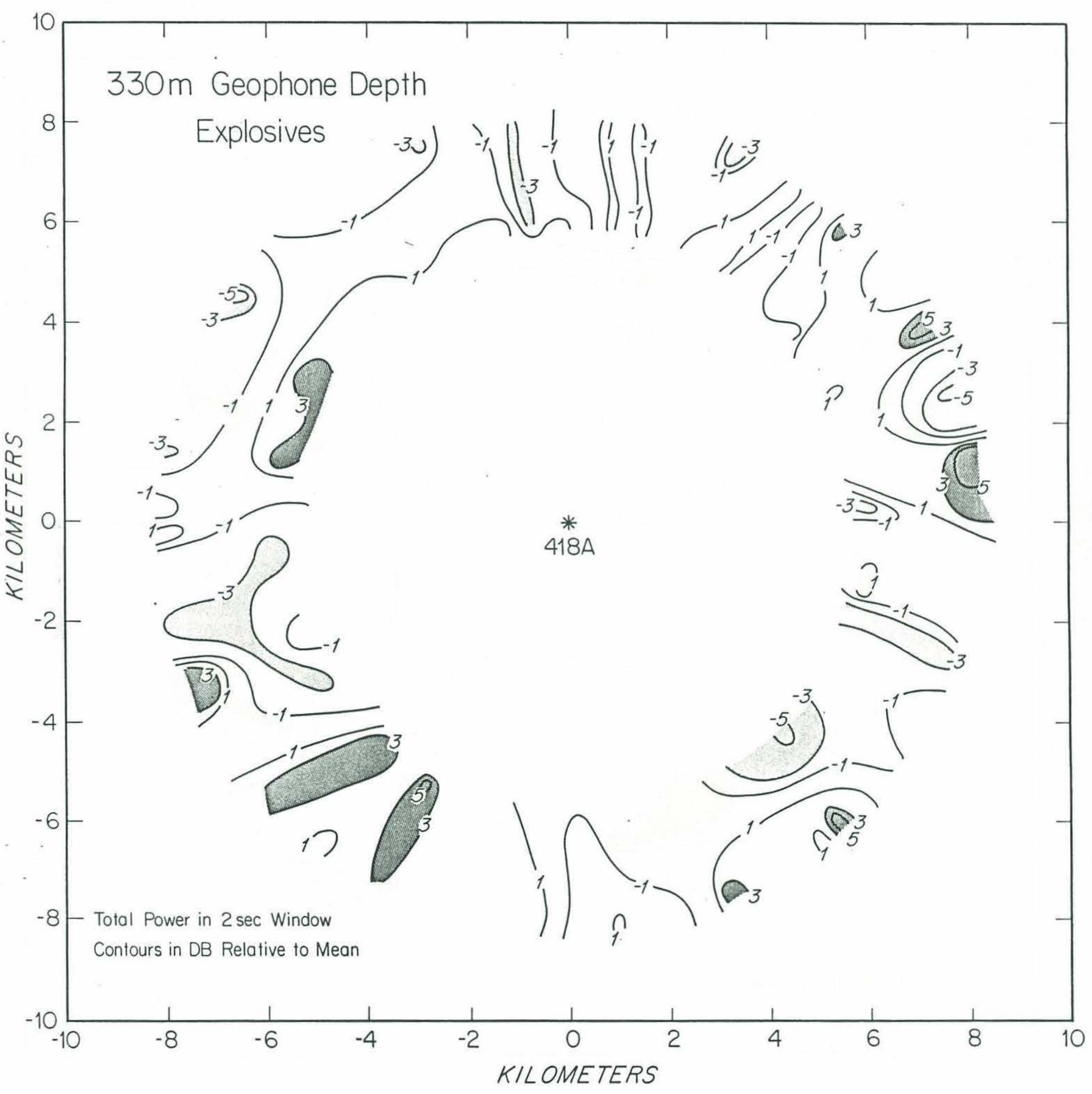


Figure $43 \mathrm{~b}$.

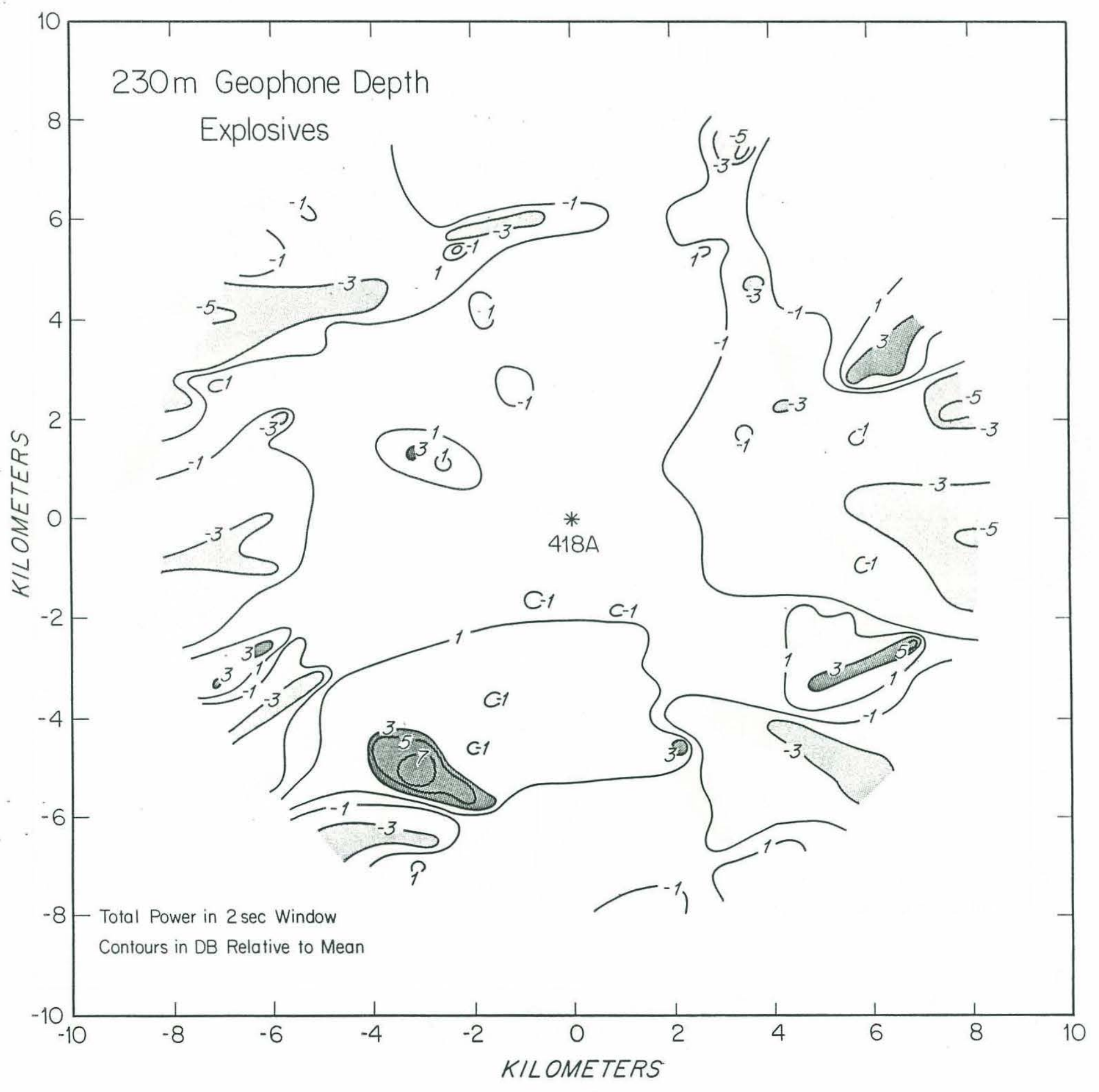


Figure $43 c$.

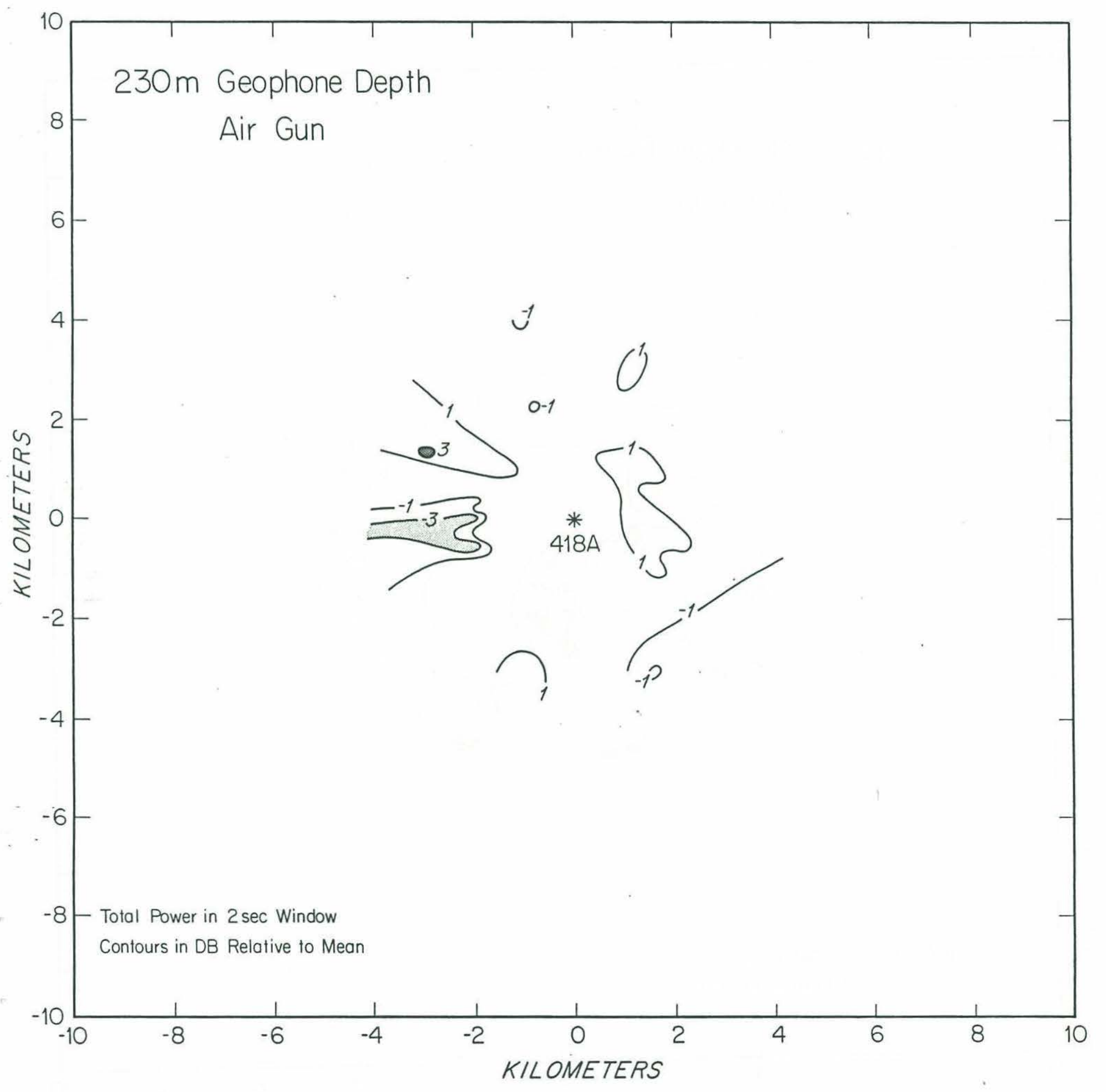




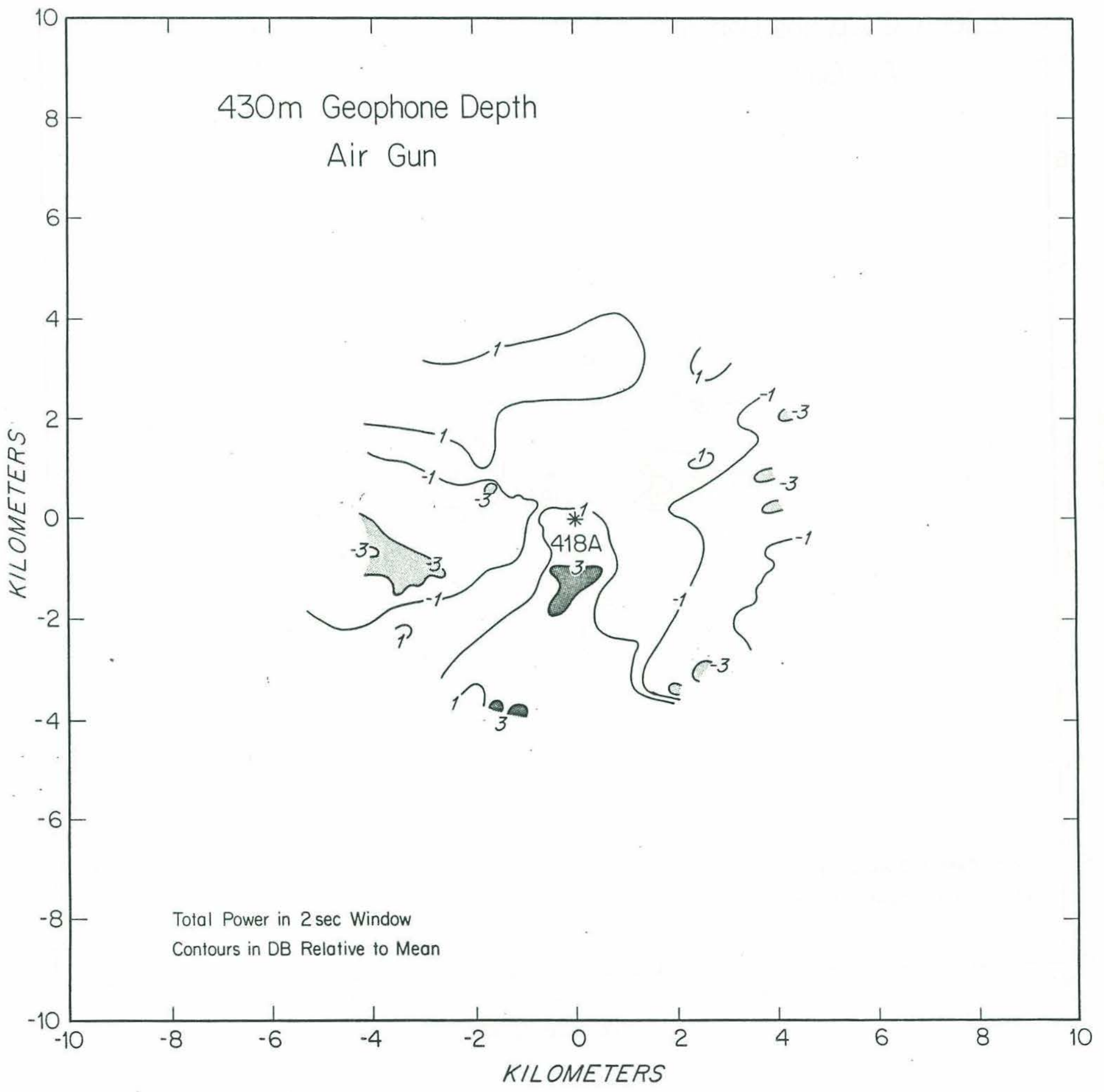


Figure $43 \mathrm{e}$.

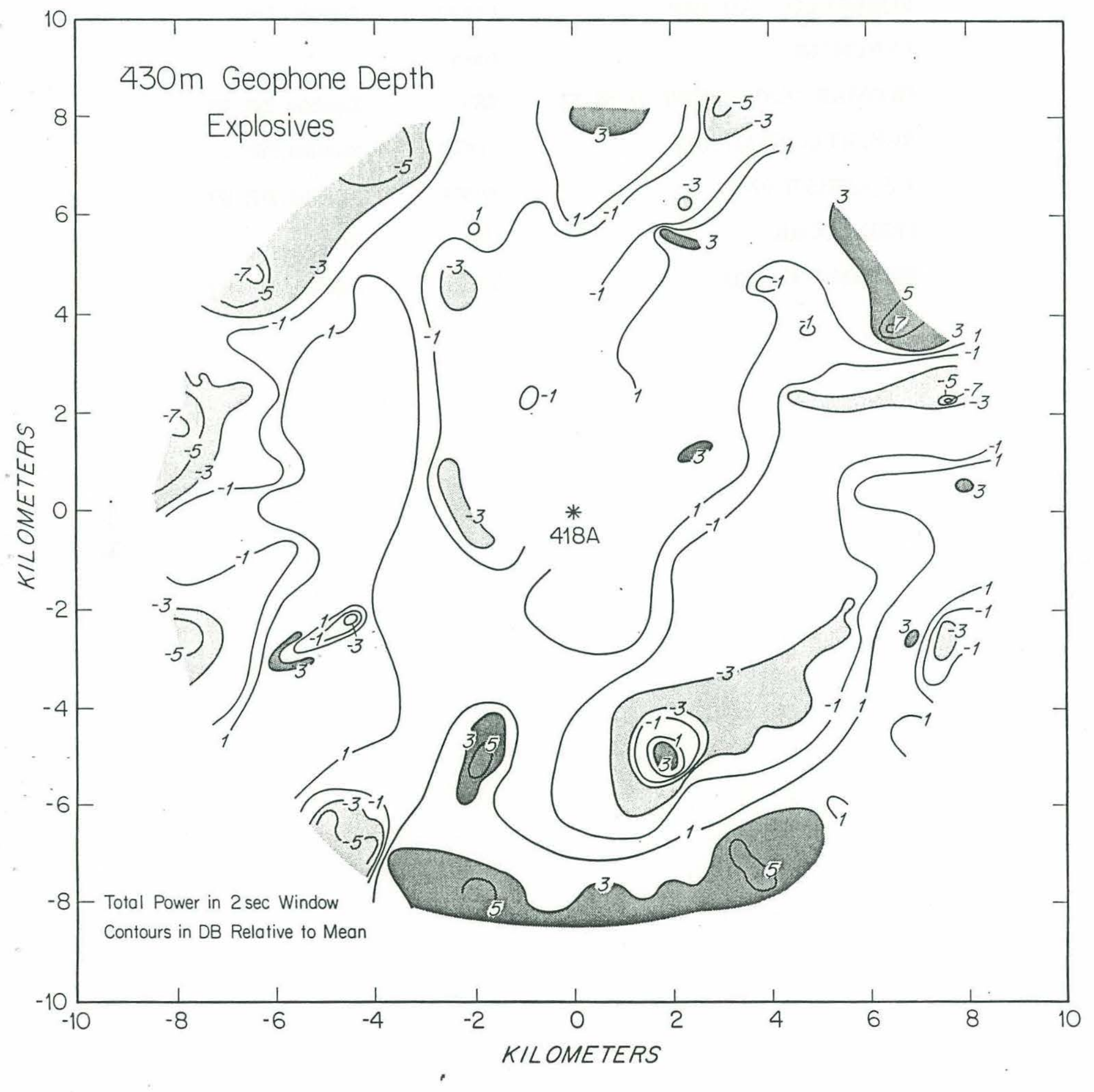


TABLE 16 :LIST OF SCIENTIFIC CRUISES WHICH COLLECTED DATA WITHIN $15 \mathrm{KM}$ OF SITES 417 and 413

\begin{tabular}{|c|c|c|}
\hline$\underline{\text { Cruise }}$ & Institution & Navigation \\
\hline VEMA 1802 & LDGO & Celestial? \\
\hline ROBERT CONRAD 1903 & LDGO & Satellite, DR \\
\hline LYNCH 702 & Navy & $"$ \\
\hline GLOMAR CHALLENGER $51,52,53$ & SIO & Satellite, DR, BT \\
\hline ROBERT CONRAD 2012 & LDGO & Satellite, DR \\
\hline ATLANTIS II 97-2 & WHOI & Satellite, DR, BT \\
\hline FRED MOORE & UT & Radar \\
\hline SEDCO/BP 471102 & TAMU & Satellite, DR, BT \\
\hline
\end{tabular}




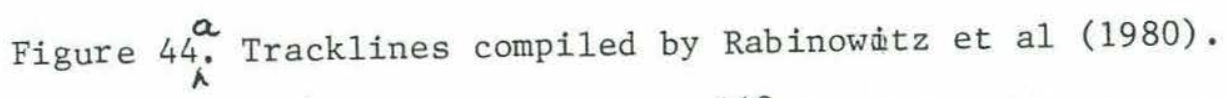

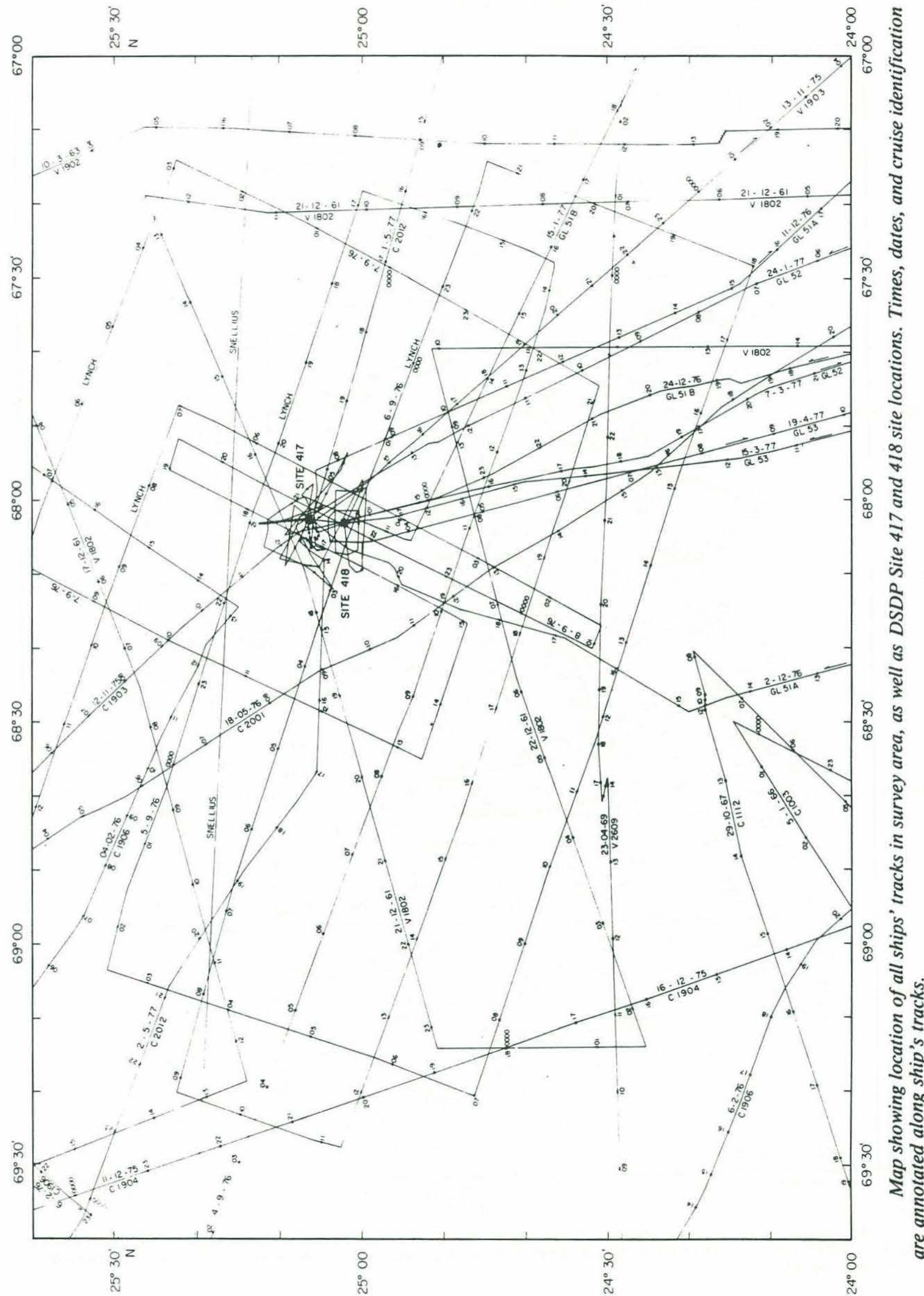


Figure $44^{b}$. Trackline of FRED MOORE during seismic reflection survey of Hole $418 \mathrm{~A}$ from Auroux and Stephen (1986).

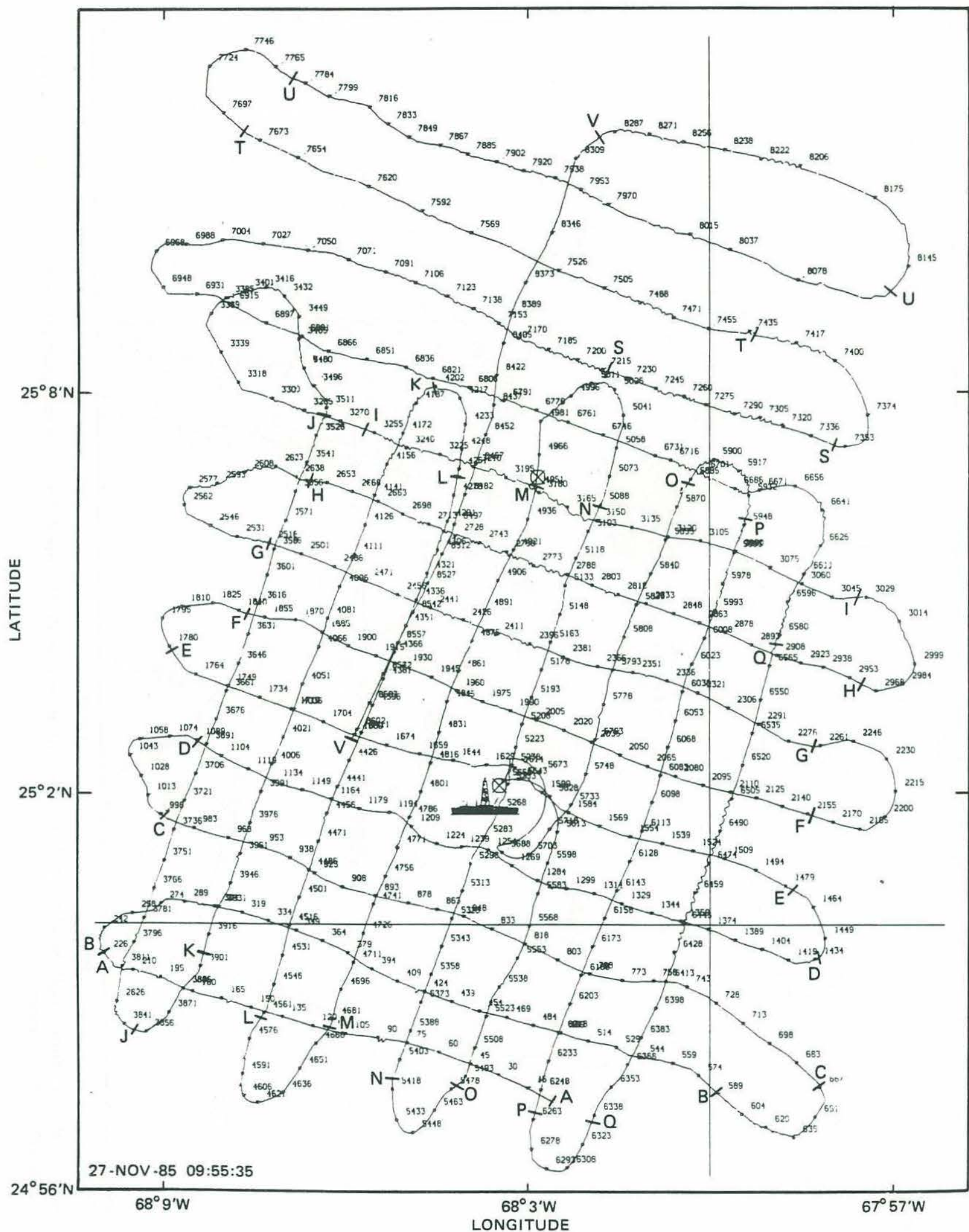

Map location of the site-survey seismic lines collected by the R/V Fred $H$. Moore. The numbers refer to the seismic-line shot points. Letters delimit portions of lines along which data were collected; e.g., data were collected between $C$ and $C$ but not between $B$ and $C$ or between $C$ and $D$. 
Figure 44c. Shot point locations during shooting of the Oblique Sei experiment at depth was recorded at each shot location.

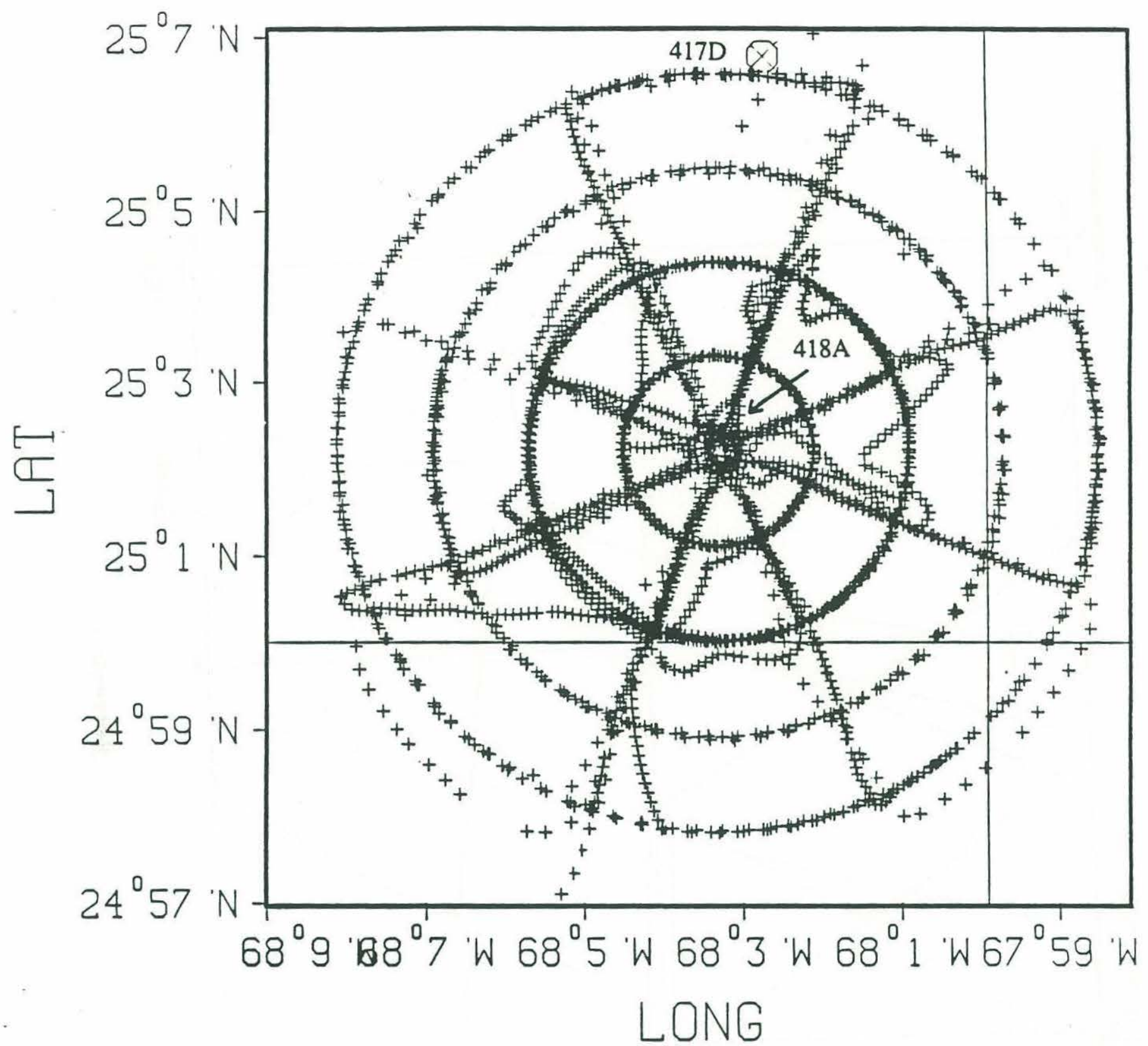


Figure 44d. Tracklines by WHOI vessels archived in the NGDC.

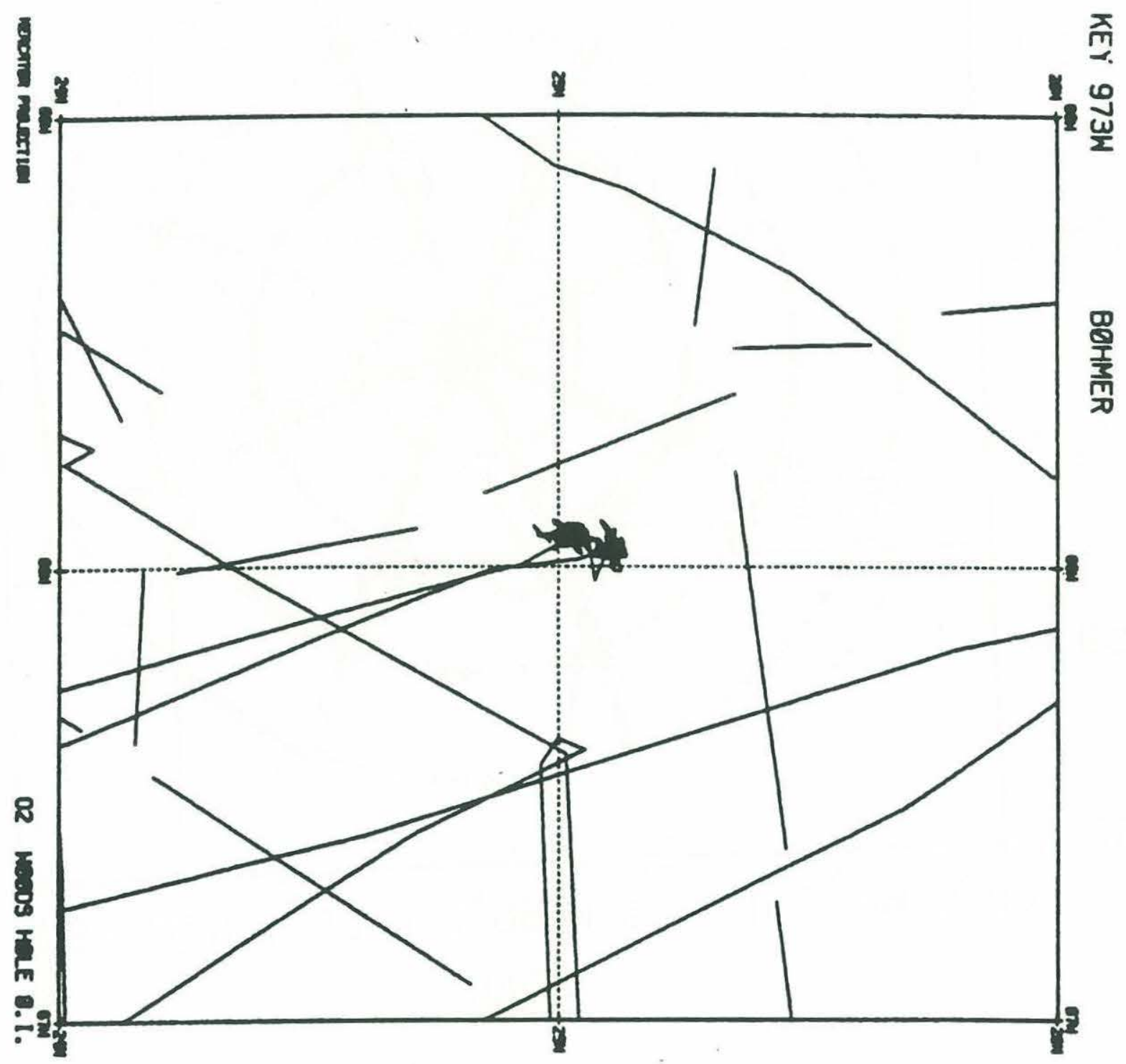


Figure 44e. Tracklines of LDGO vessels archived in the NGDC.

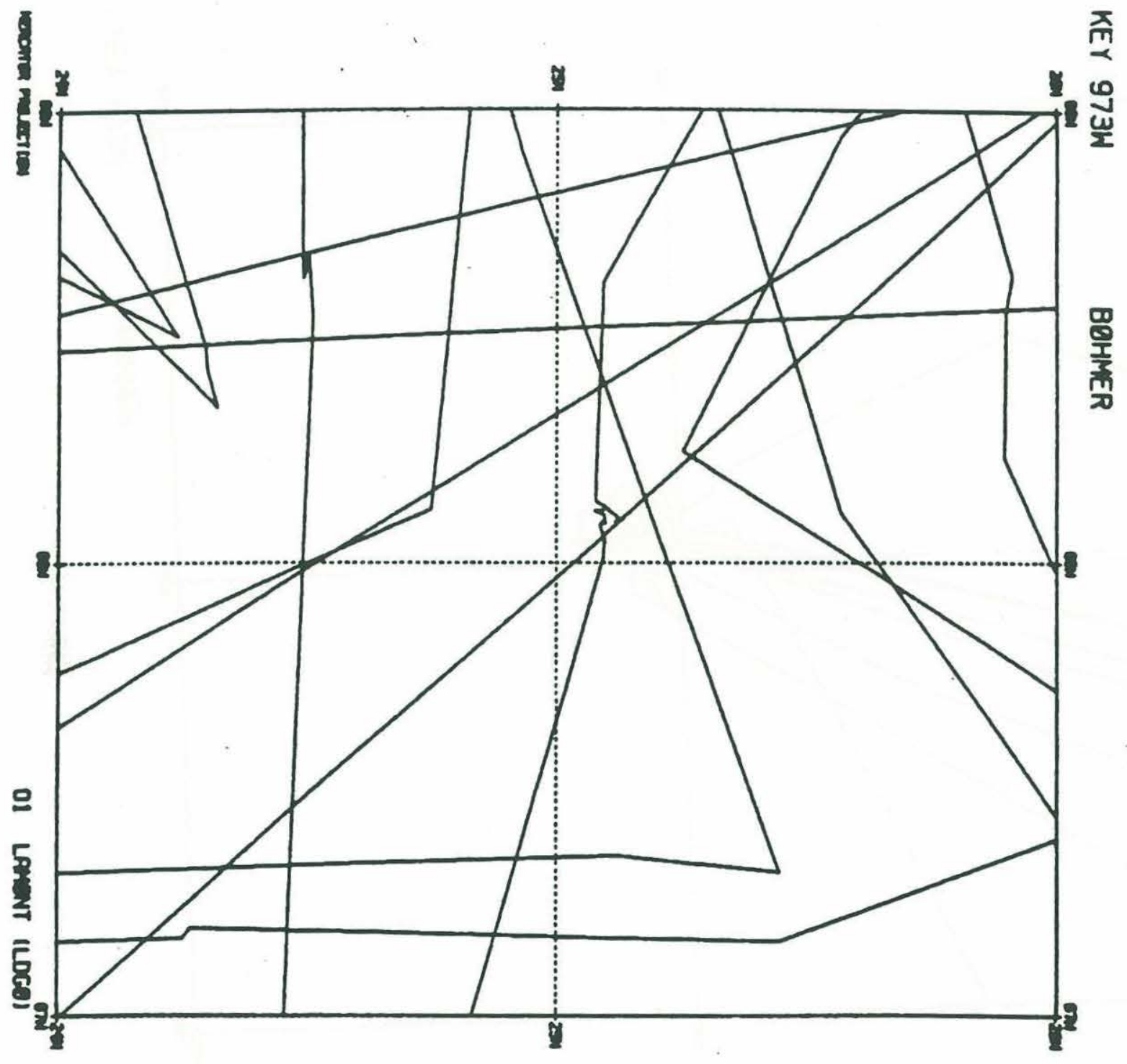


Figure 44f. Tracklines by SIO vessels (GLOMAR CHALLENGER) archived in the NGDC .

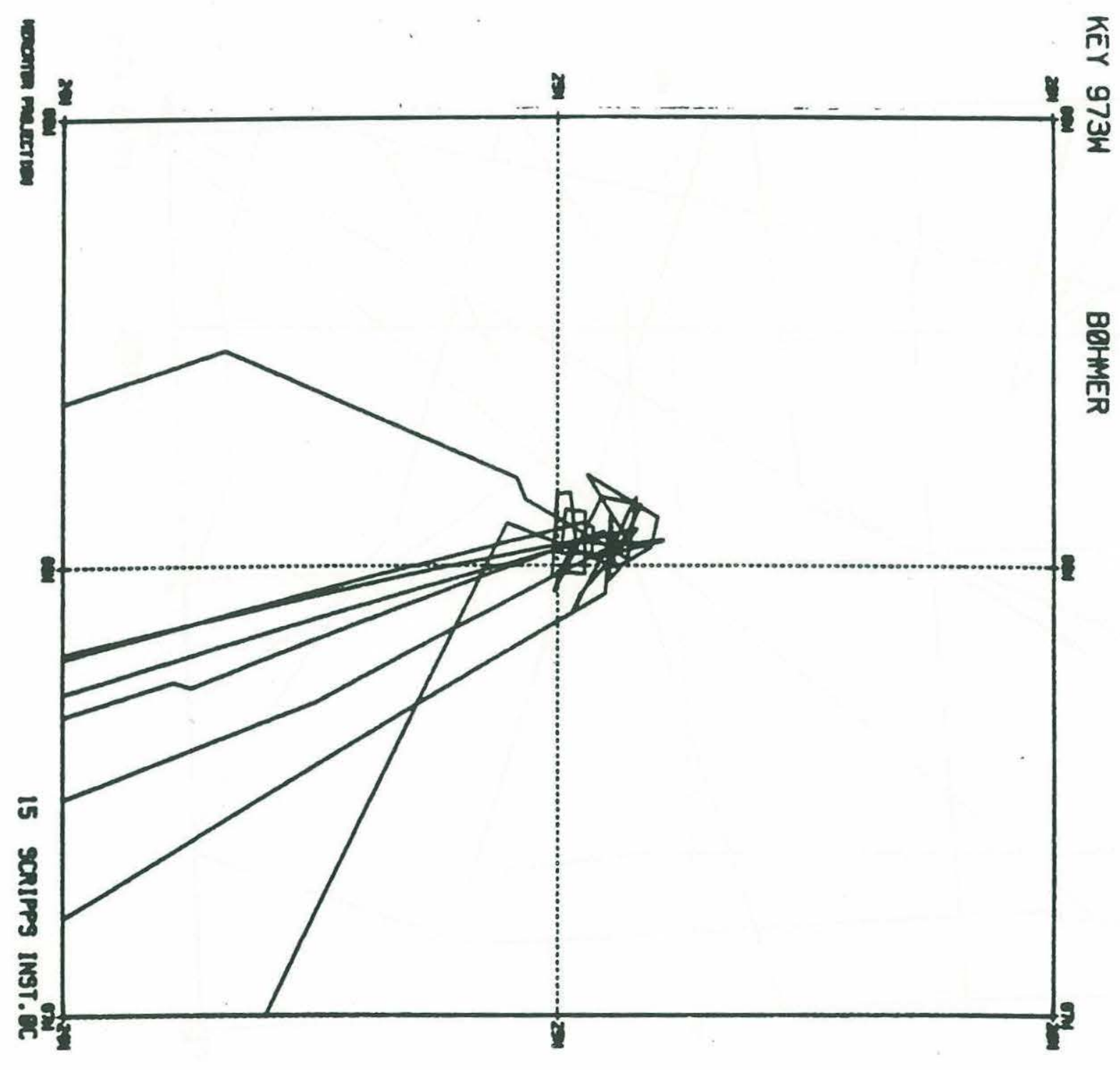


125

Figure 44g. Tracklines by NOAA vessels archived in the NGDC.

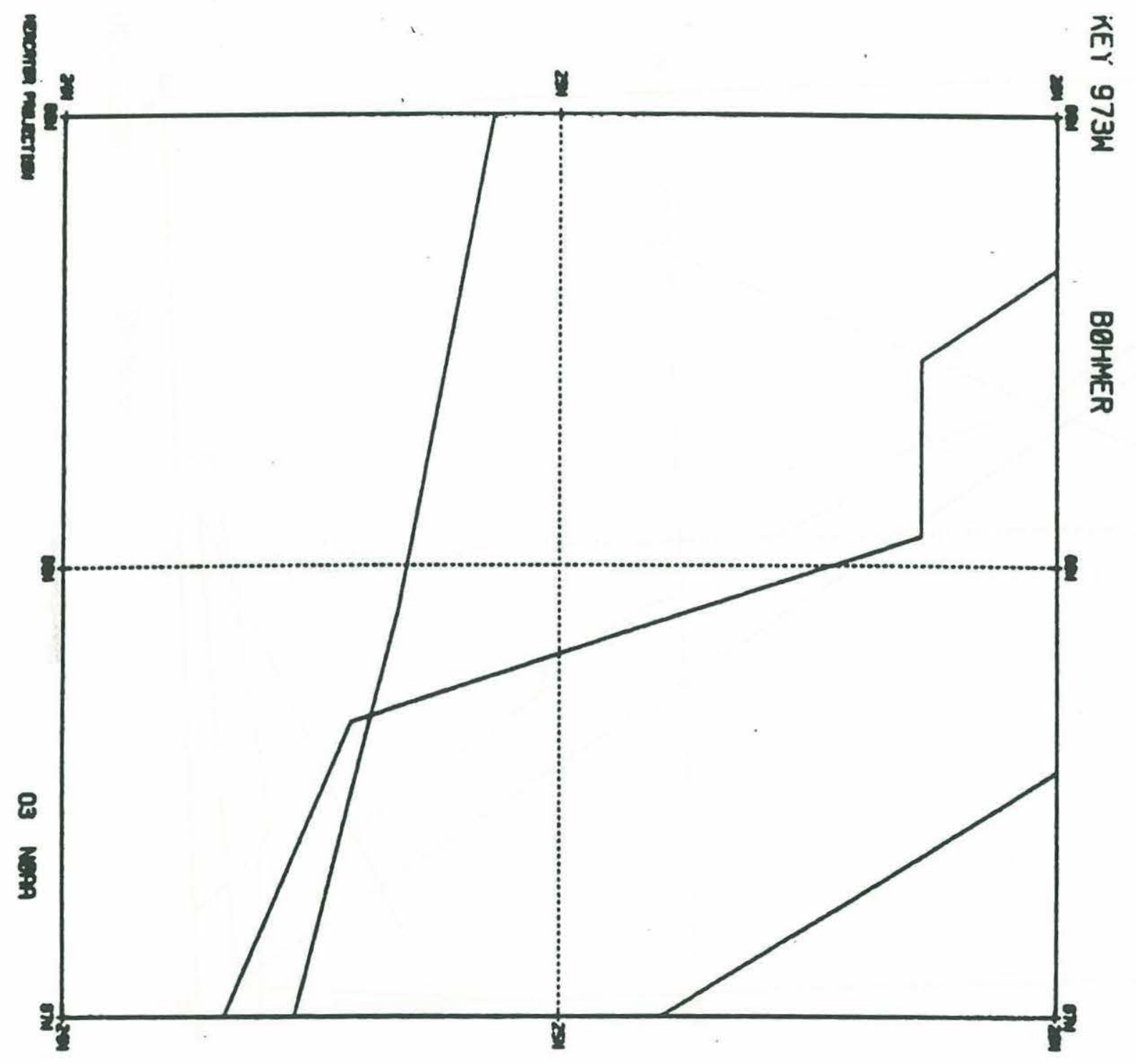


Figure 44h. Tracklines by U.S. Navy vessels archived in the NGDC.

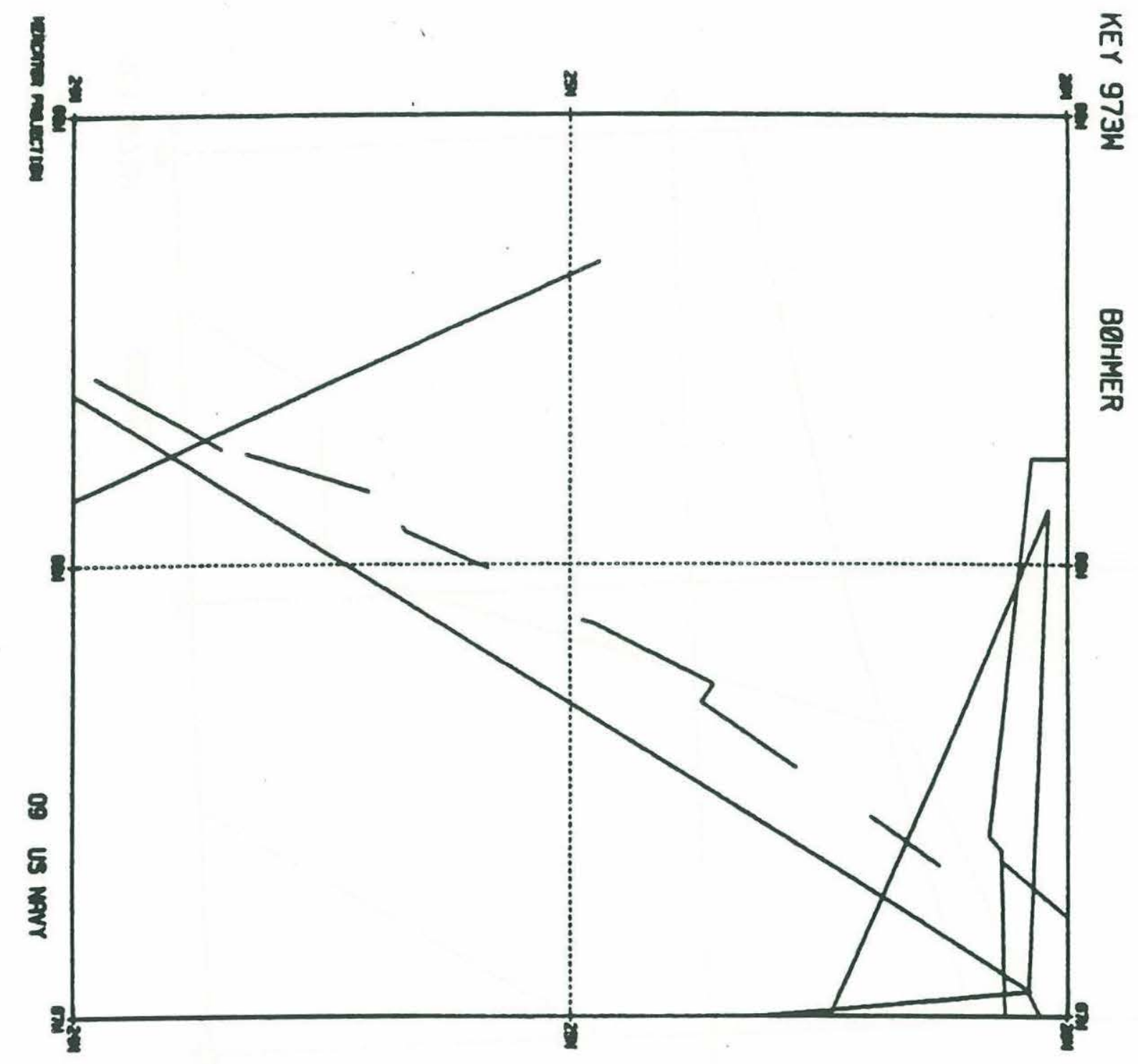


127

Figure 44i. Tracklines by Texas A\&M University vessels ärchived in the NGDC.

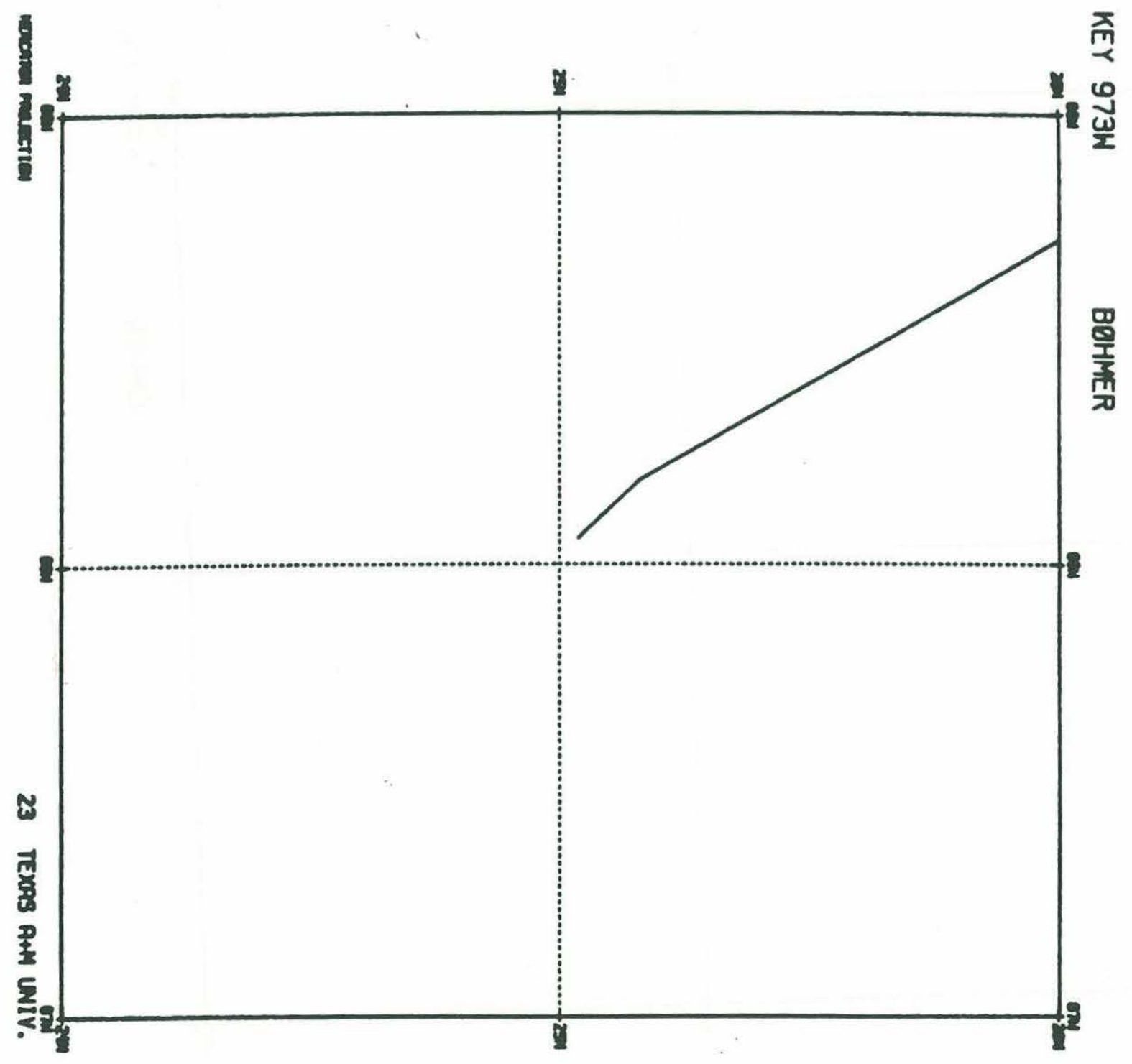


Figure $44 j$. Tracklines by Univ. of Rhode Island vessels ärchived in the NGDC.

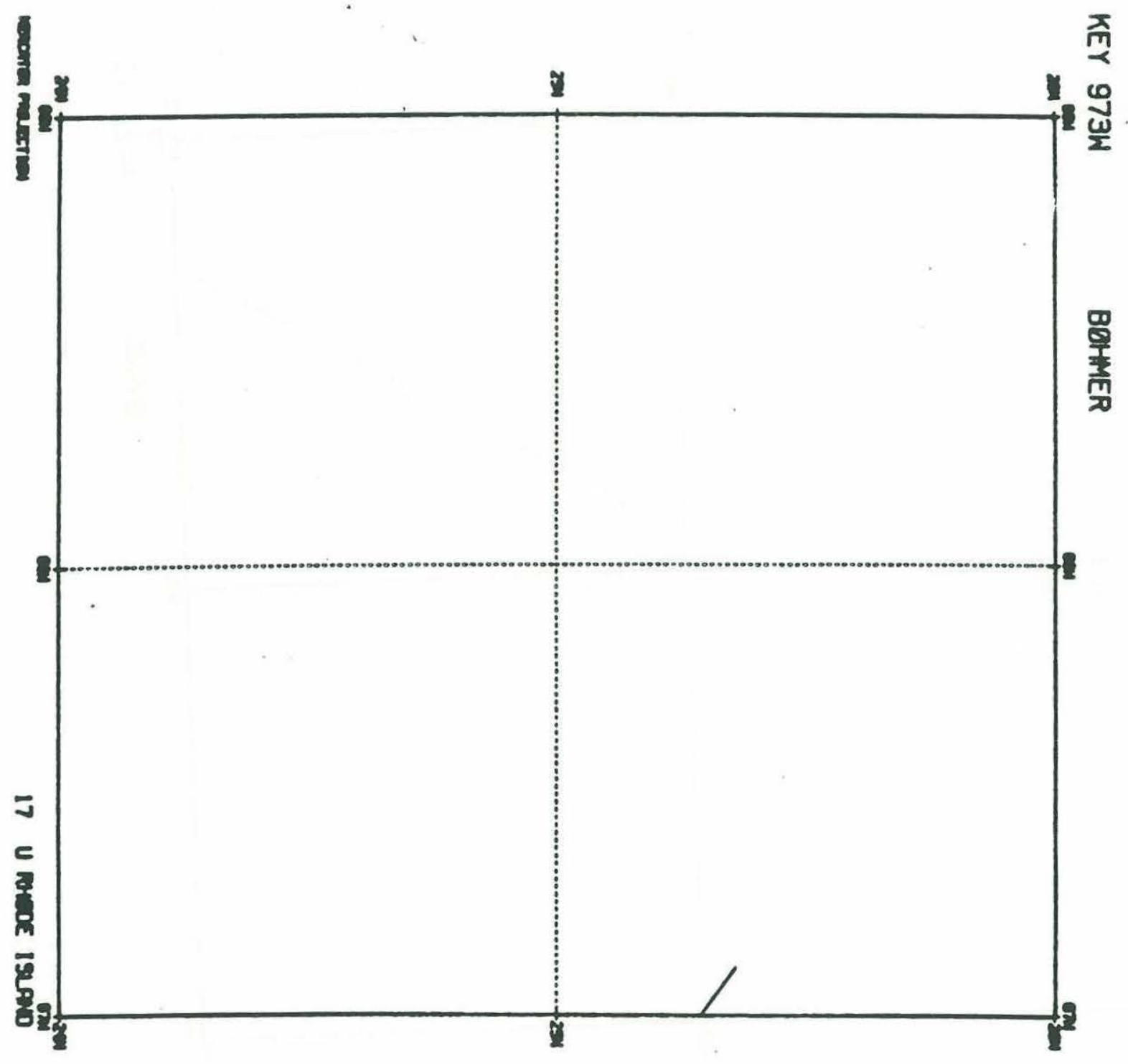


regions of low seafloor relief such as Sites 417/418, significant crossover errors are common. As a result, the relative locations of observations collected by different vessels are in doubt even when more accurate bottom transponder methods have been used.

NGDC did not return information on how each cruise was navigated. Table 16 shows navigation methods inferred for the most significant cruises. Sites $417 / 418$ are outside the range of reliable, consistent Loran C navigation. Sky waves are common and diurnal variation in locations are too great for accurate navigation. Satellite navigation is not available at all times of day so large windows of deduced reckoning must be used. As a result, neither Loran $\mathrm{C}$ nor satellite navigation are satisfactory for accurate surveying.

Two other problems have arisen in processing navigation data. First, the ATLANTIS II 97-2 cruise navigated a deep-towed hydrophone seismic survey with a bottom transponder network. Because of uncertainty in the locations of their transponders, bathymetry data from their cruise has been difficult to integrate with that from other bottom navigated cruises. Second, during ODP Leg 102 the FRED MOORE navigated relative to the drillship by radar and observer-reported azimuth. Latitude and longitude were resolved by using the DSDP reported location of Hole 418A. This method provides accurate ranging, especially when shooting outside the bottom transponder network near Sites $417 / 418$. Errors in location at up to $8 \mathrm{~km}$ range are less than $\pm 10 \mathrm{~m}$ relative to the drillship. Significant error, however, was discovered in traveltimes due to changing offset of the drillship from the borehole by hundreds of meters (Swift et al., 1988).

$\underline{\text { Cores }}$

NGDC searched its files for surface sediment cores in the region $24^{\circ}$ to $26^{\circ} \mathrm{N}$ latitude and $67^{\circ}$ to $69^{\circ} \mathrm{W}$ longitude. We also searched the files of the WHOI core repository. Table 17 lists these two data sets by research vessel. 
造选

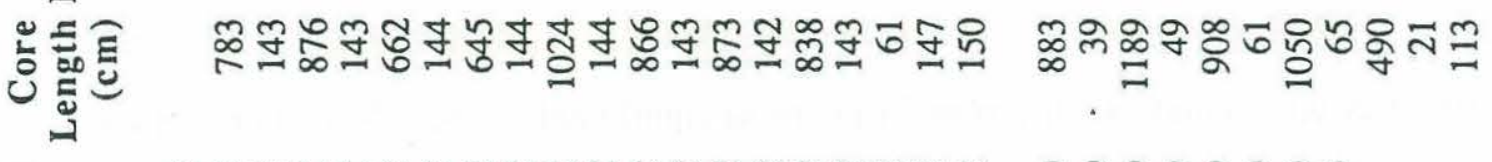

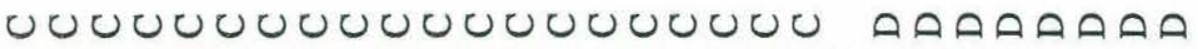

$\Leftrightarrow$

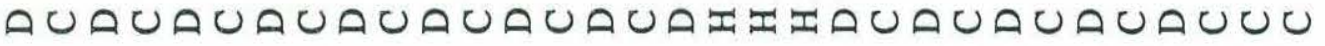

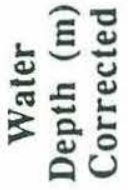

œ

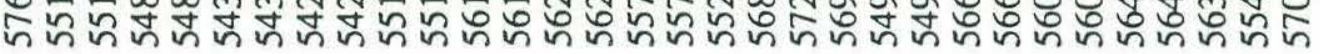

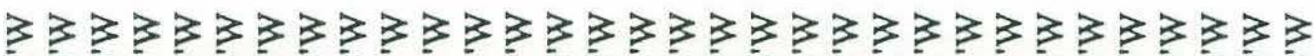

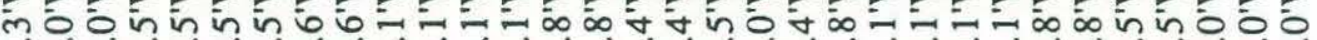

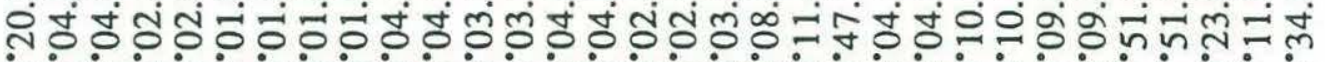
宑

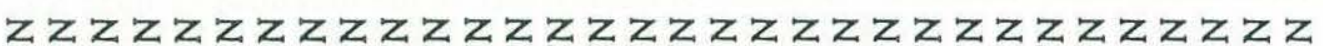

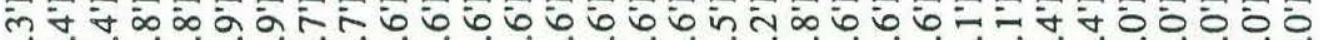
o

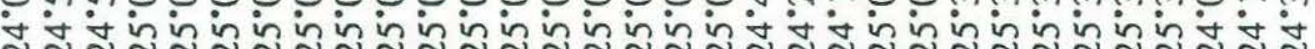

究园

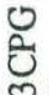

201 ษ

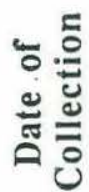
テ

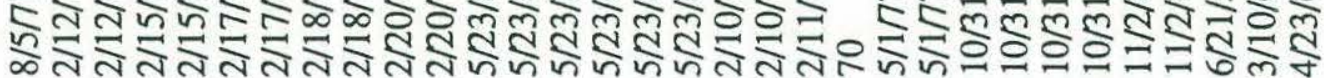

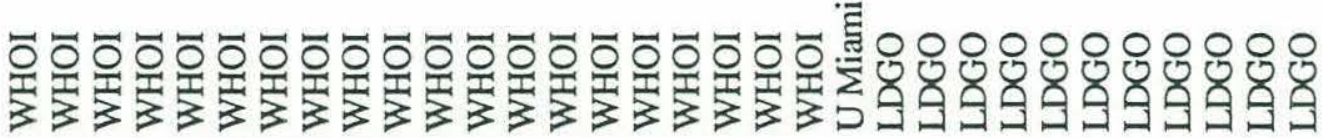
๙

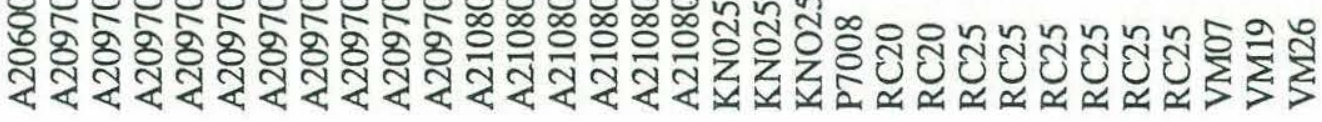

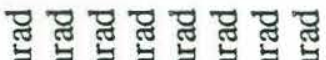

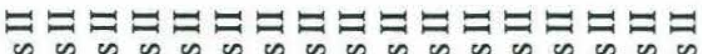

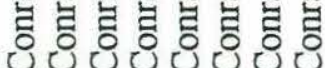

$\frac{2}{\sqrt{n}}$

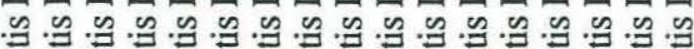

入Uல 


\section{ENGINEERING REPORTS}

\section{Cone Specifications}

In order to design the $\mathrm{BCU}$ frame and to provide supporting information for the reentry effort, we carried out engineering review of the cone, casing, and casing hanger assembly used at Sites 417 and 418. Storms and Gerken (1983) is a synopsis of the engineering blueprints used to manufacture the cone and hanger assemblies. However, at the time of deployment (1977) the systems were in the development stage and not all modifications were well documented. We present here three possible descriptions: i) the WHOI interpretation of what the cone and hanger assemblies look like (this is based on a synthesis of data available from DSDP and ODP by A. Bocconcelli and a discussion by R. Stephen and P. Thompson at ODP); ii) a version of the WHOI drawings corrected by D. Huey at ODP (Huey admits in his letter of August 2, 1988, that there are some uncertainties in dimensions) and iii) an actual photograph of the re-entry cone at Site 396 , east of the Mid-Atlantic Ridge, which was deployed on DSDP Leg 46 just one year before the deployment of the Site 417 and 418 cones.

The WHOI interpretation of the re-entry cone dimensions is given in Figure 45. This is an assembly diagram and the drawing numbers for the individual pieces are indicated. These drawings are included in DSDP Technical Report No. 13. The unit consists of a cone with a skirt to prevent it from sinking into the sediment. The cone rim is 9.65' above the bottom of the skirt and the cone O.D. is 14.48'. On the rim of the cone are three sonar reflectors. In addition three sonar reflectors are suspended above the cone by 10 " glass spheres. The photo reconnaissance survey will try to confirm the presence and condition of these reflectors. The cone leads into a casing hanger assembly below the skirt. In some designs three tubes lead from the casing hanger assembly to the rim of the skirt to carry drill cuttings out of the hole. The assemblies at Site 417 and 418 are dual casing assemblies designed to suspend casing with diameters of $16 "$ and 11-3/4" at the same time. 


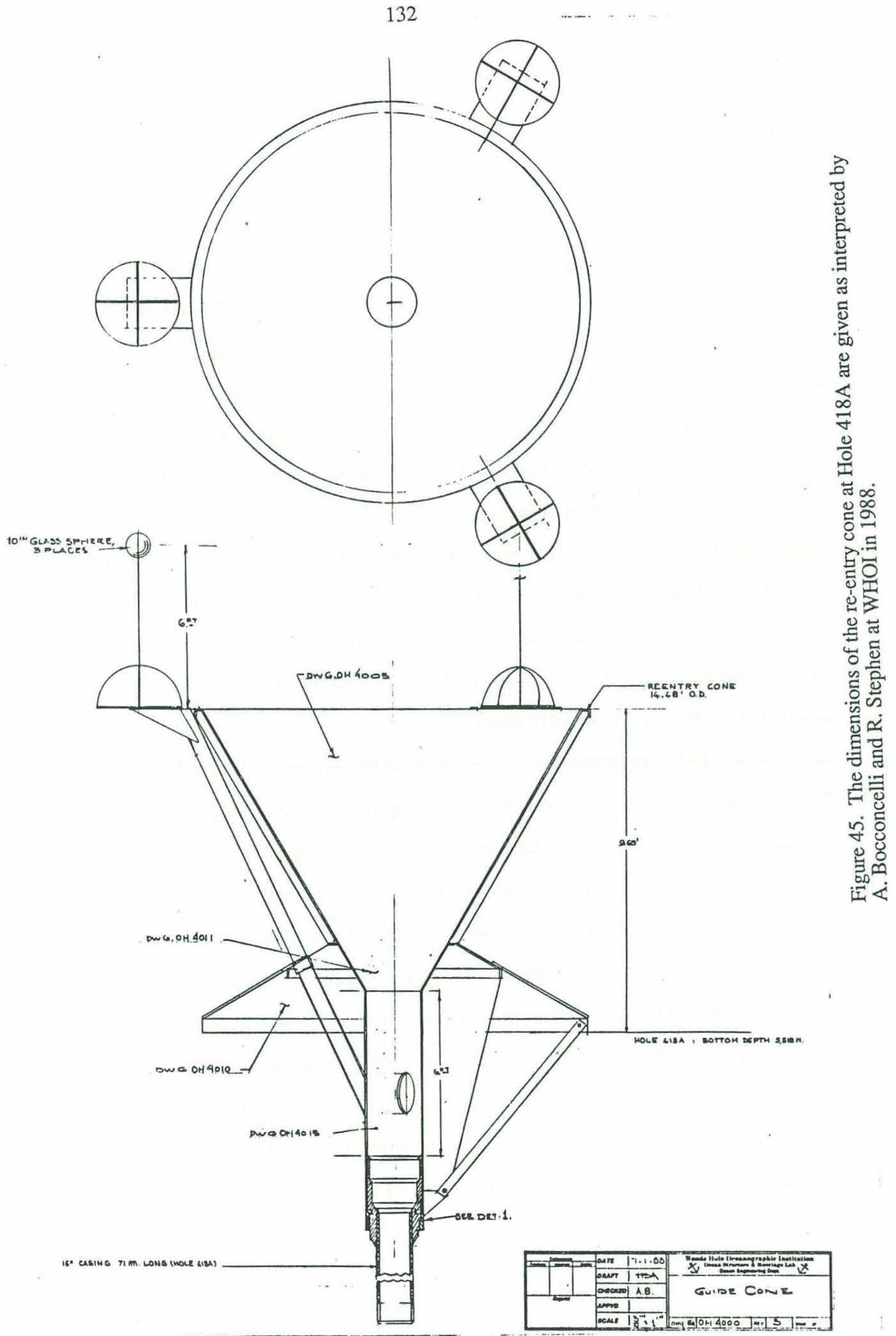


Only $16 "$ casing was actually deployed in these holes. Hole 417D has $25 \mathrm{~m}$ of 16 " casing and Hole $418 \mathrm{~A}$ has $71 \mathrm{~m}$ of $16 "$ casing.

A detailed assembly drawing of the casing hanger assembly is shown in Figure 46. The bottom of the cone has an inside diameter of $24 "$. The outside diameter of the casing is $16 "$ and it weighs $75 \mathrm{lb} /$ foot. The corresponding inside diameter is $151 / 8 "$.

The above drawings were sent to Dave Huey at ODP for confirmation of dimensions. He agreed that actual dimensions are difficult to obtain, but he made some changes to our values. The drawings annotated by Huey are given in Figures 47 and 48 . Thus, figures 45-48 illustrate the present level of uncertainty in these numbers.

In July-August 1988, IFREMER dove on Site 396B with their deep diving submersible NAUTILE. They deployed the re-entry device NADIA which is described by Legrand et al. (in press). Since the cone at Site 396 was deployed just a year before the cones at 417 and 418, the condition of the cones after twelve years on the seafloor should be similar. A photograph of the 396 re-entry cone is shown in Figure 49. The top of the cone is one meter below the seafloor. This was due to miscounting casing stands on deployment and was suspected in 1977. (We do not expect the cones at 417 and 418 to have sunk into the seafloor.) Otherwise the cone is in excellent mechanical condition. The casing was open to basement $(170 \mathrm{~m})$. Five re-entries were made with the submersible to a maximum depth of $301 \mathrm{~m}$. This test of the NADIA system demonstrated the feasibility of re-entering boreholes on the seafloor without the drill ship more than ten years after the drilling.

\section{Operations Resumes}

Sites 417 and 418 were drilled on Legs 51,52 and 53 of DSDP. The cruise operations managers wrote notes on the cruise operations for each leg (Foss and Knapp, 1980). The notes contain steaming times, hole locations, drilling summaries, descriptions of problems, etc. These notes provide useful background information on the sites in addition to the summary papers in the Initial Reports. 


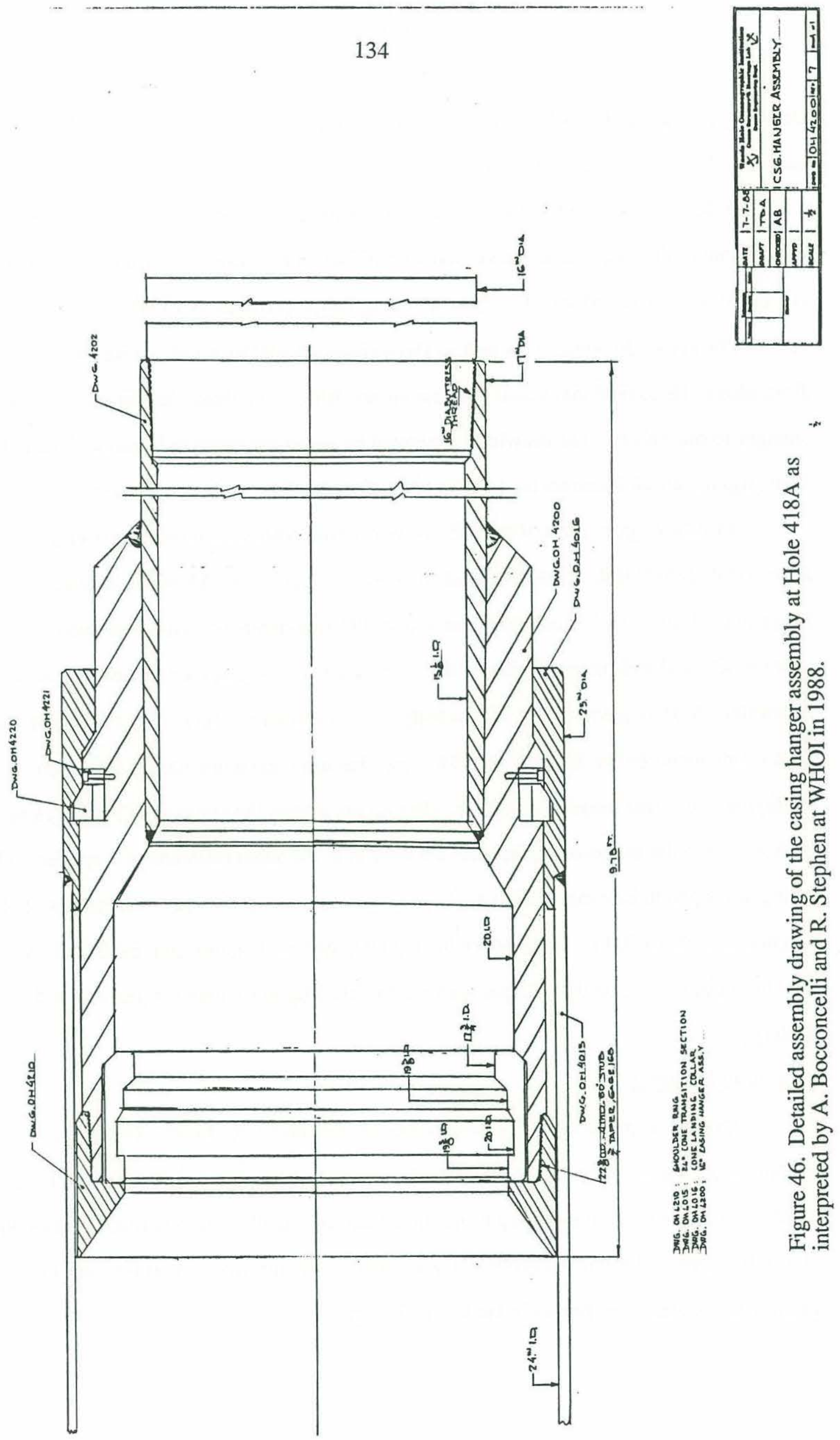




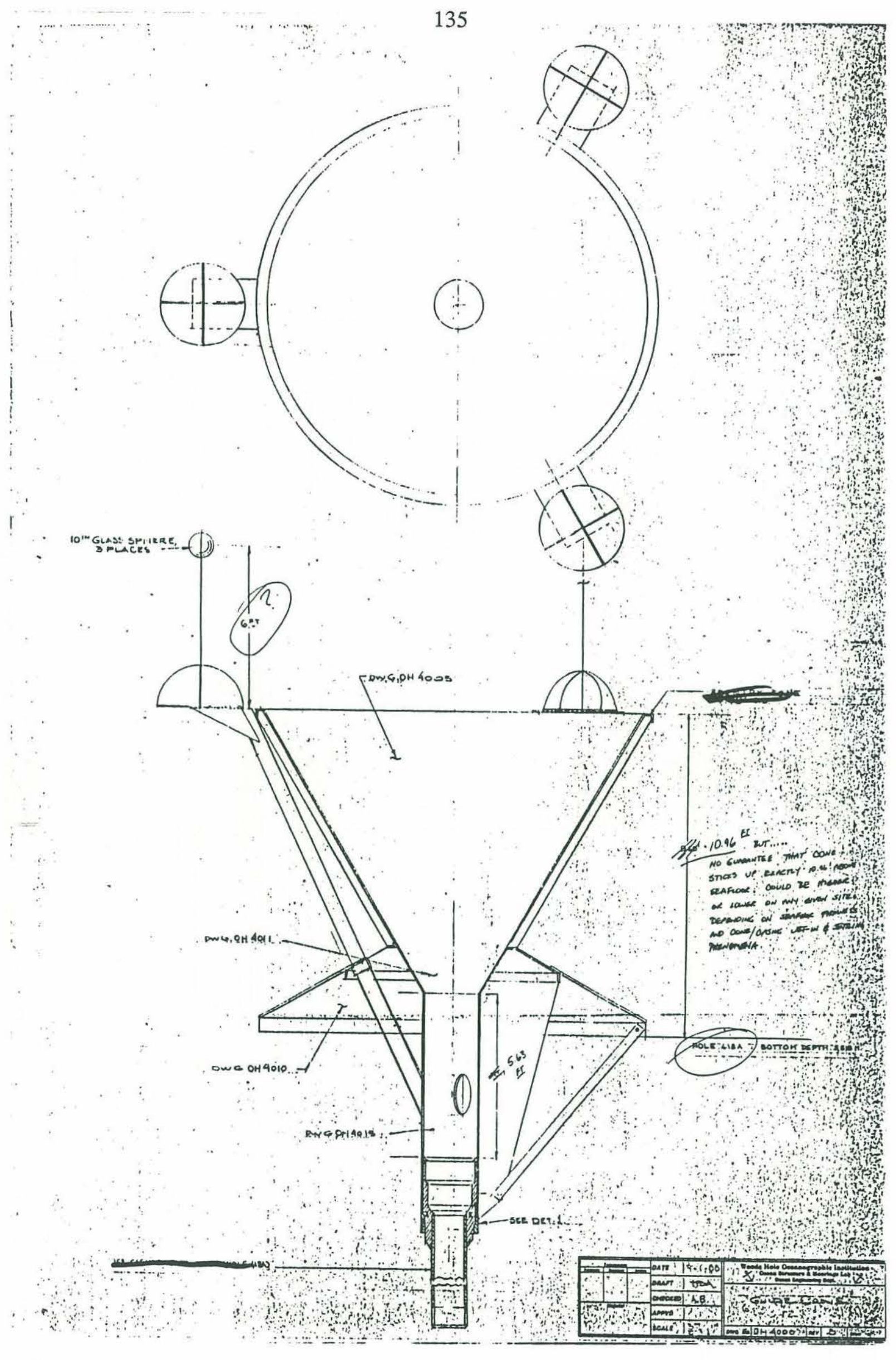

Figure 47. This is the same as Figure 45 but with annotations by Dave Huey of ODP in 1988. The changes reflect the uncertainty at this time in the cone dimensions. 


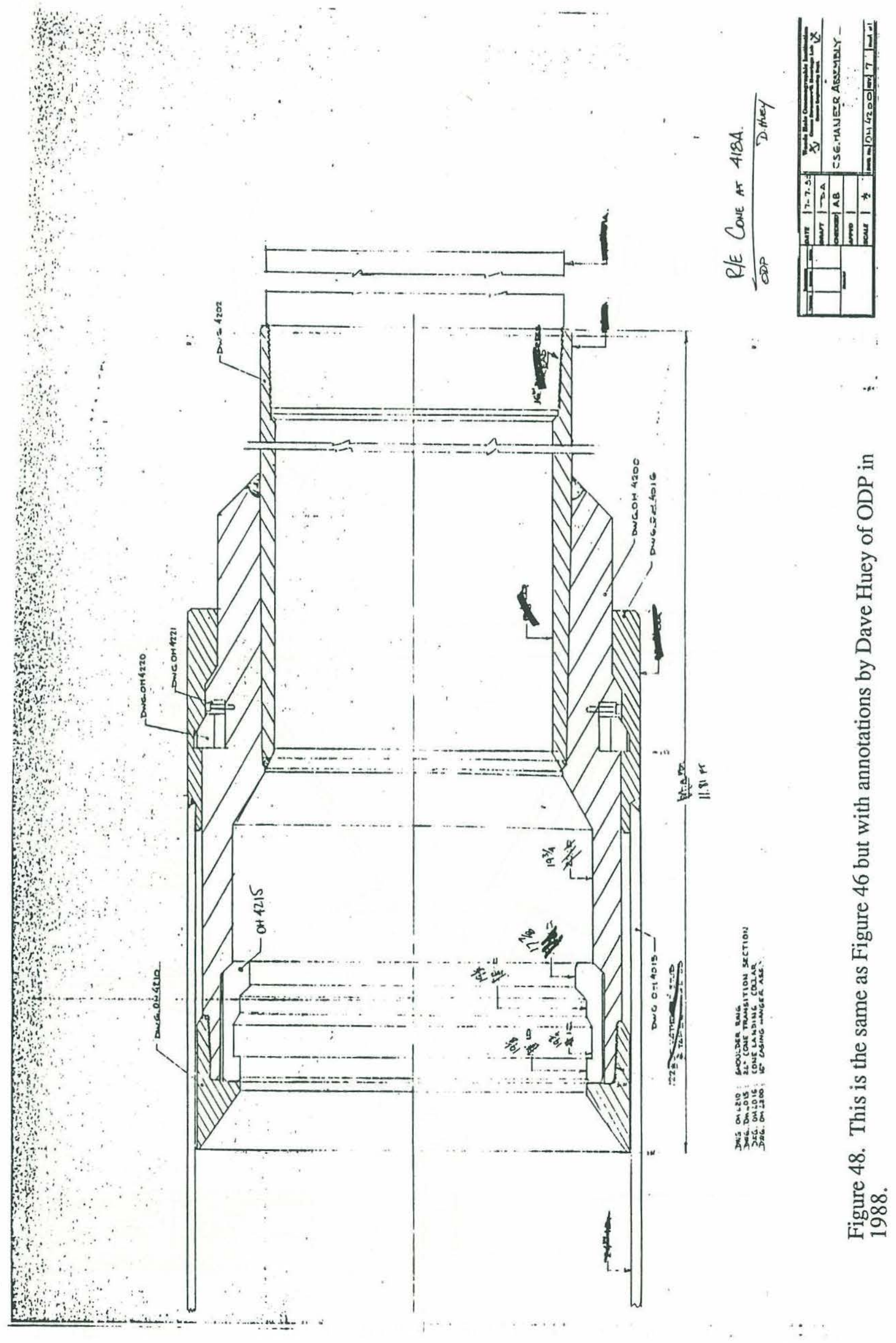




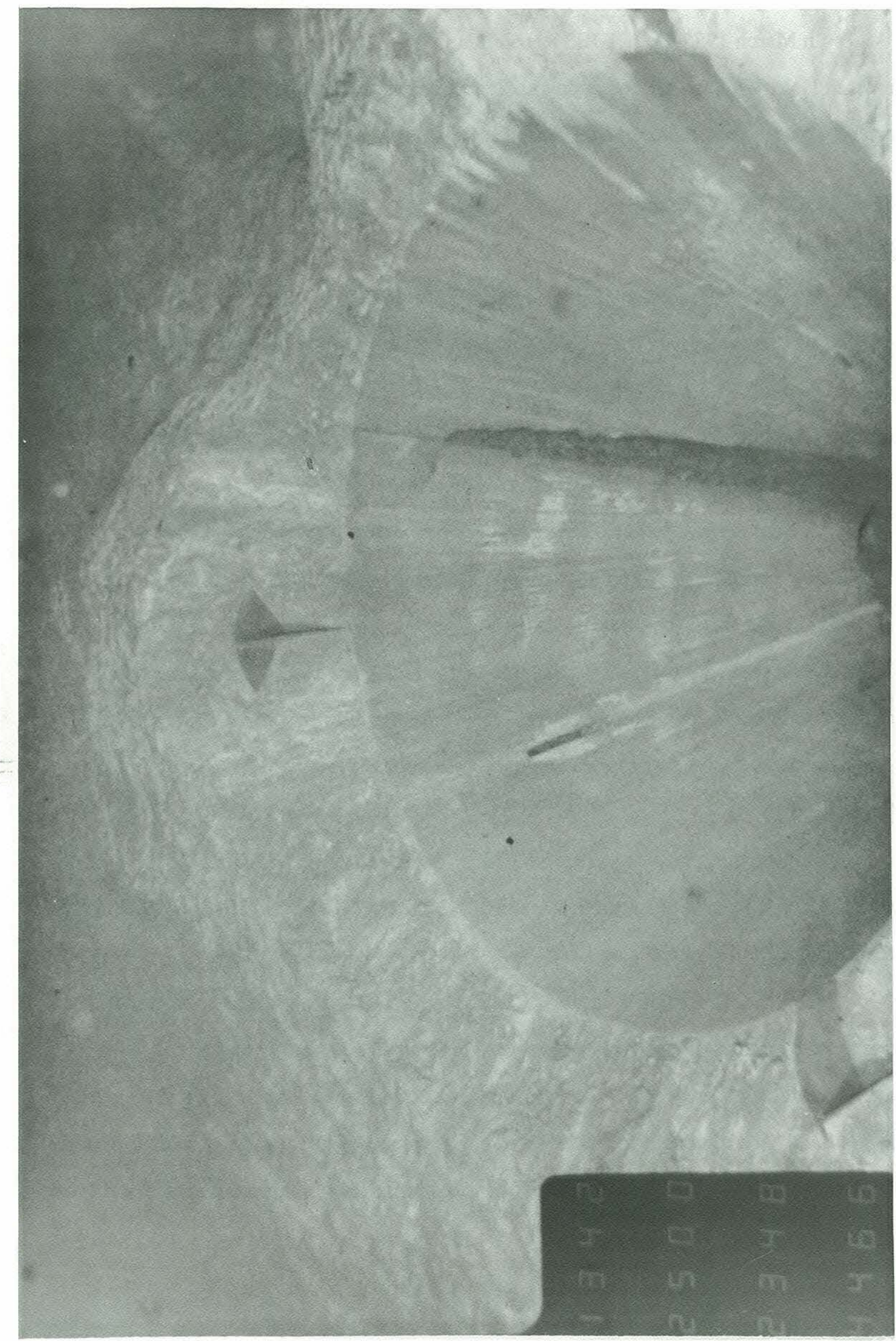

 
In March 1985 the JOIDES Resolution (Leg 102) returned to Site 418 and reentered Hole 418A to carry out a downhole measurements program. The operations of this cruise are described in Foss and Thompson (1985).

\section{SEAFLOOR OBSTACLES}

\section{DSDP Cones}

We obtained revised locations of boreholes drilled by DSDP from Glenn Foss, drilling superintendent at ODP. Table 18 lists locations of all holes and indicates whether a cone is present. There are differences of up to $150 \mathrm{~m}$ between these locations and those reported in Table 1 taken from Donnelly et al. (1980). In particular, Foss's revised location for Hole $418 \mathrm{~A}$ is $\sim 110 \mathrm{~m}$ north of the published location.

For the purposes of relocation, Foss also reported that the cone at Hole $417 \mathrm{C}$ is blocked by a short stub of drill string in the lower part of the cone. No drilling was done at Hole 417C, and there should be no drill cuttings on or around the cone. The single-bit holes should show a disturbance in the immediate area and a conical structure of drill cuttings with crater on the top. Foss reports observing these structures with their highresolution Mesotech sonar system deployed below the drill string. Transponders

Bottom transponders were deployed by three legs of the GLOMAR CHALLENGER (DSDP Legs 51, 52, and 53), by the ATLANTIS II on Leg 97-2, and by the SEDCO/BP 471 (ODP Leg 102).

On the ATLANTIS II cruise, G.M. Purdy (WHOI) deployed six transponders weighted by concrete anchors and recovered the transponders at the end of the survey. The anchors left behind may have sunk into the surface sediment or been covered by current swept mud. The transponder locations were determined by integrating acoustic ranging and satellite fixes. Table 19 lists the locations determined from the location map in Figure 3 of Purdy et al. (1980). 
Table 18. Borehole locations from G. Foss (personal communication)

\section{DRILL HOLE LOCATIONS}

\section{HOLE\# LATITUDE LONGITUDE SEAFLOORDEPTH in meters}

\begin{tabular}{|c|c|c|c|c|c|c|}
\hline 417 & $25^{\circ}$ & $06.71^{\prime} \mathrm{N}$ & $68^{\circ}$ & $02.57^{\prime} \mathrm{W}$ & 5478.2 & single-bit \\
\hline $417 \mathrm{~A}$ & $25^{\circ}$ & $06.63^{\prime}$ & $68^{\circ}$ & 02.48' & 5478.2 & single-bit \\
\hline $417 B$ & $25^{\circ}$ & $06.65^{\prime}$ & $68^{\circ}$ & 02.78' & 5489 & single-bit \\
\hline $417 \mathrm{C}$ & $25^{\circ}$ & $06.56^{\prime}$ & $68^{\circ}$ & $02.63^{\prime}$ & 5489 & cone \\
\hline 417D & $25^{\circ}$ & $06.69^{\prime}$ & $68^{\circ}$ & $02.82^{\prime}$ & 5489 & cone \\
\hline 418 & $25^{\circ}$ & $02.08^{\prime} \mathrm{N}$ & $68^{\circ}$ & $03.45^{\prime} \mathrm{W}$ & 5519 & single-bit \\
\hline $418 A$ & $25^{\circ}$ & $02.16^{\prime}$ & $68^{\circ}$ & $03.44^{\prime}$ & 5519 & cone \\
\hline $418 B$ & $25^{\circ}$ & $02.17^{\prime}$ & $68^{\circ}$ & 03.45' & 5523 & single- - \\
\hline
\end{tabular}


Table 19. Locations of WHOI transponder anchors. Latitude and
longitude picked from Figure 3 in Purdy et al. (1980).

\section{PURDY TRANSPONDER NETWORK̄ ANCHORS}

\begin{tabular}{ll} 
Latitude & \multicolumn{2}{c}{ Longitude } \\
$25^{\circ} 07.95^{\prime} \mathrm{N}$ & $68^{\circ} 01.23^{\prime} \mathrm{W}$ \\
$25^{\circ} 06.98^{\prime}$ & $68^{\circ} 03.63^{\prime}$ \\
$25^{\circ} 04.79^{\prime}$ & $68^{\circ} 00.77^{\prime}$ \\
$25^{\circ} 04.14^{\prime}$ & $68^{\circ} 04.70^{\prime}$ \\
$25^{\circ} 01.75^{\prime}$ & $68^{\circ} 02.03^{\prime}$ \\
$25^{\circ} 00.06^{\prime}$ & $68^{\circ} 05.50^{\prime}$
\end{tabular}


At Site 417, five transponders were deployed on DSDP Leg 51 and 52. At Site 418, four transponders were deployed on DSDP Legs 52 and 53, and three transponders were deployed on ODP Leg 102. The DSDP transponders, manufactured by ORE, are enclosed in three-foot-long cylindrical pressure cases. DSDP rigged the transponders to float 5 to 6 feet above the seafloor. Five to six glass ball "hard hats" were attached to the top of the transponder. The ODP transponders, manufactured by DATASONICS, are in white plastic cases 5 feet long and 10 inches in diameter. Glenn Floss reports that glass ball flotation is inside the plastic casing. He does not report how far off the seafloor they are tethered.

The location of the 13 drilling ship transponders is very poorly known. Our primary source for transponder locations is a personal communication from Glenn Foss. The original dynamic positioning data was not available or unrecorded. In recovering locations from shipboard records, Foss found duplicate, contradictory locations for several transponders. He provided fixes as range and bearing from boreholes. Thus, the total uncertainty in transponder fix includes the error in hole location. Table 20 lists the available data. Figures 50 and 51 show locations of boreholes (from Table 18) and the locations of transponders using Foss's data (Table 20). The range between duplicate fixes ranges up to 1600 feet at Site 417 and 750 feet at Site 418.

Drilling Gear

DSDP Leg 53 reported loss of a logging tool and $300 \mathrm{~m}$ of logging cable in Hole 418A. ODP Leg 102, however, was able to deploy logging gear to nearly the full depth of penetration. The lost gear, then, must be on the seafloor in the immediate vicinity of Hole 418A. In addition, drilling crews discarded plastic core liners of various sizes during drilling operations. Glenn Foss suggests that the seafloor around Sites 417D and 418A, the two holes with the longest drilling history, are probably strewn with these liners. 
Table 20. Locations of DSDP and ODP transponders from G. Foss (personal communication).

\section{DSDP \& ODP TRANSPONDER LÖCATIONS}

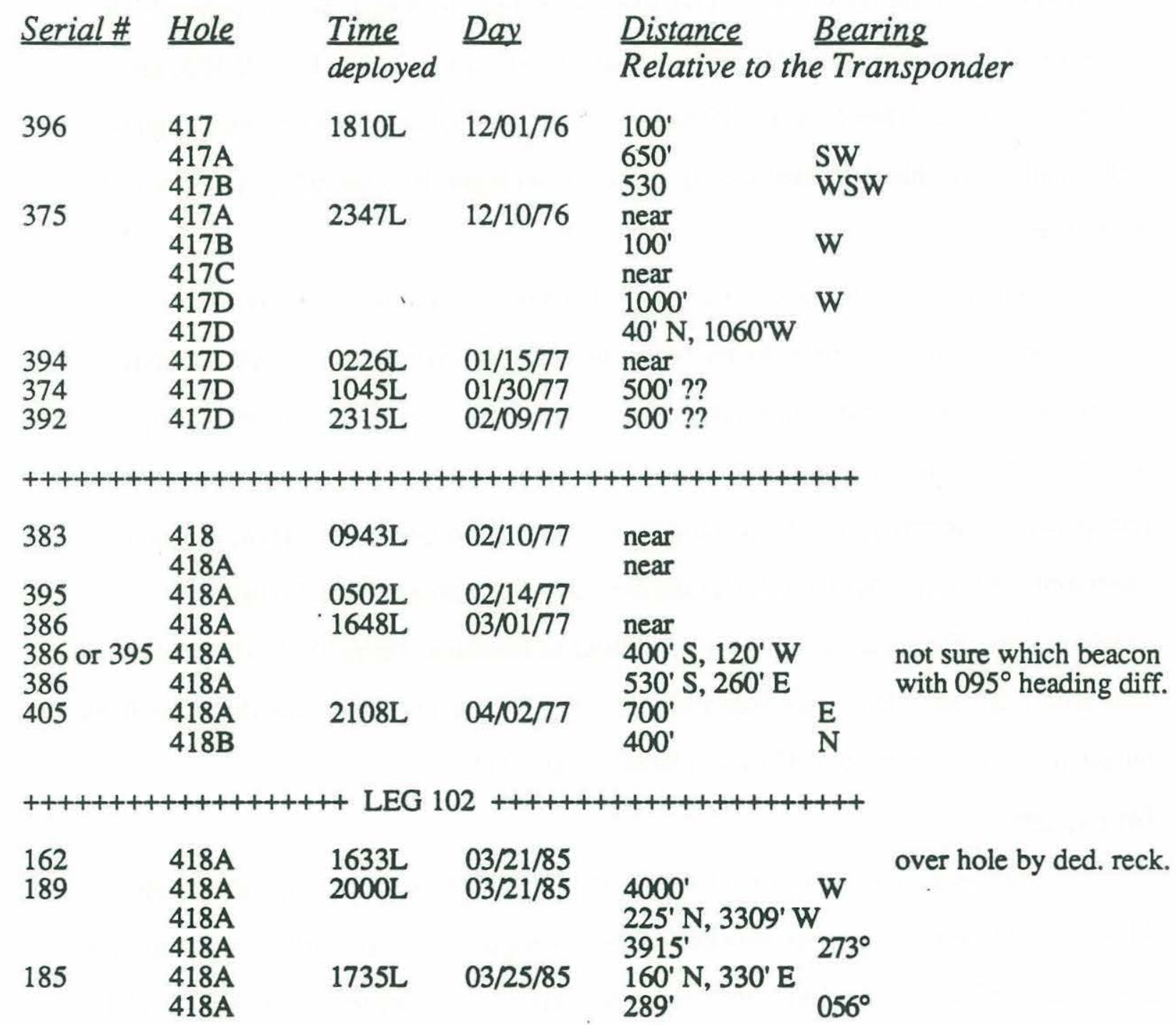


Figure 50. Location of DSDP and ODP transponders and cones at Site 417 from G. Foss (personal communication).

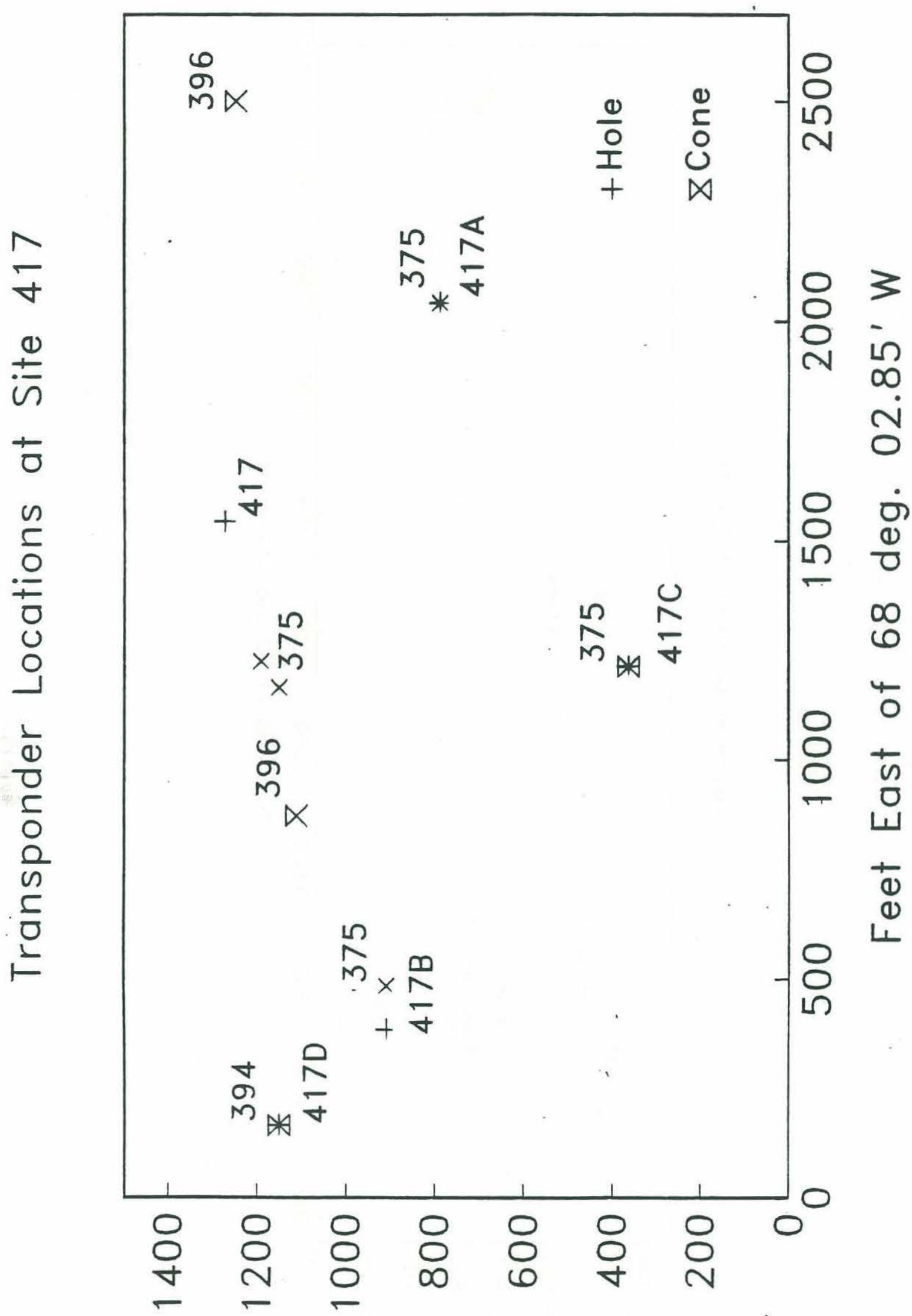

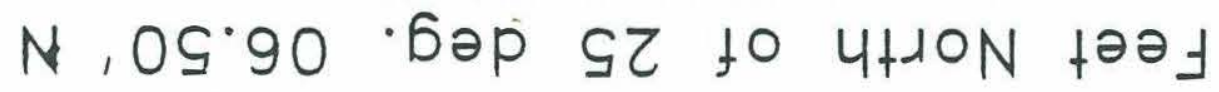


Figure 51. Location of DSDP and ODP transponders and re-entry cones at Site 418 from G. Foss (personal communication).

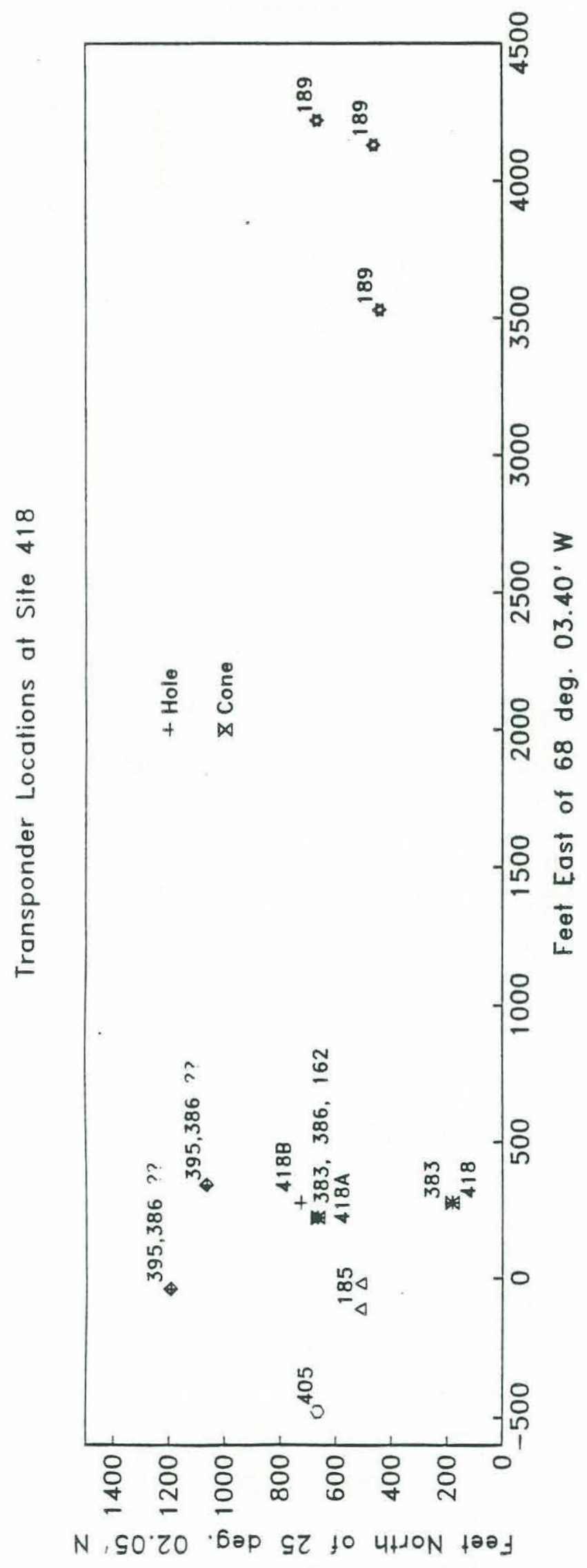




\section{PHYSICAL OCEANOGRAPHY}

Sites 417 and 418 lie near the subtropical convergence between tradewinds to the south and westerlies to the north. In terms of surface water circulation, the sites lie on the southwestern edge of the subtropical gyre (Sargasso Sea). A great number of moored current meter measurements and float tracks have been gathered just north of Sites 417/418 at $28^{\circ} \mathrm{N}$ since the 1970s as part of Mid Ocean Dynamics Experiment (MODE, 1978; Schmitz, 1989). The mean flow, as determined by geostrophic computation and long-term Eularian and Lagrangian observations, is a few $\mathrm{cm} / \mathrm{s}$ easterly in the upper $2000 \mathrm{~m}$ and southerly at deeper depths (Schmitz, 1976; Reid, 1978; Owens et al., 1988). Although this site is within a region of the North Atlantic with low kinetic energy in upper-to-middle water depths, significant variability in velocity occurs due to transit of eddies (Riser and Rossby, 1983; Rossby et al., 1983).

Eddies are anticyclonic water motions with lateral scales of 10 's to 100 's of kms and temporal scales of months to a year or so (MODE, 1978). Within eddies, current velocity can reach $50 \mathrm{~cm} / \mathrm{s}$ (McWilliams, et al., 1983). Eddies propagate at speeds of 2-4 $\mathrm{km}$ per day. The presence of an eddy can be recognized by vertical temperature structure. Normally the $15^{\circ} \mathrm{C}$ isotherm occurs at 500-600 $\mathrm{m}$ depth in this region (MODE, 1978). This isotherm rises to $300-400 \mathrm{~m}$ depth in the center of eddies.

There is considerably less data on deep water flow. Tucholke et al. (1973) took sections of salinity and temperature across the Vema Gap. He found moderate westerly flow of Antarctic Bottom Water near Sites 417/418. This is consistent with an isothermal bottom boundary layer observed by Galson and Von Herzen (1981) and thought to be due, in part, to horizontal advection and thickening processes (Armi and Millard, 1976; Armi and D'Asaro, 1980).

The temperature and salinity characteristics at the site may be gleaned from atlases of data collected in the 50's and 60's (Fuglister, 1960; Worthington and Wright, 1970; Wright and Worthington, 1970). Worthington (1976) synthesized these data into a 
circulation model for the western North Atlantic. We have ordered temperature, salinity and computed sound velocity data for this region from the National Ocean Data Center. Figure 52 shows profiles of sound velocity in the upper $2500 \mathrm{~m}$ from a Naval atlas.

\section{ACKNOWLEDGEMENTS}

We thank Susan Humphris and Hartley Hoskins for reviewing the manuscript. This research was supported by Johns Hopkins University, Applied Physics Laboratory, letter contract no. 602809-0. 
Figure 52a. Vertical profiles of sound velocity computed from temperature and salinity data in upper $2500 \mathrm{~m}$ (Marsden square 79, one degree square 45).

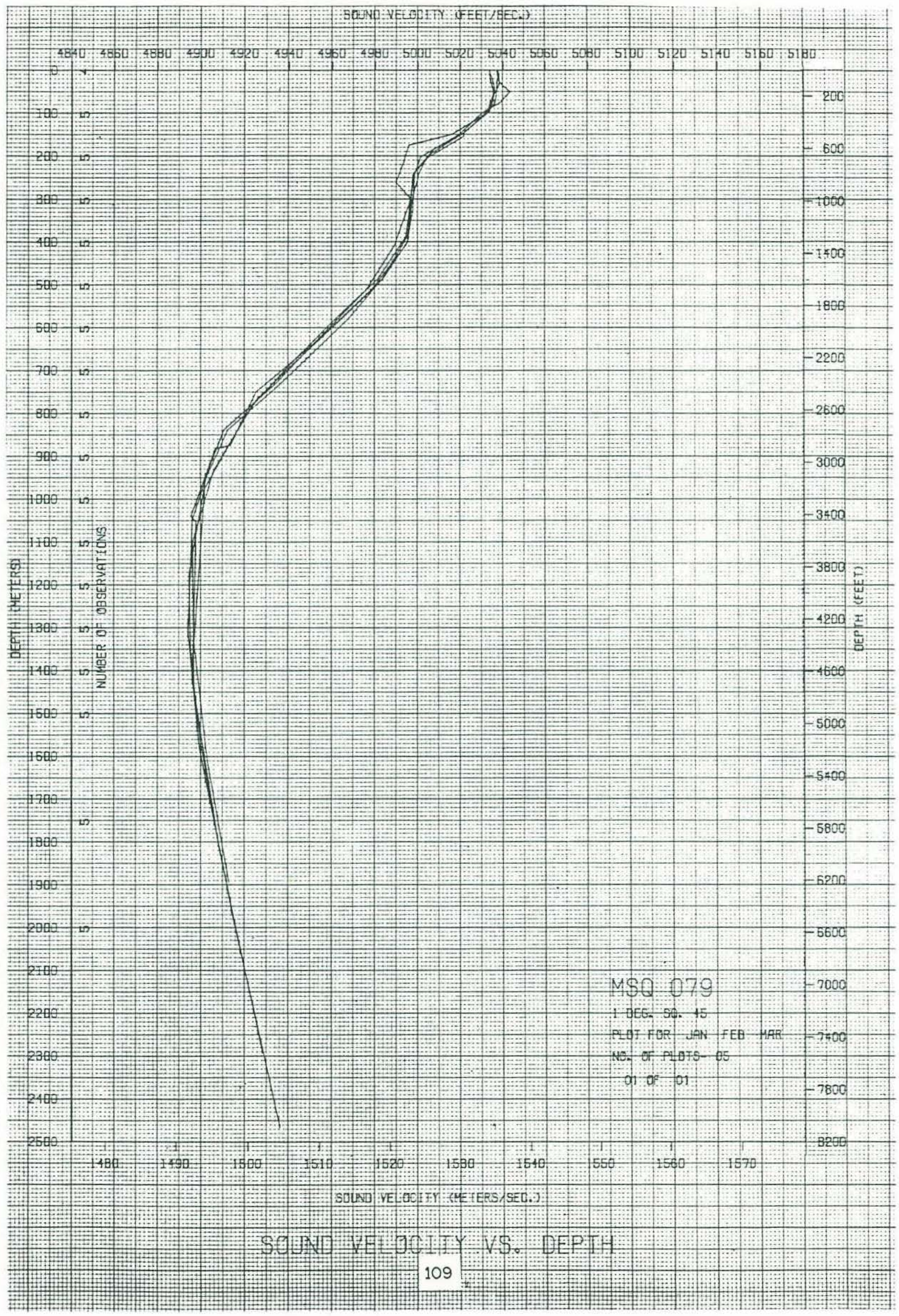


Figure 52b. Profiles of velocity of sound in water (Marsden square 79, one degree square 46).

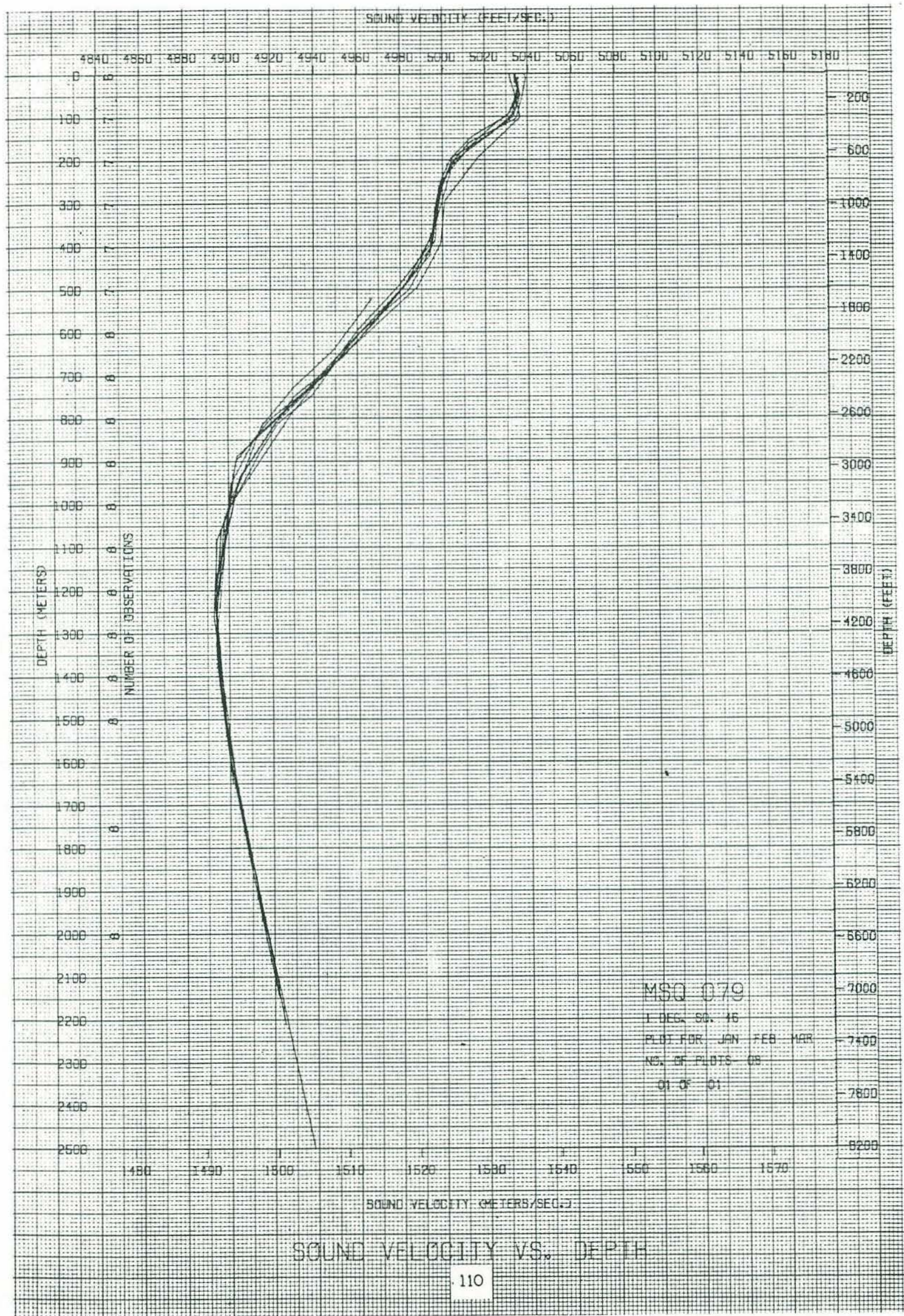




\section{REFERENCES}

Alt, J.C. and Honnorez, J., 1984. Alteration of the upper crust, DSDP Site 417: mineralogy and chemistry. Contrib. Mineral. Petrol., v. 87, p. 149-169.

Armi, L., and D'Asaro, E., 1980. Flow structures in the deep ocean. J. Geophy. Res. $\underline{85}$, p. $469-484$.

Armi, L. and Millard, R.C., 1976. The bottom boundary layer of the deep ocean. J. Geophy. Res. 81, p. 4983-4990.

Arthur, M.A. and Dean, W.E., 1986. Cretaceous paleoceanography of the western North Atlantic Ocean. In: Vogt, P.R. and Tucholke, B.E., (eds.), The geology of North America, vol. M, The western North Atlantic region., p. 617-630.

Auroux, C.A. and Stephen, R.A., 1986. Geophysical profiling, ODP Leg 102. In: Salisbury, M.H., Scott, J.H., Auroux, C.A., et al., Proc. Init. Repts. (Part A), ODP, p. 7-91.

Bleil, U. and Smith, B., 1980a. Paleomagnetism of basalts, Leg 51. In Donnelly, T., et al., Initial Reports of the DSDP, v. 51, 52, 53, Part 2: Washington (U.S. Government Printing Office), p. 1351-1361.

Bleil, U. and Smith, B., 1980b. Petrology of magnetic oxides at Site 417. In Donnelly, T., et al., Initial Reports of the DSDP, v. 51, 52, 53, Part 2: Washington (U.S. Government Printing Office), p. 1411-1428.

Bollinger, C. and Semet, M., 1980. Chemical zonation of plagioclase phenocrysts from Leg 51, 52, and 53 basalts. In Donnelly, T., et al., Initial Reports of the DSDP, v. 51, 52, 53, Part 2: Washington (U.S. Government Printing Office), p. 1055-1061.

Borella, P.E. and Adelseck, C., 1980. Manganese micronodules in sediments: a subsurface in-situ origin, Leg 51, Deep Sea Drilling Project. In Donnelly, T., et al., Initial Reports of the DSDP, v. 51, 52, 53, Part 2: Washington (U.S. Government Printing Office), p. 771-787.

Bosum, W., and Scott, J.H., 1988. Interpretation of magnetic logs in basalt, Hole 418A. In Salisbury, M.H., Scott, J.H., 'et al., Proc. ODP, Sci. Results, 102: College Station, TX (Ocean Drilling Program), 77-95.

Bowin, C.O., Warsi, W., and Milligan, J., 1982. Free-air gravity anomaly atlas of the world: Geol. Soc. Amer. Map Chart Ser., MC-46.

Broglia, C., and Moos, D., 1988. In-situ structure and properties of 110-Ma crust from geophysical logs in DSDP Hole 418A. In Salisbury, M.H., Scott, J.H., et al., Proc. ODP, Sci. Results, 102: College Station, TX (Ocean Drilling Program), 29-47.

Bryan, G.M., 1980. Basement profiling with a deep-towed hydrophone near Deep Sea Drilling Project Site 417. In Donnelly, T., et al., Initial Reports of the DSDP, v. 51, 52, 53, Part 1: Washington (U.S. Government Printing Office), p. 671-673.

Bryan, W.B. and Frey, F.A., 1986. Petrologic and geochemical evolution of pre 1Ma western North Atlantic lithosphere. In P.R. Vogt and B.E. Tucholke (eds.), The 
geology of North America, v. M, The western North Atlantic region. Geol. Soc. Amer., p. 271-296.

Bukry, D., 1980. Eocene diatoms and siliceous sponge spicules from the northwestern Atlantic Ocean, Deep Sea Drilling Project Sites 417 and 418. In Donnelly, T., et al., Initial Reports of the DSDP, v. 51, 52, 53, Part 2: Washington (U.S. Government Printing Office), p. 851-855.

Byerly, G.R. and Sinton, J.M., 1980. Compositional trends in natural basaltic glasses from Deep Sea Drilling Project Holes 417D and 418A. In Donnelly, T., et al., Initial Reports of the DSDP, v. 51, 52, 53, Part 2: Washington (U.S. Government Printing Office), p. 957-971.

Carlson, R.L., Snow, K.R., and Wilkens, R.H., 1988a. Density of old oceanic crust: an estimate derived from downhole logging on ODP Leg 102. In Salisbury, M.H., Scott, J.H., et al., Proc. ODP, Sci. Results, 102: College Station, TX (Ocean Drilling Program), 63-68.

Carlson, R.L., Wilkens, R.H., Moos, D., and Broglia, C., 1988b. Correlations of sediment lithostratigraphy, downhole logs, and seismic reflectors at Site 418. In Salisbury, M.H., Scott, J.H., et al., Proc. ODP, Sci. Results, 102: College Station, TX (Ocean Drilling Program), 19-26.

Choukroune, P., 1980. Structural study of basaltic rocks showing brittle deformation (Deep Sea Drilling Project Legs 51, 52, and 53, sites 417 and 418). In Donnelly, T., et al., Initial Reports of the DSDP, v. 51, 52, 53, Part 2: Washington (U.S. Government Printing Office), p. 1491-1498.

Christensen, N.I. and Salisbury, M.H., 1975. Structure and constitution of the lower oceanic crust. Rev. Geophys. Space Phys., v. 13, p. 57-86.

Christensen, N.I., Blair, S.C., Wilkens, R.H., and Salisbury, M.H., 1980. Compressional wave velocities, densities, and porosities of basalts from Holes 417A, 417D, and 418A, Deep Sea Drilling Project Legs 51 through 53. In Donnelly, T., et al., Initial Reports of the DSDP, v. 51, 52, 53, Part 2: Washington (U.S. Government Printing Office), p. 1467-1471.

Clocchiatti, R., 1980. Glassy inclusions in plagioclase and pyroxene phenocrysts in the chilled margin of a pillow lava from Hole 417D, Deep Sea Drilling Project. In Donnelly, T., et al., Initial Reports of the DSDP, v. 51, 52, 53, Part 2: Washington (U.S. Government Printing Office), p. 1063-1067.

Deroo, G., Herbin, J.P., Roucaché, J., and Tissot, B., 1980. Organic geochemistry of Cretaceous sediments at DSDP holes 417D (leg 51), 418A (leg 52), and 418B (leg 53) in the western North Atlantic. In Donnelly, T., et al., Initial Reports of the DSDP, v. 51, 52, 53, Part 2: Washington (U.S. Government Printing Office), p. 737-745.

Donnelly, T.W., 1980. Chemistry of sediments of the western Atlantic: Site 417 compared with Sites 9, 105, 386, and 387. In Donnelly, T., et al., Initial Reports of the DSDP, v. 51, 52, 53, Part 2: Washington (U.S. Government Printing Office), p. $1515-1523$. 
Donnelly, T.W., Francheteau, J., Bryan, W., Robinson, P., Flower, M., Salisbury, M., et al., 1980. Initial Reports of the DSDP , v. 51, 52, 53, Parts 1 and 2: Washington (U.S. Government Printing Office).

Donnelly, T.W., Pritchard, R.A., Emmermann, R., and Puchelt, H., 1980a. The aging of oceanic crust: synthesis of the mineralogical and chemical results of Deep Sea Drilling Project Legs 51 through 53. In Donnelly, T., et al., Initial Reports of the DSDP, v. 51, 52, 53, Part 2: Washington (U.S. Government Printing Office), p. 1563-1577.

Donnelly, T.W., Thompson, G., and Salisbury, M.H., 1980b. The chemistry of altered basalts at Site 417, Deep Sea Drilling Project Leg 51. In Donnelly, T., et al., Initial Reports of the DSDP, v. 51, 52, 53, Part 2: Washington (U.S. Government Printing Office), p. 1319-1330.

Emery, K.O. and Uchupi, E., 1984. The geology of the Atlantic Ocean. New York, Springer-Verlag, $1050 \mathrm{pp}$.

Emmermann, R. and Puchelt, H., 1980. Major and trace element chemistry of basalts from Holes 417D and 418A, Deep Sea Drilling Project Legs 51-53. In Donnelly, T., et al., Initial Reports of the DSDP, v. 51, 52, 53, Part 2: Washington (U.S. Government Printing Office), p. 987-1000.

Flower, M.F.J. and Bryan, W.B., 1980. Deep Sea Drilling Project Sites 417 and 418: A petrogenetic synthesis. In Donnelly, T., et al., Initial Reports of the DSDP, v. 51, 52, 53, Part 2: Washington (U.S. Government Printing Office), p. 1557-1562.

Flower, M.F.J., Ohnmacht, W., Robinson, P.T., Marriner, G., and Schmincke, H.-U, 1980a. Lithologic and chemical stratigraphy at Deep Sea Drilling Project sites 417 and 418. In Donnelly, T., et al., Initial Reports of the DSDP, v. 51, 52, 53, Part 2: Washington (U.S. Government Printing Office), p. 939-956.

Flower, M.F.J., Pritchard, R.G., and Puchelt, 1980b. Variation in single cooling units at Deep Sea Drilling Project Hole 418A: effects of alteration and phenocryst redistribution. In Donnelly, T., et al., Initial Reports of the DSDP, v. 51, 52, 53, Part 2: Washington (U.S. Government Printing Office), p. 1021-1038.

Flower, M.F.J. and Robinson, P.T., 1981a. Basement drilling in the western Atlantic Ocean. 1. Magma fractionation and its relation to eruptive chronology. J. Geophys. Res., v. 86, p. 6273-6298.

Flower, M.F.J. and Robinson, P.T., 1981b. Basement drilling in the western Atlantic Ocean. 2. A synthesis of construction processes at the Cretaceous ridge axis. J. Geophys. Res., v. 86, p. 6299-6309.

Foss, G.N. and Knapp, R.R., 1980. Operations resumes part V, Leg 45 through Leg 54. Deep Sea Drilling Project Technical Report No. 10, Scripps Institute of Oceanography, La Jolla, Ca.

Foss, G.N. and Thompson, P.G., 1988. Ocean Drilling Program Operations Report - Leg 102. Texas A \& M University, Bryan, Tx.

Friedrichsen, H. and Hoernes, S., 1980. Oxygen and hydrogen isotope exchange reactions between sea water and oceanic basalts from Legs 51 through 53. In 
Donnelly, T., et al., Initial Reports of the DSDP, v. 51, 52, 53, Part 2: Washington (U.S. Government Printing Office), p. 1177-1182.

Fuglister, F.C., 1960. Atlantic Ocean Atlas of temperature and salinity profiles and data from the International Geophysical Year of 1957-1958. Woods Hole Oceanographic Institution Atlas Series 1, p. 209.

Galson, D.A. and Von Herzen, R.P., 1981. A heat flow survey on anomaly M0 south of the Bermuda Rise. Earth Planet. Sci. Letts., v. 53, p. 296-306.

Gartner, S., 1980. Calcareous nannofossils, Deep Sea Drilling Project Holes 418A and 418B. In Donnelly, T., et al., Initial Reports of the DSDP, v. 51, 52, 53, Part 2: Washington (U.S. Government Printing Office), p. 815-821.

Genkin, A.D., Laputina, I.P., and Pertsev, N.N., 1980. Opaque minerals in basalts from Holes 417D and 418A. In Donnelly, T., et al., Initial Reports of the DSDP, v. 51, 52, 53, Part 2: Washington (U.S. Government Printing Office), p. 1431-1450.

Gieskes, J.M., Hart, S., and Peretsman, G., 1988. Borehole water studies, Hole 418A. In Salisbury, M.H., Scott, J.H., et al., Proc. ODP, Sci. Results, 102: College Station, TX (Ocean Drilling Program), 127-134.

Gieskes, J.M. and Reese, H., 1980. Interstitial water studies, legs 51-53. In Donnelly, T., et al., Initial Reports of the DSDP, v. 51, 52, 53, Part 2: Washington (U.S. Government Printing Office), p. 747-751.

Gitlin, E., 1985: Sulfide remobilization during low temperature alteration of seafloor basalt. Geochim. Cosmochim. Acta, v. 49, p. 1567-1579.

Hamano, Y., 1980. Physical properties of basalts from Holes 417D and 418A. In Donnelly, T., et al., Initial Reports of the DSDP, v. 51, 52, 53, Part 2: Washington (U.S. Government Printing Office), p. 1457-1466.

Hamano, Y., Nishitani, T., and Kono, M., 1980. Magnetic properties of basalt samples from Deep Sea Drilling Project Holes 417D and 418A. In Donnelly, T., et al., Initial Reports of the DSDP, v. 51, 52, 53, Part 2: Washington (U.S. Government Printing Office), p. 1391-1405.

Harland, W.B., Cox, A.V., Llewellyn, P.G., Pickton, C.A.G., Smith., A.G. and Walters, R., 1982. A geologic time scale. Cambridge, Cambridge University Press, p. 128.

Hart, S.R. and Staudigel, H., 1978. Oceanic crust: age of hydrothermal alteration. Geophy. Res. Lett., v. 5, p. 1009-1012.

Hart, S.R. and Staudigel, H., 1980. Ocean crust-sea water interaction: Sites 417 and 418. In Donnelly, T., et al., Initial Reports of the DSDP, v. 51, 52, 53, Part 2: Washington (U.S. Government Printing Office), p. 1169-1176.

Hart, S.R. and Staudigel, H., 1982. The control of alkalies and uranium is seawater by ocean crust alteration. Earth Planet. Sci. Lett., v. 58, p. 202-212.

Hochuli, P. and Kelts, K., 1980. Palynology of middle Cretaceous black clay facies from Deep Sea Drilling Project Sites 417 and 418 of the western north Atlantic. In Donnelly, 
T., et al., Initial Reports of the DSDP, v. 51, 52, 53, Part 2: Washington (U.S. Government Printing Office), p. 897-935.

Holmes, M.A., 1988. Evidence for continuous and discontinuous alteration in DSDP Hole $418 \mathrm{~A}$ basalts and its significance to natural gamma-ray log readings. In Salisbury, M.H., Scott, J.H., et al., Proc. ODP, Sci. Results, 102: College Station, TX (Ocean Drilling Program), 135-151.

Honnorez, J., 1981. The aging of the oceanic crust at low temperature. In C. Emiliani (ed.), The sea, v. 7, The oceanic lithosphere, New York, John Wiley, p. 525-587.

Hoskins, H. and Groman, R.C., 1976. Informal report of surveys at IPOD Sites AT2.2 and AT2.3. Unpublished manuscript, p. 21.

Humphris, S.E., Thompson, R.N., and Marriner, G.F., 1980. The mineralogy and geochemistry of basalt weathering, Holes 417A and 418A. In Donnelly, T., et al., Initial Reports of the DSDP, v. 51, 52, 53, Part 2: Washington (U.S. Government Printing Office), p. 1201-1217.

Javoy, M. and Fouillac, A.M., 1980. Stable isotope ratios in Deep Sea Drilling Project Leg 51 basalts. In Donnelly, T., et al., Initial Reports of the DSDP, v. 51, 52, 53, Part 2: Washington (U.S. Government Printing Office), p. 1153-1157.

Johnson, D.M., 1980a. Crack distribution in the upper oceanic crust and its effects upon seismic velocity, seismic structure, formation permeability, and fluid circulation. In Donnelly, T., et al., Initial Reports of the DSDP, v. 51, 52, 53, Part 2: Washington (U.S. Government Printing Office), p. 1479-1490.

Johnson, D.M., 1980b. Fluid permeability of oceanic basalts. In Donnelly, T., et al., Initial Reports of the DSDP, v. 51, 52, 53, Part 2: Washington (U.S. Government Printing Office), p. 1473-1477.

Joron, J.L., Bollinger, C., Quisefit, J.P., Bougault, H., and Treuil, M., 1980. Trace elements in cretaceous basalts at $25^{\circ} \mathrm{N}$ in the Atlantic Ocean: alteration mantle compositions and magmatic processes. In Donnelly, T., et al., Initial Reports of the DSDP, v. 51, 52, 53, Part 2: Washington (U.S. Government Printing Office), p. 1087-1098.

Juteau, T., Noack, Y., Whitechurch, H., and Courtois, C., 1980. Mineralogy and geochemistry of alteration products in Holes 417A and 417D basement samples (Deep Sea Drilling Project Leg 51). In Donnelly, T., et al., Initial Reports of the DSDP, v. 51, 52, 53, Part 2: Washington (U.S. Government Printing Office), p. 1273-1297.

Kelts, K. and Giovanoli, G., 1980. Paleomagnetic directions from lower cretaceous interpillow limestones, Deep Sea Drilling Project Leg 51, Hole 417D, Bermuda Rise. In Donnelly, T., et al., Initial Reports of the DSDP, v. 51, 52, 53, Part 2: Washington (U.S. Government Printing Office), p. 1429-1430.

Kent, D.V. and Gradstein, F.M., 1985. A Cretaceous and Jurassic geochronology. Geol. Soc. Amer. Bull., v. 96, p. 1419-1427.

Klitgord, K.D. and Schouten, H., 1986. Plate kinematics of the central Atlantic. In P.R. Vogt and B.E. Tucholke (eds.), The geology of North America, v. M, The western North Atlantic region. Geol. Soc. Amer., p. 351-378. 
Kozarek, R.J. and Orr, W.N., 1980. Ichthyoliths, Legs 51 through 53. In Donnelly, T., et al., Initial Reports of the DSDP, v. 51, 52, 53, Part 2: Washington (U.S.

Government Printing Office), p. 857-895.

Larson, R.L. and Hilde, T.W.C., 1975. A revised time scale of magnetic anomalies for the Early Cretaceous and Late Jurassic. J. Geophys. Res., v. 80, p. 2586-2594.

Lawrence, James R., 1980. Temperatures of formation of calcite veins in the basalts from Deep Sea Drilling Project Holes 417A and 417D. In Donnelly, T., et al., Initial Reports of the DSDP, v. 51, 52, 53, Part 2: Washington (U.S. Government Printing Office), p. 1183-1184.

Legrand, J., Echardour, A., Floc'h, H., Floury, L., Gieskes, J., Harmegnies, F., Loaec, G., Pozzi, J.-P., Raer, Y. and Stephen, R.A., in press. CAMPAGNE FARE: Wireline re-entry of DSDP Hole 396B using the NADIA system. Transactions, American Geophysical Union.

Levi, S., 1980. Paleomagnetism and some magnetic properties of basalts fro the Bermuda Triangle. In Donnelly, T., et al., Initial Reports of the DSDP, v. 51, 52, 53, Part 2: Washington (U.S. Government Printing Office), p. 1363-1378.

Levi, S., Bleil, U., Smith, B.M., and Rigotti, P., 1980. Compilation of paleomagnetic and rock magnetic results of basalt samples from Deep Sea Drilling Project Legs 51, 52, and 53. In Donnelly, T., et al., Initial Reports of the DSDP, v. 51, 52, 53, Part 2: Washington (U.S. Government Printing Office), p. 1337-1350.

McKenzie, J.A. and Kelts, K.R., 1980. A study of interpillow limestones from the MZero anomaly, Deep Sea Drilling Project, Leg 51, Hole 417D. In Donnelly, T., et al., Initial Reports of the DSDP, v. 51, 52, 53, Part 2: Washington (U.S. Government Printing Office), p. 753-766.

McWilliams, J.C., et al., 1983. The local dynamics of eddies in the western North Atlantic. In A.R. Robinson (ed.) Eddies in Marine Science, Berlin, Springer-Verlag., p. $92-113$.

Mann, U. and Muller, G., 1980. X-ray mineralogy of Deep Sea Drilling Project Legs 51 through 53, western North Atlantic. In Donnelly, T., et al., Initial Reports of the $D S D P$, v. 51, 52, 53, Part 2: Washington (U.S. Government Printing Office), p. 721-729.

Mathez, E.A., 1980. Sulfide relations in Hole 418A flows and sulfur contents of glasses. In Donnelly, T., et al., Initial Reports of the DSDP, v. 51, 52, 53, Part 2:

Washington (U.S. Government Printing Office), p. 1069-1085.

Mevel, C., 1980. Mineralogy and chemistry of secondary phases in low temperature altered basalts from Deep Sea Drilling Project Legs 51, 52, and 53. In Donnelly, T., et al., Initial Reports of the DSDP, v. 51, 52, 53, Part 2: Washington (U.S. Government Printing Office), p. 1299-1317.

Miles, G.A. and Orr, W.N., 1980. Planktonic foraminifers from the Bermuda Rise, Deep Sea Drilling Project Legs 51, 52, and 53. In Donnelly, T., et al., Initial Reports of the DSDP, v. 51, 52, 53, Part 2: Washington (U.S. Government Printing Office), p. 791-813. 
Mithal, R., 1986. Evidence for a basal low velocity zone in oceanic crust, and new methods of phase analysis and external inversion. Unpublished Ph.D. Thesis, Columbia University.

MODE-1 Group, 1978. The Mid-Ocean Dynamics Experiment. Deep-Sea Res. 25, p. $859-901$.

Moos, D., 1988. Elastic properties of 110-Ma oceanic crust from sonic full waveforms in DSDP Hole 418A. In Salisbury, M.H., Scott, J.H., et al., Proc. ODP, Sci. Results, 102: College Station, TX (Ocean Drilling Program), 49-62.

Mountain, G.S., Driscoll, N.W., and Miller, K.G., 1985. Cenozoic seismic straatigraphy of the SW Bermuda Rise. Geol. Soc. Amer. Annual Meeting, Program with Abstracts, p. 670 .

Muehlenbachs, K., 1980. The alteration and aging of the basaltic layer of sea floor: oxygen isotope evidence from DSDP/IPOD Legs 51, 52, 53. In Donnelly, T., et al., Initial Reports of the DSDP, v. 51, 52, 53, Part 2: Washington (U.S. Government Printing Office), p. 1159-1167.

Mutter, J.C., and North Atlantic Transect (NAT) Study Group, 1985, Multichannel seismic images of the oceanic crust's internal structure: evidence for a magma chamber beneath the Mesozoic Mid-Atlantic Ridge. Geology, v. 13, p. 629-632.

NAT Study Group, 1985. North Atlantic Transect: a wise-aperture, two-ship multichannel seismic investigation of the oceanic crust. J. Geophys. Res., v. 90, p. 10321-10341.

Owens, W.B., Richardson, P.L., Schmitz, W.J., Rossby, H.T., and Webb, D.C., 1988. Nine-year trajectory of a SOFAR float in the southwestern North Atlantic. Deep-Sea Res., $\underline{35}$, p. 1851-1857.

Ozima, M., Kaneoka, I., and Yanagisawa, M., 1980. ${ }^{40} \mathrm{Ar}-{ }^{39} \mathrm{Ar}$ geochronological studies of drilled basalts from Leg 51 and Leg 51. In Donnelly, T., et al., Initial Reports of the $D S D P$, v. 51, 52, 53, Part 2: Washington (U.S. Government Printing Office), p. $1127-1128$.

Parsons, B. and Sclater, J.G., 1977. An analysis of the variation of ocean floor bathymetry and heat flow with age. J. Geophys. Res., v. 82, p. 803-827.

Pertsev, N.N. and Rusinov, V.L., 1980. Mineral assemblages and processes of alterations in basalts at Deep Sea Drilling Project Sites 417 and 418. In Donnelly, T., et al., Initial Reports of the DSDP, v. 51, 52, 53, Part 2: Washington (U.S. Government Printing Office), p. 1219-1242.

Plasse, D., 1980. Opaque mineralogy of altered basalts from Hole 417A of IPOD Leg 51. In Donnelly, T., et al., Initial Reports of the DSDP, v. 51, 52, 53, Part 2: Washington (U.S. Government Printing Office), p. 1407-1409.

Pritchard, R.G., 1980. Alterations of basalts from Deep Sea Drilling Project Legs 51, 52, and 53, Holes 417A and 418A. In Donnelly, T., et al., Initial Reports of the DSDP, v. 51, 52, 53, Part 2: Washington (U.S. Government Printing Office), p. 1185-1199. 
Puchelt, H. and Hubberten, H.-W., 1980. Preliminary results of sulfur isotope investigations on Deep Sea Drilling Project cores from Legs 52 and 53. In Donnelly, T., et al., Initial Reports of the DSDP, v. 51, 52, 53, Part 2: Washington (U.S. Government Printing Office), p. 1145-1148.

Purdy, G.M., 1983. the seismic structure of 140 m.y. old crust in the western central Atlantic Ocean. Geophys. J.R. Astr. Soc., v. 72, p. 115-137.

Purdy, G.M., Ewing, J.I., and Bryan, G.M., 1980. A deep-towed hydrophone seismic reflection survey around IPOD Sites 417 and 418. Marine Geology, v. 35, p. 1-19.

Purdy, G.M. and Ewing, J.E., 1986. Seismic structure of the oceanic crust. In P.R. Vogt and B.E. Tucholke (eds.), The geology of North America, v. M, The western North Atlantic region. Geol. Soc. Amer., p. 313-330.

Rabinowitz, P.D., Hoskins, H., and Asquith, S.M., 1980. Geophysical site survey results near Deep Sea Drilling Project Sites 417 and 418 in the central Atlantic Ocean. In Donnelly, T., et al., Initial Reports of the DSDP, v. 51, 52, 53, Part 1: Washington (U.S. Government Printing Office), p. 629.

Rabinowitz, P.D. and Jung, W-Y, 1986. Gravity anomalies in the western North Atlantic Ocean. In: Vogt, P.R. and Tucholke, B.E. (eds.), The geology of North America, vol. M, The western North Atlantic region, p. 205-214.

Reid, J.L., 1978. On the mid-depth circulation and salinity field in the North Atlantic Ocean. J. Geophy. Res. $\underline{83}$, p. 5063-5067.

Rice, S., Langmuir, C.H., Bender, J.F., Hanson, G.N., Bence, A.E., and Taylor, S.R., 1980. Basalts from Deep Sea Drilling Project Holes 417A and 417D, fractionated melts of a light rare-earth depleted source. In Donnelly, T., et al., Initial Reports of the $D S D P$, v. 51, 52, 53, Part 2: Washington (U.S. Government Printing Office), p. $1099-1111$.

Richardson, S.H., Hart, S.R., and Staudigel, H., 1980. Vein mineral ages of old oceanic crust. J. Geophy. Res., v. 85, p. 7195-7200.

Richards, A.F. and Fager, E., 1980. Water content and Atterberg limits of sediments at Deep sea Drilling Project Holes 417A and 418A, Legs 51 and 52, west Atlantic Ocean. In Donnelly, T., et al., Initial Reports of the DSDP, v. 51, 52, 53, Part 2: Washington (U.S. Government Printing Office), p. 1453-1455.

Riser, S.C. and Rossby, H.T., 1983. Quasi-Lagrangian structure and variability of the subtropical western North Atlantic circulation. J. Mar. Res. $\underline{41}$, p. 127-162.

Robinson, P.T., Flower, M.F.J., Swanson, D.A., and Staudigel, H., 1980. Lithology and eruptive stratigraphy of cretaceous oceanic crust, western Atlantic Ocean. In Donnelly, T., et al., Initial Reports of the DSDP, v. 51, 52, 53, Part 2: Washington (U.S. Government Printing Office), p. 1535-1555.

Rossby, H.T., Riser, S.C., and Mariano, A.J., 1983. The western North Atlantic - a Lagrangian viewpoint. In A.R. Robinson (ed.) Eddies in Marine Science, Berlin, Springer-Verlag., p. 66-91. 
Rusinov, V. and Kelts, K., 1980. X-ray diffraction of some samples for clay mineralogy from site 417, Deep Sea Drilling Project Leg 51, western North Atlantic. In Donnelly, T., et al., Initial Reports of the DSDP, v. 51, 52, 53, Part 2: Washington (U.S. Government Printing Office), p. 731-736.

Rusinov, V.L., Laputina, I.P., Muravitskaja, G.N., Zvjagin, B.B., and Gradusov, B.P., 1980a. Clay minerals in basalts from Deep sea Drilling Project Sites 417 and 418. In Donnelly, T., et al., Initial Reports of the DSDP, v. 51, 52, 53, Part 2: Washington (U.S. Government Printing Office), p. 1265-1271.

Rusinov, V.L., Pertsev, N.N., Arakeljanz, and Nosik, L.P., 1980b. Some isotope relations in basalts from Deep sea Drilling Project holes 417A, 417D, and 418A. In Donnelly, T., et al., Initial Reports of the DSDP, v. 51, 52, 53, Part 2: Washington (U.S. Government Printing Office), p. 1149-1151.

Salisbury, M.H., Scott, J.H., Auroux, C., Becker, K., Bosum, W., Broglia, C., Carlson, R., Christensen, N.I., Fisher, A., Gieskes, J., Holmes, M.A., Hoskins, H., Moos, D., Stephen, R., and Wilkens, R., 1988. Old oceanic crust: synthesis of logging, laboratory, and seismic data from Leg 102. In Salisbury, M.H., Scott, J.H., et al., Proc. ODP, Sci. Results, 102: College Station, TX (Ocean Drilling Program), 155-180.

Salisbury, M.H., Donnelly, T.W., and Francheteau, J., 1980a. Geophysical logging in Deep Sea Drilling Project Hole 417D. In Donnelly, T., et al., Initial Reports of the $D S D P$, v. 51, 52, 53, Part 1: Washington (U.S. Government Printing Office), p. 705713.

Salisbury, M.H., Stephen, R., Christensen, N.I., Francheteau, J., Hamano, Y., Hobart, M., and Johnson, D., 1980b. The physical state of the upper levels of cretaceous oceanic crust from the results of logging, laboratory studies, and the oblique seismic experiment at Deep Sea Drilling Project Sites 417 and 418. In Donnelly, T., et al., Initial Reports of the DSDP, v. 51, 52, 53, Part 2: Washington (U.S. Government Printing Office), p. 1579-1597.

Salisbury, M.H., Scott, J.H., Aurous, C.A., et al., 1986. Proc., Init. Repts. (Part A), Ocean Drilling Program, v. 102.

Scarfe, C.M., 1980. Secondary minerals in some basaltic rocks from Deep Sea Drilling Project Legs 52 and 53, Hole 418A. In Donnelly, T., et al., Initial Reports of the $D S D P$, v. 51, 52, 53, Part 2: Washington (U.S. Government Printing Office), p. 1243-1251.

Scheidegger, K.F. and Stakes, D.S., 1980. X-ray diffraction and chemical study of secondary minerals from Deep Sea Drilling Project Leg 51, Holes 417A and 417D. In Donnelly, T., et al., Initial Reports of the DSDP, v. 51, 52, 53, Part 2: Washington (U.S. Government Printing Office), p. 1253-1263.

Schmitz, W.J., 1976. Observations of a new abyssal current at the western foot of the Bermuda Rise. Geophys. Res. Letters, $\underline{3}$, p. 371-372.

Schmitz, W.J., 1989. The MODE site revisited. J. Mar. Res. 45, p. 131-151. 
Schouten, H. and Klitgord, K.D., 1977. Map showing Mesozoic magnetic anomalies, western North Atlantic. U.S. Geological Surv. Misc. Field Studies Map, MF 915, Scale 1:2,000,000.

Schouten, H., and Klitgord, K.D., 1982. The memory of the accreting plate boundary and the continuity of fracture zones. Earth Planet. Sci. Lett., v. 59, p. 255-266.

Schouten, H. and White, R.S., 1980. Zero offset fracture zones. Geology, v. 8, p. 175-179.

Senske, D.A., and Stephen, R.A., 1988. A seismic-reflection survey of DSDP Sites 417 and 418. In Salisbury, M.H., Scott, J.H., et al., Proc. ODP, Sci. Results, 102: College Station, TX (Ocean Drilling Program), 3-17.

Shearer, P.M., and Orcutt, J.A., 1987. Surface and near-surface effects on seismic waves - theory and borehole seismometer results. Bull. Seism. Soc. Amer., v. 77, p. $1168-1196$

Shimizu, H., Masuda, A., and Ui, T., 1980. Determination of rare-earth elements in Leg 51, Site 417 samples. In Donnelly, T., et al., Initial Reports of the DSDP, v. 51, 52, 53, Part 2: Washington (U.S. Government Printing Office), p. 1113-1120.

Shipboard Scientific Party, 1986. Site 418: Bermuda Rise. In: Salisbury, M.H., Scott, J.H., et al., Proc. ODP, Sci. Results, 102: College Station, TX (Ocean Drilling Program), p. 95-235.

Siesser, W.G., 1980. Calcareous Nannofossils: Legs 51 and 52 of the Deep Sea Drilling Project. In Donnelly, T., et al., Initial Reports of the DSDP, v. 51, 52, 53, Part 2: Washington (U.S. Government Printing Office), p. 823-845.

Sinton, J.M. and Byerly, G.R., 1980. Mineral compositions and crystallization trends in Deep Sea Drilling Project Holes 417D and 418A. In Donnelly, T., et al., Initial Reports of the DSDP, v. 51, 52, 53, Part 2: Washington (U.S. Government Printing Office), p. 1039-1054.

Smith, B.M. and Bleil, U., 1980. Rock magnetism of basement rocks, Deep Sea Drilling Project Site 417. In Donnelly, T., et al., Initial Reports of the DSDP, v. 51, 52, 53, Part 2: Washington (U.S. Government Printing Office), p. 1379-1389.

Staudigel H. and Bryan, W.B., 1981. Contrasted glass-whole rock compositions and phenocryst re-distribution, IPOD Sites 417 and 418. Contrib. Mineral. Petrol., v. 78, p. $255-262$.

Staudigel, H., Bryan, W.B., and Thompson, G., 1980a. Chemical variation in glasswhole rock pairs from individual cooling units in Holes 417D and 418A. In Donnelly, T., et al., Initial Reports of the DSDP, v. 51, 52, 53, Part 2: Washington (U.S. Government Printing Office), p. 977-986.

Staudigel, H., Frey, F.A., and Hart, S.R., 1980b. Incompatible trace-element geochemistry and $87 / 86 \mathrm{Sr}$ in basalts and corresponding glasses and palagonites. In Donnelly, T., et al., Initial Reports of the DSDP, v. 51, 52, 53, Part 2: Washington (U.S. Government Printing Office), p. 1137-1144. 
Staudigel, H., Hart, S.R., and Richardson, S.H., 1981. Alteration of the oceanic crust: processes and timing. Earth Planet. Sci. Lett., v. 52, p. 311-327.

Staudigel, H. and Hart, S.R., 1983. Alteration of basaltic glass: mechanisms and significance for the oceanic crust-seawater budget. Geoch. Cosmoch. Acta, v. 47, p. 337-350.

Stephen, R.A., Louden, K.E., and Matthews, D.H., 1980a. The oblique seismic experiment on Deep Sea Drilling Project Leg 52. In Donnelly, T., et al., Initial Reports of the DSDP., v. 51, 52, 53, Part 2: Washington (U.S. Government Printing Office), p. 675-704.

Stephen, R.A., Louden, K.E., and Mathews, D.H., 1980b. The oblique seismic experiment on DSDP Leg 52. Geophys. J.R. Astr. Soc., v. 60, p. 289-300.

Stephen, R.A. and Harding, A.J., 1983. Travel time analysis of borehole seismic data. J. Geophys. Res., v. 88, p. 8289-8298.

Stephen, R.A., Swift, S.A., and Bolmer, S.T., 1987. Ambient noise analysis and finite difference modelling of VLF borehole seismic data. WHOI Tech. Memo. No. 4-87, $35 \mathrm{p}$.

Storms, M.A. and Gerken, J.H., 1983. Reentry Cone Multiple Casing hanger systems. Deep Sea Drilling Project Technical Report No. 13, Scripps Institution of Oceanography, La Jolla, Ca.

Storzer, D. and Selo, M., 1980. Fission track age of magnetic anomaly $M$-zero and some aspects of sea-water weathering. In Donnelly, T., et al., Initial Reports of the DSDP, v. 51, 52, 53, Part 2: Washington (U.S. Government Printing Office), p. 1129-1133.

Swift, S.A. and Stephen, R.A., in press. Lateral heterogeneity in the seismic structure of upper oceanic crust, western North Atlantic. J. Geophys. Res.

Swift, S.A., Stephen, R.A., and Hoskins, H., 1988. structure of upper oceanic crust from an oblique seismic experiment at Hole 418A, western North Atlantic. In Salisbury, M.H., Scott, J.H., et al., Proc. ODP, Sci. Results, 102: College Station, TX (Ocean Drilling Program), 97-124.

Takaoka, N. and Nagao, K., 1980. Rare-gas studies of cretaceous deep-sea basalts. In Donnelly, T., et al., Initial Reports of the DSDP, v. 51, 52, 53, Part 2: Washington (U.S. Government Printing Office), p. 1121-1126.

Thompson, G., 1983. Hydrothermal fluxes in the ocean. In Chemical oceanography, J.P. Riley and R. Chester (eds.), London, Academic Press, v. 8, p. 272-337.

Thompson, R.N., 1980. Major-element chemistry of basaltic glasses in Hole 418A lavas and a dyke: Deep Sea Drilling Project Legs 51 and 52. In Donnelly, T., et al., Initial Reports of the DSDP, v. 51, 52, 53, Part 2: Washington (U.S. Government Printing Office), p. 973-976.

Tucholke, B.E., Wright, W.R., and Hollister, C.D., 1973. Abyssal circulation over the Greater Antilles Outer Ridge. Deep Sea Res. 20, p. 973-995. 
Tucholke, B.E., 1979. Relationships between acoustic stratigraphy and lithostratigraphy in the western North Atlantic Basin. In: B.E. Tucholke, P.R. Vogt, et al., Init. Repts. DSDP, v. 43, Washington (U.S. Government Printing Office), p. 791-825.

Tucholke, B.E. and Vogt, P.R., 1979, Western North Atlantic: sedimentary evolution and aspects of tectonic history. In: B.E. Tucholke, P.R. Vogt, et al., Init. Repts. DSDP, v. 43, Washington (U.S. Government Printing Office), p. 791-825.

Tucholke, B.E. and Mountain, G.S., 1979. Seismic stratigraphy, lithostratigraphy and paleosedimentation patterns in the North Atlantic Basin. In: Talwani M., Hay, W., Ryan, W.B.F. (eds.), Deep drilling results in the Atlantic Ocean: continental margins and paleo environment. Amer. Geophys. Union, Maurice Ewing Series, v. 3, p. 5886.

Ui, T., Haramura, H., and Nagai, H., 1980. Major element chemistry and microprobe studies of basalts from Deep Sea Drilling Project Leg 51, Site 417. In Donnelly, T., et al., Initial Reports of the DSDP, v. 51, 52, 53, Part 2: Washington (U.S. Government Printing Office), p. 1001-1020.

White, R.S., 1984. Atlantic ocean crust: seismic structure of a slow-spreading ridge. In: I.G. Gass, S.J. Lippard, and A.W. Shelton (eds.), Ophiolites and oceanic lithosphere, Oxford, Blackwell, p. 101-111.

Wilkens, R., Schultz, D., and Carlson, R., 1988. Relationship of resistivity, velocity, and porosity for basalts from downhole well-logging measurements in Hole 418A. In Salisbury, M.H., Scott, J.H., et al., Proc. ODP, Sci. Results, 102: College Station, TX (Ocean Drilling Program), 69-75.

Worthington, L.V., 1976. On the North Atlantic circulation. Baltimore, The Johns Hopkins Univ. Press, v. 6., p. 110.

Worthington, L.V. and Wright, W.R., 1970. North Atlantic Ocean atlas of potential temperature and salinity in the deep water, including temperature, salinity and oxygen profiles from the Erika Dan cruise of 1962 . WHOI Atlas Series, 2, p. 58.

Wright, W.R. and Worthington, L.V., 1970. The water masses of the North Atlantic Ocean; a voluruetric census of temperature and salinity. Ser. Atlas Mar., Amer. Geog. Soc., v. 19, p. 8. 


\section{DOCUMENT LIBRARY}

July 5, 1989

Distribution List for Technical Report Exchange

Attn: Stella Sanchez-Wade

Documents Section

Scripps Institution of Oceanography

Library, Mail Code C-075C

La Jolla, CA 92093

Hancock Library of Biology \& Oceanography

Alan Hancock Laboratory

University of Southern California

University Park

Los Angeles, CA 90089-0371

Gifts \& Exchanges

Library

Bedford Institute of Oceanography

P.O. Box 1006

Dartmouth, NS, B2Y 4A2, CANADA

Office of the International

Ice Patrol

c/o Coast Guard R \& D Center

Avery Point

Groton, CT 06340

Library

Physical Oceanographic Laboratory

Nova University

8000 N. Ocean Drive

Dania, FL 33304

NOAA/NESDIS Miami Library Center

4301 Rickenbacker Causeway

Miami, FL 33149

Library

Skidaway Institute of Oceanography

P.O. Box 13687

Savannah, GA 31416

Institute of Geophysics

University of Hawaii

Library Room 252

2525 Correa Road

Honolulu, HI 96822

Library

Chesapeake Bay Institute

4800 Atwell Road

Shady Side, MD 20876

MIT Libraries

Serial Journal Room 14E-210

Cambridge, MA 02139
Director, Ralph M. Parsons Laboratory

Room 48-311

MIT

Cambridge, MA 02139

Marine Resources Information Center

Building E38-320

MIT

Cambridge, MA 02139

Library

Lamont-Doherty Geological

Observatory

Colombia University

Palisades, NY 10964

Library

Serials Department

Oregon State University

Corvallis, OR 97331

Pell Marine Science Library

University of Rhode Island

Narragansett Bay Campus

Narragansett, RI 02882

Working Collection

Texas A\&M University

Dept. of Oceanography

College Station, TX 77843

Library

Virginia Institute of Marine Science

Gloucester Point, VA 23062

Fisheries-Oceanography Library

151 Oceanography Teaching Bldg.

University of Washington

Seattle, WA 98195

Library

R.S.M.A.S.

University of Miami

4600 Rickenbacker Causeway

Miami, FL 33149

Maury Oceanographic Library

Naval Oceanographic Office

Stennis Space Center

NSTL, MS 39522-5001

Marine Sciences Collection

Mayaguez Campus Library

University of Puerto Rico

Mayagues, Puerto Rico 00708 



\begin{tabular}{|c|c|c|c|}
\hline $\begin{array}{l}\text { REPORT DOCUMENTATION } \\
\text { PAGE }\end{array}$ & $\begin{array}{l}\text { 1. REPORT NO. } \\
\text { WHOI-89-20 }\end{array}$ & 2. & 3. Recipient's Accession No. \\
\hline \multirow{2}{*}{\multicolumn{2}{|c|}{$\begin{array}{l}\text { 4. Title and Subtitle } \\
\text { Site Synthesis Report of DSBP Sites } 417 \text { and } 418\end{array}$}} & & $\begin{array}{r}\text { 5. Report Date } \\
\text { June } 1989 \\
\end{array}$ \\
\hline & & & 6. \\
\hline \multicolumn{2}{|c|}{$\begin{array}{l}\text { 7. Author(s) } \\
\text { S.A. Swift, S.T. Bolmer, and R.A. Stephen }\end{array}$} & & $\begin{array}{l}\text { 8. Performing Organization Rept. No. } \\
\text { WHOI-89-20 }\end{array}$ \\
\hline \multirow{2}{*}{\multicolumn{2}{|c|}{$\begin{array}{l}\text { 9. Performing Organization Name and Address } \\
\text { The Woods Hole Oceanographic Institution } \\
\text { Woods Hole, Massachusetts } 02543\end{array}$}} & & 10. Project/Task/Work Unit No. \\
\hline & & & $\begin{array}{l}\text { 11. Contract(C) or Grant(G) No. } \\
\text { (C) } \\
\text { (G) }\end{array}$ \\
\hline \multirow{3}{*}{\multicolumn{2}{|c|}{$\begin{array}{l}\text { 12. Sponsoring Organization Name and Address } \\
\text { The Johns Hopkins University, Applied Physics Laboratory }\end{array}$}} & & 13. Type of Report \& Period Covered \\
\hline & & & Technical Report \\
\hline & & & 14. \\
\hline
\end{tabular}

15. Supplementary Notes

This report should be cited as: Woods Hole Oceanog. Inst. Tech. Rept., WHOI-89-20.

16. Abstract (Limit: 200 words)

This document summarizes information relevent to planning, execution, and interpretation of results from a study of the interaction of sound in the $2-30 \mathrm{~Hz}$ band with deep ocean seafloor using sea-surface sources, seafloor receivers, and borehole seismometers emplaced by wireline re-entry at Deep Sea Drilling Project sites 417 and 418 in the western North Atlantic. We summarize published scientific results from borehole sampling of water, sediment, and rock, from wireline logging, and from borehole seismic experiments. We present new results from analysis of total power recorded by receivers clamped in basement during the borehole seismic experiment on DSDP Leg 102. We document non-drilling investigations of the site and the nature and location of re-entry cones and transponders. We describe the physical oceanography of the region and the speed of sound in water. We provide an extensive bibliography on published results from scientific investigations at 417/418. This document was completed prior to 1989 surveys of sites 417 and 418 .

17. Document Analysis a. Descriptors

1. Marine geology and geophysics

2. borehole seismic experiment

3. western North Atlantic drilling

b. Identifiers/Open-Ended Terms

c. COSATI Field/Group

18. Availability Statement

Approved for publication; distribution unlimited.

19. Security Class (This Report)

UNCLASSIFIED

20. Socurity Class (This Page)
21. No. of Pages 160 22. Price 